Andrews University

Digital Commons @ Andrews University

\title{
A Study of Nones in Brazil and the USA in Light of Secularization Theory with Missiological Implications
}

Jolive R. Chavez

Andrews University, jolive@andrews.edu

Follow this and additional works at: https://digitalcommons.andrews.edu/dissertations

Part of the Missions and World Christianity Commons

\section{Recommended Citation}

Chavez, Jolive R., "A Study of Nones in Brazil and the USA in Light of Secularization Theory with Missiological Implications" (2020). Dissertations. 1745.

https://digitalcommons.andrews.edu/dissertations/1745

https://dx.doi.org/10.32597/dissertations/1745

This Dissertation is brought to you for free and open access by the Graduate Research at Digital Commons @ Andrews University. It has been accepted for inclusion in Dissertations by an authorized administrator of Digital Commons@ Andrews University. For more information, please contact repository@andrews.edu. 


\begin{abstract}
A STUDY OF NONES IN BRAZIL AND THE USA IN LIGHT OF SECULARIZATION THEORY, WITH MISSIOLOGICAL IMPLICATIONS
\end{abstract}

by

Jolive R. Chaves

Adviser: Gorden R. Doss 


\title{
ABSTRACT OF GRADUATE STUDENT RESEARCH
}

Dissertation

\author{
Andrews University
}

Seventh-day Adventist Theological Seminary

\section{Title: $\quad$ A STUDY OF NONES IN BRAZIL AND THE USA IN LIGHT OF SECULARIZATION THEORY, WITH MISSIOLOGICAL IMPLICATIONS}

Name of researcher: Jolivê R. Chaves

Name and degree of faculty adviser: Gorden R. Doss, PhD

Date completed: November 2020

The growth of those who declare themselves to be Nones, or religiously

unaffiliated, in Brazil and the USA has been continuously higher than that of the general population. In Brazil, they are the third-largest group in the religious field, behind only Catholics, and Pentecostal evangelicals. In the USA, they are the second largest group, after Protestants as a whole. The Nones, in their diverse groups, are more represented among the youth in both cultures, and reflect the modern and postmodern influences of contemporary secularism, being a product of the process of changing human thought.

This work studies the Nones, in both countries, based on selected elements that characterize the theories of secularization used within the sociology of religion. In the absence of a direct biblical text related to the Nones, as they are a phenomenon much later than the biblical period, a suggested biblical framework for mission with the group 
was chosen based on biblical narratives describing the missio Dei among what the Bible calls foreigners.

In the fifth chapter, the study proposes eight areas considered sensitive for the missional relationship with the Nones in both Brazil and America: The Identity of God, The Bible as the Source of Truth, Institutionalized Religion, Need for Relationships and Community, The Social Role of Religion, Cross-Cultural Barriers, Cultural and Religious Plurality, and Mass Communication/Technology. Some of these can be considered critical, and others as an opportunity for mission. The characteristics of Nones related to each area were presented, and then, missiological and sociological principles were suggested to fill the gaps in the respective areas, forming a bridge of contact with the Nones. 
Andrews University

Seventh-day Adventist Theological Seminary

A STUDY OF NONES IN BRAZIL AND THE USA IN LIGHT OF SECULARIZATION THEORY, WITH MISSIOLOGICAL IMPLICATIONS

\author{
A Dissertation \\ Presented in Partial Fulfillment \\ of the Requirements for the Degree \\ Doctor of Philosophy
}

by

Jolivê R. Chaves

November 2020 


\title{
A STUDY OF NONES IN BRAZIL AND THE USA IN LIGHT OF SECULARIZATION THEORY, WITH MISSIOLOGICAL IMPLICATIONS
}

\author{
A Dissertation \\ Presented in Partial Fulfillment \\ of the Requirements for the Degree \\ Doctor of Philosophy
}

by

Jolive R. Chaves

APPROVAL BY THE COMMITTEE:

Faculty Adviser, Gorden R. Doss

Professor Emeritus of World Mission

Petr Cincala

Assistant Professor of World Mission

Wagner Kuhn

Professor of World Mission

Tevni Grajales

Professor of Research and Statistical Methodology

Wilbert Shenk, Professor Emeritus of Mission

History \& Contemporary Culture

Fuller Graduate School of Intercultural Studies
Director, Ph.D./Th.D. Programs

John W. Reeve

Dean, SDA Theological Seminary

Jiř́i Moskala

Date Approved 


\section{TABLE OF CONTENTS}

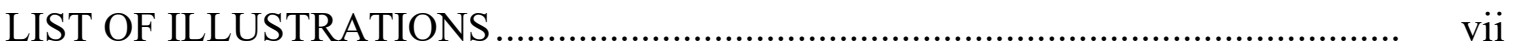

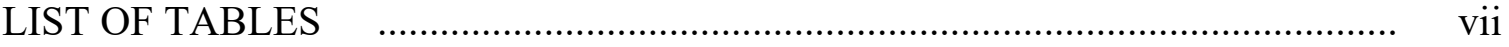

Chapter

I. INTRODUCTION ............................................................................... 1

Background to the Problem ................................................................. 1

Statement of the Problem .................................................................... 6

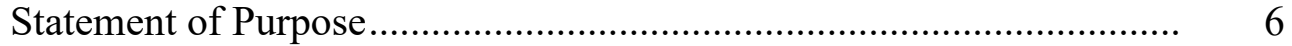

Research Questions ........................................................................ 6

Scope and Delimitations.............................................................. 7

Conceptual Framework .............................................................. 7

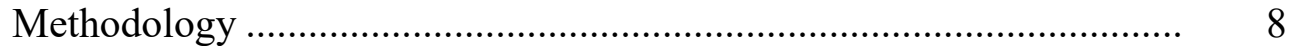

Chapter Outline ............................................................................. 9

II. SELECTED ELEMENTS THAT CHARACTERIZE THE THEORIES OF SECULARIZATION ........................................................................... 11

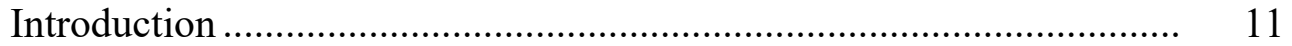

Sociology of Religion................................................................... 15

Elements of Secularization Theories of Weber and Followers....... 17

Max Weber (1864-1920) .............................................. 17

Bryan R. Wilson (1926-2004) ............................................ 22

Thomas Luckmann (1927-2016) ........................................... 27

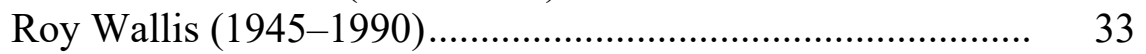

Summary of Weber and Followers ...................................... 37

Elements of Secularization Theories of Durkheim and Followers . $\quad 38$

Emile Durkheim (1858-1917) ............................................ 38

Rodney Stark (1934- ) and William Bainbridge (1940-)...... 46

Grace Davie (1946- )...................................................... 51

Laurence Iannaccone (1954- )............................................ 54

Summary of Durkheim and Followers.................................. 61

Elements of Secularization Theories of Independent Scholars....... 61

Peter Berger (1929-2017)...................................................... 61

Charles Taylor $(1931-)$...................................................... 67

Talal Asad (1932- ) ......................................................... $\quad 70$

Summary of Selected Independent Scholars.......................... 75

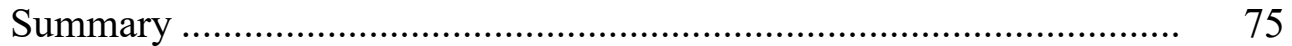


III. NONES IN BRAZIL AND THE UNITED STATES IN LIGHT OF THE SECULARIZATION THEORIES

Introduction ................................................................................ 78

Summary of Religious Scenario and Profile of Nones in Brazil.......... 79

Summary of Religious Scenario and Profile of Nones in the United

States

Category 1: Religious Disenchantment............................................. 90

Summary of the Topic............................................................ 90

Relating the Topic to the Nones in Brazil and the United States.... 91

Summary of Category 1 .............................................................. 99

Category 2: Weakening of the Public Influence of Religion ............... 99

Summary of the Topic.............................................................. 99

Relating the Topic to the Nones in Brazil and the United States.... 100

Summary of Category 2 ........................................................... 111

Category 3: Religious Pluralism in a Market Environment ................. 112

Summary of the Topic............................................................... 112

Relating the Topic to the Nones in Brazil and the United States.... 114

The Foundations of Religious Pluralism..................................... 115

Effects of Religious Pluralism .................................................. 119

Market Religiosity ............................................................. 120

Emphasis on Spiritualizing Religion ................................... 137

Summary of Category 3 ..................................................... 152

Category 4: The Changing and Permanent Nature of Religion ............ 155

Summary of the Topic.............................................................. 155

Relating the Topic to the Nones in Brazil and the United States.... 156

Summary of Category 4 .......................................................... 163

Category 5: The Contemporary Secular............................................ 164

Summary of the Topic................................................................. 164

Relating the Topic to the Nones in Brazil and the United States.... 165

Summary of Category 5 ...................................................... 167

Category 6: Influence of Technological Advances and Mass

Communication ...................................................................... 168

Summary of the Topic......................................................... 168

Relating the Topic to the Nones in Brazil and the United States.... 169

Summary of Category 6 .......................................................... 178

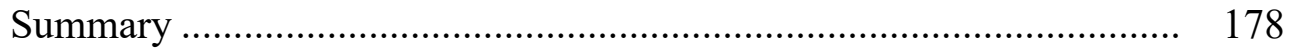

IV. BIBLICAL FRAMEWORK FOR MISSION AMONG NONES .............. 182

Introduction .............................................................................. 182

Principle 1: Mission Based on Relationships_An Action of Hesed .... 183

Hesed in the Ruth Narrative...................................................... 187

A Theology of Mission on Hesed Use in Ruth ........................... 188

Missiological Implications of Hesed to Nones ........................... 191

Summary of Principle 1 ............................................................ 192

Principle 2: Mission Based on the Saving Power of God .................... 192 
The Power Encounter ...................................................................... 193

Territorial Spirits ...................................................................... 195

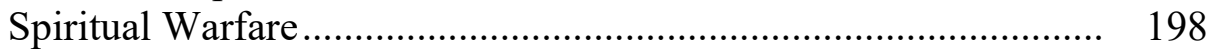

Mission Based on the Saving Power of God................................. 199

2 Kings 5:1-19 ................................................................... 200

The Manifestation of God in the Experience of Naaman ........ 201

The Manifestation of the Saving Power of God .................... 207

The Saving Power of God Applied to Nones................................. 208

Summary of Principle 2 ......................................................... 210

Principle 3: Mission Based on Biblical Instruction............................... 210

God-Fearers.................................................................... 211

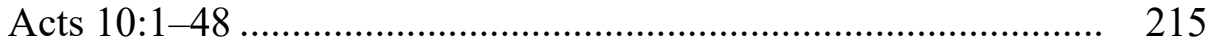

The Saving Power of God.................................................... 215

The Hesed Action ................................................................. 218

Mission Based on Biblical Instruction................................... 219

Missiological Implications of Biblical Instruction to Nones .......... 224

Summary of Principle 3 ........................................................... 226

Principle 4: Mission Based on Contextualization ................................ 227

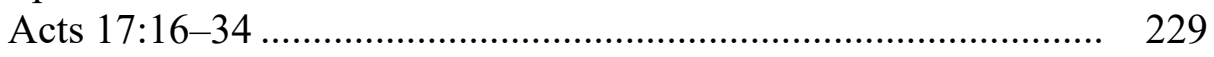

To the Unknown God......................................................... 229

Idolatry ……........................................................... 230

Stoicism and Epicureanism.................................................. 231

Mission Based on Contextualization ...................................... 232

Missiological Implications of Theological Contextualization to Nones 238

Summary of Principle 4 ......................................................... $\quad 240$

Summary …….................................................................... 241

V. CULTURAL AND MISSIOLOGICAL IMPLICATIONS ............................ 244

The Identity of God .................................................................... 246

Manifestation of God's Saving Power .......................................... 247

Manifestation of the "Energy of God".......................................... 247

Jesus as the Perfect Revelation of God ........................................ 251

The Bible as the Source of Truth ........................................................... 253

Institutionalized Religion ................................................................ 257

Need for Relationships and Community ............................................. 264

The Social Role of Religion .............................................................. 267

Cross-Cultural Barriers ................................................................... 269

Cultural and Religious Plurality ....................................................... $\quad 270$

Mass Communication/Technology .................................................. 273

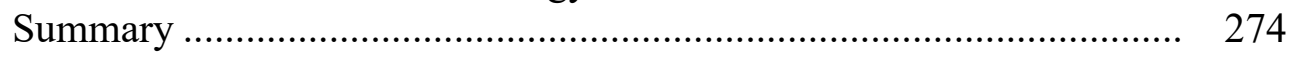

VI. SUMMARY, CONCLUSION, AND RECOMMENDATIONS .................. 277

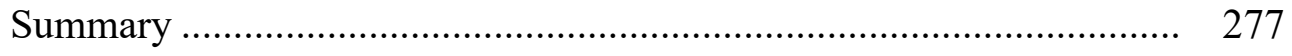




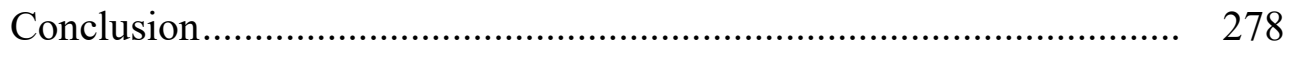

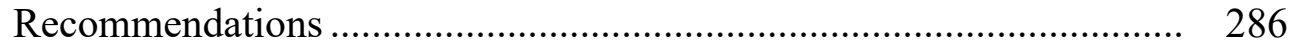

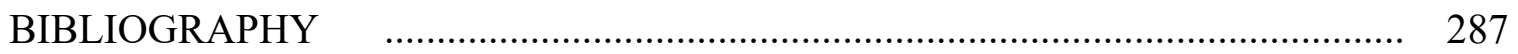




\section{LIST OF ILLUSTRATIONS}

1. Frequency of Attending Religious Services by Americans in \% ...................... 86

2. Religious Affiliation by Age in the US ....................................................... 88

3. Nature of Union in Brazil by Religion Compared with National Average in \%.. 93

4. Interfaith Marriage and Living with a Partner Among Religions in \%.............. 94

5. Percentage of Undetermined Among Evangelicals in the 2000-2010 Census ..... 128

6. Mixed-Religion Parents Raise Kids Less Religiously .................................. 133

7. Religious Switching: Nones Make Big Gains, Catholics Experience Big Losses

8. Increase of "Spiritual but Not Religious" Is Broad-Based .............................. 141

\section{LIST OF TABLES}

1. Religions by Population Percentage in Brazil from 1940-2010

2. Religions by Population Percentage in Brazil, August 1994 to December 2016-Nones Including Atheistic

3. Childhood and Current Religion in $\%$

4. Christians, Non-Christians, and Nones in the US in Three Moments in \%.........

5. Summary of the Mean Religious Identity of American Nones in $\%$

6. Spirituality of US Nones Who Believe in God in \%

7. Size and Projected Growth of Major Religious Groups in Latin America and the Caribbean, 2010-2050. 
8. Loss of Members Between 2000 and 2010 in Brazilian Main Churches

9. Nones across Generations

10. Many Protestant Denominational Families Lose More Adherents Than They Gain via Religious Switching

11. Most of Those Who Say They Are Spiritual but Not Religious Also Identify

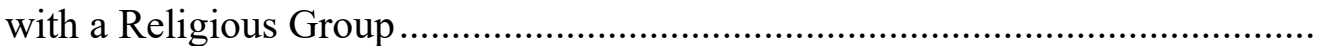

12. Rapid Growth in Number of Religious "Nones" Who Say Religion Is Not Important to Them

13. Sensitive Areas and Principles

14. Theoretical Conceptual Diagram 


\section{CHAPTER I}

\section{INTRODUCTION}

This dissertation is a study of "Nones" in Brazil and the United States, in the light of secularization theories, based on selected elements that characterize the theories. By seeking to understand the phenomenon of the Nones in both countries, the research aimed to facilitate a more effective mission strategy among this group.

\section{Background to the Problem}

The term Nones, in this work, will be used interchangeably with the term non-religious to refer to those who are religiously unaffiliated. This group is composed of atheists, agnostics, and those without religious identification. ${ }^{1}$ The Nones are a global people group with great significance for Christian mission, being somewhat smaller than the largest world religionsChristianity and Islam. ${ }^{2}$ The rise of the Nones in the United States is a growing phenomenon. In

\footnotetext{
${ }^{1}$ This definition is coherent with American and Brazilian scholars` position about the issue. See Pew Research Center, "Why America`s 'Nones' Don`t Identify with a Religion," August 8, 2018, https://www.pewresearch.org/fact-tank/2018/08/08/why-americas-nones-dont-identify-with-a-religion/. See also Instituto Brasileiro de Geografia e Estatística, Censo demográfico 2010: Características gerais da população, religião e pessoas com deficiencia (Rio de Janeiro: IBGE, 2012), https://biblioteca.ibge.gov.br/visualizacao/periodicos/94/cd_2010_religiao_deficiencia.pdf, table 1.4.1.

${ }^{2}$ One of every six people in the world identifies as non-religious. They are 16 percent of the population of the planet, about 1.2 billion people. Christians are the largest religious group, with 2.3 billion adherents and 31.2 percent of the world population. The second largest group is Muslims, with 1.8 billion followers, representing 24.1 percent of the population. See Pew Research Center, "Christians Remain World`s Largest Religious Group, but They Are Declining in Europe," April 5, 2017, https://www.pewresearch.org/fact-tank/2017/04/05/christiansremain-worlds-largest-religious-group-but-they-are-declining-in-europe/. Dividing the world into six large areas, non-religious represent the following percentages of the respective populations: Asia-Pacific 21.2 percent; Europe 18.2 percent; North America 17.1 percent; Latin America-Caribbean 7.7 percent; Sub-Saharan Africa 3.2 percent;
} 
1940 Nones were 5 percent of the population ${ }^{3}$; they remained below 10 percent from the 1970 s through the early 1990s, and then they began to rise noticeably in the 1990s, reaching 18 percent in $2010,{ }^{4} 19.6$ percent in $2012,{ }^{5}$ and 23 percent in $2014 .{ }^{6}$ Although Nones in the United States are present and growing in all generations, the millennial generation is the one with the highest percentage of Nones, at 36 percent. $^{7}$

Regarding the identity of Nones and their relationship with God, about 29 percent of them declare themselves atheists or agnostics, while 71 percent have no particular religious affiliation. Although 68 percent claim to believe in God, only 17 percent believe in God as described in the Bible, while 53 percent believe in a higher power or spiritual force, and 27 percent do not believe in God or a higher power. One major issue to the Nones is the relationship between religion and spirituality. While 37 percent say they are "spiritual but not religious" (SBNR), 42 percent claim to be neither spiritual nor religious. ${ }^{8}$

and Middle East-North Africa 0.6 percent. See Pew Research Center, "Religiously Unaffiliated," December 18, 2012, http://www.pewforum.org/2012/12/18/global-religious-landscape-unaffiliated/.

${ }^{3}$ James Emery White, The Rise of the Nones (Grand Rapids, MI: Baker Books, 2014), 17.

${ }^{4}$ Michael Hout and Claude S. Fischer, "Explaining Why More Americans Have No Religious Preference: Political Backlash and Generational Succession, 1987-2012," Sociological Science 1 (2014): 423-47, https:/www.sociologicalscience.com/download/volume\%201/october/SocSci_v1_423to447.pdf.

${ }^{5}$ Pew Research Center, "Nones on the Rise,” October 9, 2012, http://www.pewforum.org/2012/10/09/nones-on-the-rise/.

${ }^{6}$ Pew Research Center, "Religious Nones Are Not Only Growing, They’re Becoming More Secular," November 11, 2015, http:/www.pewresearch.org/fact-tank/2015/11/11/religious-nones-are-not-only-growingtheyre-becoming-more-secular/.

${ }^{7}$ Pew Research Center, "Millennials Increasingly Are Driving Growth of 'Nones,'” May 12, 2015 , http://www.pewresearch.org/fact-tank/2015/05/12/millennials-increasingly-are-driving-growth-of-nones/.

${ }^{8}$ See Pew Research Center, "Nones on the Rise'; Pew Research Center, "When Americans Say They Believe in God, What Do They Mean?," April 25, 2018, http://www.pewforum.org/2018/04/25/when-americanssay-they-believe-in-god-what-do-they-mean/. 
SBNR reflects a particular spiritual formulation, constructing personalized sets of beliefs and practices instead of following established dogmas, and defending a non-rational spiritual worldview. ${ }^{9}$ They see religion and spirituality as different things. Religion is a system of beliefs, practices, and rituals that establish a relationship between human beings and the transcendent and divine; spirituality is seen as a personal and individualized experience with the sacred, free of religion as a mediating factor. ${ }^{10}$ In other words, the institutional aspect of religion has been discredited for this group.

As in the United States, Nones in Brazil are a significant phenomenon. The country has the fourth highest percentage of Nones in South America, ${ }^{11}$ and the rise of this group has been dramatic, especially after the 1990s. In 1940, 0.2 percent of the Brazilian population declared themselves non-religious; this increased to 0.5 percent in 1950 and 0.8 percent in 1970 . By 1980, the percentage of non-religious citizens had doubled to 1.6 percent. The recent growth of this group has been astonishing: it reached 4.8 percent in 1990, 7.4 percent in 2000, and 8.04 percent in $2010 .^{12}$

\footnotetext{
${ }^{9}$ Courtney Miller, "Spiritual but Not Religious: Rethinking the Legal Definition of Religion," Virginia Law Review 102, no. 3 (2016): 833-94, http://www.jstor.org/stable/43923324.

${ }^{10}$ Pninit Russo-Netzer and Ofra Mayseless, "Spiritual Identity outside Institutional Religion: A Phenomenological Exploration," Identity 14, no. 1 (2014): 19-42, https://doi.org/10.1080/15283488.2013.858224.

${ }^{11}$ Uruguay, Chile, and Argentina occupied the three first positions in percentage of non-religious, while Paraguay is the most religious country in the region. In Uruguay, 37 percent of the population declared themselves non-religious, followed by Chile with 16 percent, Argentina with 11 percent, and Brazil 8.04 percent. In Paraguay only 1 percent of the population declared themselves non-religious. See complete list in Pew Research Center, "Religion in Latin America," November 13, 2014, http://www.pewforum.org/2014/11/13/religion-in-latin-america/.

${ }^{12}$ Instituto Brasileiro de Geografia e Estatística, "Religião: Séries históricas e estatísticas, população por religião; população presente e residente," accessed February 13, 2018, https://seriesestatisticas.ibge.gov.br/series.aspx?vcodigo $=$ POP60.
} 
Most non-religious people in Brazil are among the younger generations. In the year 2000, 60.1 percent of them were aged $0-29$, rising in 2010 to 65.5 percent, ${ }^{13}$ and they have the lowest average age of religious groups in the country (26 years). ${ }^{14}$ However, non-religious people are present in all age groups, tending to decrease only among those 80 or older. ${ }^{15}$

Regarding identity, non-religious people in Brazil are divided into three main groups: agnostics ( 0.8 percent), atheists ( 4 percent), and those without religion (95.2 percent). ${ }^{16}$ Scholars of religion in Brazil interpret this third group as people with no religious affiliation; many of them believe in God or a higher power, but cultivate a particular religious experience, separate from traditional institutions, declaring themselves "spiritual, but not religious."17

In both countries, Nones are critical of religious organizations and seek to keep their distance from them. They advocate the right to create individual belief systems and make a separation between spirituality and religion. Some of them have a syncretic view of religion and stand in favor of relativism and religious pluralism. The growth of Nones in both Brazil and the US presents a great challenge to the mission work of the Seventh-day Adventist Church and other Christians.

${ }^{13}$ Instituto Brasileiro de Geografia e Estatística, Censo demográfico 2010, table 14.

${ }^{14}$ Instituto Brasileiro de Geografia e Estatística, Censo demográfico 2010, figure 38.

${ }^{15}$ Instituto Brasileiro de Geografia e Estatística, Censo demográfico 2010, table 14.

${ }^{16}$ Instituto Brasileiro de Geografia e Estatística, Censo demográfico 2010, table 1.4.1.

${ }^{17}$ Denise S. Rodrigues, "Religiosos sem igreja: Um mergulho na categoria censitária dos sem religião," REVER (December 2007): 31-56, http://www.pucsp.br/rever/rv4_2007/t_rodrigues.pdf; Jose Alves C. Vieira, "Os sem religião: Dados para estimular a reflexão sobre o fenômeno," Horizonte 13, no. 37 (2015): 610-12, http://dx.doi.org/10.5752/P.2175-5841.2015v13n37p605. 
Since religion arises through primary social exchanges, ${ }^{18}$ there is always a close relationship between religion and society. Hence, the aim of the science of religion is to examine religion in its historical-social context. ${ }^{19}$ The theories of secularization are one concrete example of a social science perspective on religion. They are a set of ideas about how religion began losing its influence in societies in the Enlightenment period, beginning in Western Europe and spreading to the whole world. ${ }^{20}$

In general, sociologists of religion have seen the process of secularization as inevitable. But there is disagreement as to the outcome of this influence on religion. Some have argued that over time, religion will disappear, resulting in a society without religion. Others theorize that religion will not disappear, but will change its form of expression. Historically, predictions of the weakening of religion have been fulfilled in three respects: first, institutional religion has shifted from the center to the periphery of modern societies, while governments have become secular, lacking official religious identification. The second is the loss of religion's monopoly on the public worldview, which has passed from religious institutions to science. Finally, the symbols and signs of religious institutions continue to decline in relevance. ${ }^{21}$

However, the prediction of the disappearance of religion has not been fulfilled. Religion has not only persisted, but, in many cases, has grown and assumed a leading role in today's dynamic, globalized societies. Nevertheless, there has been a significant change in religious

\footnotetext{
${ }^{18}$ Rodney Stark and William Sims Bainbridge, The Future of Religion (Los Angeles, CA: University of California Press, 1985), 16-17.

${ }^{19}$ Bryan Wilson, Religion in Secular Society (Oxford: Oxford University, 2016), 14.

${ }^{20}$ Judith Fox, "Secularization," in Routledge Companion to the Study of Religion, ed. John R. Hinnells (New York: Routledge, 2010), 306.

${ }^{21}$ José de Jesús Legorreta Zepeda, "Secularização ou ressacralização? O debate sociológico contemporâneo sobre a teoria da secularização,” Revista Brasileira de Ciências Sociais 25, no. 73 (2010): 129-41.
} 
expression today. ${ }^{22}$ The Nones in the United States and Brazil who are open to spirituality but do not want a relationship with religious institutions are one example of this diverse way of expressing religion. Thus, the ideas and elements provided by secularization theories may help us to understand contemporary Nones and provide insights into how to work with them.

\section{Statement of the Problem}

The Nones currently constitute a newly evolving global people group with a growing significance that presents a new challenge for traditional ways of looking at the mission. Developing effective mission strategies for Nones is a great challenge because conventional approaches do not work with them. A theoretical base upon which to develop effective mission strategies has not been developed.

\section{Statement of Purpose}

The purpose of this research was to study the Nones in the United States and Brazil in light of the theories of secularization with missiological implications. An analysis from the sociology of religion perspective provided a conceptual basis for missiological insights and principles for working with Nones.

\section{Research Questions}

1. What are the worldviews, ${ }^{23}$ cultural characteristics, and causes of the None phenomenon in the United States and Brazil?

${ }^{22}$ Charles Taylor, A Secular Age (Cambridge, MA: Belknap Press, 2007), 437.

${ }^{23}$ Worldview is the way people read and understand the world, or how culture conceptualizes reality. It also refers to the presuppositions on which people act and give meaning to life. See Kleber de Oliveira Gonçalves, "A Critique of the Urban Mission of the Church in the Light of an Emerging Postmodern Condition" (PhD diss., Andrews University, 2005), 17. According to Kraft, worldview is "the central systematization of conceptions of reality to which the members of culture assent." Charles H. Kraft, Christianity in Culture: A Study in Dynamic Biblical Theologizing in Cross-Cultural Perspective (Maryknoll, NY: Orbis, 1979), 53. 
2. How do the theories of secularization shed light on the causes and features of the Nones?

3. What missiological principles can be drawn from the key biblical passages for mission among Nones?

4. What are the missiological implications of the findings of this study for mission work among the Nones?

\section{Scope and Delimitations}

The research included a study of the theories of secularization, as formulated by the sociology of religion - the branch of sociology that analyzes religion as a social phenomenon, and its influence on the individual and the community, and limited itself to examining Nones in the contexts of the United States and Brazil. ${ }^{24}$ This study did not involve field research into the worldview of Nones, but included a meta-analysis and summary of published research reports. The study did not provide the comparisons and contrasts of Nones in the broad range of cultural subgroups in both Brazil and the USA.

\section{Conceptual Framework}

The conceptual framework of this study followed the following parameters: First, the Missio Dei, or the idea that mission originates in God. From this perspective, this work presented biblical concepts that point to the divine mission mandate among the Nones. The second parameter was the social role of religion. Emile Durkheim said that religion would never lose its

\footnotetext{
${ }^{24}$ There are two main reasons why the researcher chose to study the Nones in the United States and Brazil. First, because his doctoral study is conducted in the US, where he has access to a wide range of information on the subject, and at the same time, he works in Brazil, where will he return after the conclusion of the studies. Therefore, it is convenient to include both countries in the study. Second, because to study the Nones in the context of both countries allow more broad information as it is possible to explore similarities and contrasts that characterize the group in both cultures.
} 
social significance, because society is the soul of religion, and religion has social causes. ${ }^{25}$ Thus, the theories of secularization were studied through the prism of the sociology of religion, taking as primary sources the writings of Max Weber (1864-1920), and Emile Durkheim (1858-1917). Both authors are considered the parents of this branch of sociology, and lived in the same period when the main theories that preached the virtual death of God were established.

The study considered the work of some disciples of Weber, such as Bryan Wilson (19262004), Thomas Luckmann (1927-2016), and Roy Wallis (1945-1990), and of Durkheim, such as Rodney Stark (1934- ), William Bainbridge (1940- ), Grace Davie (1946- ), and Laurence Iannaccone (1954- ), as well as that of three independent sociologists of religion: Peter Berger (1929-2017), Charles Taylor (1931- ), and Talal Asad (1932- ). The third parameter was the interaction between the main elements that characterize the theories of secularization and the Nones in United States and Brazil; the study aimed to understand this group in light of those theories.

\section{Methodology}

This research was a bibliographical study that followed the following pattern: biblical and missiological literature, sociology of religion, and research data on Nones, encompassing books, articles, dissertations, and online sources. 426.

${ }^{25}$ Emile Durkheim, The Elementary Forms of the Religious Life (New York: The Free Press, 1912), 421, 


\section{Chapter Outline}

This study is presented in six chapters. Chapter one introduced the study topic, outlined the background of the problem, and stated the problem, purpose, and research questions. Details of the scope, delimitations, and conceptual framework that guided the study were also presented.

Chapter two begins with a summary of the thinking of influential scholars in the period when modern ideology reached its culmination - the arrival of the Enlightenment (from the second half of the eighteenth century). They predicted cognitive progress and abandonment of faith, and attributed to science and technology the ability to transform the world and control the destiny of humanity. In this scenario, the sociology of religion established the so-called secularization theories, foreseeing religion's future under secular influence. The study covers the works of Max Weber and Emile Durkheim, considered the fathers of the sociology of religion, and seven of their disciples, as well as three independent scholars in that branch of sociology: Peter Berger, Charles Taylor, and Talal Asad. Twelve elements were identified that characterize the secularization theories of these authors.

Chapter three examines the Nones in Brazil and the United States in light of these twelve elements of secularization theories. The chapter begins with a summary of the religious scenario and profiles of the Nones in the cultures under study; then the Nones are analyzed based on six categories that group the twelve elements mentioned.

Chapter four presents a biblical framework for mission with the Nones. It describes the work of God and his representatives for the salvation of foreign people, as reported in four biblical narratives, two in the OT and two in the NT. The missiological principles found in these narratives shed light on cross-cultural mission efforts to reach contemporary groups of Nones in both cultures under study. 
Chapter five presents the study's cultural and missiological implications, proposing, based on the previous topics, a series of missiological principles for cross-cultural mission work among the Nones. Eight areas are considered critical or seen as an opportunity for a missional relationship: the identity of God, the Bible as the source of truth, institutional religion, relationship and community, the social role of religion, cross-cultural barriers, cultural and religious pluralism, and mass communication. For each of these areas, principles are suggested to serve as a bridge to get closer to the Nones.

A conclusion is offered in Chapter six. The chapter also provides recommendations for what can and should be done in the Christian effort to reach the Nones, especially in the Brazilian and American cultures under study. 


\section{CHAPTER II}

\section{SELECTED ELEMENTS THAT CHARACTERIZE}

\section{THE THEORIES OF SECULARIZATION}

\section{Introduction}

Theories of secularization are a set of ideas about how religion ${ }^{26}$ has lost its influence in societies with the spread of "modernity," ${ }^{27}$ beginning in Western Europe and extending to the whole world.$^{28}$ According to the Oxford English Dictionary, the term secular has two primary meanings. First, etymologically, the term comes from the Latin root saeculum, meaning "century" or "age." Second, secularization is "the process of removing the influence or power that religion has over something." This second concept is used by the sociology of religion to develop theories of secularization.

\footnotetext{
${ }^{26}$ According to Wallis and Bruce, there are functional and substantive definitions of religion. The functional definition identifies religion in terms of what it does. For example, religion can be that which answers fundamental issues of the human existential condition or provides solutions to ultimate human problems. In this case, religion does not include just relationship with the sacred, but also secular activities such as political ideologies and psychological therapies. The substantive definition identifies religion in terms of what it is. For example, religion can be a set of beliefs and actions from the point of view of the existence of supernatural beings or powers. See Roy Wallis and Steve Bruce, "Secularization: The Orthodox Model," in Religion and Modernization, ed. Steve Bruce (Oxford: Clarence Press, 1992), 9-10. The present research will use the substantive definition of religion, because it seems more appropriate to the nature of the work.

${ }^{27}$ Modernity is usually understood as the rupture with medieval thought, centered on religiosity, and the establishment of the autonomy of reason that shaped Western philosophy, culture, and societies from the sixteenth century. See Mayos Gonçal Solsona, "El problema sujeto-objeto en Descartes, prisma de la modernidad," Pensamiento: Revista de investigación e información filosófica 49, no. 193/195 (July-September 1993): 371-90, https://philpapers.org/rec/SOLEPS. See also Philip Sampson, Vinay Samuel, and Chris Sugden, "Introduction," in Faith and Modernity, ed. Philip Sampson, Vinay Samuel, and Chris Sugden (Oxford: Regnum, 1994), 7.

${ }^{28}$ See Fox, "Secularization,” 306.
} 
The culmination of modern thought occurred in the eighteenth century with the Enlightenment project, in which intellectuals defended reason as opposed to what they called fanaticism and superstition. ${ }^{29}$ This chapter examines theories of secularization from the perspective of the sociology of religion, but begins by describing the ideas of some philosophers of that period to contextualize the issue. In his essay "Religion within the Boundaries of Mere Reason," the Prussian philosopher Immanuel Kant (1724-1804) proposed a reinterpretation of traditional Christian doctrines such as sin, atonement, grace, and the kingdom of God through philosophy. He defended a possible union between the Christian faith and the religion of reason — an original disposition for good in human nature, such that human beings can and should create moral reform through rationality and the exercise of free will. ${ }^{30}$

Voltaire (1694-1778), whose real name was François-Marie d'Arouet, became the voice of the French Enlightenment. In his essay about toleration, printed in 1763, he stood up in defense of human liberty of thought and belief. ${ }^{31}$ According to him, civil power cannot exercise competence in relation to theological issues, and individual citizens have no right to interfere in the religious belief of others. Thus, Voltaire proposed and defended the novel theory that human beings are naturally free and equal, and possess fundamental rights that should be respected in civil society by rulers, whose role is not to intervene in these civil rights, but to protect them. Inspired by the English philosopher John Locke (1632-1704), who had written a radical letter concerning toleration, ${ }^{32}$ Voltaire was beginning to formulate the theory of separation between

${ }^{29}$ Fox, "Secularization," 306.

${ }^{30}$ See Immanuel Kant, Religion within the Bounds of Bare Reason (Indianapolis, IN: Hackett, 2009).

${ }^{31}$ See Voltaire, Treatise on Toleration (London: Penguin, 2016).

${ }^{32}$ See John Locke, Two Treatises of Government and a Letter Concerning Toleration (New Haven, CT: Yale University Press, 2003). 
church and state, considering a civil and ecclesiastical government to be an insult to reason. In defense of the philosophy of religion, which he called the "sister of religion," Voltaire wrote that reason is gentle and humane, and encourages tolerance, being more effective in persuading people to obey the law. Thus, he proclaimed reason as foundational to avoid the fanaticism and superstition that led to religious persecution. ${ }^{33}$

The intellectual Thomas Paine (1737-1809) was a deist from a Quaker family. In defense of reason, he argued that his mind was his own church, that reason was the most formidable weapon against every kind of error, and that human beings could discover God by the exercise of reason. He believed the Bible should be subject to the scrutiny of reason, because the Scriptures were not God`s Word, and the biblical revelation with its mysteries, miracles, and prophecies was just a fraud or a human invention. ${ }^{34}$

Paine classified the biblical histories of the creation, fall, flood, incarnation, and expiation through Christ, as well as the biblical concept of the triune God, as fables and myths. He wrote that the biblical revelation was irreconcilable with the divine gift of reason and the knowledge of the power and wisdom of God that humanity gained by the sciences ${ }^{35}$ and by studying the structure of the universe. Paine defended that the true Word of God was nature - "the Bible of the creation," an "exhaustive text" through which it was possible to know God by the union

${ }^{33}$ Voltaire, Treatise on Toleration, 6-15, 24-35, 108-14, 137.

${ }^{34}$ See Thomas Paine, Age of Reason (Grand Rapids, MI: Michigan Legal, 2014), 44-49, 138-42.

${ }^{35}$ It is important to note that, although scientific and technological advancement is one of the Nones' causative factors, as it strengthens secularism and pluralism, as this research will demonstrate, science itself is not incompatible with faith and has many positive characteristics for Christian faith and mission. The printed literature, the mass communication, the pieces of equipment that facilitates the preaching and the services of collective worship, and the means of transport are some of the many benefits of science for the exercise of the Christian faith and mission. 
between science and the machinery of the universe. He saw God as the Almighty, "the great mechanic of the creation; the first philosopher and original teacher of all science." ${ }^{\circledR 36}$

Finally, Paine decried all systems of religion and religious institutions as human inventions, created with the objective of terrifying and enslaving human beings, and to monopolize power and profit. He also criticized the union between church and state, calling it an adulterous connection. Paine proclaimed a revolution in the system of religion through reason, according to which every preacher ought to be a philosopher, and every house of devotion a school of science. ${ }^{37}$

In short, under the influence of the Enlightenment movement, philosophers wrote that cognitive progress would be achieved through abandoning faith, instinctual impulses, and irrational thoughts; and that by the use of reason, without divine revelation, it was possible to discover fundamental truths about the nature of reality. For them, through science and the use of reason, people could understand the laws that govern nature and focus on the objective facts of life, becoming able to control not only natural factors but also their destiny. ${ }^{38}$

In the nineteenth century and early twentieth century, intellectuals created different theories based in the Enlightenment movement, all of them without religious foundation. From Auguste Comte (1798-1857) came the positivist theory, defending a positive philosophy with new social doctrine based on the sciences. ${ }^{39}$ Charles Darwin (1809-1882) produced the theory of

${ }^{36}$ Paine, Age of Reason, 89-93, 122-24.

${ }^{37}$ Paine, Age of Reason, 42-43, 281-82.

${ }^{38}$ See Fox, "Secularization," 308.

${ }^{39}$ See Augusto Comte, Discurso preliminar sobre o Espirito Positivo (São Paulo, SP: Ridendo Castigate Mores, 2002). 
evolution by natural selection. ${ }^{40}$ Herbert Spencer (1820-1903) proposed the principle of evolutionary progress for the physical world, biological organisms, the human mind, and human culture and societies. ${ }^{41}$ Karl Marx (1818-1883) established the communist ideology, also known as Marxism, in which he predicted the abolition of capitalism in favor of a system with common ownership of the means of production, that through a dynamic of emancipation would result in an egalitarian society without religion. ${ }^{42}$ Friedrich Nietzsche (1844-1900) proposed God's death, ${ }^{43}$ and the psychoanalytic theory of Sigmund Freud (1856-1939) treated religion as an illusion. ${ }^{44}$

\section{Sociology of Religion}

In this environment of progressive disregard of religion propagated by the Enlightenment movement, the sociology of religion was born, proposing to interpret the phenomenon of secularization, considering religion as a social fact. In general, sociologists of religion have seen the process of secularization as inevitable and taking different forms in diverse societies according to their institutional or religious characteristics. However, there has been disagreement as to the outcome of this process. A few sociologists have argued that over time, religion would disappear, resulting in a society without religion. Most theorized that religion would not

${ }^{40}$ See Charles Darwin, The Origin of Species: By Means of Natural Selection (New York: Cambridge University Press, 2009).

${ }^{41}$ See Herbert Spencer, The Study of Sociology (London: Henry S. King, 1873).

${ }^{42}$ See Karl Marx, Capital: A Critique of Political Economy, Das Kapital 1 (London: Penguin, 2004); Karl Marx and Frederick Engels, Manifesto of the Communist Party (Peking: Foreign Languages Press, 1970).

${ }^{43}$ See Friedrich Nietzsche, Beyond Good and Evil (New York: Vintage Books, 1966); Peter Fritzsche, ed., Nietzsche and the Death of God (Long Grove, IL: Waveland Press, 2007).

${ }^{44}$ See Sigmund Freud, The Future of an Illusion (New York: W. W. Norton, 1961); Sigmund Freud, Moses and Monotheism (Great Britain: The Hogarth Press and The Institute of Psycho-Analysis, 1939). 
disappear, but would change its form of expression and win a legitimate space in the private sphere. Also, many predicted that there would be a process of internal secularization in institutions, which, although maintaining their religious symbolism, would seek to adapt to modern requirements. However, the dramatic resurgence of religion over the last three decades was a surprise for those that work with the sociology of religion. Nobody had predicted such a phenomenon. ${ }^{45}$ As Cox and Ikeda explains, it has come as a surprise to many scholars, that the social changes caused by technological and scientific advances, as well as urbanization and economical marketing, instead of marginalizing or even making religion disappear, as expected, testified a revival of spirituality, or an inexplicable kind of renaissance of religion. ${ }^{46}$

This work will analyze selected elements that characterize the theories of secularization, taking as base the writings of Max Weber (1864-1920) and Emile Durkheim (1858-1917), the parents of this branch of sociology, ${ }^{47}$ who lived in the same period when the main theories of the virtual death of God, described above, were established. The study also will consider the work of some followers of Weber, including Bryan Wilson (1926-2004), Thomas Luckmann (19272016), and Roy Wallis (1945-1990); some followers of Durkheim, including Rodney Stark (1934- ), William Bainbridge (1940- ), Grace Davie (1946- ), and Laurence Iannaccone (1954); and three independent scholars: Peter Berger (1929-2017), Charles Taylor (1931- ),

\footnotetext{
${ }^{45}$ See Martin Riesebrodt and Mary Ellen Konieczny, "Sociology of Religion," in The Routledge Companion to the Study of Religion, ed. John Hinnels (New York: Routledge, 2010), 145.

${ }^{46}$ Harvey Cox and Daisaku Ikeda, The Persistence of Religion: Comparative Perspectives on Modern Spirituality (London - New York: I. B. Taurus, 2009), 34.

${ }^{47}$ Fox, "Secularization," 307.
} 
and Talal Asad (1932- ). It is not the purpose of this study to critically analyze the selected elements of secularization theories, but only to review them as a base for the study of the Nones in the United States and Brazil.

\section{Elements of Secularization Theories of Weber and Followers}

\section{Max Weber (1864-1920)}

The German intellectual Max Weber understood religious disenchantment and the transfer of religion from the public sphere to the private as two main characteristics of secularization. He was critical of the Enlightenment and argued that there were some spheres of existence in which science did not operate, but understood that modernization and specialization of labor, urbanization, and industrialization would have a profound impact on religion. He theorized that Protestantism brought in itself the seeds of secularism. First, it disseminated an objective and impersonal version of brotherly love that manifested through the rational organization of the social environment, bringing as a consequence the rationalization and weakening of religious incantation. Secondly, Weber pointed out that by encouraging scientists to use natural laws as a means of knowing God, Protestantism allowed scientific explanations to undermine religious ones, which would weaken religiosity. ${ }^{48}$

In his research on the social and economic impact of religion, Weber made a broad study of religions in China and India, besides Western Christianity and Judaism. He concluded that religion was not exclusive of reason because the Western and Eastern religions developed in

\footnotetext{
${ }^{48}$ Max Weber, The Protestant Ethic and the Spirit of Capitalism (New York: Routledge, 2001), 105-12.
} 
different ways, and pointed out that Protestantism led to the birth of capitalism, bureaucracy, and the rational and legal estate of the Western countries. ${ }^{49}$

Protestant asceticism in Weber`s view is a reference to the ethic defended especially by Calvinism, Methodism, Pietism, and the Baptists that characterized the relationship of their members with the external world. According to him, those movements developed the concept of "calling," or the idea that the highest moral obligation of believers is to fulfill their duty in worldly affairs. In this point of view, there is a close connection between religion and day-to-day activities, in contrast to Catholic monasticism, in which the objective was to transcend mundane existence. In the monastic concept, the virtuous religious were those who "fled the world," while in Protestant asceticism the moral-ethical obligation of believers took them "into the world," showing the primacy of ethics over the world through the influence of religion on practical behavior. ${ }^{50}$ In this perspective, the well-marked calling was an exercise of ascetic virtue, a proof of the state of grace, while unwillingness to work was symptomatic of a lack of grace. Labor and industry were believers' duty to God. ${ }^{51}$

According to Weber, the Calvinist doctrine of predestination is a clear example of the Protestant ethic affecting the relationship between religion and world affairs. In Calvinism, God, in his sovereignty and immutable purpose, predestined some humans and angels for everlasting life and others for everlasting death. Moreover, since God`s decrees are unchanging, those chosen would never lose grace, and the rejected ones would never have it. In other words, once

\footnotetext{
${ }^{49}$ See Weber, The Protestant Ethic; Max Weber, The Religion of China: Confucianism and Taoism (Glencoe, IL: The Free Press, 1951); Max Weber, The Religion of India: The Sociology of Hinduism and Buddhism (Glencoe, IL: The Free Press, 1958).

${ }^{50}$ Weber, The Protestant Ethic, 53-55, 71-75.

${ }^{51}$ Weber, The Protestant Ethic, 105, 122.
} 
saved, always saved, and once lost, always lost. It was the duty of believers to consider

themselves chosen and saved, and to combat all doubts as devil's temptations, keeping the trust in Christ that was the result of a deeper faith. At the same time, they should give evidence of salvation through good works, which were not a means of attaining grace, but only the subjective external signs of faith. Unlike the Catholic system with its cycle of sin, repentance, atonement, and release followed by renewed sin, and the balance of merit that could be adjusted by temporal punishments or by the church's means of grace, Calvin proposed a new perspective. According to Calvin, God does not demand singular good works of believers, but a life of good works introduced into a unified system, continuous progress which can only be achieved by the supernatural influence of God's grace..$^{52}$

According to Weber, the essence of the spirit of modern capitalism is the idea that economic acquisition is no longer only a means for the satisfaction of material needs; human life is dominated by making money, with acquisition as the ultimate goal of life. He also stated that psychological sanction for wealth, labor as the only means of attaining certainty of grace, and seeing business activity as a calling are essential principles of modern capitalism. ${ }^{53}$ In this sense, it became viable to become wealthy without a life of idle luxury or self-indulgence. ${ }^{54}$ For Weber,

\footnotetext{
${ }^{52}$ Weber, The Protestant Ethic, 65-66, 71, 150.
}

${ }^{53}$ Weber, The Protestant Ethic, 107, 121.

${ }^{54}$ Wesley recognized that, although Protestantism encouraged the labor that produced wealth, over time wealth could affect spirituality. He said: "I fear, wherever riches have increased, the essence of religion has decreased in the same proportion. Therefore, I do not see how it is possible, in the nature of things, for any revival of true religion to continue long. For religion must necessarily produce both industry and frugality, and these cannot but produce riches. But as riches increase, so will pride, anger, and love of the world in all its branches. How then is it possible that Methodism, that is, a religion of the heart, though it flourishes now as a green bay tree, should continue in this state? For the Methodists in every place grow diligent and frugal; consequently, they increase in goods. Hence, they proportionately increase in pride, in anger, in the desire of the flesh, the desire of the eyes, and the pride of life. So, although the form of religion remains, the spirit is swiftly vanishing away. Is there no way to prevent this - this continual decay of pure religion? We ought not to prevent people from being diligent and frugal; we must exhort all Christians to gain all they can, and to save all they can; that is, in effect, to grow rich." Robert 
the impetus for the accumulation of wealth without worldly pleasures is Protestant asceticism, which in addition to elevating moral values also promotes entrepreneurship through rational capitalism. Rational capitalism, Weber explained, implies two things: a disciplined workforce and the regularity of capital investment. ${ }^{55}$

Weber also stated that, to the extent that the Protestant ethic contributed to modern capitalism, it contributed to the secularization process. Labor as a calling provided an ethical justification of the modern specialized division of labor and the development of skill, with a quantitative and qualitative improvement in production. ${ }^{56}$

In short, Weber theorized that Protestant ethics, especially from the Calvinist, Methodist, Pietist, and Baptist branches, contributed to the establishment of modern capitalism in several ways. First, by advocating a biblical theology that encouraged members' involvement with the affairs of the world to spread the kingdom of God through a Christian ethic that testified positively in favor of the Gospel. Second, by considering hard work, along with a spirit of frugality or economy, as a calling from God. In this case, industry, specialization, economy, and production came to be regarded as manifestations of God's grace. Since salvation and election were the work of God`s grace, professional and economic performance were outward manifestations of this grace and the genuine faith, as evidence of election. This process was what Weber called the spirit of capitalism. Weber also noted that Protestant leaders came to predict that while Protestant ethics curbed the excessive and worldly use of money, over time, the growth in wealth promoted by this concept of labor as a calling would necessarily produce pride,

Southey, The Life of Wesley: and the Rise and Progress of Methodism, vols. 1-2 (New York: J. Seymour Print, 1820), 379-80.

\footnotetext{
55 Weber, The Protestant Ethic, 55, 104-5.

56 Weber, The Protestant Ethic, 107-9.
} 
love of the world, and decay of the true religion. Institutions would base their evaluative criteria on the principles of democracy, meritocracy, and economic virtue, leaving religiosity as only an underlying principle, which would lead to the slow process of religious roots dying. Thus, Weber proposed that Protestant asceticism contributed not only to the development of capitalism, but also to the establishment of democracy, specialization, bureaucracy, and rational social organization, sowing the seeds of secularism.

One of the most critical elements of Weber`s analysis of secularization was what he called "disenchantment of the world," an expression borrowed from author Friedrich Schiller, ${ }^{57}$ to describe a kind of weakening of the magical elements of human thought through the Enlightenment, in which scientific understanding was more highly valued than belief and processes were oriented toward rational goals. For Weber, the Enlightenment ideals of moral enrichment, cumulative technological advancement through rationalization, and scientific improvement resulted in the disenchantment of the world. ${ }^{58}$

Weber seems to have had two ideas about disenchantment. First, a secular aspect, in that as ideas became systematic and consistent, and scientific and technological advances were made, the worldview guided by mystical or magical elements would change to a mechanistic view of the world guided by causal elements. In this case, the world is seen as a God-ordained cosmos and therefore, somehow meaningful and ethically oriented. All things are taken to be explainable in rational and scientific terms, and religious and magic understanding is seen as ignorant and backward. According to Weber, this process of disenchantment and secularization promoted by

\footnotetext{
${ }^{57}$ Richard Jenkins, "Disenchantment, Enchantment and Re-Enchantment: Max Weber at the Millennium," Max Weber Studies 1 (2000): 11-32, http://www.jstor.org/stable/24579711.

${ }^{58}$ See Riesebrodt and Konieczny, “Sociology of Religion,” 149.
} 
the rationalistic principle would eventually eliminate the religious ethic and the religious control of economics, political, and cultural institutions. ${ }^{59}$

The second aspect of disenchantment is the rupture of the moral, cognitive, and interpretative unity that characterized the worldview of the enchanted pre-modern world, shifting the transcendental and spiritual values from the public sphere to the particular sphere. Weber recognized that in this new perspective, those who would choose to lead a life based on religious principles would go against the institutional bureaucratic logic that no longer valued religious morality, but efficiency, performance, and utility. He theorized that it would be possible to maintain a religious ethos only in small voluntary associations at the social margins, and although a charismatic upheaval could change the inner attitudes of people, it would be unlikely to succeed in the modern West, because of the rigidity and efficiency of bureaucratic systems. ${ }^{60}$

Thus, Weber saw the process of secularization as inevitable, given the social forces in progress, resulting in religious disenchantment and the transfer of religion from the public sphere to the private sphere. In his conception, religion would not disappear, but would be weakened as part of this process.

\section{Bryan R. Wilson (1926-2004)}

Weberian in orientation, and considered the foremost British sociologist of religion of his day, ${ }^{61}$ Wilson emphasized two elements related to secularization theory: the weakening of religious institutions and the multiplication of sectarian movements. According to him, the

\footnotetext{
${ }^{59}$ See Max Weber, Essays in Sociology (New York: Oxford University Press, 1958); Riesebrodt and Konieczny, "Sociology of Religion," 148-49.

${ }^{60}$ Weber, Essays in Sociology.

${ }^{61}$ Fox, "Secularization," 309.
} 
process of secularization resulted in the weakening of religious institutions, which lost their power to shape society. ${ }^{62}$ He disagreed with those who saw change instead of a decline in religion in Western society. For him, what was occurring at his time was a replacement of religious ideas by secular ideas. ${ }^{63}$ Modern society was leading people to be highly individuated, and consequently there was no community of feeling to which the churches could minister, he explained. ${ }^{64}$

In describing the social context of secularization, Wilson found that religion was losing its monopoly as a supportive agency to human beings for the fulfillment of their desires.

According to him, new and alternative channels for the expression of human emotions took the place that was once exclusive to religion. The system of religious community was replaced by the system of secular society. ${ }^{65}$ In this shifted system controlled not by moral principles but by impersonal and amoral techniques and routines, ${ }^{66}$ actions would be "calculated, systemic, regulated, and routinized. ${ }^{\prime 67}$

In a secular society, people no longer depend on supernatural concepts and moral presuppositions, but technical imperatives. It is supposed that people can solve personal and

${ }^{62}$ Wilson, Religion in Secular Society, 14.

${ }^{63}$ Wilson, Religion in Secular Society, 7.

${ }^{64}$ Wilson, Religion in Secular Society, 42.

${ }^{65}$ Wilson pointed out: “The concept of community be set over against the concept of society... If we regard the community as the ongoing local group, and society as the autonomous, internally structured system of segmented relationships of large numbers of people, we can make the further point: the community is essentially religious; the society is essentially secular." Bryan Wilson, "Aspects of Secularization in the West," Japanese Journal of Religious Studies 3, no. 4 (December 1976): 261-62.

${ }^{66}$ Bryan Wilson, Contemporary Transformation of Religion (Oxford: Oxford University Press, 1976), 20.

${ }^{67}$ Bryan Wilson, "Secularization: The Inherited Model," in The Sacred in a Secular Age: Toward Revision in the Scientific Study of Religion, ed. Phillip E. Hammond (Los Angeles, CA: University of California Press, 1985), 19. 
social problems with science and rational planning, without supernatural help. ${ }^{68}$ Thus, "churches are losing direct influence over the ideas and activities of men." ${ }^{99}$ As an example, Wilson cited social policies based on democratic principles. In this case, instead of seeking supernatural intervention in their everyday affairs, people began to use instrumental action and decisionmaking by majority vote. ${ }^{70}$

According to Wilson, this new way of managing life directly affected matters crucial to human beings such as distributions of power, wealth, prestige, choices, and the general pattern of life circumstances. ${ }^{71} \mathrm{He}$ also explained that the idea that humans had to accept their luck, or expect God to enter the human environment to guide their destinies, was losing strength, giving way to sensible policies based on concrete actions. ${ }^{72}$ It was "the elimination of mystical, sacerdotal elements from the religious system." ${ }^{\prime 3}$ In the process of secularization, the church lost the authority and capacity to define what people should believe, accept, and practice regarding moral principles.

Wilson also emphasized the role of technology in the secularization of religious institutions, especially in Western countries. First, technology gave life to the entertainment industry, which not only competed for people`s time, attention, and money, but also offered a set of alternative norms and values. Technology also undermined the near-monopoly of churchowned communication. The church, which once represented a powerful voice in the local

\footnotetext{
${ }^{68}$ Wilson, “Aspects of Secularization,” 266-67.

${ }^{69}$ Wilson, Religion in Secular Society, 22.

${ }^{70}$ Wilson, Religion in Secular Society, 45.

${ }^{71}$ Wilson, Religion in Secular Society, 45.

72 Wilson, Religion in Secular Society, 45.

${ }^{73}$ Wilson, “Aspects of Secularization,” 261.
} 
community, became just another voice among many divergent religious messages, and later competed with increasingly efficient voices that through mass communication technologies began to offer non-religious distractions to the people. ${ }^{74}$

According to Wilson, another factor that weakened the influence of churches as a determining voice in Western societies was the advancement of science. With the application of science in many areas of knowledge and its positive and tangible results came respect and approval for experimental study. As a result, religious voices came to be seen as representing only the early stages of social development. ${ }^{75}$ Therefore, according to Wilson, human individualization, new agencies and new channels of human orientation, and the advent of technology and experimental science in the context of secularization were factors that promoted the societal process and contributed to the weakening of religious institutions and their power to shape society.

The second main element emphasized by Wilson related to secularization was the emergence of many sects ${ }^{76}$ as a religious response to secularism. According to him, the sects would first emerge as a reaction to the dominant religious tradition coming to terms with the secular order of things. However, he disagreed with the prevailing opinion in his day that sects

\footnotetext{
${ }^{74}$ Wilson, Religion in Secular Society, 49.

${ }^{75}$ Wilson, Religion in Secular Society, 51, 54.
}

${ }^{76}$ According to Wilson's conception, a sect has the following characteristics: "it is a voluntary association; membership is by proof to sect authorities of some claim to personal merit—such as knowledge of doctrine, affirmation a conversion experience, or recommendation of members in good standing; exclusiveness is emphasized, and expulsion exercised against those who contravene doctrinal, moral, or organizational precepts; its selfconception is of an elect, a gathered remnant, possessing special enlightenment; personal perfection is the expected standard of aspiration, in whatever terms this is judged; it accepts, at least as an ideal, the priest all believers; there is a high level of lay participation; there is opportunity for the member spontaneously to express his commitment; the sect is hostile or indifferent to the secular society and to the state." Bryan Wilson, "An Analysis of Sect Development," American Sociological Review 24, no. 1 (February 1959): 4. 
would last only one generation and that when a sect became a denomination, ${ }^{77}$ its members would lose their initial enthusiasm and conform to the world their parents rejected. According to Wilson, sectarianism could remain even in the denominational phase, and secularism might inadvertently encourage this. ${ }^{78}$ He pointed out that sects first appeared as a critical response to compromises made by the dominant church, and might persist as critical responses to the secular world itself. ${ }^{79}$ On the other hand, Wilson pointed out that the multiplication of new denominations would lead to the process of ecumenism. For him, ecumenism was a sign of the weakness of organizations, because to the extent that they amalgamate, religious commitments are acculturated. ${ }^{80}$

Wilson argued that, although the secularization of the social system did not immediately displace the attributes of religiosity, nor make the concept of the supernatural disappear in the private and public spheres, religion would no longer be a determinant for social action. The system would become so inefficient and superficial that neither institutions nor people would operate primarily based on spiritual values. Observance of religion would persist, but there

\footnotetext{
${ }^{77}$ In contrast to a sect, a denomination, according to Wilson, has the following features: "it is formally a voluntary association; it accepts adherents without imposition of traditional prerequisites of entry, and employs purely formalized procedures of admission; breadth and tolerance are emphasized; since membership is laxly enrolled, expulsion is not a common device for dealing with the apathetic and the wayward; its self-conception is unclear and its doctrinal position unstressed; it is content to be one movement among others, all of which are thought to be acceptable in the sight of God; it accepts the standards and values of the prevailing culture and conventional morality; there is a trained professional ministry; lay participation occurs but is typically restricted to particular sections of the laity and to particular areas of activity; services are formalized and spontaneity is absent; education of the young is of greater concern than the evangelism of the outsider; additional activities are largely non-religious in character; individual commitment is not very intense; the denomination accepts the values of the secular society and the state; members are drawn from any section of the community, but within one church, or any one region, membership will tend to limit itself to those who are socially compatible." Wilson, "Analysis of Sect Development," 4-5.

${ }^{78}$ Bryan Wilson, The Social Dimensions of Sectarianism (Oxford: Oxford University Press, 1990).

${ }^{79}$ Bryan Wilson, “The Persistence of Sects," Diskus 2 (1993): 1-2.

${ }^{80}$ Wilson, Religion in Secular Society, 122.
} 
would be fundamental changes in ideological and procedural terms toward secularization, such that religion would become more a cultural and customary expression than a spiritual force capable of changing values. However, Wilson concluded that the inheritance of the secular model did not predict an eventual total eclipse of religion. He thought that religion would continue in the private sphere and even acquire new forms of expression, some dissociated from the culture in which they would appear. ${ }^{81}$

Thus, regarding the secularization process, Wilson theorized that although religion would persist and acquire new forms, religious institutions would face weakness in the societal context, and would lose their power to shape society. He also predicted the multiplication of new sects as a religious response to secularization.

\section{Thomas Luckmann (1927-2016)}

The Slovenian sociologist Luckmann agreed with the Weberian position about the transference of religion from the public to the private sphere as an effect of secularization. He also agreed with Wilson's position on the weakening of religious institutions in the same context. Based on those positions, he proposed that the main characteristic of secularization was the individualization of religion. ${ }^{82} \mathrm{He}$ pointed out that sociology of religion, at the time when he wrote, was exclusively concerned with church-oriented religiosity. It considered church and religion to be essentially identical, ${ }^{83}$ and proposed that religion became marginal in modern society because of urbanization and industrialization. ${ }^{84}$ For him, general sociology viewed

\footnotetext{
${ }^{81}$ Wilson, "Secularization: The Inherited Model," 19-20.

${ }^{82}$ Thomas Luckmann, The Invisible Religion: The Problem of Religion in Modern Society (New York: Macmillan, 1967).

${ }^{83}$ Luckmann, The Invisible Religion, 26.

${ }^{84}$ Luckmann, The Invisible Religion, 38.
} 
industrialization and urbanization as socio-historical processes that led to religious disinterest and affected people in both urban and rural areas. Three factors in this decrease were the increasing economic gap between city and country, the growing rationalization of farming, and the diffusion of urban culture to the country through mass media. ${ }^{85}$

This marginal phenomenon of religion became clearer in Europe where the middle-class population, more affected by modernity, lost religious interest, leaving religion to the most culturally simple population, which was peripheral to the structure of modern society ${ }^{86}$ According to Luckmann, in the United States, churches had broad middle-class involvement, but this did not represent a reversal of the trend toward secularization. It represented how Americans saw the cultural, social, and psychological functions churches performed in the shaping of the American Dream ${ }^{87}$ In this sense, the secular ideas of the American Dream pervaded church religion through the adoption of the secular Protestant ethos. ${ }^{88}$

Luckmann theorized that there are two types of religious sources depending on the society. In societies where there is a complete institutional specialization of religion, it is taken for granted that the church mediates religion. In this case, individual religiosity appears in the form of church-oriented religiosity. However, in societies where religion is identical with the social form in which it appears, religiosity is reinforced by institutions that do not specialize in religious matters. In this case, norms endowed with sacred significance like charity, ethics, and patriotism are reinforced in a different institutional context. In both cases, the sacred cosmos is

\footnotetext{
${ }^{85}$ Luckmann, The Invisible Religion, 29-30.

${ }^{86}$ Luckmann, The Invisible Religion, 36.

${ }^{87}$ Luckmann, The Invisible Religion.

${ }^{88}$ As discussed in the section on Weber, rational capitalism, which includes labor, industry, meritocracy, specialization, liberty, and the idea that wealth is a sign of the grace of God, is a Protestant inheritance. Weber, The Protestant Ethic, 53-55, 71-75, 107, 121.
} 
extracted from the social context and internalized in the distinct layer of consciousness of the individual, forming religiosity. ${ }^{89}$

Luckmann saw institutional religion as harmful to the need for an everyday sacred cosmos. ${ }^{90}$ He defended the existence of uninstitutionalized religion, which he called the transcendent process, and proposed to explain how religiosity is established in the private sphere, giving rise to the invisible religion. ${ }^{91}$ According to him, because of the anthropological roots of religion, human beings typically transcend their biological nature by internalizing historicalsocial values. For Luckmann, this process of socialization by which one receives a meaningsystem or a moral universe of meaning is fundamentally a religious fact, through which human beings form their transcendent worldview and give meaning to their individual existence. ${ }^{92}$

Luckmann stated that worldview, as a historical, social reality within which human beings form identities, transcends biological nature, and carries out an essentially religious function with pragmatic and moral dimensions, fruits of the subjective matrix of the human conscience. ${ }^{93}$ Furthermore, worldview is universal in human society, without a specific social form of religion, and does not have an institutional basis, but a dialectical relationship to the social structure as a whole. It also leads people to administrate daily life in submission to the transcendent everyday life. ${ }^{94}$ Luckmann explained that the configuration of religion, represented by the worldview of the person, would form the sacred universe or the sacred cosmos of the

\footnotetext{
${ }^{89}$ Luckmann, The Invisible Religion, 72.

${ }^{90}$ Luckmann, The Invisible Religion, 85-86.

${ }^{91}$ Luckmann, The Invisible Religion, 50-51.

${ }^{92}$ Luckmann, The Invisible Religion, 52.

${ }^{93}$ Luckmann, The Invisible Religion, 53, 69.

${ }^{94}$ Luckmann, The Invisible Religion, 56, 58.
} 
individual, and permeate the various institutional areas of life, such as kinship, work, and social life. In this process, individuals form their consciences with models of conduct and interpretive schemes, as well as a hierarchic pattern of priorities, that determine what actions are more urgent than others. ${ }^{95}$ However, Luckmann stated that a sacred cosmos does not require a distinct and specialized institutional basis, and that it is transmitted from generation to generation through a general process, not a specialized institutional process. ${ }^{96}$

Therefore, Luckmann held that a society could have a worldview with a more or less sacred cosmos, without necessarily having a specialized institutional base that sustained that cosmos. For him, the more specialized religion grows, the more the role and participation of the laity in the sacred cosmos shrinks, leading to the formation of a body of experts and finally to some kind of ecclesiastic organization, as well as the transference of social controls over religious behavior from social religious representations to specific institutions. ${ }^{97}$

Furthermore, he pointed out that when church mediates religion through an official model, the institution and its traditions shape individual religion, transforming the sacred cosmos into a set of doctrines interpreted by an official body of experts. In general, those experts are mainly involved with issues of the sacred cosmos, and only theoretically with the everyday life of the people. As a result, individuals' relationship with the sacred cosmos and with matters of ultimate significance is not determined by them, but by an institution. There is a divorce from the typical routines and crises of the laity. ${ }^{98}$ Luckmann calls this a process of segregation of the

\footnotetext{
${ }^{95}$ Luckmann, The Invisible Religion, 70.

${ }^{96}$ Luckmann, The Invisible Religion, 61-62.

${ }^{97}$ Luckmann, The Invisible Religion, 66.

${ }^{98}$ Luckmann, The Invisible Religion, 72-73, 76.
} 
sacred cosmos from the world, making religion a routine fulfillment of particular requirements, divorced of real value. ${ }^{99}$

Based on this perspective, Luckmann identified a new religious scenario in modern industrial society: the rise of a social form of religion based on a disembodied sacred cosmos, and no longer on specialized institutions. ${ }^{100}$ According to him, separation between church and state, the state becoming a secular institution, and the church becoming an institution symbolized by power and wealth that is less relevant to real daily life, led to religion becoming a private matter. ${ }^{101}$ In addition, personal identity became essentially a private phenomenon, which is perhaps the most revolutionary attribute of modern society. ${ }^{102}$

Luckmann explained that the liberation of individual consciousness from the social structure, as well as freedom in the private sphere, built the sense of autonomy that characterizes the typical person in modern society. ${ }^{103}$ This autonomy is closely linked to the idea of consumer orientation. ${ }^{104}$ It means that individuals are left to their own devices to construct personal identity, choosing from the entire culture, including issues related to ultimate meanings. ${ }^{105}$ In this process of consumer orientation, the autonomous individual relates to the sacred cosmos as a buyer. Once religion is seen as a private affair, it is the person who defines how to relate to the sacred, selecting certain religious themes, guided only by personal consumer preferences. A

\footnotetext{
${ }^{99}$ Luckmann, The Invisible Religion, 75, 76.

${ }^{100}$ Luckmann, The Invisible Religion, 91-92, 103.

${ }^{101}$ Luckmann, The Invisible Religion, 94.

${ }^{102}$ Luckmann, The Invisible Religion, 97.

${ }^{103}$ Luckmann, The Invisible Religion, 97.

${ }^{104}$ Luckmann, The Invisible Religion, 98.

${ }^{105}$ Luckmann, The Invisible Religion, 98.
} 
variety of models are socially available, and no official model exists. Also, the religious formation of the individual is determined by a certain level of subjective reflection and choice, leading to a system of ultimate significance that is syncretic and vague, resting primarily on emotions and sentiments. ${ }^{106}$

In short, Luckmann did not see the modern sacred cosmos in the secularized context as based in the churches, the state, or the economic system, but in direct accessibility to the individual. In the exercise of autonomy and personal preferences, the individual chooses from an assortment of religious themes, making religion a phenomenon of the private sphere, and an invisible issue. ${ }^{107}$ Luckmann suggested three forms of support for the exercise of religiosity in this private context. First, individual religiosity can be supported by another person in the private sphere. Second, support can come from the nuclear family, which "remains the most important catalyst of private universes of significance." ${ }^{108}$ Finally, friends, neighbors, colleagues, and hobby-mates are suggested by Luckmann as essential for the support of the private universe of religion. ${ }^{109}$

Some years later, in his book in partnership with Peter Berger, The Social Construction of Reality, Luckmann seemed to have changed his thinking that church is an institution that hinders the most profound spiritual experience of the individual with the sacred. In this book, the authors wrote that the process of conversion, as well as spiritual growth and maturation, can only occur within a religious community. "It is only within the religious community, the ecclesia, that the

\footnotetext{
${ }^{106}$ Luckmann, The Invisible Religion, 100-103.

${ }^{107}$ Luckmann, The Invisible Religion, 103.

${ }^{108}$ Luckmann, The Invisible Religion, 106.

${ }^{109}$ Luckmann, The Invisible Religion, 106.
} 
conversion can be effectively maintained as plausible." 110 This new perspective became clearer yet in another book the same authors published almost thirty years later, in which they proposed that the remedy for modern pluralism, and the consequent instability and crises of meaning, is recovering the idea of community. ${ }^{111}$ For the purpose of this study, the individualization of religion will be considered as Luckmann`s characteristic of the modern process of secularization.

\section{Roy Wallis (1945-1990)}

According to Wallis, the first element that characterizes secularization is the rise of new religious movements. He described two positions on this issue. The first position is that new religions are primarily a manifestation of secularization. In this case, they do not change the course of the secularization phenomenon, because the religious expression is just a reflex of secularized society. ${ }^{112}$ The second position is that new religious movements are not a manifestation of, but a response to secularization; something intentionally established, and capable of reversing the secularization trend. ${ }^{113}$

For Wallis, the understanding of new religious movements as a manifestation of secularization was based on Durkheim's position that religion is a reflection of the prevailing social structure, being a source of collective identity and solidarity. ${ }^{114}$ It means that if there is a

110 Peter L. Berger and Thomas Luckmann, The Social Construction of Reality: A Treatise in the Sociology of Knowledge (London: Penguin Books, 1966), 177-78. The Invisible Religion, published in 1967, was first published in 1963 in German. See Thomas Luckmann, Das Problem der Religion in der modernen Gesellschaft: Institution, Person und Weltanschauung (Freiburg: Rombach, 1963).

${ }^{111}$ Peter Berger and Thomas Luckmann, Modernity, Pluralism and the Crisis of Meaning: The Orientation of Modern Man (Gütersloh: Bertelsmann Foundation, 1995).

57.

${ }^{112}$ Roy Wallis, The Elementary Forms of the New Religious Life (London: Routledge \& Kegan Paul, 1984),

${ }^{113}$ Wallis, Elementary Forms, 57.

${ }^{114}$ Wallis, Elementary Forms, 57. 
change in social structure, there must necessarily be a corresponding change in the predominant religious expression. ${ }^{115}$ In this case, if society has become more rational, individualistic, and centered on human existentialism in the context of modernity, the appropriate form of religion for this scenario must be associated with worship that celebrates the idealization of the individual, a kind of "cult of men." 116 Moreover, if this individualism of modern society is highly differentiated, it is natural to expect a multiplicity of religious forms, including those that encourage the complete realization of the self. ${ }^{117}$

Another factor that Wallis raised in the context of religious movements as a manifestation of secularization is the "spiritual and mystical" as well as "tolerant and syncretic" characteristics of many of these new movements. ${ }^{118} \mathrm{He}$ explained that this way of expressing religion is well adapted to a modern industrial society characterized by the democratic values of openness, free expression, and respect for the individual. ${ }^{119}$

Wallis stated that, on the other hand, the position that new religions are a response to secularization is founded on two arguments. First, that sectarian movements are stimulated by secularization; in this case, when a church tradition is relatively stable, but at the same time affected by secularization, revival occurs through the emergence of sectarian schisms within the tradition. It is an intentional action to reverse the secularization trend. ${ }^{120}$ The second argument for new religious movements as a response to secularization is the rise of new faiths or "cults"

\footnotetext{
${ }^{115}$ Wallis, Elementary Forms, 57.

116 Wallis, Elementary Forms, 58.

${ }^{117}$ Wallis, Elementary Forms, 58.

${ }^{118}$ Wallis, Elementary Forms, 58.

${ }^{119}$ Wallis, Elementary Forms, 58.

${ }^{120}$ Wallis, Elementary Forms, 60.
} 
outside of prevailing traditions. The idea is that "lower rates of church involvement tend to be associated with higher rates of cult formation and growth." ${ }^{121}$ Thus, if the secularization process produces a decline in traditional church involvement, in response, revivalism and religious innovations or "cults" increase, recruiting people to new faiths. ${ }^{122}$

Although Wallis did not openly defend either position, the general context of his arguments seems to suggest that to some extent he agreed with both positions, but maintained some reservations. To him, in some situations, new religious movements could be as much a manifestation of secularism as an answer to it. However, independent of whether the association between secularization and the new religious movements was reflexive or responsive, he disagreed with those who thought secularization was not a "self-limiting" phenomenon, and with those who thought that new religions were a negation of the secularistic theory. Wallis pointed out that the significant loss of church members and drop in church attendance in Britain in the nineteenth and twentieth centuries were not reversed enough by a revival movement in response. In other words, the modernization process weakened religion to a certain extent, and at the same time, it changed the form of religious manifestation. ${ }^{123}$

For him, new religious movements softened the effects of secularization, but would not reverse the decline in total church attendance rate or other effects:

Where traditional religion remains strong, as in Catholic southern Europe, or in Ireland, the new religions have little impact. But even where, as in the secularized world of Protestant western Europe and North America, a market exists, it is only a very small proportion of the population who are available for the more clearly religious of the new movements, and even then, often for only very brief periods during the transition to adulthood. ${ }^{124}$

\footnotetext{
${ }^{121}$ Wallis, Elementary Forms, 60.

${ }^{122}$ Wallis, Elementary Forms, 60.

${ }^{123}$ Wallis, Elementary Forms, 59-61.

124 Wallis, Elementary Forms, 72.
} 
While on the one hand Wallis did not have an optimistic view of the reversibility of secularism by new religious movements, on the other hand, he recognized their importance, either as a manifestation or as a response to the phenomenon.

A second element of the view of secularization that Wallis developed along with Bruce is the "diminution of the social significance of religion," through three features of modernization: social differentiation, societalization, and rationalization. ${ }^{125}$ Social differentiation is the process by which specific features or functions previously embodied in or carried out by religious institutions are transferred to secular specialist institutions. It includes particular institutions in such crucial social areas as education, health, welfare, and social control. In addition, modern economic growth brought about a pluralistic range of occupations and different life situations that imply specialization, training, and evaluation as part of a meritocracy instead of a moral order. $^{126}$

Regarding societalization, Wallis and Bruce explained that this is an element identified by Wilson, ${ }^{127}$ through which life becomes organized not locally, but societally. The small-scale community gives way to the large-scale industrial and commercial modern state, coordinated through massive, impersonal bureaucracies, and the development of anonymous urban agglomerations. In this context, the single moral and religious system declines, because without 59.

\footnotetext{
${ }^{125}$ Wallis and Bruce, "Secularization: The Orthodox Model," 11.

126 Wallis and Bruce, "Secularization: The Orthodox Model," 12.

${ }^{127}$ See Bryan Wilson, Religion in Sociological Perspective (Oxford: Oxford University Press, 1984), 154-
} 
basic communities, naturally, religion loses its strength, becoming privatized and pushed to the margins of the social order. ${ }^{128}$

Rationalization, according to Wallis and Bruce, is a change in the way people think and act under the influence of modernity, stimulated especially by two Judeo-Christian seeds: the transcendence of God and monotheism. Based on Weber and Berger, they pointed out that the transcendence of God allowed people to see the world as secular and permitted its rational and empirical exploration. On the other hand, monotheism encouraged ethical rationalization, or the reduction of theology and ethics to a rational system of ideas, with the elimination of the magical means of salvation. ${ }^{129}$

Therefore, the rise of new religious movements and the diminution of the social significance of religion are vital characteristics of secularization in Wallis's view.

\section{Summary of Weber and Followers}

According to Weber and some of his followers, elements that characterize secularization in the contemporary period include religious disenchantment and the transfer of religion from the public to the private sphere, making religion an individual issue. Also, religious institutions are weakened in the societal context, as is the social significance of religion, with the consequent loss of power to shape society. Finally, the rise of new religious movements can be a manifestation of or response to secularization, including the multiplication of new sects, as well as technological advancement, especially in the area of mass communication.

\footnotetext{
${ }^{128}$ Wallis and Bruce, "Secularization: The Orthodox Model," 13.

${ }^{129}$ Wallis and Bruce, "Secularization: The Orthodox Model," 14.
} 
Elements of Secularization Theories of

Durkheim and Followers

\section{Emile Durkheim (1858-1917)}

A main element that characterizes Durkheim`s thinking on secularization is "the eternal and mutable nature of religion." ${ }^{130}$ Regarding the permanent or eternal aspect of religion, Durkheim theorized that it could never be obsolete, nor could there be a society without religion, because humanity has a religious nature, and needs religion to face the world with courage and as a source of life. ${ }^{131} \mathrm{He}$ stated that the exact function of religion is to make people act and help them to live. ${ }^{132}$ Also, he said that as a spiritual discipline, every religion is a set of techniques that helps people face the world confidently. ${ }^{133}$

Secondly, religion is permanent in Durkheim`s view because of its social value. For him, society is the soul of religion, and religion has social causes. ${ }^{134}$ In this sense, he stated that religion would persist not because it is necessarily true, but because it has a social function to play, through its two eternal elements: cult and faith. ${ }^{135} \mathrm{He}$ argued that religion is the most primitive of all social phenomena, from which come collective ideas such as law, morality, art, science, and politics, in such a way that "in principle everything is religious." "136 Furthermore, he

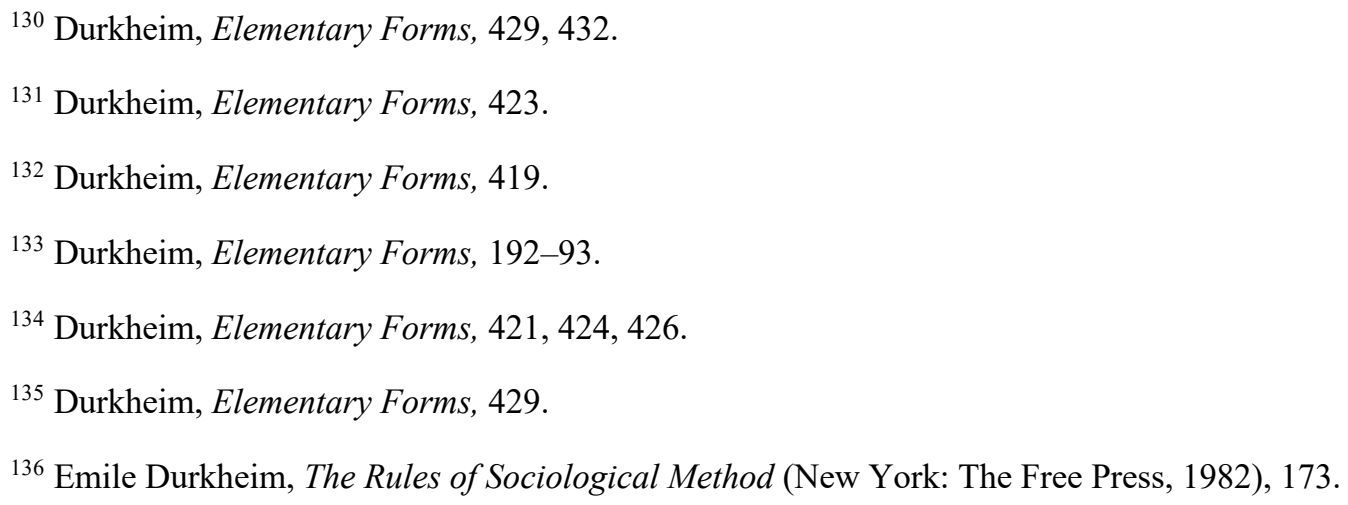

${ }^{130}$ Durkheim, Elementary Forms, 429, 432.

${ }^{131}$ Durkheim, Elementary Forms, 423.

132 Durkheim, Elementary Forms, 419.

${ }^{133}$ Durkheim, Elementary Forms, 192-93.

${ }^{134}$ Durkheim, Elementary Forms, 421, 424, 426.

${ }^{135}$ Durkheim, Elementary Forms, 429.

${ }^{136}$ Emile Durkheim, The Rules of Sociological Method (New York: The Free Press, 1982), 173. 
wrote that religion is the primitive way in which societies become aware of themselves and their history. ${ }^{137}$

Thus, according to Durkheim, religion is fundamentally social because society is established almost entirely through shared beliefs and practices. Acceptance of these beliefs unites people around moral obligations that dominate consciences, leading them to submit to a life of selflessness to fulfill religious requirements. ${ }^{138} \mathrm{He}$ pointed out that the social being is more abundant, complex, and permanent than the individual being, and the understanding of this fact leads the individual to feel attachment, respect, and submission to social and religious demands. $^{139}$

The third argument of Durkheim for the permanence of religion is the affirmation that science cannot be a substitute for religion or deny it. According to him, science cannot take religion`s place, because religion is action, and it makes people live, and while science expresses life, it cannot create life. Science also cannot, in principle, deny religion, because religion is a reality, and science cannot deny a reality. ${ }^{140}$

Regarding the mutable nature of religion, Durkheim predicted that under the influence of secularization, scientific advances, and rational religiosity, religion would take new forms of expression in society, not extinguishing itself, but changing according to new demands and new contexts. ${ }^{141}$ He wrote, "Religion seems destined to transform itself rather than disappear." ${ }^{142}$ In

\footnotetext{
${ }^{137}$ Emile Durkheim, Professional Ethics and Civic Morals (London: Routledge, 1992), 160.

${ }^{138}$ Emile Durkheim, The Division of Labor in Society (New York: The Free Press, 1984), 49, 130.

${ }^{139}$ Durkheim, Rules of Sociological Method, 144.

${ }^{140}$ Durkheim, Elementary Forms, 432.

${ }^{141}$ Durkheim, Elementary Forms, 432.

${ }^{142}$ Durkheim, Elementary Forms, 432.
} 
other words, according to Durkheim, a society cannot survive without systems of meaning and values, or without a global morality. Thus, as society changes, the forms of religion also change; the old structures are replaced by new ones, and therefore a cycle of decline and resurrection of religion occurs, but never its extinction. ${ }^{143}$

A practical benefit of religion for individuals and society in Durkheim`s perspective is its capacity to maintain social cohesion and to strengthen mutual feelings and ideas, ${ }^{144}$ which contributes to resilience and promotes a decrease in the indices of suicide. In his research about suicide, Durkheim discovered that "suicide varies inversely with the degree of integration of religious society." ${ }^{145} \mathrm{He}$ found also that some religions affected suicide more than others. In a comparation between Protestants, Catholics, and Jews, he pointed out that without exception, "Protestants show far more suicides than the followers of other confessions,"146 followed by Catholics; Judaism was the religion with fewest suicides. ${ }^{147}$

For him, the higher suicide numbers for Protestantism were a result of "its being a less strongly integrated church than the Catholic church." ${ }^{148}$ In short, Catholicism is an idealistic religion that imputes emphasis to thought and reflection, seeking to control the conscience, and demanding the blind submission of reason. Besides, Catholics accept their faith as ready-made, without scrutiny. This idealism forms a collective credo essential for a religious society, and produce an environment of social cohesion and general feeling that stimulates life and

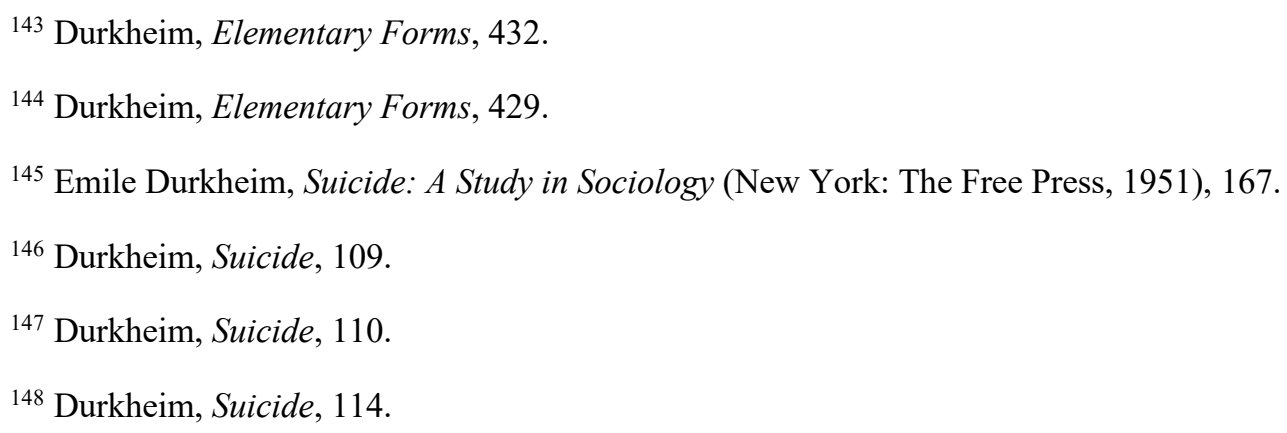


discourages suicide. ${ }^{149}$ On the other hand, Protestantism stimulates religious individualism, insofar as individuals are allowed to believe they are the authors of their faith, through personal biblical interpretation. This concession promotes individual judgment, resulting in less cohesion, vitality, and integration. The less integrated the religion and more individualistic the society, the greater the suicide rate. ${ }^{150}$ In the case of Jews, the same logic occurs. The high level of hostility to which they have been exposed over the centuries provokes an unusual solidarity among them. Each community becomes a compact and coherent society, with a strong sense of unity in defense of its traditions and values. In this cohesive religious society, suicide is minimized in comparison with other religious societies. ${ }^{151}$

In reasoning that the incidence of suicide is directly linked to the role society plays in individuals' lives, and also to highlight the influence religion can have on suicide rates, Durkheim discussed four main suicide types. The first is the "egoistic suicide," in which excessive individualism ${ }^{152}$ produces depression and melancholy, leading to suicide. Durkheim believed that the purpose of existence was to be a civilized human, or a social being who maintains relationships and service ties to others. As a social being, the individual necessarily

${ }^{149}$ Durkheim, Suicide, 112

${ }^{150}$ Durkheim, Suicide, 113 . Contradictory as it may seem, Durkheim found that the rate of suicide was much lower in the Catholic environment than in the Protestant one, but the homicide rate in Catholic countries (32 homicides per thousand) was much higher than in Protestant countries (less than 4 homicides per thousand). For him, the same reasons that influenced the decrease of one caused the increase of the other. Catholicism encourages non-rationality of faith and unquestioning acceptance, and produces a sense of community of faith, the public domain of conscience, and collective passion that encourages a decrease in suicide. Durkheim, Professional Ethics and Civic Morals, 118-20. However, Durkheim concluded that this combination of a public passion for conscience, lack of reflection, and lack of rationality to curb instincts and impulses resulted in increased homicides. "Whatever raises the temperature of passions in public life raises the level of homicide." Durkheim, Professional Ethics and Civic Morals, 119. Because Protestantism encourages rational faith and the individualization of beliefs, it has less collective passion. Moreover, focus on the individual increases the suicide rate, but at the same time, decreases the incidence of homicides. See Durkheim, Suicide, 110-14.

${ }^{151}$ Durkheim, Suicide, 114.

${ }^{152}$ Durkheim, Suicide, 168. 
depends on a society to express and serve, which is an objective basis of life. He pointed out that without this objective foundation, one will live artificially, illusively, without a goal for one's actions, and without any reason for existence. This kind of life is so selfish, or excessively individualist, that it will lead to suicide insofar as it loosens the bonds of the individual with society - the end upon which the self-best depends, and hence the bonds that bind the human being to life. ${ }^{153}$ Thus, "egoistic suicide results from man`s no longer finding a basis for existence in life."154

The second type of suicide Durkheim described was "altruistic suicide," which manifests exactly in opposition to the first. If excessive individualism breeds suicide, so does too much social integration. As an example, he showed that in primitive societies, there were three common types of suicides: "suicides of men on the threshold of old age or stricken with sickness," "suicides of women on their husbands` death," and "suicides of followers or servants on the death of their chiefs." 155 In all these cases, the people committed suicide because they believed it was their duty to do so. Failure to do so would lead to dishonor, punishment, and usually religious sanctions. In other words, the weight of society led individuals to take their own lives. In the altruistic suicide, social and collective values submerge individuation. ${ }^{156}$

The third type of suicide Durkheim classified was "anomic suicide," which resulted from a lack of regulation of human activities and the consequent suffering. For him, society exerts a controlling power over people, and its regulative action has direct influence on the suicide rate.

\footnotetext{
${ }^{153}$ Durkheim, Suicide, 172.

${ }^{154}$ Durkheim, Suicide, 219.

155 Durkheim, Suicide, 177.

${ }^{156}$ Durkheim, Suicide, 177-78.
} 
Anomic suicide occurs when society fails to control individual passions, leaving people in that society without a check-rein. ${ }^{157}$ Society becomes temporarily unable to exert this influence of control when it is disturbed by a painful crisis or when it undergoes sudden, albeit beneficial, change. ${ }^{158}$

Finally, the fourth type of suicide Durkheim described was "fatalistic suicide," which, unlike anomic suicide, is due to excessive regulation. It occurs when people have their futures blocked and their passions stifled by excessive discipline. Such suicides are typical in contexts where the rules are inescapable and inflexible. As examples, he cited the suicides of married women who had no children, slaves, and others subjected to physical or moral despotism. ${ }^{159}$

Durkheim saw a tendency to diminish the capacity of religion to prevent suicide, as the process of secularization was removing the conditions necessary for the positive influence of religion on the preservation of life. The first condition removed was the ability of religion to exercise substantial control over individuals in the practicalities of life. The vast system of dogmas and practices of Catholicism, with imperative precepts capable of penetrating every detail of earthly life, came to be questioned with the advent of more rational religion. Durkheim

${ }^{157}$ Durkheim, Suicide, 201-3.

${ }^{158}$ Durkheim, Suicide, 213. Durkheim illustrates two types of social crisis that result in increased suicide: First, when an economic disaster occurs in a society or country, forcing people to restrict their needs, standard of living, and level of consumption, this new reality requires greater self-control and the resumption of moral education with an emphasis on self-repression. The second example, in contrast, is the abrupt growth of power and wealth. If the conditions are changed, the standards governing the previous living conditions must be changed. In both cases, the changes are so sudden that society needs time to rebalance the scale and rearrange the value scale. Society cannot find the equilibrium point instantly to teach people the parameters of the new lifestyle. All regulation is momentarily absent until the boundaries between the just and the unjust, the possible and the impossible are met. However, this period of uncertainty leads to suffering and insecurity. The victims of the economic disaster suffer not only from the anguish of loss, but also from the lack of parameters that regulate their new reality. Those who are faced with abrupt power or riches have their appetites stimulated, become more demanding and less subject to controls, making the anomy or the state of lack of control even greater. The result is an increase in anomic suicide. Durkheim, Suicide, 214.

${ }^{159}$ Durkheim, Suicide, 239. 
explained that Catholicism gives no place for reflection, but encourages the faithful to passive acceptance by showing the church as God`s visible body and channel, without which there is no salvation. ${ }^{160}$ According to him, this form of religion, which prevents people from thinking freely, while maintaining profound mastery over consciousness, is what modifies the inclination to suicide. ${ }^{161}$ However, the Enlightenment movement's encouragement of the use of reason, and the Protestant emphasis on rational faith capable of scrutinizing Scripture and building an individual belief system, changed the picture. For Durkheim, this new form of religion "could not have the strong effect on their members necessary to set up an obstacle to suicide."162

The second condition removed from religion, according to Durkheim, was the view of God as an immanent being, capable of influencing and giving meaning to life. He pointed out that when God is seen only as a transcendent, timeless being, devoid of temporal activities and abandoning the world to us, "men cannot be prevented from taking their lives." ${ }^{163}$ For him, religion could prevent suicide not because it stimulated vague sentiment, but because of "the powerful and scrupulous discipline to which it subjected thought and conduct."164

Durkheim stated that Judaism had lower rates of suicide than Catholicism and Protestantism precisely by preserving the conditions set out above. In the case of Judaism, he pointed out that, in addition to its historic role in the fight against extinction, the maintenance of its most primitive religious forms in many respects is a strong ally against suicide. ${ }^{165}$ Durkheim

\footnotetext{
${ }^{160}$ Durkheim, Suicide, 342.

161 Durkheim, Suicide, 342.

${ }^{162}$ Durkheim, Suicide, 343.

${ }^{163}$ Durkheim, Suicide, 343.

${ }^{164}$ Durkheim, Suicide, 343.

${ }^{165}$ Durkheim, Suicide, 344.
} 
concluded that there was no proper view of prevention of suicide by religion because in the new secular society, religions would not have a strong enough effect on their members to avoid suicide. $^{166}$

In this scenario of changing forms of religion in the context of secularization, with the religion of reason and scientific advancement on the agenda, Durkheim envisioned two interesting perspectives. First, he predicted that there would be a strong emphasis on the individualization of faith, and that viable religious forms would be "those allowing more freedom to the right of criticism, to individual initiative." 167 Quoting Spencer, he wrote that the moment would come when each person could worship and practice their religion freely and according to their perspective. ${ }^{168}$ For him, as religion was born from the individual consciences of people, it must respond first to individual aspirations and only secondarily to collective aspirations. $^{169}$

Secondly, Durkheim envisioned that despite the strong emphasis on the individualization of religiosity, the idea of the church would remain. For him, the idea of religion was inseparable from the idea of church, because although the individual element of faith is evident, religion is collective. He understood that in this new perspective, the idea of church and collective worship would remain, but with less interference and control over the adherents, by relativizing the belief system.

${ }^{166}$ Durkheim, Suicide, 343.

${ }^{167}$ Durkheim, Elementary Forms, 158.

${ }^{168}$ Durkheim, Elementary Forms, 43. See also Herbert Spencer, "Ecclesiastical Institutions," in The Principles of Sociology (New York: D. Appleton, 1886), chap. 16.

${ }^{169}$ Durkheim, Elementary Forms, 175. 
Therefore, in short, the eternal and mutable nature of religion was the main element that characterized Durkheim`s thinking on secularization.

\section{Rodney Stark (1934- ) and William Bainbridge (1940- )}

Allied with Durkheim`s position that religion is intrinsically and socially necessary, and therefore, not subject to extinction, but to transformation through the process of secularization, ${ }^{170}$ Stark and Bainbridge worked together to establish a theory of religion according to which humans in their actions and behaviors seek "rewards" and avoid "costs." 171 According to the authors, applied to religion, this search for rewards precipitates the emergence of "sectary groups," as well as "cult movements," which together constitute a prominent element that characterizes secularization in their view. ${ }^{172}$

To better understand their reward theory, one must analyze the context of their ideas. Defending the permanent nature of religion, Stark asserted that secularization had failed to overcome belief in the supernatural or replace religion with science as the basis of moral judgment. ${ }^{173}$ Stark contradicted the most basic sense of the secularization theory that, insofar as “industrialization, urbanization, and rationalization increase, religiousness must decrease."174

For Stark, the secularization theory was correct to prophesy the separation of church and state, and the weakening of the influence of religion on other institutions, such as politics and

${ }^{170}$ Durkheim, Elementary Forms, 421, 424, 426, 429, 432. See also Rodney Stark and William Sims Bainbridge, A Theory of Religion (New York: Peter Lang, 1987), 279.

${ }^{171}$ Stark and Bainbridge, Future of Religion, 5, 285, 323-24.

172 Stark and Bainbridge, Theory of Religion, 132-42, 161-68.

${ }^{173}$ Rodney Stark, "Secularization, RIP," ASR Association for the Sociology of Religion: Oxford Academic no. 60 (1999): 250, 269, https://academic.oup.com/socrel/article/60/3/249/1658084.

174 Stark, "Secularization, RIP," 251. 
education. Another correct prophecy was the weakening of religious institutions themselves and their leaders. But in his view, the prediction that belief in the supernatural was bound to disappear worldwide was incorrect. ${ }^{175}$

He also disagreed with the assumption that secularization would be such an absorbing process that, once achieved, it would produce an irreversible mystical immunity applicable not only to Christianity but also to any supernatural belief. ${ }^{176}$ Similarly, Stark disagreed that the era of "scientific atheism" had come to Europe, because for him, the level of subjective religiosity remained high on the continent. ${ }^{177}$

In Stark's view, the fact that the majority still believed in God but did not fill the need to participate in religious institutions was explained by two factors. First, even in the Middle Ages, the majority of the European population was only nominally converted. The missionary process was carried out by the conversion of the King instead of the evangelization of the population. Immediately after the King's conversion, the nation governed by him was canonized as a saint. In the process of becoming Christian by decree, people were baptized but continued to sacrifice to their pagan gods in private. Therefore, he wrote, the Golden Age of medieval religiousness was highly subjective, in which people embraced not only the Christian faith but also animistic beliefs. The masses were never really active in their church membership, but as Christians or animists, they continued to believe, and therefore, societies remained religious. ${ }^{178}$

\footnotetext{
${ }^{175}$ Stark, “Secularization, RIP,” 251-52.

176 Stark, "Secularization, RIP," 253.

177 Stark, "Secularization, RIP," 254.

${ }^{178}$ Stark, “Secularization, RIP,” 260-61.
} 
Second, religious institutions lost their influence with the process of industrialization, urbanization, and rationalism, so that the majority of the population began to practice belief behavior in private, independent of religious institutions. Stark called this "believing, without belonging." 179 For example, he cited Iceland, considered the first fully secularized nation on earth, based on its empty churches, with only 2 percent of the population attending weekly worship services. However, he showed there is a high level of home religion, as well as baptisms, in the country and almost all marriages are in churches. Moreover, 82 percent of the population said they prayed sometimes, and 25 percent said they prayed often. Only 2.4 percent said they were convinced atheists. ${ }^{180 ~ " P e r h a p s ~ r e l i g i o n ~ i s ~ n e v e r ~ s o ~ r o b u s t ~ a s ~ w h e n ~ i t ~ i s ~ a n ~}$ underground church," Stark concluded. ${ }^{181}$

The Stark and Bainbridge reward theory states that "human seek what they perceive to be rewards and avoid what they perceive to be costs." ${ }^{\prime 182}$ That is, we move toward receiving benefits or rewards that are usually tangible, such as good quality of life and good health. Within the economy of religion, the rewards are generally less tangible, such as forgiveness, peace, and eternal life, among others. ${ }^{183}$ To Stark and Bainbridge, religion is sustained by the fact that humans "greatly desire rewards which are not to be found in this material world of scarcity, frustration and death." 184

${ }^{179}$ Stark, "Secularization, RIP,” 263.

${ }^{180}$ Stark, "Secularization, RIP,” 264.

${ }^{181}$ Rodney Stark, "Must All Religions Be Supernatural?" in The Social Impact of New Religious Movements, ed. Bryan Wilson (New York: Rose of Sharon Press, 1981), 175.

${ }^{182}$ Stark and Bainbridge, Theory of Religion, 161.

${ }^{183}$ Rodney Stark and William Sims Bainbridge, "Of Churches, Sects, and Cults: Preliminary Concepts for a Theory of Religious Movements," Journal for the Scientific Study of Religion, 18, no. 2 (June 1979): 121, https://www.jstor.org/stable/1385935?seq=1\&cid=pdf-reference\#references_tab_contents.

${ }^{184}$ Stark and Bainbridge, Theory of Religion, 312. 
The authors explained that when rewards are rare or unavailable, there is a tension between those who are dominant and those who are peripheral in the social or religious structure. Under these circumstances, humans seek compensators, "an intangible promise which substitutes for the desired reward." 185 That is, the compensators are subjective values accepted by faith, such as heaven, eternal life, resurrection, among others. For the authors, "solutions to questions of ultimate meaning seem only available in the form of compensators," in the "assumption of the existence of the supernatural." 186

Stark and Bainbridge saw a relationship between the process of secularization and the emergence of sects and cults, based on the human need for rewards. When churches remain strong as a tradition but have their credibility eroded by secularization, they weaken their belief system and become syncretic with culture, leading people not to perceive them as sources of spiritual rewards. In this case, people promote revival and establish sects in search of compensators in an attempt to return to their original spiritual commitments or regain a purer form of the prevailing tradition. ${ }^{187}$

The second form of compensator is cults with more radical religious innovation, and they occur when secularization makes the predominant religious tradition unviable. In this case, when faith in the religious tradition has attenuated dramatically and the traditional churches have become weak, cults will arise to meet the continuing demand. Over time, these new cults may become new predominant religious traditions. ${ }^{188}$

\footnotetext{
${ }^{185}$ Stark and Bainbridge, Theory of Religion, 120.

${ }^{186}$ Stark and Bainbridge, Theory of Religion, 121.

${ }^{187}$ Stark and Bainbridge, Theory of Religion, 143-49.

188 Stark and Bainbridge, Theory of Religion, 155-68.
} 
Stark and Bainbridge pointed out that while both sects and cults are deviant religious groups that cause high tension in their sociocultural environment, they differ in how they originate. Sects are split off from an existing religious body with the intent to reform and recover the old tradition that has been lost, and generally claim to be the authentic version of the faith. "Sects are breeds of a common species ... being schismatic, are embodied in a religious organization." ${ }^{189}$ Cults have no connection with any existing religious group in the society in question. They are innovative movements that may come from another society or from within a society, but always present to the current culture a new revelation or insight that justifies their claim to be different. "Cults are a different species and occur by mutation or migration." 190 For Stark and Bainbridge, Europe provides evidence that the search for compensators, in the spiritual domain, remains reliably constant despite the decline of the churches. ${ }^{191}$

In their studies of recruitment theories, Stark and Bainbridge concluded that networks are the number one tool for effective recruitment for cults, sects, and conventional religions, as well as preventing desertions. For them, interpersonal ties are far more effective than ideologies themselves in sustaining commitments. They also emphasized that the reward system is fundamental to the recruitment process through networking. People are attracted when their needs are met and their deprivation reduced, whether in the affective, physical, emotional, or spiritual realms. ${ }^{192}$ They concluded that "social networks are direct rewards." 193

${ }^{189}$ Stark and Bainbridge, "Of Churches, Sects and Cults," 126.

${ }^{190}$ Stark and Bainbridge, "Of Churches, Sects and Cults," 126.

${ }^{191}$ Stark and Bainbridge, Theory of Religion, 264, 266.

${ }^{192}$ Rodney Stark and William Sims Bainbridge, "Networks of Faith: Interpersonal Bonds and Recruitment to Cults and Sects," American Journal of Sociology 85, no. 6 (May 1980): 1392-93, https://www.jstor.org/stable/2778383.

${ }^{193}$ Stark and Bainbridge, "Networks of Faith," 1394. 
Therefore, the emergence of sects and new cults from the perspective of the human search for rewards and compensators characterizes secularization in Stark and Bainbridge`s view. They wrote that the characteristics of religions will change greatly, but religion will continue undiminished. ${ }^{194}$

\section{Grace Davie (1946- )}

A significant element of Grace Davie's view on secularization is "believing without belonging." In the beginning applied only to the United Kingdom, this expression came to represent the idea that religion and values are not disappearing due to the influence of secularism, especially among young people, but undergoing reformulations. ${ }^{195}$ Davie argued for the credibility of this idea through statistics related to beliefs and belonging indicators, ${ }^{196}$ as well as more recent formulations, that demonstrate the persistence of institutional religion. ${ }^{197}$ According to her, this is a feature primarily found among the more modestly educated Western population, ${ }^{198}$ and it is similar to the distinction that many make between spirituality and religion, showing the possibility of developing personal belief regardless of relationship to religious institutions. ${ }^{199}$

${ }^{194}$ Stark and Bainbridge, Theory of Religion, 312.

195 Grace Davie, “Believing without Belonging: Is This the Future of Religion in Britain?” Social Compass 37, no. 4 (1990): 462.

${ }^{196}$ Grace Davie, "Patterns of Religion in Western Europe: An Exceptional Case," in The Blackwell Companion to Sociology of Religion, ed. R. K. Fenn (Oxford: Blackwell, 2001), 265-70.

${ }^{197}$ Grace Davie, "The Persistence of Institutional Religion in Modern Europe," in Peter Berger and the Study of Religion, ed. L. Woodhead (London: Routledge, 2001). 2000), 69.

198 Grace Davie, Religion in Modern Europe: A Memory Mutates (New York: Oxford University Press,

199 Grace Davie, The Sociology of Religion (Los Angeles: SAGE, 2007), 44. 
Davie explained that in the United Kingdom, more and more people of all classes want to believe, but passively, without getting involved in religious practice; it seems that middle-class and higher-educated people are more inclined to associate belief with religious practice through a belonging form. Already less educated people seem to have difficulty placing belief within a practical, institutional, or liturgical context. ${ }^{200}$ For her, the persistence of the sacred in contemporary society, despite the decline in church attendance, is a feature that needs to be studied. ${ }^{201}$

Davie drew attention to "intriguing new patterns of belief and behavior" that have begun to emerge in the Western world, especially among young people. ${ }^{202}$ She pointed out that in Europe, this new religious behavior is more evident, especially where the institutional church is weak, with emphasis on the immanence of God as a being manifesting in the individual as opposed to the transcendent and distant God, as well as the conviction that life goes on after death. ${ }^{203}$ In this case, as religious institutionalism declines, spirituality increases, but in innovative ways, opening new possibilities in the relationship with the transcendent. ${ }^{204}$

However, Davie pointed out that on the European continent, there was evidence that religious institutions continued to influence many aspects of the individual and collective life of the population, and church buildings continued to have symbolic importance in communities. ${ }^{205}$ Relatively few Europeans attended church with any regularity, but many were strengthened by

\footnotetext{
${ }^{200}$ Davie, Religion in Modern Europe, 107.

${ }^{201}$ Grace Davie, Religion in Britain Since 1945 (Cambridge: Blackwell, 1994), 94.

${ }^{202}$ Davie, Sociology of Religion, 98.

${ }^{203}$ Davie, Sociology of Religion, 98-99, 140.

${ }^{204}$ Davie, Sociology of Religion, 99.

${ }^{205}$ Davie, Sociology of Religion, 140-41.
} 
the presence of church buildings in their locality, and explicitly protested when a building was threatened with closure. They continued to view churches as public services, maintained for the common good. ${ }^{206}$

For Davie, there are at least four reasons why people prefer to stay away from churches, although many do not want to get rid of them. First, they associate the church with the historical use of power and dominion, which in many cases was arbitrary and insane. ${ }^{207}$ Second, she observed that access to religious content through television, radio, and other technological means of mass communication, in a religious market context, allows people to settle for a religious experience without a visible community, or through what she called the "air church." ${ }^{208}$ Third, the many options for distraction and leisure offered by contemporary industrial and technological society occupy people`s daily lives. ${ }^{209}$ Fourth, is what she called "vicarious religion"— "the notion of religion performed by an active minority but on behalf of a much larger number, who implicitly at least not only understand but quite clearly approve of what the minority is doing." 210 For her, vicarious religion manifests itself explicitly in situations of significant loss and impact. ${ }^{211}$ As an example, she cited the death of Princess Diana and other public tragedies when a significant number of people in Britain instinctively sought out churches. Davie pointed out that such occasions lead people to realize that gestures of individual mourning are not enough, giving way to public rituals in established churches as the place to meet the most profound demands of

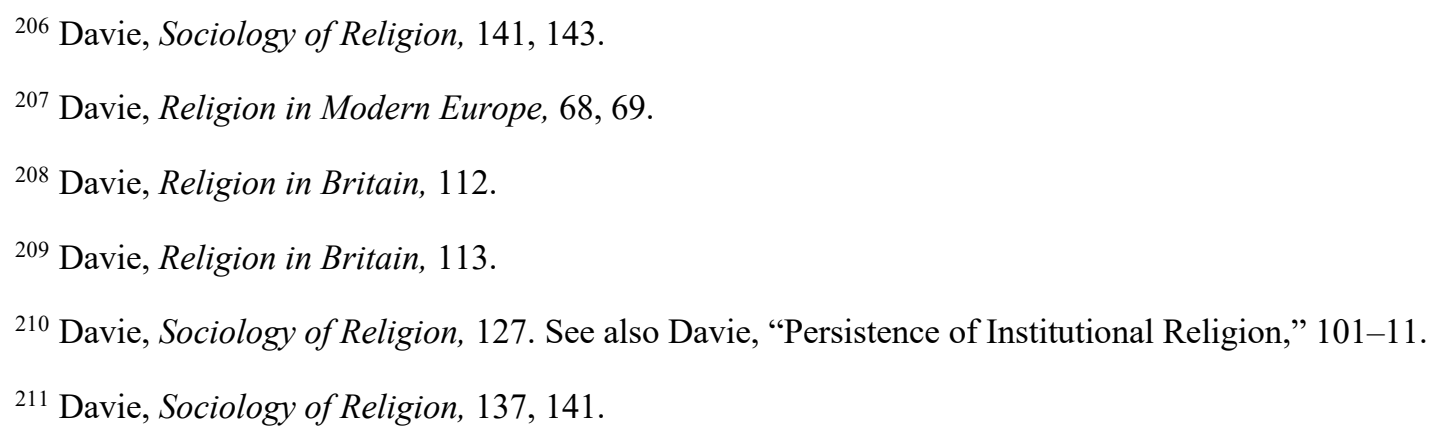


human existence. The majority of the population at such times not only understands but also approves what the minority does when it seeks out churches in response to these questions, and still feels represented by that minority. ${ }^{212}$

Faced with this new scenario of believing without belonging, but at the same time still maintaining a certain sympathy and respect for religious institutions, Davie made three considerations: first, following Durkheim's line, she attested that religion would not disappear, nor would there be a society wholly secularized at all. For her, some belief will likely continue alongside more secular understandings of life. ${ }^{213}$ Second, she theorized that in the context of church-state separation and installed democracy, the relationship between church and society would be one of personal choice or consumption, where churches would become voluntary organizations governed by a market process, among many other existing organizations. ${ }^{214}$ Finally, Davie pointed out that designing appropriate ministerial strategies for this continually changing and undefined scenario is a problematic but central task for religious professionals. ${ }^{215}$ Therefore, religiosity marked by the experience of believing without belonging is Davie's selected characteristic of secularization in the contemporary world.

\section{Laurence Iannaccone (1954- )}

A significant element that characterizes Iannaccone's understanding of secularization is the theory of "religious mobilization" - an environment of freedom and religious pluralism. $\mathrm{He}$

\footnotetext{
${ }^{212}$ Davie, Sociology of Religion, 127, 128.

${ }^{213}$ Davie, Sociology of Religion, 98, 140.

${ }^{214}$ Davie, Sociology of Religion, 126, 143, 149, 163.

${ }^{215}$ Davie, Sociology of Religion, 139.
} 
developed this theory along with Stark. ${ }^{216}$ According to them, Comte coined the term sociology expecting this new science to soon replace religion as the basis for moral judgment, culminating with the secularization process. For Stark and Iannaccone, this idea of the disappearance of religion was probably the single social scientific proposition most widely accepted in the world, and lasted most of the twentieth century. However, they explained that faith in the secularization thesis, meaning religious elimination, has been declining, especially among sociologists and social historians in the religious field. ${ }^{217}$

Stark and Iannaccone contradicted some of the premises used by those who defend the secularization of Europe as a fait accompli. First, they noted that the "universal piety" that supposedly existed in Europe in the Middle Ages, and which is contrasted with the current secular state of the continent, did not occur. They cited studies demonstrating great apathy, heterodoxy, and agnosticism at the time, as well as contempt from religious leaders toward the peasants who were the majority of the population. ${ }^{218}$ They pointed to neglect of pastoral duty and a high rate of promiscuity among Catholic priests, low religious participation of the masses, and a highly animistic religiosity in the period. ${ }^{219}$

Similarly, Stark and Iannaccone countered the idea that colonial New England in the United States was a symbol of faith. They pointed out that New England was relatively unchurched, with low rates of religious affiliation and attendance at worship services, as was the

\footnotetext{
${ }^{216}$ Rodney Stark and Laurence R. Iannaccone, "Supply-Side Reinterpretation of the 'Secularization' of Europe," Journal for the Scientific Study of Religion 33, no. 3 (1994): 230-52. See also Laurence Iannaccone, "The Consequences of Religious Market Structure: Adam Smith and the Economics of Religion," Sage Journals: Rationality and Society 3, no. 2 (April 1991): 156-77.

${ }^{217}$ Stark and Iannaccone, "Supply-Side Reinterpretation," 249; Laurence R. Iannaccone, "Introduction to the Economics of Religion," Journal of Economic Literature 36 (September 1998): 1468-74.

${ }^{218}$ Stark and Iannaccone, "Supply-Side Reinterpretation," 242, 249.

${ }^{219}$ Stark and Iannaccone, "Supply-Side Reinterpretation," 242-43.
} 
rest of the country. ${ }^{220}$ For them, both medieval Europe and New England were highly sacralized societies, the former with the power of states imposing a hegemonic religion and the latter having Puritan norms enshrined in legal codes, which gave the illusion of universal piety, but with low participation rates. ${ }^{221}$ However, the authors wrote, a sacralized society does not necessarily mean a universally religious society, just as a desacralized society does not necessarily mean a secularized society. For them, a society becomes sacralized when there is a hegemonic religion, imposed by the force of the state and exerting its influence on other institutions, from the family to politics; the institutions are imbued with religious, rhetorical, and ritual symbols. ${ }^{22}$ They argued that the spiritual standard of a society should be measured not by organized religious behavior but by subjective religious attitude; the former varies widely, but the latter is stable and permanent. ${ }^{223}$

From this perspective, Stark and Iannaccone proposed the theory of religious mobilization, according to which a model of the religious economy ${ }^{224}$ should focus on the

\footnotetext{
${ }^{220}$ Stark and Iannaccone, “Supply-Side Reinterpretation,” 243-44.

${ }^{221}$ Stark and Iannaccone, "Supply-Side Reinterpretation,” 244.

222 Stark and Iannaccone, "Supply-Side Reinterpretation," 234.

${ }^{223}$ Stark and Iannaccone, "Supply-Side Reinterpretation," 232.
}

224 "Religious economy consists of all the religious activity going on in any society. Religious economies are like commercial economies in that they consist of a market of current and potential customers, a set of firms seeking to serve that market, and the religious "product lines' offered by the various firms." Stark and Iannaccone, "Supply-Side Reinterpretation," 232. Adam Smith laid the foundation for an economic analysis of religion. For him, religious leaders were motivated by personal interests, just like secular workers, and market forces restricted churches as much as secular corporations. Smith also wrote that when religion faces the benefits of competition, the burdens of monopoly, and the risks of government regulation, it receives the same impact as the general sectors of the economy. Adam Smith, An Inquiry into the Nature and Causes of the Wealth of Nations (New York: Modern Library, 1965), 740-66. Contemporary studies on the economics of religion began with Azzi and Ehrenberg in 1975, who proposed the A-E model, relating family production to church attendance. The main conclusions they reached are: First, human beings place their goods and time at the service of religious and secular commodities, always seeking to maximize the usefulness of the present life and the afterlife. Second, for them, religious participation has as its primary objective the conquest of postmortem goods, although they also recognize the immediate benefits of religious life. Third, families and people with higher educational attainment and higher incomes have higher religious participation in terms of financial contribution and less intense involvement in church activities. These 
behavior of religious firms ${ }^{225}$ rather than solely on religious consumers. ${ }^{226}$ In this case, denominations function individually as religious firms and collectively as a religious market. ${ }^{227}$ According to their theory, the degree of religious freedom in a society determines the degree of religious pluralism that exists. The less the religious economy is regulated, the higher the pluralism or number of firms active in that religious economy, operating in a competitive process. Furthermore, the higher the number of active religious firms having a significant market share, the more pluralism and specialization emerge - "the firm caters to the special needs and tastes of specific market segments." ${ }^{228}$ Based on regular divisions of society such as class, age, gender, health, and varied needs and tastes, different segments will be formed to meet the demands of the religious market. ${ }^{229}$

families depend more on the services of professional ministers, teachers, choir directors, and janitors, and require shorter meetings and rituals. Similarly, families and people with lower incomes contribute less financially but have a more significant share in church activities as well as in the production of religious commodities and services. To the authors, this is a kind of substitution between time and money devoted to religion. Fourth, because of this inverse relationship between money and time devoted to religion, they attested that working-age people, whose primary purpose is to earn money, have less participation in religious activities, increasing participation as they age. Similarly, women (especially widows) have more intense and constant religious participation than men. See Corry Azzi and Ronald G. Ehrenberg, "Household Allocation of Time and Church Attendance," Journal of Political Economy 83, no. 1 (1975): 27-56. Some other religious economy studies that have been based on and refined the AE model are Shoshana Neuman, "Religious Observance within the Human Capital Framework: Theory and Application," Applied Economics 18, no. 11 (1986): 1193-1202; Holley Ulbrich and Myles Wallace, "Church Attendance, Age, and Belief in the Afterlife: Some Additional Evidence," Atlantic Economic Journal 11, no. 2 (1983): 44-51; Dennis H. Sullivan, "Simultaneous Determination of Church Contributions and Church Attendance," Economic Inquiry 23, no. 2 (1985): 309-20; Ronald G. Ehrenberg, "Household Allocation of Time and Religiosity: Replication and Extension," Journal of Political Economy 85, no. 2 (1977): 415-23; David A. Vaus, "Workforce Participation and Sex Differences in Church Attendance," Review of Religious Research 25, no. 3 (1984): 247-56.

225 "Religious firms are social enterprises whose primary purpose is to create, maintain and supply religion to some set of individuals." Stark and Iannaccone, "Supply-Side Reinterpretation," 232.

${ }^{226}$ Stark and Iannaccone, "Supply-Side Reinterpretation," 232; Laurence R. Iannaccone, "Deregulating Religion: The Economics of Church and State," Economic Inquiry 35 (April 1997): 350-52, 362; Laurence R. Iannaccone, "Religious Markets and the Economics of Religion," Social Compass 39, no. 1 (March 1992): 123-31.

\footnotetext{
${ }^{227}$ Iannaccone, "Introduction to the Economics," 1498.

${ }^{228}$ Stark and Iannaccone, "Supply-Side Reinterpretation," 232.

${ }^{229}$ Stark and Iannaccone, "Supply-Side Reinterpretation," 233.
} 
For Iannaccone, the more competitive and pluralistic the religious economy, the higher the degree of participation or involvement of people. On the other hand, if one or a few statesupported firms dominate the religious economy, the overall number of participants will tend to be lower. ${ }^{230}$ "Measure of piety, including frequency of prayer, belief in God, and confidence in religion, is greater in countries with numerous competing churches than in countries dominated by a single established church." ${ }^{231}$ He also pointed out that churches that are financially maintained and government-regulated have a consistently lower average level of belief and participation than small denominations operating in a free and competitive religious market system. Similarly, the more religious diversity, the higher the rate of religious affiliation and attendance at worship meetings. ${ }^{232}$

One primary reason is that because of the nature of religious products, which are intangible and point to distant and future goals, vigorous marketing activity is required to achieve high levels of consumption. Nevertheless, when there is a religious monopoly, licensed firms tend to be ineffective, because it is precisely competition that generates the need for specialization and allows for a variety that can appeal to more customers. ${ }^{233}$ Therefore, Iannaccone wrote that a competitive market more adequately satisfies consumer preferences than a monopolized market, and also, religion has more social vitality in a society of religious

${ }^{230}$ Iannaccone, “Consequences of Religious Market Structure,” 172.

${ }^{231}$ Iannaccone, "Introduction to the Economics," 1486.

${ }^{232}$ Iannaccone, "Introduction to the Economics," 1486; Iannaccone, "Consequences of Religious Market Structure," 172.

${ }^{233}$ Iannaccone, "Introduction to the Economics," 1491. 
freedom. ${ }^{234}$ From this perspective, he argued that in matters of religion, the maxim of civil governments should be used in reverse: "Divided we stand, united, we fall.". ${ }^{235}$

Iannaccone concluded that when a society becomes secular or without an official religion, it gradually becomes desacralized; this does not mean secularization in the sense of extinction of religion, but a process of readjustment to religious pluralism capable of providing high participation. Considerable desacralization tends to occur before there is sufficient pluralism capable of religiously mobilizing society. ${ }^{236}$

Secondly, several factors may slow the development of vigorous pluralism, as the deregulation of the religious economy is more apparent than real. Rulers tend to continue to favor hegemonic religion, even after a legal position in favor of religious freedom. Tradition or cultural inertia often delays acceptance of new religious options as usual and legitimate. Moreover, if the new religious options are branches of foreign religious groups, it takes time for missionaries to develop ties with the local people..$^{237}$

Third, Iannaccone argued that the degree of religiosity should be measured based mainly on subjective religion. For him, in both medieval Europe and New England, the average population was probably religious in some sense, even if it was a vague religiosity, or included something magical and animistic. He pointed out that the theory of secularization erred in relying 233.

${ }^{234}$ Iannaccone, "Deregulating Religion," 351-52; Stark and Iannaccone, "Supply-Side Reinterpretation,"

${ }^{235}$ Iannaccone, "Introduction to the Economics," 1488.

${ }^{236}$ Stark and Iannaccone, "Supply-Side Reinterpretation,” 234-35.

${ }^{237}$ Stark and Iannaccone, "Supply-Side Reinterpretation," 235. 
solely on participation in religious organizations and not taking into account subjective religiosity. ${ }^{238}$

Fourth, Iannaccone presented the growth of Latin American Protestantism and church membership in the United States as examples of how religious pluralism results in more significant mobilization and religious participation. In the same way, he believed this was the path to more significant religious commitment and mobilization in Europe. ${ }^{239}$ Like Smith, Iannaccone pointed out that religious competition generates "not only more religion, but also better religion." 240

Finally, Iannaccone stated that it seems clear that the secularization thesis has failed, since "humans do not live by sociological bread alone." ${ }^{241}$ The future of religion is not extinction, but to continue its fluctuating process of ups and downs, although subjective religiosity seems to vary less. ${ }^{242}$ From this perspective, Iannaccone advocated that the twenty-first century would be the true age of faith. ${ }^{243}$

Therefore, religious mobilization, provided by a free and plural environment characteristic of a competitive religious market, is a selected and striking element of secularization in Iannaccone's view. For the author, it is in this context of a free religious market that there will be higher affiliation, as well as religious participation.

\footnotetext{
238 Stark and Iannaccone, "Supply-Side Reinterpretation,” 245-46.

239 Stark and Iannaccone, "Supply-Side Reinterpretation," 245-47.

${ }^{240}$ Iannaccone, "Introduction to the Economics," 1489.

${ }^{241}$ Stark and Iannaccone, "Supply-Side Reinterpretation,” 250.

${ }^{242}$ Stark and Iannaccone, "Supply-Side Reinterpretation,” 250.

${ }^{243}$ Iannaccone, “Consequences of Religious Market Structure,” 174.
} 


\section{Summary of Durkheim and Followers}

According to Durkheim and his followers examined above, elements that characterize secularization in the contemporary period are the eternal, and at the same time changing, nature of religion; the emergence of sects and new cults; the human pursuit of rewards and compensators; a religious experience characterized by the attitude of believing without belonging; and finally, religious mobilization that comes from a competitive religious market.

\section{Elements of Secularization Theories of Independent Scholars}

\section{Peter Berger (1929-2017)}

Considered the most sophisticated modern proponent of the secularization thesis, ${ }^{244}$ Berger argued until the 1960s that the process of secularization would make the world less religious. ${ }^{245}$ In that context, he thought that secularization and modernization went hand in hand, so that as modernization grew, so would secularization. ${ }^{246}$ He predicted that "by the 21 st century, religious believers are likely to be found only in small sects, huddled together to resist the worldwide secular culture." ${ }^{247}$ However, Berger later acknowledged that the theory of secularization erred in its prediction of the weakening of religion. He wrote, "It became more and more apparent that the empirical data contradicted the theory. With some exceptions, notably

244 Stark, "Secularization, RIP," 251.

${ }^{245}$ Peter L. Berger, The Sacred Canopy: Elements of a Sociological Theory of Religion (New York: Open Road Integrated Media, 1966), 203-4. (1997): 974.

${ }^{246}$ Peter L. Berger, “Epistemological Modesty: An Interview with Peter Berger,” Christian Century 114

${ }^{247}$ Peter L. Berger, “A Bleak Outlook Is Seen for Religion,” New York Times, April 25, 1968, 3. 
Europe and an international intelligentsia, our world is anything but secular; it is as religious as ever, and in places more so." 248

Berger explained the effect of secularism on religion in today's societies through the following chain of successive effects: modernism spawned secularism, which in turn brought about religious pluralism, which gave rise to relativism and at the same time fundamentalism as two opposing forces. ${ }^{249}$ For Berger, insofar as secularism breaks the hegemonic religious tradition and drives the state to ensure the existence and proliferation of different religious groups, the environment is ripe for a pluralistic religious situation. ${ }^{250}$ Therefore, religious pluralism is a prominent element that characterizes secularization in Berger`s perspective.

For Berger, modernization brought about a profound transformation in the human condition. It multiplied opportunities for choice, generating a pluralistic environment, which he describes as "the social situation in which people with different ethnicities, worldviews, and moralities live together peacefully and interact with each other amicably." ${ }^{251} \mathrm{He}$ explained that this process of peaceful tolerance in an environment of disagreement is only possible because pluralism generates a permanent experience of relativization. First, pluralism produces what he calls "cognitive contamination" or a kind of progressive numbness in the face of contradiction, so that one gradually accepts with less shock what one previously did not tolerate, and the mind previously ruled by absolute values becomes used to an experience of relativization. ${ }^{252}$

\footnotetext{
${ }^{248}$ Peter L. Berger, The Many Altars of Modernity: Toward a Paradigm for Religion in a Pluralist Age (Boston, MA: Walter de Gruyter, 2014), x.

${ }^{249}$ Peter L. Berger and Anton Zijderveld, In Praise of Doubt: How to Have Convictions Without Becoming a Fanatic (New York: Harper Collins, 2009), 147-48.

${ }^{250}$ Berger, The Sacred Canopy, 296-97, 303.

${ }^{251}$ Berger, Many Altars, 1.

${ }^{252}$ Berger, Many Altars, 2-3.
} 
"Pluralism relativizes and thereby undermines many of the certainties by which human beings used to live," 253 he stated.

Although Berger asserted that a certain degree of pluralism has always existed, and is a necessary condition for fostering innovation and motivating questioning, ${ }^{254}$ he maintained that contemporary religious pluralism is unique in its intensity and extent because it results from powerful modern forces, including urbanization and migration, allowing people from different backgrounds to live together in the same environment, as well as literature and mass communication that allow access to the beliefs and values of people everywhere. According to him, this situation has challenged those institutions with absolute truth claims. ${ }^{255}$

Berger pointed out that relativism can be found at different levels of sophistication, from relativistic pragmatic actions with kind or nasty tendencies that say "I respect you despite our differences," or "You think this way because you are an asshole, and I am not," down to the level of sophisticated theories designated by Nietzsche as "the art of mistrust," such as postmodernism. ${ }^{256}$ For Berger, the primary method behind these theories is to translate claims of virtue or truth into expressions that have underlying interests that have nothing to do with virtue

\footnotetext{
${ }^{253}$ Berger, Many Altars, 9.

${ }^{254}$ Berger and Luckmann, Social Construction of Reality, 144.

${ }^{255}$ Peter Berger, Questions of Faith: A Skeptical Affirmation of Christianity (Malden, MA: Blackwell,
} 2004), 14-15. See also Harvey Cox, The Secular City (Princeton, NJ: Princeton University Press, 2013), xxxv, xxxvii-xxxix. In this book, Cox used the expression "secular city" as a metaphor of the emerging urban world, and also pointed out that new technologies and an accelerated process of religious mutation and hybridization are core characteristics of the secularization and urbanization phenomenon, making necessary a new theology with secular/religious focus.

${ }^{256}$ Berger, Many Altars, 11. Postmodernism is the philosophical and sociological movement that began in the twentieth century as a reaction to the optimism of the modern period with an emphasis on reason and science as the solution for humanity. The greatest thinkers of the postmodern movement are Jacques Derrida, with his emphasis on deconstruction; Michel Foucault, who fought against entrenched political power; Richard Rorty, who advocated the relativism of truth; and Stanley Fish, with his idea of community interpretation. See Millard J. Erickson, Truth or Consequences: The Promise and Perils of Postmodernism (Downers Grove, IL: Intervarsity Press, 2001), 111-82. 
or truth. Generally, the underlying interests are related to the gain of power, wealth, and pleasure, with Machiavelli, Marx, and Freud as significant representatives of these worldviews. ${ }^{257}$

Berger also pointed out that "relativism undermines the moral consensus without which no society can survive," and stated that it is the only major challenge for all the traditions and religious communities of modernism. ${ }^{258}$ For him, the three biggest challenges that pluralism and relativism present to religion are the individualized perspective of religion, religion in a market context, and the relativization of religious content. ${ }^{259}$

Berger stated that individualization of religion represents a reinterpretation of the meaning of religion, which no longer refers to the cosmos, or history, individual existence, or psychology, being legitimized on an empirical basis rather than based on cognitive content. In this case, people "discover" religion within subjective consciousness, he says, through the socialpsychological process of demonopolization of faith. ${ }^{260}$ Berger pointed out that the proliferation of an independent religiosity dissociated from religious institutions was first defended by Bonhoeffer, whose ideas were widely used to give legitimacy to the new approach of Christianity without religion. ${ }^{261}$ In this new context, religion becomes a subject of free subjective choice and individual conscience, being relevant primarily in the context of private life. ${ }^{262}$ In a

\footnotetext{
${ }^{257}$ Berger, Many Altars, 11.

${ }^{258}$ Berger, Many Altars, 15.

${ }^{259}$ Berger, The Sacred Canopy, 271-80.

${ }^{260}$ Berger, The Sacred Canopy, 275-77.
}

${ }^{261}$ In his correspondence from prison, Bonhoeffer developed the notion of "religionless Christianity," or the idea that God is deliberately calling us in the modern period to a form of Christianity that does not depend on the premise of religion, just as St. Paul was calling men in the first century to a form of Christianity that did not depend on the premise of circumcision. Dietrich Bonhoeffer, Prisoner for God: Letters and Papers from Prison (New York: Macmillan, 1953), 123.

${ }^{262}$ Bonhoeffer, Prisoner for God, 251-52, 316. 
sense, each person in the process of religious reflection becomes a theologian, because what matters is the pragmatic utility of religion, and professionals no longer build theology. ${ }^{263}$

From the perspective of religion in a market context, Berger explained that, as religious firms, churches start to produce religious products, whose content is guided by fashion, aiming to fit with the secular taste and conscience of people. The plausibility of religious products is subject to subjective criteria and consumer control, adapting to customer needs and pressures. The keywords are "opinions," "feelings," and "preferences."264

Berger attested that religious subjectivity in this new market context leads to the flexibility of theology and the disfigurement of the content of religion. The referential is shifted from the cognitive content of faith to customer preference and fashion. Religion, as a consequence, enters a crisis of credibility, and there is a multiplication of new structures competing with each other for the production of the most attractive religious content. ${ }^{265}$

According to Berger, another consequence of pluralism is fundamentalism, which is born as a counterpoint to relativism. He argued that fundamentalism, as used today, refers to an empirically determinable reality in certain respects. First, fundamentalism is a reactive phenomenon that, in the contemporary context, manifests itself in reaction to the relativizing effect of modernity. ${ }^{266}$ Second, fundamentalism arises when tradition is entirely contested or lost. The difference between fundamentalism and traditionalism, according to Berger, is that the traditionalist is tolerant of those who do not share the same worldview, seeing them as those who

\footnotetext{
${ }^{263}$ Berger, Questions of Faith, 4.

${ }^{264}$ Berger, Questions of Faith, 251-52, 268, 271-73.

${ }^{265}$ Berger, Questions of Faith, 180-81, 220-25.

${ }^{266}$ Berger and Zijderveld, In Praise of Doubt, 147, 151.
} 
do not see the obvious. However, the fundamentalist sees these people as a severe threat to certainty gained with much effort, who must be converted or segregated, and in extreme cases, expelled or even exterminated. ${ }^{267}$ In short, fundamentalism is an attempt to restore the premise of a lost tradition, viewed as fundamental. ${ }^{268}$

Berger pointed out that fundamentalism generally manifests itself in two ways. The first is that the fundamentalists try to take over the whole society, imposing their creed on it, through the model of the reconquest. It is in this perspective that totalitarian states are formed, for example, maintaining control against all threats to the fundamentalist worldview. ${ }^{269}$ The second way is to give up imposing their creed on society and move away to build a smaller community that guarantees the maintenance of their worldview, giving rise to the sectarian or subcultural model of fundamentalism. To Berger, the Amish, the Shakers, and the Mormons of Utah are examples of this second model. ${ }^{270}$

In his reflection on pluralism, Berger sought to distance himself from two extreme consequences of the phenomenon: relativism and fundamentalism. While relativism imposes an excess of doubt on a stable society, on the other hand, fundamentalism brings the danger of insufficient doubt. For him, it was possible to avoid extremes in this context by having an experience of faith that can positively deal with differences. ${ }^{271}$

Berger pointed out that religious pluralism creates a great deal of insecurity in the face of a confusing world full of interpretive possibilities, because most people need a world that

\footnotetext{
${ }^{267}$ Berger and Zijderveld, In Praise of Doubt, 148-49.

${ }^{268}$ Berger and Zijderveld, In Praise of Doubt, 149-50.

${ }^{269}$ Berger and Zijderveld, In Praise of Doubt, 153-54.

${ }^{270}$ Berger and Zijderveld, In Praise of Doubt, 154, 160, 162.

${ }^{271}$ Berger and Zijderveld, In Praise of Doubt, 169, 175-76.
} 
provides them with security, free from questioning. Thus, even at present, people seek support in communities that are free of cognitive disagreement, offering certainty through stable doctrines and codes of behavior. ${ }^{272}$

For him, from a philosophical perspective, the challenge of pluralism can be defined as maintaining convictions without dissolving them into pure relativity, and without gathering them into the false absolutes of fanaticism. This is a difficult challenge, but not impossible. ${ }^{273}$ Therefore, the main element of secularization in Berger's view is religious pluralism, and with it the relativization of religious content, as well as the individualized religious perspective.

\section{Charles Taylor (1931- )}

Taylor performed a historical analysis of religious development from the pre-modern period to the present, based on Durkheim's concept of the permanence of religion as a factor of social organization, in order to clarify the contemporary state of authenticity that dominates the religious scene. He argued that every human being has a conventional religious capacity and is seeking an experience of happiness and completeness to make sense of life. However, he theorized that in "enchanted" times and places, where religion is all-encompassing and unquestionable, people are infected and allowed to be influenced by external entities such as spirits and deities. On the other hand, as disenchantment increases in any society, the individual becomes more "buffered." 274

With this approach, Taylor devised three religious' types: first, the "paleo-Durkheimian," in pre-modern societies or the "enchanted world," in which "the force which inheres in social

\footnotetext{
272 Berger and Luckmann, Modernity, Pluralism, 54.

${ }^{273}$ Peter L. Berger, Una gloria remota. Avere fede nell'epoca del pluralism (Bologna: Il Mulino, 1994), 49.

${ }^{274}$ Taylor, A Secular Age.
} 
obligations comes from the sacred of which the church is guardian and articulator." The second type, the "neo-Durkheimian," appears in nations where religion is central to political identity. In this case, religion and politics mix, forming the so-called "civil religion," with a secure connection to the civilizational order, under the influence of a disenchanted view. The "postDurkheimian" refers to contemporary pluralistic societies in which people can conduct spiritual searches according to their inclinations, without reference to orthodoxies and hierarchies or an overarching social framework. ${ }^{275}$

Based on the contemporary or post-Durkheimian religious scenario, Taylor described the so-called "ethics of authenticity," which can be considered a preponderant element of his theory of secularization. The ethics of authenticity argues that all human beings are ontologically autonomous, and therefore each person must realize humanity in a specific and personal way. ${ }^{276}$ According to Taylor, the ethics of authenticity was born in the late eighteenth century in Europe among elites, but became widespread in the northern hemisphere in the second half of the twentieth century. It was adopted in the United States with the slogan "To be what one is."277

In contemporary culture, authenticity is related to the defense of individualism, as well as the independence of will based on the modern notion of human dignity and the universal and egalitarian sense of value. It is the politics of equality of recognition, in which people have the chance to develop their own identity and to form relationships based on love. ${ }^{278}$ The ethics of authenticity also places morality as something to be defined within each person, as well as

275 Taylor, A Secular Age, 512-31.

${ }^{276}$ Charles Taylor, The Ethics of Authenticity (Cambridge, MA: Harvard University Press, 2003), 50.

${ }^{277}$ Charles Taylor, "Características e interfaces da secularização nos dias de hoje," Instituto Humanistas Unisinos, May 2, 2013, http://www.ihu.unisinos.br/171-noticias-2013/519716-charles-taylor-caracteristicas-einterfaces-da-secularizacao-nos-dias-de-hoje-.

${ }^{278}$ Taylor, Ethics of Authenticity, 36, 39, 46, 50, 82. 
combating social hierarchy, rejecting the conventional in favor of an original and selfresponsible way of life, and defending relativism. ${ }^{279}$

Conscious that the traditional theory of secularization incorrectly predicted the decline of faith and religious practice and the elimination of religion by science, Taylor set out to defend a set of new ideas about secularization. First, he explained that secularization allowed the evolution of a form of society in which it is conceived as usual for the state not to be aligned with any specific belief, whether religious or irreligious; in this case, a society in which metaphysical and religious options are free and equal, and there is freedom of expression. ${ }^{280}$

Another dimension of secularization, according to Taylor, is the changing situation of religious life in society, where religion is no longer seen only in linear form, associated with institutions that establish dogmas and how to express faith. Taylor pointed out that in modern times, a new form of religion has flourished, a more personal religious life, with intense and inner devotion, in which prayer, Bible reading, and meditation take place without the sacramental intervention of a church. People can easily leave churches or invent entirely new forms of religious life, giving birth to the so-called "Age of Mobilization" — a process of destabilization and recompositing that can be repeated many times over. ${ }^{281}$

The third dimension of secularization, in Taylor's view, is the religious version of the ethics of authenticity, already mentioned above, in which the individualization of faith prevails.

${ }^{279}$ Taylor, Ethics of Authenticity, 25-26, 65, 74.

${ }^{280}$ Taylor, A Secular Age, 238.

${ }^{281}$ According to Taylor, the Age of Mobilization "designates a process whereby people are persuaded, pushed, dragooned, or bullied into new forms of society, church, association. This generally means that they are induced through the actions of governments, church hierarchies, and/or other élites, not only to adopt new structures but also to some extent to alter their social imaginaries and sense of legitimacy." For him, the most dominant period of the Age of Mobilization took place between the years 1800 to 1960, culminating in the contemporary context of a plural, individualized religiosity without very definite boundaries and with a relativistic tone. Taylor, A Secular Age, 70, 75-76, 369, 437, 445, 462, 471, 506, 641. 
People define themselves as seekers, no longer conceiving of a society with one belief. They do not want anyone to say what they should do and think; they are seeking some spiritual and practical direction that satisfies them, but without allowing external mediation. Many of these people see themselves as spiritual but not religious because they associate religion with institutional dogma. ${ }^{282}$ This individualized authenticity and religiosity is characterized by relativism and subjectivism, since spirituality is seen as an inner feeling, perceived by each person in their relationship with their world and mind, without regulatory parameters. It is an experiential and syncretic spirituality marked by autonomous exploitation, as opposed to simple submission to authority or church. ${ }^{283}$ Therefore, the religious ethics of authenticity, which appears in the form of an individual, syncretic, experiential, and relativistic faith, is a preponderant element in Taylor's understanding of secularization.

\section{Talal Asad (1932- )}

A central element that characterizes secularization, in Asad's view, is the figure of the modern secular. Asad neither denied nor defended the secularization thesis, but took a different look at the phenomenon, placing more emphasis on the outcome than on the process of secularization. Asad drew attention to the concept of "the secular" as a product of this historical process that has played an important role in the context of modern society. ${ }^{284} \mathrm{He}$ insisted that both defenders and those who deny the secularization thesis must not forget that the concept of

\footnotetext{
282 Taylor, A Secular Age, 351, 508.

283 Taylor, A Secular Age, 508-9.

284 Talal Asad, Formations of the Secular: Christianity, Islam, Modernity (Stanford, CA: Stanford University Press, 2003), 1, 15.
} 
secularism predates the political doctrine of secularism, and was formed over time by a variety of concepts, practices, and sensibilities. ${ }^{285}$

Continuing to emphasize the outcome rather than the origin of the secularization process, Asad showed how secularization affected the concept of the essence of religion. He explained that in the premodern period, religion was seen as an integral part of the state, giving it coherence and legitimacy, and being an indispensable condition for its continuity. Thus, the social location of religion in this period was different from what came to be considered the essence of religion with the advent of the modern period. With the emergence of society as an organized secular body, religion was not only separated from its relationship with the state, but also enabled the state to oversee and facilitate the new task of religion: to be a transformative factor in the material and moral aspects of population, in a scenario of religious pluralism, of which the state itself became guardian and guarantor. ${ }^{286}$

From this perspective, Asad argued that the secular should not be thought of merely as a space in which real human life gradually emancipates itself from the controlling power of religion, as if religious ideas were "infective" of secular society. For him, the contemporary concept of the secular is part of a doctrine called secularism, which does not simply value the human or the mundane as opposed to the supernatural, or confine religious practice and belief to a private space, ensuring that they do not destabilize the politics and free-thinking of individuals. For him, secularism above all proposes a particular conception of the world, seeing it as a natural and social phenomenon that must be managed under the modernist ideals of freedom. ${ }^{287}$

\footnotetext{
${ }^{285}$ Asad, Formations of the Secular, 16.

286 Talal Asad, "Religion, Nation-State, Secularism," in Nation and Religion: Perspectives on Europe and Asia, ed. Peter van der Veer and Hartmut Lehmann (Princeton, NJ: Princeton University Press, 1999), 184-85.

${ }^{287}$ Asad, Formation of the Secular, 188, 191; Asad, “Religion, Nation-State, Secularism,” 185.
} 
For Asad, the ideological genealogy of secularism can be attributed to the Renaissance thesis of humanism, the Enlightenment concept of human nature, and the philosophy of history advocated by Hegel. Asad pointed out that Hegel described the modern period as the culmination of the movement of world history and an expression of truth and freedom. Hegel understood that the painful struggles of the Reformation, Enlightenment, and industrial revolution finally led to the objective and subjective conditions for a harmony based on the recognition of the secular as an embodiment of truth. ${ }^{288}$ However, Asad pointed out that in working on this theme of the historical development of secularism, he is not talking about causes, but about doctrinal elements that are part of the genealogy of secularism. ${ }^{289}$

While not in agreement with the intensity of the ideological reversal predicted by Hegel, Asad wrote that the historical process of secularization has enacted an ideological reversal in the meaning of the term "secular." First, the term "secularization" denoted the legal transition from monastic to secular life, characterizing the difference between someone who was part of the religious clergy and someone who was a layman. After the Reformation, the term came to denote the transfer of ecclesiastical royal properties into the hands of private persons, to circulate in the market. Finally, Asad wrote, in the discourse of modernity, the secular is portrayed as an autonomous being, representing the human being, now seen as the self-conscious creator of history, and the agent responsible for events, even those that are not conscious. From this

\footnotetext{
${ }^{288}$ Asad, Formation of the Secular, 192; Asad, "Religion, Nation-State, Secularism," 179, 185-86. See also G. W. F. Hegel, The Philosophy of History (Buffalo, NY: Prometheus Books, 1991), 422.

289 Talal Asad, "Responses," in Powers of Secular Modern: Talal Asad and His Interlocutors, ed. David Scott and Charles Hirschkind (Stanford, CA: Stanford University Press, 2006), 210.
} 
perspective, God's acts, or accidents, are admitted very narrowly, and chance is considered to be of weak consistency. ${ }^{290}$

Asad also drew attention to a kind of paradox between the secular and religion. Although the secular is seen as separate from religion, he claimed that many see it as a generator of religion; in the premodern period, secular life created a superstitious and oppressive religion. In the modern period, secularism produced enlightenment, and with it, religious freedom. Similarly, he stated that the concept of the secular is meaningless without the idea of religion, for it is the existence of the latter that gives meaning to the former. Thus, Asad suggested that the insistence on separating the religious from the secular is at least paradoxical. ${ }^{291}$

Asad pointed out that, according to modernism, religion consists of practices and representations that must be distinct and separate from politics, and the secular is the essential foundation for this to happen, incorporating a figure that represents the notions of holiness, spirituality, and solidarity. ${ }^{292}$ However, he argued that in the historical process, the secularization of religious concepts occurred, attributing a religious origin to the idea of nationalism, in which religious concepts are used for patriotic and domination purposes, without religious bias. ${ }^{293}$

Thus, Asad chose to put aside the defense or denial of secularization, preferring to analyze how religion can not only survive, but also be an instrument that promotes modern ideals through the secular contemporary world, without necessarily being associated with a religious institution. From this perspective, Asad argued that secularization is not essential to modernity.

\footnotetext{
${ }^{290}$ Asad, Formation of the Secular, 192; Asad, "Religion, Nation-State, Secularism," 186.

${ }^{291}$ Asad, Formation of the Secular, 193; Asad, "Religion, Nation-State, Secularism,” 186, 192.

292 Asad, "Religion, Nation-State, Secularism," 183-84.

${ }^{293}$ Asad, "Religion, Nation-State, Secularism,” 184.
} 
In other words, the idea that modernism necessarily requires religious emancipation does not, in his view, reflect the truth, because it is possible for religion to become an integral part and a promoter of modern policies related to economics, education, and public funding for scientific projects. $^{294}$

This kind of religion compatible with modernity plays a positive political role, entering the public sphere through a rational debate with opponents to persuade adherents rather than coerce them. It is a religion based on the assumption of liberal moral and political discourse compatible with modern thought. ${ }^{295}$ On the other hand, Asad did not define a specific type of religious experience that can be called modern religion or modern religiosity, preferring to bet that in a contradictory society, such as modern society, contradictory experiences must occupy spaces and processes, pointing to the coexistence of a plurality of beliefs and religious diversity. 296

Therefore, a prominent element that characterizes secularization, in Asad's view, is the figure of the secular, a product of broad historical development, including, but not limited to, the doctrine of secularization. From the above, it can be deduced that the contemporary secular for Asad incorporates a hybrid of modern and religious values at the same time. Contrary to the notion that in order to be modern, religion must necessarily be abandoned, Asad's secular defends the Enlightenment values of modernity, such as individual freedom of expression and choice, public funding for scientific projects, respect for differences, and others, without giving

\footnotetext{
Secularism," 179.

${ }^{295}$ Asad, "Religion, Nation-State, Secularism," 180.

296 Talal Asad, "Secularism, Hegemony, and Fullness," The Immanent Frame: Secularism, Religion, and the Public Sphere (blog), November 17, 2007, http://blogs.ssrc.org/tif/2007/11/17/secularism-hegemony-andfullness/.
}

${ }^{294}$ Asad, "Responses," 208-9; Asad, Formation of the Secular, 186-87; Asad, "Religion, Nation-State, 
up religious values as well. In short, seeing the state as an advocate and supporter of religious freedom, Asad's secular can practice religiosity while maintaining the Enlightenment principles espoused by modern thinking.

\section{Summary of Selected Independent Scholars}

According to the three selected independent scholars, the first element that characterizes secularization in the contemporary context is religious pluralism, and, as a consequence, relativization of the content of faith, as well as the individualization of belief. Second is the socalled ethics of authenticity, which in religious terms unfolds in the form of syncretic, experiential, relativistic, and individualized religiosity. Finally, the third is the contemporary secular, which upholds the modernist principles of the Enlightenment and at the same time maintains the religious experience while not necessarily linked to a religious institution.

\section{Summary}

Historically, the prediction of the weakening of religion has been fulfilled in three respects: First, institutional religion has shifted from the center to the edge of modern societies, while governments have become secular and support religious freedom. Second, the monopoly of the worldview has passed from religious institutions to science. Finally, the symbols and signs of religious institutions continue to lose relevance. ${ }^{297}$ Dobbelaere acknowledges that secularization is both a latent and a deliberate process. The latency of secularization is noticed when, as the various subsystems of society, such as economics, education, medicine, etc., become more specialized and professional, the influence of religion gradually declines. At the same time, deliberate policies of reducing the influence of religion in specific areas were

\footnotetext{
${ }^{297}$ Zepeda, "Secularização ou ressacralização," 130.
} 
established in many modern societies. ${ }^{298}$ However, the historical process has also shown that the prediction of the disappearance of religion was not fulfilled. Religion not only persisted, but in many cases grew and took a leading role in today's dynamic globalized societies.

In summary, according to the authors mentioned above, these are some of the main elements that characterize the theory of secularization: religious disenchantment; weakening of the public influence of religion; negative attitude toward religious institutions; transference of religion from the public sphere to the private sphere; multiplication of religious groups, enabling pluralism in a religious market environment and, with it, the consequent relativism of the content of faith; religious syncretism; the attitude of believing without belonging; the changing, permanent, and economic nature of religion; the contemporary secular that upholds both modern values and principles of faith; and the influence of technological advances, migration, and globalized and mass communication.

It is important to note that, although these elements that describe the theories of secularization have been evocated based on the assumptions of the Enlightenment movement, established in the modern period, these elements have achieved their most significant consolidation in postmodernity. ${ }^{299}$ Besides, possibly they are reflected in the experience of most of those who claim to be Nones, becoming impossible to study this group of people, without recognizing that to a large extent, they are a product of postmodernity. Nones are a global people group with great significance for Christian mission, being somewhat smaller than the largest world religions - Christianity and Islam. ${ }^{300}$ The next chapter will present a study of the Nones in 19.

${ }^{298}$ Karel Dobbelaere, Secularization: An Analysis at Three Levels (New York: P. I. E.-Peter Lang, 2002),

299 See Erickson, Truth or Consequences, 111-82.

${ }^{300}$ Pew Research Center, "Christians Remain World's Largest.” 
the United States and Brazil, from the perspective of secularization, based on the above elements that characterize secularization theories. 


\section{CHAPTER III}

\section{NONES IN BRAZIL AND THE UNITED STATES IN LIGHT OF THE SECULARIZATION THEORIES}

\section{Introduction}

This chapter analyzes the Nones in Brazil and the United States, based on the twelve main elements that characterize the theories of secularization, described in the previous chapter. To make the study less repetitive, the twelve elements are grouped into six categories, joining related topics:

1. Religious disenchantment

2. Weakening of the public influence of religion and, as a consequence, the transference of religion from the public sphere to the private sphere, and a negative attitude toward religious institutions

3. Religious pluralism in a market environment and the multiplication of religious groups, relativism of the content of faith, religious syncretism, and an attitude of believing without belonging

4. The changing and permanent nature of religion

5. The contemporary secular that upholds both modern values and principles of faith

6. The influence of technological advances and mass communication A summary of the categories will help identify the most relevant points of the discussion. A summary of the religious scenario and profile of the Nones in Brazilian and American cultures 
will be presented for context before the examination of the Nones and their relationship to the categories above.

\section{Summary of Religious Scenario and Profile of Nones in Brazil}

Contemporary studies have pointed out two macro-characteristics of Brazil that are significant for understanding religion in the country. The first macro-characteristic is religious plurality, especially in large urban centers, which is manifested through highly competitive, syncretic religious marketing without strict limits of belonging. ${ }^{301}$ The second macrocharacteristic of contemporary Brazilian religiosity pointed out by scholars is the transition of religious hegemony in the country from Catholicism to Protestantism, which should take place over the next two decades. If trends continue, the number of Catholics will fall sharply while the number of Protestants and Nones will grow, along with a small increase in non-Christian religions. While Catholics fell from 95.2 to 65 percent of the Brazilian population between 1940 and 2010, Protestants grew from 1.9 to 22.16 percent, and Nones went from 0.2 to 8.04 percent

\footnotetext{
${ }^{301}$ See Antônio Flávio Pierucci and Reginaldo Prandi, A realidade social das religiões no Brasil (São Paulo: Editora Hucitec, 1996); Alberto Antoniazzi, "As religiões no Brasil segundo o censo de 2000," REVER 2 (2003): 75-80; Rodrigues, "Religiosos sem igreja," 31-56; Alejandro Frigerio, "O paradigma da escolha racional: Mercado regulado e pluralismo religioso," Tempo Social 20, no. 2 (November 2008): 17-39; José Eustáquio Diniz Alves, Luiz Felipe Walter Barros, and Suzana Cavenaghi, "A dinâmica das filiações religiosas no Brasil entre 2000 e 2010: Diversificação e processo de mudança de hegemonia," REVER 12, no. 2 (July/December 2012): 145-74; Alessandro Bartz, "Trânsito religioso no Brasil: Mudanças e tendências contemporâneas," Congresso Internacional da Faculdades Est 1 (2012): 258-73, http://anais.est.edu.br/index.php/congresso/article/view/27; Marcelo Camurça, "O futuro das religiões no Brasil: O enfoque das ciências da religião," in Anais do IV Congresso da ANPTECRE: Associação Nacional de Pós-graduação e Pesquisa em Teologia e Ciências da Religião, ed. Gilbraz Aragão and Newton Cabral (São Paulo: ANPTECRE, 2013), 52-71; Elói Correa Santos, "Diversidade religiosa Brasileira e as quatro matrizes," ASSINTEC: Associação Inter-Religiosa de Educação, no. 38 (2016): 2-5; José Eustáquio Diniz Alves, "Uma projeção linear da transição religiosa no Brasil: 1991-2040," EcoDebate, January 11, 2017, https://www.ecodebate.com.br/2017/01/11/uma-projecao-linear-da-transicao-religiosa-no-brasil-1991-2040-artigode-jose-eustaquio-diniz-alves/.
} 
in the same period. Other religions jumped from 1.9 to 4.76 percent. ${ }^{302}$ In the city of Rio de Janeiro, the second largest in the country, only 46 percent of the population is Catholic. ${ }^{303}$

Table 1. Religions by Population Percentage in Brazil from 1940-2010

\begin{tabular}{|c|c|c|c|c|c|c|c|c|}
\hline Religion & 1940 & 1950 & 1960 & 1970 & 1980 & 1991 & 2000 & 2010 \\
\hline Catholic & 95.2 & 93.7 & 93.1 & 91.1 & 89.2 & 83.3 & 73.8 & 65 \\
\hline Protestants & 1.9 & 3.4 & 4.00 & 5.8 & 6.6 & 9.00 & 15.4 & 22.16 \\
\hline Nones & 0.2 & 0.5 & 0.5 & 0.8 & 1.6 & 4.8 & 7.3 & 8.04 \\
\hline Other & 1.9 & 2.4 & 2.4 & 2.3 & 2.5 & 2.9 & 3.5 & 4.76 \\
\hline Total & 100 & 100 & 100 & 100 & 100 & 100 & 100 & 100 \\
\hline
\end{tabular}

Source: IBGE Demographic Census.

The Datafolha institute has even higher numbers that point to the same trend of religious transition. According to the institute, from 1994 to 2016, Catholics fell from 75 to 50 percent of Brazil`s population, while Protestants grew from 14 to 29 percent, Nones from 5 to 14 percent, and other religions from 6 to 7 percent of the population. This means a loss of 1.14 percent a year for Catholics and a gain of 0.68 percent a year for Protestants. ${ }^{304}$

${ }^{302}$ Instituto Brasileiro de Geografia e Estatística, "Características gerais da população, religião."

${ }^{303}$ Pew Research Center, “Brazil`s Changing Religious Landscape,” July 18, 2013, https:/www.pewforum.org/2013/07/18/brazils-changing-religious-landscape/.

304 Datafolha, “A fé do Brasil," 2016, quoted in Diego Toledo, “Ateus 'saem do armário' religioso e reclamam de difícil aceitação no Brasil,” January 21, 2017, https://noticias.uol.com.br/cotidiano/ultimasnoticias/2017/01/21/ateus-saem-do-armario-religioso-e-reclamam-de-dificil-aceitacao-no-brasil.htm; Datafolha, "Perfil e opinião dos evangélicos no Brasil," December 7-8, 2016, http://www.pesquisas.org.br/wpcontent/uploads/2017/08/perfil_e_opiniao_dos_evangelicos_no_brasil.pdf. 
Table 2. Religions by Population Percentage in Brazil, August 1994 to December 2016-Nones Including Atheistic

\begin{tabular}{|c|c|c|c|c|c|}
\hline Religion & Aug/94 & Oct/01 & Oct/06 & Oct/10 & Dec/16 \\
\hline Catholic & 75 & 62 & 68 & 63 & 50 \\
\hline Protestants & 14 & 21 & 20 & 24 & 29 \\
\hline Nones & 5 & 7 & 5 & 6 & 14 \\
\hline Other & 6 & 10 & 7 & 7 & 7 \\
\hline Total & 100 & 100 & 100 & 100 & 100 \\
\hline
\end{tabular}

Source: Datafolha, http://datafolha.com.br.

For Alves, the correlation of forces between the two main Christian groups in the country is changing due to the activism of the Protestant branches, Catholic passivity, and the more significant interaction between the Protestant churches and politics. ${ }^{305}$ Evangelical growth is a broad and general phenomenon in the country, with higher intensity on the peripheries of metropolitan regions and in the agricultural frontier areas, as well as recent colonization in central and northern Brazil. ${ }^{306}$

Two particular results of religious pluralism and the transition from religious hegemony call the attention of those studying religion in Brazil. First, the percentage of Christians, taking into account Catholics and Protestants as a whole, decreased from 97 percent of the population in 1970 to 89.3 percent in 2000 and 86.8 percent in $2010,{ }^{307}$ giving way to non-Christian religions that already represent from 5 to 7 percent of the population (see Tables 1 and 2).

305 José Eustáquio Diniz Alves, "Transição religiosa - Católicos abaixo de 50\% até 2022 e abaixo do percentual de evangélicos até 2032,” EcoDebate, December 5, 2018, https://www.ecodebate.com.br/2018/12/05/transicao-religiosa-catolicos-abaixo-de-50-ate-2022-e-abaixo-dopercentual-de-evangelicos-ate-2032-artigo-de-jose-eustaquio-diniz-alves/.

306 José Eustáquio Diniz Alves, Suzana Marta Cavenaghi, Luiz Felipe Walter Barros, and Angelita A. de Carvalho, "Distribuição espacial da transição religiosa no Brasil," Tempo Social 29, no. 2 (August 2017 ): 237.

307 Alves et al., "Distribuição espacial da transição," 216. 
Second, pluralism and the transitional process have been seen as a lever for the country's Nones segment. ${ }^{308}$ In this context of pluralism, transition from religious hegemony, and growth of non-Christian religions, the appearance of those without religion on the Brazilian scene is possibly the final stage of the various religious experiences lived by people who decide to break with institutionalized religiosity. ${ }^{309}$ A survey carried out by the Vertex Institute in the metropolitan region of Belo Horizonte in 2012 found that when comparing childhood religion with current religion, the Nones grew the most, jumping from 1 to 500 percent (see Table 3). The research demonstrated not only the existence of an accelerated religious transit in the country, but also that the Nones represent the final stage of the religious experience of many, who, after going through various religious institutions, decide to manage their relationship with the supernatural without institutional assistance. ${ }^{310}$

${ }^{308}$ Alves et al., "Distribuição espacial da transição," 218.

${ }^{309}$ Pedro Ribeiro Oliveira, "A desafeição religiosa de jovens e adolescentes, entrevista especial com Pedro Ribeiro de Oliveira," Instituto Humanitas Unisinos, July 5, 2012, http://www.ihu.unisinos.br/entrevistas/511180desafeicao-religiosa-esse-conceito-seria-central-para-entendermos-os-sem-religiao-entrevista-especial-com-pedroribeiro-de-oliveira.

${ }^{310}$ Roberlei Panasiewicz, "Religião e Catolicismo em Belo Horizonte: Dados de pesquisa e leitura teológico-pastoral.” Horizonte 10, no. 28 (2012): 1260, 1267. 
Table 3. Childhood and Current Religion in \%

\begin{tabular}{|c|c|c|c|}
\hline Religion & $\begin{array}{c}\text { Religion in } \\
\text { Childhood }\end{array}$ & Current Religion & Growth \\
\hline Catholic & $84 \%$ & $60 \%$ & $-24 \%$ \\
\hline Pentecostal & $5 \%$ & $9 \%$ & $90 \%$ \\
\hline Neopentecostal & $4 \%$ & $13 \%$ & $210 \%$ \\
\hline Historical Protestant & $3 \%$ & $6 \%$ & $100 \%$ \\
\hline $\begin{array}{c}\text { Non-Christian } \\
\text { Religious Movements }\end{array}$ & $1 \%$ & $2 \%$ & $100 \%$ \\
\hline Spiritism & $1 \%$ & $3 \%$ & $200 \%$ \\
\hline Nones & $1 \%$ & $6 \%$ & $500 \%$ \\
\hline $\begin{array}{c}\text { Afro-Brazilian } \\
\text { Religions }\end{array}$ & $0 \%$ & $1 \%$ & \\
\hline
\end{tabular}

Source: Malco Camargos, ed., Transcrição da gravação dos grupos dos sem religião (Belo Horizonte: Vertex Pesquisa, 2012), 10.

According to the 2010 IBGE census data, the Nones were 8.04 percent of Brazilians at that time $(15,335,510)$, and according to the Datafolha Institute, in 2016, they were 14 percent of the country's population $(29,072,530.06)$. The average growth of the non-religious population has been continuously higher than that of the overall Brazilian population. ${ }^{311}$ They are the thirdlargest group in the religious field, behind only Catholics and Pentecostal evangelicals. They are located mainly in urban areas (89.5 percent), with a higher concentration in metropolitan regions, and along the Brazilian coast from north to south of the country. The southeast regions, with 9 percent; the Midwest, with 8.4 percent; the state of Rio de Janeiro, with 14.6 percent; the city of Salvador, capital of Bahia, with 17.28 percent; and the city of Chuí, in extreme southern Brazil, with an incredible 54.4 percent, show the most significant representation of Nones in the country. Brazilian Nones have the lowest average age among religious groups (26, predominantly between 15 and 35), compared to 28 for Protestant branches, 30 for Catholics,

${ }^{311}$ Vieira, “Os sem religião,” 606. 
and 37 for Spiritists. They are better represented among men (59.2 percent), against 40.8 percent for women. As for color and race, in absolute numbers, Nones are more represented among people of brown color $(7,217,638)$; by percentage, indigenous people with 14.5 percent and black people with 12 percent are the groups most represented among the Nones. The white population is the least represented among the Nones, at only 6.7 percent. ${ }^{312}$

The Nones in Brazil are the group that most often chooses consensual marriage unions (without documentary legalization) and are among the groups that most often choose civil marriage (see Figure 3). They are more represented at both ends of the educational spectrum: among those with up to elementary school education and those with master's and doctorate degrees. The great mass of the Nones in Brazil is in the most impoverished sections of the population, having to fight for survival on the peripheries of the largest cities. About 0.8 percent of them declare themselves agnostics and 4 percent atheists, while 95.2 percent say they believe in God or a cosmic force. That is, the majority of Brazilian Nones practice some spirituality, but are dissociated from institutional religion. ${ }^{313}$

\section{Summary of Religious Scenario and Profile of Nones in the United States}

The contemporary scenario of religiosity in the United States shows two relevant trends. The first includes a decrease among Christians (Catholics and Protestants), a small growth in non-Christian religions (Jews, Muslims, Buddhists, Hindus), and finally, substantial growth in

\footnotetext{
${ }^{312}$ Instituto Brasileiro de Geografia e Estatística, Censo demográfico 2010, 90-106; Datafolha, “A fé do Brasil.”

${ }^{313}$ Cesar Romero Jacob, Dora Rodrigues Hees, Philippe Waniez, and Violette Brustlein, Atlas da filiação religiosa e indicadores sociais no Brasil (Rio de Janeiro: Editora PUC-Rio, 2003), 115-16; Sandson Rotterdan, "A religião em xeque: Os sem religião no Brasil," Revista Senso, September 7, 2017, https://revistasenso.com.br/2017/09/07/religiao-em-xeque-os-sem-religiao-no-brasil/.
} 
Nones. ${ }^{314}$ Pew Research Center shows that in 2009, 78 percent of adult Americans were

Christians, decreasing to 71 percent in 2014 and 65 percent in 2018/2019. Non-Christians rose from 5 percent in 2009 to 6 percent in 2014 and reached 7 percent in 2018/2019. Nones were 16 percent in 2009, rising to 23 percent in 2014, and reaching 26 percent in 2018/2019. ${ }^{315}$

Table 4. Christians, Non-Christians, and Nones in the US in Three Moments in \%

\begin{tabular}{|c|c|c|c|}
\hline Year & Christians & Non-Christians & Nones \\
\hline 2009 & 78 & 5 & 16 \\
\hline 2014 & 71 & 6 & 23 \\
\hline $2018 / 2019$ & 65 & 7 & 26 \\
\hline
\end{tabular}

Source: Pew Research Center, 2019.

A decline in religious practice among Americans, or an increase in secularization in the country, is the second trend. This includes a drop in religious service participation; increased disinterest in religion, especially among new generations; and a drop in frequency of prayer. In 2009, 54 percent of adult Americans surveyed said they attended a religious service at least once a month, which fell to 50 percent in 2014, and to 45 percent in 2018/2019. The percentage of

\footnotetext{
${ }^{314}$ Gallup, "Religion,” 2019, https://news.gallup.com/poll/1690/religion.aspx?version=print.

${ }^{315}$ Pew Research Center, "In U.S., Decline of Christianity Continues at Rapid Pace: An Update on
} America 'S Changing Religious Landscape," October 17, 2019, https://www.pewforum.org/2019/10/17/in-u-sdecline-of-christianity-continues-at-rapid-pace/. According to the General Social Survey (GSS) of 2018, 23 percent of Americans are Nones. See Tom W. Smith, Michael Davern, Jeremy Freese, and Stephen Morgan, General Social Surveys, 1972-2018 (Chicago: NORC, 2018), http://gssdataexplorer.norc.org. 
those who said they attended a religious service a few times a year, or who never attended, went from 47 percent in 2009 to 50 percent in 2014 and 54 percent in 2018/2019. ${ }^{316}$

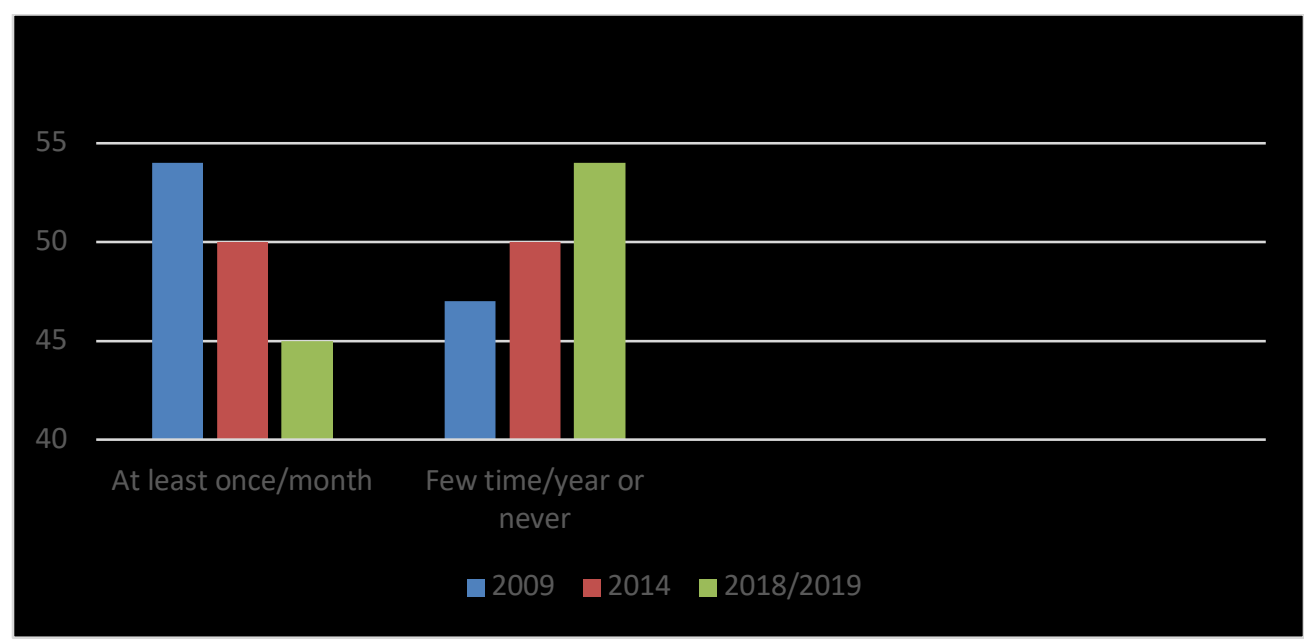

Figure 1. Frequency of attending religious services by Americans in \%. Source: Pew Research Center, 2019.

Regarding religiosity, in 2007, 56 percent of adult Americans surveyed said that religion was essential to them; in 2014, this dropped to 53 percent. Among the new generations, the problem is even more acute, as younger generations are less religious than older generations in America. While 67 percent of the Silent Generation (born 1928-1945) said that religion was very important to them, only 38 percent of millennials (born 1981-1996) said the same. In addition, many Americans showed a negative attitude towards religious institutions. Roughly half of them said religious institutions were too concerned with money and power (52\%), focused too much on rules $(51 \%)$, and were too involved with politics $(48 \%){ }^{317}$

\footnotetext{
316 Pew Research Center, "In U.S., Decline of Christianity."
}

317 See Pew Research Center, "5 Key Findings About Religiosity in the U.S.- - and How It's Changing," November 3, 2015, https://www.pewresearch.org/fact-tank/2015/11/03/5-key-findings-about-religiosity-in-the-u-sand-how-its-changing/; Pew Research Center, "More Americans Now Say They're Spiritual but Not Religious," 
Regarding the practice of prayer, in 2007, 75 percent of Americans surveyed said they prayed daily or weekly; in 2014, it dropped to 71 percent. ${ }^{318}$ Still, in a study on prayer frequency in 102 countries, the Pew Research Center found that the United States was the only country with both a high level of wealth ( $\$ 56,000$ per capita gross domestic product in 2015) and a high rate of daily prayer among the population (55 percent in 2014). ${ }^{319}$

The rise of the Nones in the United States is a phenomenon so substantial that it appears in most segments of society. Between 2007 and 2012, Nones were growing among men and women; white and black people; college graduates and those without a college degree; and people earning $\$ 75,000$ or more and those earning less than $\$ 30,000$ annually. They were also growing in all major regions of the country, and among Republican voters as well as among Democratic voters (though the increase was higher among Democrats). Nones are present in all generations of Americans, making up a quarter of the population. However, they are most common in younger generations. Among those who are 65 or older, only 9 percent declared themselves to be Nones, while 32 percent of those under 30 did. $^{320}$

September 6, 2017, https://www.pewresearch.org/fact-tank/2017/09/06/more-americans-now-say-theyre-spiritualbut-not-religious/.

318 Pew Research Center, "Religious Landscape Study: Frequency of Prayer," accessed May 11, 2020, https://www.pewforum.org/religious-landscape-study/frequency-of-prayer/.

${ }^{319}$ Pew Research Center, "With High Levels of Prayer, U.S. Is an Outlier Among Wealthy Nations," May 1, 2019, https://www.pewresearch.org/fact-tank/2019/05/01/with-high-levels-of-prayer-u-s-is-an-outlier-amongwealthy-nations/.

${ }^{320}$ See Pew Research Center, “A Closer Look at America's Rapidly Growing Religious Nones,” May 13, 2015, https://www.pewresearch.org/fact-tank/2015/05/13/a-closer-look-at-americas-rapidly-growing-religiousnones/; Pew Research Center, "Nones on the Rise"; White, Rise of the Nones. 


\section{Religious Affiliation by Age}

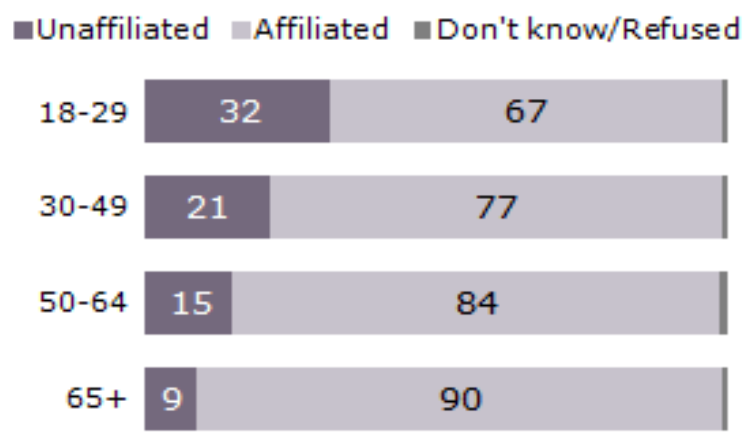

Source: Aggregated data from surveys conducted by the Pew Research Center for the People \& the Pres5, JanuaryJuly 2012.

PEW RESEARCH CENTER

Figure 2. Religious affiliation by age in the US.

As for religious identity, American Nones are quite diverse, with 29 percent atheists or agnostics, and 71 percent without particular religious affiliation. Although 68 percent of those surveyed declared they believed in God, just 30 percent were sure about this, and only 17 percent believed in God as described in the Bible. A little more than half of them, 53 percent, believed in a higher power or spiritual force, and 27 percent did not believe in God or in a higher power, which is very close to the number that identified as atheists/agnostics. The vast majority of Nones, 58 percent, seldom or never prayed, while just 21 percent reported praying daily, and 20 percent prayed weekly or monthly. Also, 18 percent of Nones declared themselves to be religious people, while 37 percent identified as spiritual but not religious, and 42 percent as neither spiritual nor religious. ${ }^{321}$

\footnotetext{
${ }^{321}$ Pew Research Center, "When Americans Say."
} 
Table 5. Summary of the Mean Religious Identity of American Nones in \%

\begin{tabular}{|c|c|}
\hline Identity & \% \\
\hline Atheistic/Agnostic & 29 \\
\hline Without particular religious affiliation & 71 \\
\hline Believe in God & 68 \\
\hline Believe in God with absolute certain & 30 \\
\hline Believe in God as described in Bible & 17 \\
\hline Believe in spiritual force & 53 \\
\hline Don't believe in God or spiritual force & 27 \\
\hline Pray & 41 \\
\hline Seldom or never pray & 58 \\
\hline Religious people & 18 \\
\hline Spiritual but not religious & 37 \\
\hline Neither spiritual nor religious & 42 \\
\hline
\end{tabular}

Source: Pew Research Center, April 25, 2018. 
Nones will be studied in light of the elements characterized in theories of secularization, aiming to understand the contemporary phenomenon of the Nones in both countries and provide insights into how to work with them.

\section{Category 1: Religious Disenchantment}

\section{Summary of the Topic}

Religious disenchantment is one of the elements that characterizes secularization in Max Weber`s view. For Weber, the spirit of capitalism, led by Enlightenment ideals of moral enrichment, produced technological advancement and scientific provision that resulted in the disenchantment of the world. This means that the mystical and magical elements related to faith in God would be replaced by a mechanistic and rational view of the world, guided by a perspective of causality. There would be a break with the unified moral, cognitive, and interpretative view of the world based on transcendental and spiritual values in the public domain. For Weber, these values would move from the public to the private sphere, making it challenging to maintain a religious ethos in the face of the pressure caused by rigid and efficient bureaucratic systems. ${ }^{322}$ As a follower of Weber`s ideas about religious disenchantment, Wilson explains that in a secular society, people no longer depend on supernatural concepts and moral presuppositions, but on instrumental and technical actions and voting decisions. In this case, instead of accepting their luck or waiting for God to guide their destiny and plans - a mystical and enchanted attitude - people rely on political and technical information for their decisions. ${ }^{323}$

\footnotetext{
${ }^{322}$ See Riesebrodt and Konieczny, "Sociology of Religion," 148-49; Weber, Essays in Sociology.

${ }^{323}$ Wilson, “Aspects of Secularization,” 266-67.
} 


\section{Relating the Topic to the Nones in \\ Brazil and the United States}

In both countries, the Nones are not homogeneous, and depending on the angle from which they are analyzed, there will be more or less connection with Weberian ideas of disenchantment. There are some indexes related to Brazilian Nones that demonstrate that this country`s population is the most connected with the process of religious disenchantment predicted by Weber and some of his disciples. Compared to the general population, civil marriage is 22 percent more common among Brazilian Nones, and consensual union without civil or religious support is 62 percent more common. Simultaneously, civil-religious marriage is 58 percent less common, and religious marriage alone is 52 percent less common. ${ }^{324}$ Thus, it can be said that the Nones are more inclined than the general population of Brazil to make their marital choices without concern for transcendental values and moral assumptions. Personal and secularized convenience guides their choices, supported by the state, rather than institutional religious orientation.

For Pierucci, the process of disenchantment of law in politically democratic countries left people autonomous regarding religion as a framework that directs life. This author applied Weberian disenchantment to legal matters, showing that Weber had in mind the growing autonomy of law in the West from the old framework, which was subjective and based on religious revelation. For him, Weber predicted the adoption of analytical techniques instead of magic formulas for the charismatic revelation of the law. ${ }^{325}$

\footnotetext{
324 Jacob et al., Atlas da filiação religiosa, 120.

325 Antônio Flávio Pierucci, "Secularização em Max Weber: Da contemporânea serventia de voltarmos a acessar aquele velho sentido," Revista Brasileira de Ciências Sociais 13, no. 37 (1998): 43-73.
} 
In colonial Brazil (1500-1822) and imperial Brazil (1822-1889), marriages were only religious, under the hegemony of Catholicism. Only in 1890, when Brazil became a republic, was civil marriage instituted, forcing the presence of state authority in recognition of unions. As of the 1934 constitution, the country began to recognize religious marriage with a civil aspectcelebrated by a religious figure, following the criteria and documentation required by the state, to have both civil and religious value. ${ }^{326}$ The 1988 constitution recognized stable unions-a stable union between a man and a woman, without civil documentation, would be legally converted into marriage after a minimum period of five years. In 2011, the Supreme Federal Court, in its systematic interpretation of the 1998 constitution, recognized same-sex unions as family entities in Brazil. ${ }^{327}$ In this perspective, the Brazilian Nones are the group that has most directly assimilated the effects of disenchantment, from the Weberian perspective, when applied to the aspect of conjugal union. More than other groups, they opt for marriage union without religious interference (see Figure 3).

${ }^{326}$ Adam Kovalik, "Efeito civil do casamento religioso no Brasil ontem e hoje," Âmbito Jurídico, May 31, 2007, https://ambitojuridico.com.br/edicoes/revista-41/efeito-civil-do-casamento-religioso-no-brasil-ontem-e-hoje/.

${ }^{327}$ James Muniz Marinho Junior and Maria Suely Cruz de Almeida, "O reconhecimento e dissolução de União Estável no Brasil e o meio processual cabível nas hipóteses de companheiros com ou sem filho menor de idade," Âmbito Jurídico, October 3, 2019, https://ambitojuridico.com.br/cadernos/direito-civil/o-reconhecimento-edissolucao-de-uniao-estavel-no-brasil-e-o-meio-processual-cabivel-nas-hipoteses-de-companheiros-com-ou-semfilho-menor-de-idade/. 


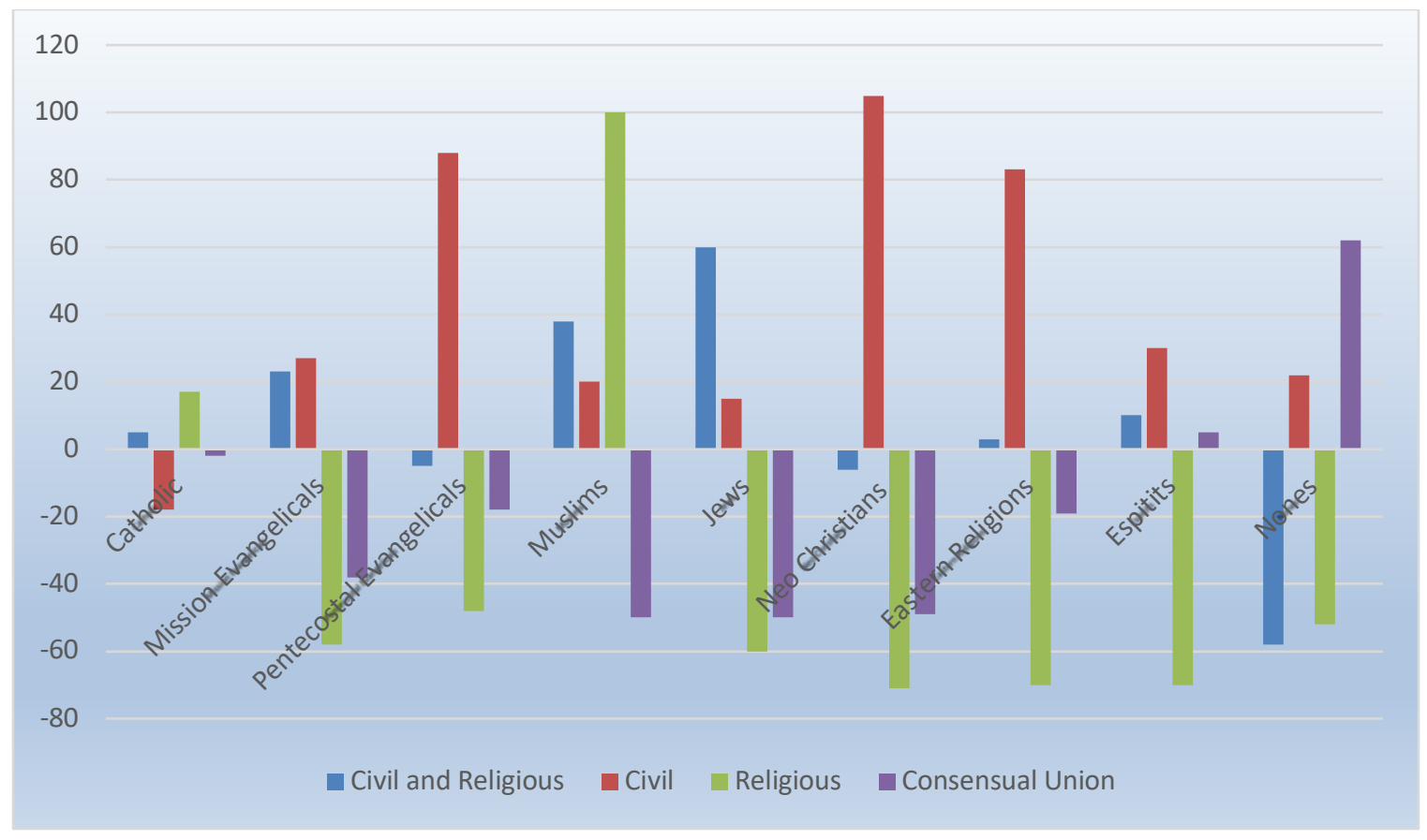

Figure 3. Nature of union in Brazil by religion compared with national average in \%. Source: IBGE Demographic Census, 2000.

This same view of marriage — based on independent choice and dissociated from values imposed by religion - can be seen among American Nones in at least two ways. First, they are the group in the country most likely to marry or live in romantic relationships with people of other faiths. According to a 2015 Pew Research Center survey, interfaith marriages among American groups were distributed as follows: Nones, 44 percent; Protestants, 41 percent; Jews, 35 percent; Muslims, 21 percent; Mormons, 18 percent; and Hindus, 9 percent. ${ }^{328}$ A second aspect is the rate of consensual union without legal ties among American Nones. Although it is not as common as in Brazil, Nones have the highest rate among American religious groups, at 11

${ }^{328}$ Pew Research Center, "Interfaith Marriage Is Common in U.S., Particularly Among the Recently Wed," June 2, 2015, https:/www.pewresearch.org/fact-tank/2015/06/02/interfaith-marriage/. 
percent. Catholics are 8 percent, Protestants 7 percent, Jews 6 percent, Muslims 8 percent, Mormons 7 percent, and 5 percent among Hindus. ${ }^{329}$

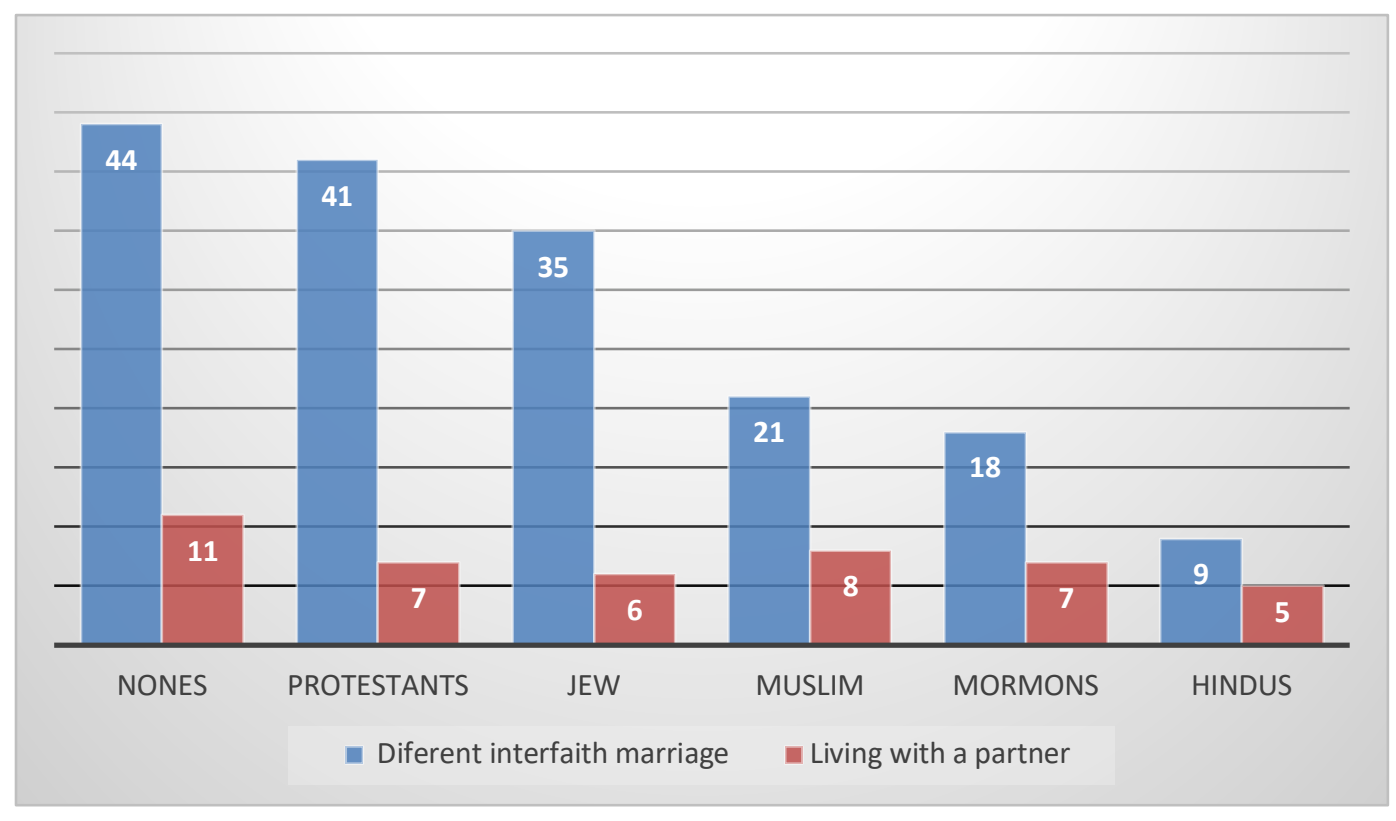

Figure 4. Interfaith marriage and living with a partner among religions in \%. Source: Pew Research Center, 2015.

Following this same reasoning, or considering Weberian disenchantment applied to the secularity of the state and society, Brazilian Nones are almost unanimous in criticizing the influence of religious institutions on issues that they consider to be the responsibility of the state, such as politics, abortion, and civil unions between people of the same sex, among others. ${ }^{330}$ This

${ }^{329}$ Pew Research Center, "Religious Landscape Study: Marital Status,” accessed March 26, 2020, https://www.pewforum.org/religious-landscape-study/marital-status/.

${ }^{330}$ See Denise S. Rodrigues, “Os sem religião e a crise do pertencimento institucional no Brasil: O caso Fluminense" (doctoral thesis, Universidade Federal do Rio de Janeiro, 2009); Tony Welliton da Silva Vilhena, "Religião e novos movimentos sociais: A experiência organizativa do comitê inter-religioso do Pará," in Anais do IV Congresso da ANPTECRE (Associação Nacional de Pós-graduação e Pesquisa em Teologia e Ciências da Religião), ed. Gilbraz Aragão and Newton Cabral (São Paulo: ANPTECRE, 2013); Ricardo Mariano, "Efeitos da secularizaçao do estado, do pluralismo e do estado religioso sobre as igrejas Pentecostais," Civitas—Revista de 
same less conservative trend is seen among American Nones, as 69 percent are in favor of homosexuality and 23 percent against; 59 percent are in favor of same-sex marriage and 32 percent against; 55 percent are in favor of abortion and 40 percent against. ${ }^{331}$ In both countries, the Nones reflect an affinity with Weberian ideas of disenchantment applied to legislation, placing the state in its secularity as responsible for ethical issues and social relationships.

On the other hand, if the application of Weberian disenchantment is related to the secularization of conscience, Brazilian Nones do not seem to reflect this aspect much. Less than 5 percent of them claimed to be agnostics or atheists. The vast majority, more than 95 percent, of Brazilian Nones said they believed in God or a cosmic force, and they also practiced some religiosity, dissociated from institutions. ${ }^{332}$ When analyzing American Nones, it is possible to reach the same conclusion about their relationship with spirituality: 68 percent of American Nones reported believing in God or a higher power, and 30 percent believed in God with absolute certainty, with 49 percent among men and 51 percent among women. Of these Nones who believed in God, 70 percent saw religion as necessary, and 28 percent saw religion as unimportant. $^{333}$

There is also a tendency to practice religiosity in the private sphere among American Nones. Of the Nones surveyed who believed in God, the majority did not attend religious

Ciencias Sociais, 2003, accessed December 5, 2017, https:/www.researchgate.net/publication/228657209_Efeitos_da_secularizac_ao_do_Estado_do_pluralismo_e_do_ mercado_religioso_sobre_as_igrejas_pentecostais.

${ }^{331}$ Pew Research Center, "Religious Landscape Study: Adults Who Believe in God with Absolute Certainty Who Are Unaffiliated (Religious Nones)," accessed March 30, 2020, https://www.pewforum.org/religious-landscape-study/religious-tradition/unaffiliated-religious-nones/belief-ingod/believe-in-god-absolutely-certain/.

332 Jacob et al., Atlas da filiação religiosa, 115-16; Rotterdan, “A religião em xeque.”

${ }^{333}$ Pew Research Center, "Religious Landscape Study: Adults Who Believe.” 
meetings, but 70 percent prayed daily or weekly, and only 21 percent said they never prayed. Also, 49 percent practiced meditation with some frequency, compared to 46 percent who never meditated; 72 percent said they felt a spiritual sense of peace often, while 17 percent never did; and 63 percent felt wonder about the universe quite often, while 28 percent never did.

Confirming their vocation for metaphysical and experiential religiosity without authoritative content, study of the Bible was practiced by 36 percent of Nones, compared to 56 percent who never read the Bible. In addition, 46 percent did not see the Bible as the Word of God, while 39 percent saw it as the Word of God, but only 26 percent said it should be taken literally. ${ }^{334}$

Table 6. Spirituality of US Nones Who Believe in God in \%

\begin{tabular}{|c|c|c|}
\hline Spiritual Activity & Yes & Never \\
\hline Pray daily / weekly & 70 & 21 \\
\hline Practice meditation & 49 & 46 \\
\hline $\begin{array}{c}\text { Have a spiritual feeling of peace often } \\
\text { frequency }\end{array}$ & 72 & 28 \\
\hline $\begin{array}{c}\text { Read the Bible } \\
\text { Fee the Bible as the Word of God/taken literally }\end{array}$ & $39 / 26$ & 46 \\
\hline
\end{tabular}

Source: Pew Research Center, Religious Landscape Study, 2014.

${ }^{334}$ Pew Research Center, "Religious Landscape Study: Adults Who Believe.” 
Based on the data above, about 68 percent of American Nones believe in God or a higher spiritual power, and engage in spiritual practices of an experiential and individual nature. Thus, it can be said that the religious disenchantment predicted by Weber and some of his disciples has not been fulfilled in the lives of most contemporary American Nones, if applied at the level of human consciousness. They are closer to the figure of the contemporary secular described by Asad, who maintains contemporary principles inherited from the modernist Enlightenment, such as freedom, individuality, and scientific advances, without giving up spiritual practice, based on institutional distance. ${ }^{335}$

However, if contemporary American Nones are viewed from another perspective, their relationship to the theme of world disenchantment changes. Data from 2017 show that about 47 percent of American Nones declared themselves to be spiritual or religious, while the majority, about 54 percent, said they were neither spiritual nor religious. ${ }^{336}$ Another study from 2012 by PRRI classified American Nones into three groups: Unattached Believers (23 percent), people who express religiosity but are disconnected from formal religious identity; Secular (39 percent), those who do not express religiosity; and Atheists and Agnostics (36 percent), those more critical of religion. ${ }^{337}$ In this study, adding Seculars to Atheists and Agnostics, $75 \%$ of Nones were disconnected from religiosity. According to the first survey, more than half were neither spiritual nor religious. In addition, 55 percent of Nones never or seldom attend religious services, and only 12 percent attend every week. Also, 73 percent of them never attend a prayer meeting, Bible

\footnotetext{
${ }^{335}$ Asad, "Religion, Nation-State, Secularism," 180.

${ }^{336}$ Pew Research Center, "More Americans Now Say."

${ }^{337}$ Daniel Cox, E. J. Dionne Jr., Juhem Navarro-Rivera, Robert P. Jones, and William A. Galston, "2012
} Pre-Election American Values Survey," PRRI, October 22, 2012, https://www.prri.org/research/american-valuessurvey-2012/. 
study, or religious event, and only 13 percent attend weekly. This non-participation in religious meetings demonstrates a general attitude of detachment from institutionalized religiosity. ${ }^{338}$ The trend of managing life from a secular perspective is another characteristic of American Nones, due to how they make their personal choices. Among Nones who believed in God, 71 percent said that right or wrong depends on the situation, and only 25 percent that there is a clear standard for what is right and wrong. When asked about the sources they consulted about right and wrong, only 19 percent said it was religion, compared to 12 percent who said philosophy, 8 percent science, and 71 percent common sense. ${ }^{339}$

Looking at it this way, disenchantment of personal conscience is confirmed in the experience of most American Nones. They seek to manage life and business independently of a cosmic influence, guided by technical principles, and based on free choice. In a 2011 survey by Baylor University, 66 percent of Nones saw conservative Christians as limiting people's freedom, and 34 percent said that science and technology made religion obsolete. ${ }^{340}$ However, there is evidence that even atheists do not experience absolute secularism. A PRRI survey showed that 27 percent of atheists in America were part of a congregation and had attended some religious service in the past months to give their children freedom of religious choice, due to spouse influence or community desire. ${ }^{341}$

\footnotetext{
${ }^{338}$ Pew Research Center, "Religious Landscape Study: Adults Who Believe."

${ }^{339}$ Pew Research Center, "Religious Landscape Study: Adults Who Believe.”

340 Baylor University, "Wave III of the Baylor Religion Survey Examines How Religion Affects Individuals` Outlook and Well-Being in Tumultuous Times,” September 20, 2011, https://www.baylor.edu/mediacommunications/news.php?action=story\&story=100503.

341 Amelia Thomson-DeVeaux, "Why Do Some Atheists Go to Church?", PRRI, December 9, 2011, https://www.prri.org/spotlight/why-do-some-atheists-go-to-church/.
} 


\section{Summary of Category 1}

The disenchantment predicted by Weber affects Nones in Brazil and the US, on both the level of legislation and the level of personal conscience. This conclusion is not absolute, as the group in both countries is very diverse, and a large portion continues to believe in God or a higher spiritual force and practice spirituality dissociated from institutional ties-something that was also predicted by Weber. However, it can be said that as a group, the Brazilian Nones are less affected by disenchantment in the context of personal awareness than the American group, which, according to the data analyzed, is more secularized.

\section{Category 2: Weakening of the Public Influence of Religion}

Summary of the Topic

The weakening of the public influence of religion and religious institutions, as well as the transfer of religion from the public to the private sphere as a consequence of secularism, are theses mainly defended by Weber and his disciples. For them, democracy, professional specialization, technology, experimental sciences, bureaucracy, and capitalism would affect the social influence of religion, as they would transfer some functions previously performed by the church to private agencies. Thus, the church`s authority and power to define what people should think, accept, and practice as moral principles would diminish. Weber and his disciples also argued that secularism would produce individual religiosity without an institutional aspect, also called invisible and subjective religion. They agreed that the secular model would not mean the 
eclipse of religion, but its transfer to the private sphere, generating a negative attitude toward institutionalized religion and bringing new forms of religious expression. ${ }^{342}$

\section{Relating the Topic to the Nones in \\ Brazil and the United States}

According to Berger, secularization is "the process by which sectors of society and culture are removed from the domination of religious institutions and symbols." 343 Berger points to objective secularization, or the separation between church and state, and the decline of religious content in the various social spheres. He also points to subjective secularization or secularization of conscience, meaning that people face the world and life without taking religious interpretations into account. ${ }^{344}$

In Brazil and the United States, people who identify themselves as Nones, or without religion, mostly claim to believe in God or in some spiritual entity, with atheists and agnostics being a minority among them. On the other hand, the percentages in the two countries are quite different: in the US, 29 percent of Nones claim to be atheists or agnostics, and 68 percent say they believe in God or a higher power, ${ }^{345}$ while in Brazil, atheists and agnostics represent only 4.8 percent of Nones, with 95.2 percent believing in God or a higher power. ${ }^{346}$ Despite this difference in percentages, the common factor for Nones who say they believe in God is that they break with established ways of experiencing spirituality, choosing to adhere to non-

\footnotetext{
342 See Weber, The Protestant Ethic, 105-12; Wilson, Religion in Secular Society, 14; Luckmann, The Invisible Religion, 26-30; Wallis, Elementary Forms, 57-60.

${ }^{343}$ Berger, The Sacred Canopy, 236.

${ }^{344}$ Berger, The Sacred Canopy, 226-39.

345 Pew Research Center, "Religious Nones Are Not Only."

${ }^{346}$ Instituto Brasileiro de Geografia e Estatística, Censo demográfico 2010, table 1.4.1.
} 
institutionalized forms of religious experience. In general, these people say they are Nones or without religion because they associate religiosity with institutions of which they have a profoundly negative image, and with which they do not want to associate. ${ }^{347}$

Qualitative research with two groups of Brazilian Nones, carried out by the Vertex Institute at the request of the Archdiocese of Belo Horizonte, found the following: 80 percent of them had passed through two or more religious traditions (Catholic, Protestant, or Spiritist) before declaring themselves Nones. Among the reasons they cited for their break with institutional religion were lack of time and unsatisfied personal search (personal reasons); parents' instability and religious disparity (family reasons); hypocrisy, lack of welcome, and transformation of the church into a market of faith (institutional reasons); and disbelief in the suitability of religions and incompatibility of views (religious reasons). For 80 percent of respondents, God existed and manifested independently of religions or churches. They said they sought God through prayer and outside the boundaries of institutionalized religions, which, according to them, deformed God. For them, the values that should guide human life could be cultivated outside of religion, and they highlighted love of one's neighbor as the primary value of life and superior to any religion. ${ }^{348}$

According to Vieira, the research attests that it is possible to form a non-institutionalized spirituality in contemporary Brazilian ideology, or, as they say, without religion. For the author, this break is institutional and religious in the sense of doctrines and beliefs. He also says that

\footnotetext{
${ }^{347}$ See Pew Research Center, “Why America`s 'Nones’ Don`t Identify.” See also Instituto Brasileiro de Geografia e Estatística, Censo demográfico 2010, table 1.4.1.

${ }^{348}$ Camargos, Transcrição da gravação dos grupos.
} 
contemporary Brazilian society, characterized by continuous and profound changes, favors the growth and dissemination of Nones in the country. ${ }^{349}$

Fernandes points out that there are four types of Nones from Brazil: those "of their religiosity," unbelievers, critics of religion, and atheists. Those "of their religiosity" are those who explore the Brazilian religious market, appropriating religious products from different Christian and non-Christian denominations, molding their religiosity according to their personal and syncretic taste, without any institutional commitment. ${ }^{350}$ A 2002 survey carried out by CERIS (Center for Religious Statistics and Social Research) on religious mobility in the central metropolitan regions of Brazil found that 41.4 percent of Nones reported having their own private religiosity, without institutional ties. ${ }^{351}$ In her research with a group of forty-eight Nones in the metropolitan region of Rio de Janeiro in 2007, Denise Rodrigues attested that some interviewees said they had no religion, but religiousness or spirituality. According to them, religion was a human invention to reconnect the human to the divine and to justify the search for the meaning of life, while spirituality was something intrinsic to each person, regardless of intermediaries. This led Rodrigues to conclude that "the 21 st century is marked more by a walk towards spirituality, than by religion, understood through some classic definitions." 352

In her survey, Rodrigues attested that of the 48 respondents, 30 expressed some criticism of religious institutions, 17 of which defined themselves as spiritual and 13 non-spiritual,

${ }^{349}$ Vieira, "Os sem religião."

${ }^{350}$ Silvia Regina Alves Fernandes, "Sem religião: a identidade pela falta?" in Mudança de religião no Brasil-desenvolvendo sentidos e motivações, ed. Silvia Regina Alves Fernandes (São Paulo: Palavra e Prece, 2006), 107.

${ }^{351}$ Mobilidade Religiosa no Brasil, “Testemunho: Região episcopal sé,” February 4, 2006, http://www.regiaose.org.br/testem/06_fev_04.pdf.

352 Rodrigues, "Religiosos sem igreja." 
covering all the age groups included in the survey. Among the most recurring reasons for not wanting a relationship with religious institutions were fanaticism, intolerance, hypocrisy, the use of power, the enrichment of religious leaders, and competition for members. ${ }^{353}$

Nones who are unbelievers, and those of self-religiosity, are disenchanted with religious institutions, but more affected by secularism. They may be agnostic or maintain a belief in God, but they discredit religious symbols and doctrines, often resulting from successive mobility experiences in which religious institutions were unable to satisfy their desires. ${ }^{354}$ Disbelief and disinterest can also result from a lack of motivation and a lower priority given to spiritual matters, typical of a secularized environment. ${ }^{355}$ Like the two previous groups, the Nones who are "critics of religion" also take an aversive position concerning religious institutions, but in a more forceful way. They may be the group most affected by secular influence and modernist rationalization, seeing religion as an illusion, ${ }^{356}$ or even as the opium of the people. ${ }^{357}$ Finally, the "atheist Nones," who represent 4 percent of the group in Brazil, are those who stand not only against religious institutions but also ideologically against belief in God or some cosmic entity. ${ }^{358}$

${ }^{353}$ Rodrigues, "Religiosos sem igreja," 51.

${ }^{354}$ Rafael Lopez Villasenor, “Crise institucional: os sem religião de religiosidade própria,” Revista Nures no. 17 (2011): 9-10, https://revistas.pucsp.br/index.php/nures/article/view/5517.

355 Stefano Martelli, A religião na sociedade pós-moderna (São Paulo: Paulinas, 1995), 271.

${ }^{356}$ An idea defended by the psychoanalyst Sigmund Freud. See Freud, The Future of an Illusion; Freud, Moses and Monotheism.

${ }^{357}$ Karl Marx defended the idea that "religion is the sigh of the oppressed creature, the heart of a heartless world, as it is the spirit of spiritless conditions. It is the opium of the people." See Karl Marx, "Contribution to the Critique of Hegel's Philosophy of Law: Introduction," in Karl Marx, Frederick Engels: Collected Works (New York: International Publishers, 1843-4/1975), 3:175.

358 Villasenor, “Crise institucional," 10. 
Therefore, it is clear that a common point among all Brazilian and American Nones is their critical view of religious institutions. Whether they maintain an individual and unrelated spirituality, or live without a relationship with the supernatural, they see religious institutions negatively or even as something to fight.

In her doctoral work on non-religious people in the Brazilian context, Rodrigues classified them into five types: first, the unruly, or those who drastically broke with their previous religion; second, the disconnected, or those who have gone through a milder distancing; third, the indifferent, who have no religious background and are not interested in religion; fourth, the seekers, those on a religious journey in an attempt to mitigate their spiritual needs; and fifth, the authentic, who establish a personal and independent system of religiosity. Rodrigues found evidence of a process of deinstitutionalization, detraditionalization, and the strengthening of reflexibility, which allows an attitude of disruption and challenge to consolidated systems. For her, all Brazilian Nones are without religion in the institutional sense, showing the crisis of institutional belonging in the country, but most of them express religiosity or unrelated spirituality of an individual nature, interpreting it as an intimate matter, separating the public from the private. ${ }^{359}$ Villasenor expresses a similar thought when stating that lack of official religion in Brazil does not necessarily mean disbelief in God or irreligiousness; it mainly means the abandonment of religious institutions, often accompanied by the creation of a religious syncretism guided by subjective and individual needs. ${ }^{360}$

Secularization in America has firmly reached the so-called mainline Protestant churches. The churches that make up the mainline group reached about 25 percent of the population at the

\footnotetext{
${ }^{359}$ Rodrigues, “Os sem religião.”

360 Villasenor, “Crise institucional," 3-4.
} 
end of the twentieth century, and today represent only 14.7 percent of Americans. They counted every American president as a member, except for the Catholic John Kennedy and Southern Baptists Jimmy Carter and Bill Clinton; produced the majority of US Supreme Court justices; and have been widely represented in Congress. However, they have increasingly lost prestige, influence, and theological-doctrinal definition among Americans. This group has been seen by representatives of evangelical Protestantism-Protestant churches that emphasize the need for new spiritual birth — as liberal and partly responsible for the moral and spiritual decline of American society, being, together with Catholics, the leading source of Nones. ${ }^{361}$

In their study of American Nones, ${ }^{362}$ based on various surveys, Baker and Smith of New York University argue that they reject public and institutionalized religion, but not necessarily the private and individualized practice of spirituality. According to them, excluding atheists, agnostics, and culturally religious people, at least once a month, 74 percent of the remaining group, classified by them as "non-affiliated believers," practice prayer; about half, 51 percent, feel a "deep sense of spiritual peace"; and 65 percent "feel a deep sense of wonder." Half of the non-affiliated believers said they believed in heaven, hell, Satan, and angels. On the other hand, the authors note that 59 percent of this group never attend religious services, and over 65 percent declare that "religion causes more conflict than peace." Nevertheless, when asked if religion was essential to their lives, only a third, 27 percent, said religion was not significant. The authors conclude that this pattern of behavior by non-affiliated believers tends to distinguish between public and private religion, rejecting the first, but not necessarily the second. In addition,

${ }^{361}$ Bryan F. Le Beau, A History of Religion in America: From the End of the Civil War to the Twenty-First Century (New York: Routledge, 2018), 222.

${ }^{362}$ Baker and Smith studied four groups of secular individuals: atheistic, agnostic, culturally religious, and unaffiliated believers. See Joseph O. Baker and Buster G. Smith, American Secular: Cultural Contours of Nonreligious Belief Systems (New York: New York University, 2015), 90. 
according to the authors, non-affiliated believers also demonstrate a high rejection of religious institutions. $^{363}$

An intriguing fact about Nones in America is that the overwhelming majority of them were brought up in a religious tradition. About three-quarters of adult Nones in the USA (74 percent) were raised as a member of a particular religion before shedding their religious identity in adulthood. ${ }^{364}$ For some reason, religious institutions are unable to retain them, especially when they reach young adulthood.

Studies show that "political reaction" is one reason why most Nones in the United States are young adults, especially from the millennial generation. They move away from religious institutions because these institutions advocate conservative policies. Two surveys published by the Pew Research Center in 2012 found that Nones were concentrated mainly among young adults and people with a liberal political ideology, defending issues such as same-sex marriage. The survey also found that 70 percent of Nones considered religious institutions to be very concerned with money and power, and 67 percent said these institutions were very involved in politics. In general, they were more likely than the religiously affiliated to say that churches should be kept away from political issues. ${ }^{365}$ The Pew Research Center survey proves what Hout and Fischer have stated since 2002. For them, "part of the increase in Nones can be seen as a

\footnotetext{
${ }^{363}$ Baker and Smith, American Secular, 89-92. See also Pew Research Center, "Why America`s 'Nones' Don`t Identify.”

${ }^{364}$ Pew Research Center, “Why America`s 'Nones’ Left Religion Behind,” October 24, 2016, http://www.pewresearch.org/fact-tank/2016/08/24/why-americas-nones-left-religion-behind/.

${ }^{365}$ See Pew Research Center, "More See 'Too Much’ Religious Talk by Politicians," March 23, 2012, https://www.pewforum.org/2012/03/21/more-see-too-much-religious-talk-by-politicians; Pew Research Center, "Little Voter Discomfort with Romney's Mormon Religion,” July 26, 2012, https://www.pewforum.org/2012/07/26/2012-romney-mormonism-obamas-religion/.
} 
symbolic statement against religious law." 366 Putnam and Campbell follow the same reasoning when pointing out that many young Americans started to see religion as "judgmental, homophobic, hypocritical and too political" in the face of the movement that occurred in the country between the 1970s and 1990s, in which conservative policies came to be defended as a campaign tool, with the support of religion, while gay rights and abortion became cultural flags. $^{367}$

Another factor in Americans` rejection of religious institutions is the postponement of marriage. Data show that among adults under thirty, married people are more likely to have a religious affiliation than singles. ${ }^{368}$ Wuthnow asserts that since the 1970 s, there has been a general decline in church attendance among Americans, attributing it to social and demographic trends including the postponement of marriage and parenting by an increasing number of young adults. ${ }^{369}$ However, data from the Pew Research Center show no growth in religious affiliation in the United States as people get older. The percentage of religious people in each generation tends to remain stable, with a small decline, as the generations age. However, the frequency of prayer and the degree of importance attributed to religion do increase with age — in this case, a

${ }^{366}$ Michael Hout and Claude S. Fischer, "Why More Americans Have No Religious Preference: Politics and Generations," American Sociological Review 67 (2002): 165.

${ }^{367}$ Robert D. Putnam and David E. Campbell, American Grace: How Religion Divides and Unites Us (New York: Simon \& Schuster, 2010), 120-21. See also John Corrigan and Winthrop S. Hudson, Religion in America, 9th ed. (New York: Routledge, 2018), 564.

\footnotetext{
${ }^{368}$ Pew Research Center, "Religious Landscape Study: Marital Status."

${ }^{369}$ Robert Wuthnow, After the Baby Boomers: How Twenty-and Thirty-Somethings Are Shaping the Future of American Religion (Princeton, NJ: Princeton University Press, 2007), 51-70.
} 
religiosity dissociated from institutional ties and tending towards the individualization of spirituality. 370

Some have seen a kind of broad social disengagement in American society in contemporary times. It is a type of general decline in "social capital" that manifests itself as individualism and less engagement in community activities. "Individualism has long been considered a core American value." ${ }^{371}$ Putnam describes this American individualism with the expression that gave the title to his book: "bowling alone," relating the growth of the Nones in America to the manifestation of a broad social disengagement." ${ }^{372}$ This association between the growth of the Nones and the individualism manifested in contemporary American society makes sense when it is noted that the people most likely to be involved in community activities and groups of volunteers from the most varied in society are considered "active" in religious communities. These people, who are more than just members, get involved in the regular life of the religious community and participate more than other Americans in different volunteer groups for the good of local society. ${ }^{373}$ Besides, Americans not affiliated with religious institutions are less likely than the general population to consider it important to belong to "a community of people who share their values and beliefs" (49 percent of the general population and 28 percent

\footnotetext{
${ }^{370}$ Pew Research Center, "Religion Among the Millennials: Introduction and Overview," February 17, 2010, https:/www.pewforum.org/2010/02/17/religion-among-the-millennials/.

${ }^{371}$ Pew Research Center, "Values and American Exceptionalism," October 4, 2007, https://www.pewresearch.org/global/2007/10/04/chapter-4-values-and-american-exceptionalism/.

372 Robert D. Putnam, Bowling Alone: The Collapse and Revival of American Community (New York: Simon \& Schuster, 2000).

${ }^{373}$ Pew Research Center, "The Civic and Community Engagement of Religiously Active Americans," December 23, 2011, https:/www.pewresearch.org/internet/2011/12/23/the-civic-and-community-engagement-ofreligiously-active-americans/.
} 
of the Nones see community participation as very important). ${ }^{374}$ Heehs sees the individualism of American society, as experienced more specifically by the Nones, as a reflection of a process that began with the arrival of the modern era. For Heehs, the modern era brought the principles of freedom and rationality, through which human individuality began to play a predominant role in traditional cultures, initiating a change of paradigms and the collapse of the Christian consensus. The contemporary popularity of an inner spirituality free from institutional restrictions, strongly present in the American and Brazilian Nones, is a result of this process. ${ }^{375}$

However, despite the growth of the Nones as a result of modern individualization, scholars have realized that they tend to value the social role of religion, in line with Durkheim's thesis on the value of religion in social terms. For Durkheim, society needs religion as an organizational tool for order and the manifestation of social values. ${ }^{376}$ In this perspective, the Nones have a certain sympathy for religious institutions that play a role in humanitarian service, promoting social welfare. In his research with Brazilian Nones, Rodrigues found that some of the interviewees who defined themselves as spiritual, and even some who said they had no spirituality, recognized that religion could help to discipline people and avoid social chaos, besides being a comfort, comfort, and assistance to explain what is inexplicable. ${ }^{377}$ White, who in the 1990s founded the Mecklenburg Community Church in Charlotte, North Carolina, mainly

\footnotetext{
374 Pew Research Center, “About the Pew Internet \& American Life Project,” June 27, 2007, https:/www.pewresearch.org/internet/2007/06/27/about-the-pew-internet-american-life-project/.

375 Peter Heehs, Spirituality without God: A Global History of Thought and Practice (New York: Bloomsbury Academic, 2019), 235.

376 Durkheim, Elementary Forms, 429, 432.

${ }^{377}$ Rodrigues, "Religiosos sem igreja," 51.
} 
aimed at reaching this group, argues that the Nones are especially sympathetic to initiatives related to service to others. ${ }^{378}$

Some sociologists associate economic development with secularization, concluding that the wealthiest societies are necessarily less religious. ${ }^{379}$ This means that religious beliefs and practices tend to be less intense in societies where there is greater existential security. In other words, the higher the financial security and the lesser the threat to health and well-being, the more secularized society tends to be, accompanied by the growth of the Nones. ${ }^{380}$ In more developed and wealthier countries, with a higher per capita income, people tend to be less religious, and in countries with lower per capita income, people tend to be more religious. ${ }^{381}$ However, the United States has been seen as an exception to this rule, as the country has both a high per capita income and high levels of religious commitment. ${ }^{382}$ On the other hand, Norris and Inglehart see the rise of the Nones in the United States as a sign that secularization is advancing in the country. For them, secularization is a cause of religious disaffiliation in American society. ${ }^{383}$

${ }^{378}$ White, Rise of the Nones, 143-48.

${ }^{379}$ See Jochen Hirschle, “'Secularization of Consciousness' or Alternative Opportunities? The Impact of Economic Growth on Religious Belief and Practice in 13 European Countries," Journal for the Scientific Study of Religion 52, no. 2 (2013): 410-24; Robert M. Wallace, "Progress, Secularization and Modernity: The LöwithBlumenberg Debate," New German Critique 22 (1981): 63-79.

${ }^{380}$ Pippa Norris and Ronald Inglehart, Sacred and Secular: Religion and Politics Worldwide (New York: Cambridge University Press, 2011), 216-17.

${ }^{381}$ Pew Research Center, "Values and American Exceptionalism."

382 Pew Research Center, "World Publics Welcome Global Trade—But Not Immigration," October 4, 2007, https://www.pewresearch.org/global/2007/10/04/world-publics-welcome-global-trade-but-not-immigration/.

${ }^{383}$ Norris and Inglehart, Sacred and Secular, 216. 


\section{Summary of Category 2}

Weakening of the public influence of religion and religious institutions, as well as transfer of religion from the public to the private sphere, can be seen in Brazilian and American cultures, and more clearly evidenced through the Nones of both countries. Both Brazilian and American Nones show an aversive attitude toward institutionalized religion, although, as Ribeiro said, most of them maintain the feeling of spirituality and are willing to welcome the transcendent dimension. ${ }^{384}$ In both countries, many Nones view religiosity as something private, guided by individual choices: what Steil calls analogical or metaphysical religiosity, of spiritual, subjective, ecological, therapeutic, or psychological orientation. ${ }^{385}$ It is a way of living faith by adopting sacred values present in various religions or philosophies of life, based on a subjective, personal syncretism, disconnected from institutional religiosity: a kind of invisible religion. ${ }^{386}$ Luiz calls this a deviation of the center of power from religious institutions to religious subjects. $^{387}$

As they live in different cultures, Brazilian and American Nones have an aversion to religious institutions for different reasons. Brazilians name their parents' religious inconsistency, lack of welcome, fanaticism, intolerance, hypocrisy, lack of suitability, abuse of power, the enrichment of religious leaders, and competition for members as main reasons for their

\footnotetext{
${ }^{384}$ Flávio Augusto Senra Ribeiro, "Os sem religião por eles mesmos," in A religião entre o espetáculo e a intimidade: VII Congresso Internacional em Ciências da Religião, ed. Alberto da Silva Moreira, Carolina Teles Lemos, Eduardo Gusmão de Quadros, and Rosângela da Silva Gomes (Goiânia, GO: PUC Goiás, 2014), 57.

${ }^{385}$ Carlos Alberto Steil, "Pluralismo, modernidade e tradição: Transformações do campo religioso," Ciências Sociais e Religião 3, no. 3 (2001): 120.

${ }^{386}$ Villasenor, "Crise institucional," 4, 6.

${ }^{387}$ Ronaldo R. Luiz, “A religiosidade dos sem religião,” Ciências Sociais e Religião 15, no. 19 (July/December 2013): 76.
} 
abandonment of institutional religion. On the American side, some of the main reasons include the deficiency of historical Protestantism and Catholicism in meeting the spiritual demands of their members, the individualism characteristic of American society, social and demographic trends such as the postponement of marriage and parenting by an increasing number of young adults, and liberal ideology, especially among younger generations.

On the other hand, some characteristics of contemporaneity transcend cultural barriers between the two countries and are shared between the two groups of Nones. They not only separate the Nones from religious institutions, but also encourage private religiosity among them. First is the principle of separation between church and state, attributing to the state the political function and the command of secular legislation, without links to religion. The Nones claim that churches are very involved in politics, in addition to being judgmental, homophobic, hypocritical, and concerned with money and power. Second, the contemporary trend of freedom and independence, including in the religious sphere, encourages more private religion based on personal choices. There is also a lack of priority given to spiritual matters, typical of a secularized environment, where people place work and other goals above religious commitment. However, evidence points out that the Nones attach a particular social value to religion, and tend to sympathize with religious institutions that promote people`s social well-being.

\section{Category 3: Religious Pluralism in a Market Environment}

Summary of the Topic

Religious pluralism is Berger`s main banner in his analysis of the contemporary effects of secularism. For him, modernism gave rise to secularism, which brought with it pluralism and relativism. Berger explains that pluralism generates cognitive contamination, or a kind of progressive numbness concerning the contradictory, in such a way that people start to accept 
what was previously not tolerated. Thus, absolute values gradually lose strength, resulting in relativism; applied to the religious world, this means the relativization of religious content. Also, he highlights, as a result of pluralism, the rise of religiosity based on a market context in which religion becomes subject to free and subjective choice according to the conscience of each person. "Opinion," "feelings," and "preferences" become the keywords, leading to flexibility in theology and alteration of religious content. ${ }^{388}$ As part of this same reasoning for the multiplication of religious experiences, Wilson points to the advent of ecumenism-a process in which religious institutions merge through the acculturation of religious commitments, producing religious syncretism. ${ }^{389}$ Grace Davie noted that, especially among young people and less educated people, secularism has not resulted in the disappearance of religion and values, but in the decline of religious institutions, leading her to coin the expression "believing without belonging." According to Davie, the church's association with power and dominance, access to religious content through the mass media, the many entertainment options in the contemporary world, and "vicarious religion," or "the notion of religion performed by an active minority but on behalf of a much larger number," are among the main reasons people report for distancing themselves from religious institutions today. ${ }^{390}$ Starks and Iannaccone theorize that belief without institutional belonging, in a religious market context, leads to what they call "religious mobilization," a great process of displacing people among various religious options. According to them, the more pluralistic and competitive the religious economy, the higher the involvement

\footnotetext{
${ }^{388}$ See Berger, Questions of Faith, 251-52, 268, 271-73; Berger and Zijderveld, In Praise of Doubt, 14748; Berger, Many Altars, 2-3; Berger, The Sacred Canopy, 271-80.

389 Wilson, Religion in Secular Society, 1-2.

390 See Davie, "Believing without Belonging," 462; Davie, Sociology of Religion, 44, 98, 99, 140; Davie, Religion in Modern Europe, 68, 69; Davie, Religion in Britain Since 1945, 94, 112, 113.
} 
of people, and at the same time, the lower the institutional loyalty. ${ }^{391}$ Taylor calls this contemporary religious movement a "post-Durkheimian" period, characterized by the ethics of authenticity and individual, syncretic, experiential, and relativistic faith, in which people define themselves as "seekers" or "spiritual but not religious," maintaining spiritual values without connection with religious institutions. ${ }^{392}$

\section{Relating the Topic to the Nones in Brazil and the United States}

Scholars have used the expression contemporary religiosity to refer to the religious context in force in Brazil and the United States today. The expression refers to a pluralist environment marked by elements that characterize the theory of secularization, which were foreseen in the modern period but reached their stage of maturity in postmodernism, such as the emphasis on spirituality without institutional links, relativism, and religious marketing, among others. ${ }^{393}$ In general, religious pluralism refers to the number of "religious firms" active in a society's religious economy. ${ }^{394}$ This work considers a religious firm to be a distinct religious group, including Christian and non-Christian religions. On the other hand, the "religious economy" refers to all religious activities practiced in a society, especially in a religious market

391 Stark, "Secularization, RIP," 249-73; Iannaccone, "Introduction to the Economics of Religion," 1498; Laurence R. Iannaccone, Roger Finke, and Rodney Stark, "Deregulating Religion: The Economics of Church and State," Economic Inquiry 35 (April 1997): 351-52.

392 See Taylor, A Secular Age, 512-31, 538; Taylor, Ethics of Authenticity, 25, 26, 36, 39, 46, 50, 65, 74, 82; Taylor, "Características e interfaces."

${ }^{393}$ Wade Clark Roof, ed., Contemporary American Religion, vol. 1 (New York: Macmillan Reference USA, 2000); Roberlei Panasiewicz, Cláudio de Oliveira Ribeiro, and Gilbraz de Souza Aragão, "Espiritualidades contemporâneas, pluralidade religiosa e diálogo," in Anais do IV Congresso da ANPTECRE (Associação Nacional de Pós-graduação e Pesquisa em Teologia e Ciências da Religião), ed. Gilbraz Aragão and Newton Cabral (São Paulo: ANPTECRE, 2013).

${ }^{394}$ Rodney Stark and Roger Finke, Acts of Faith: Explaining the Human Side of Religion (Berkeley, CA: University of California Press, 2000), 198. 
context, in which people are exposed to a wide variety of religious options, as a rule, divided by a market system. ${ }^{395}$

\section{The Foundations of Religious Pluralism}

Among the leading causes for religious pluralism in both societies, linked to the process of secularization, are the conception of a secular state with the separation of church and state, an environment of religious freedom, the installation of a religious market, the multiplication of new cults and sects within Christianity, the growth of non-Christian religions, subjective spirituality, and dissociation from institutional belonging.

Brazilian religious pluralism, with its syncretic characteristics, was established based on different matrixes, mostly associated with colonization and immigration. ${ }^{396}$ Catholicism, brought by the Portuguese in $1500,{ }^{397}$ was practiced along with the indigenous beliefs of the local inhabitants. The rituals of Candomblé and other religious forms of the African matrix came with the slaves between 1549 and 1850 . The mix was enhanced by the Protestantism that arrived in colonial Brazil between the sixteenth and seventeenth centuries, and was strengthened by Pentecostalism in the twentieth century, and most recently Neopentecostalism. The Eastern religious matrix also came to Brazil with immigrants in the early twentieth century, especially the Japanese. Judaism, Islam, and exoteric religions have also shown significant growth in

\footnotetext{
${ }^{395}$ Stark and Finke, Acts of Faith, 193.

${ }^{396}$ René Deccol, "Imigração internacional e mudança religiosa no Brasil," USSP, 2001, http://www.abep.nepo.unicamp.br/iussp2001/cd/GT_Migr_Deccol_Text.pdf.

397 The first Catholic mass in Brazil was celebrated by Frei Henrique de Coimbra, in Porto Seguro, BA, on April 26, 1500, four days after the discovery of the country by Pedro Alvares Cabral. Cabral's vessel carried Jesuit priests, who came with the official mission to catechize the new Portuguese colony. See Artur Cesar Isaía, "A hierarquia Católica Brasileira e o passado Português," in Portugal-Brasil no século XX: Sociedade, cultura e ideologia, ed. Christiane Marques Szesz et al. (Bauru: Edusc, 2003), 250.
} 
Brazil. This wide diversity of religious practices is the basis for a religious syncretism quite characteristic of the local population. ${ }^{398}$

Another factor that has propitiated religious pluralism in Brazil, according to Prandi, is secularization: first, the already consolidated secularization of the state, and second, the secularization of culture, still in progress, which has allowed Brazilians to choose religions different from the one in which they were born. ${ }^{399}$ In colonial Brazil (1500-1822) and imperial Brazil (1822-1889), Catholicism was the official religion. Article 5 of the 1824 constitution allowed the practice of other religions, but only privately and without proselytism. ${ }^{400}$ Brazil became a secular state with the proclamation of the republic in 1889 , making the separation of church and state official, ${ }^{401}$ and gaining a system of social protection and citizenship rights defined in the 1988 constitution, which favored the plurality of religious options. ${ }^{402}$ An internal multiplicity in the Christian field followed, with the installation of diverse new groups of

\footnotetext{
${ }^{398}$ See Regina Novaes,"'Os jovens sem religião: Ventos secularizastes, espirito de época e novos sincretismos. Notas preliminares," Scielo Analytics—Estudos Avançados 18, no. 52 (2004): 326; Santos, "Diversidade religiosa Brasileira," 2-5; Wagner Kuhn, "Understanding Religious Syncretism in Brazil: Cases in Dual Allegiance with Implications for Adventist Mission," Revista Hermeneutica 7 (2007), http://www.seeradventista.com.br/ojs/index.php/hermeneutica/article/view/205/198; Boris Fausto, História do Brasil (São Paulo: Edusp, 1995), 20-21; Luiz, "A religiosidade dos sem religião," 74; Basílio Röwer, Páginas de história Franciscana no Brasil (Petrópolis RJ: Editora Vozes, 1941); Jorge Amado, Jubiabá, 40th ed. (Rio de Janeiro: Record, 1981); Antônio Narcélio Machado Portela, "Os primeiros Protestantes no Brasil colonial: Séculos XVI a XVII,” Monografias Brasil Escola: Historia, 2018, accessed March 17, 2018, https://monografias.brasilescola.uol.com.br/historia/os-primeiros-protestantes-no-brasil-colonial-seculos-xvixvii.htm; Olívia Maria Gomes da Cunha, "Fazendo a 'coisa certa': Reggae, rastas e Pentecostais em Salvador," 1991, accessed March 17, 2018, http://www.anpocs.org.br/portal/publicacoes/rbcs_00_23/rbcs23_09.htm.

${ }^{399}$ R. Prandi, “Converter indivíduos, mudar culturas,” Tempo Social 2, no. 20 (2008): 170.

400 "The apostolic Roman Catholic religion shall continue to be the religion of the Empire. All other religions shall be permitted with their domestic or private worship in buildings destined therefor, but without any exterior form of a temple." See "Constitution of the Empire of Brazil," accessed June 18, 2020, https://en.wikisource.org/wiki/Constitution_of_the_Empire_of_Brazil.

401 The decree $\mathrm{n}^{\mathrm{o}} 1$ issued by the Provisional Government of Mal Deodoro da Fonseca and, later, Decree 119-A of January 7, 1890, guaranteed the laity of the Brazilian state.

402 Alves et al., "Distribuição espacial da transição," 223.
} 
Pentecostal and Neopentecostal evangelicals, the charismatic renewal of Catholicism, and, more recently, the so-called undetermined evangelicals. Brazil has a growing religious plurality in general, with many non-Christian options, and even experiences of spirituality without institutional bias. ${ }^{403}$

On the North American side, religion and religious freedom have played a fundamental role since the beginning of the nation. Catholicism was brought to the United States by the Spaniards in the 1500s, and for three hundred years, Spanish and Latin American missionaries and settlers strengthened the church`s presence, especially in Florida, the Southwest, and California. In the 1600s, settlers, mainly from England, brought Protestantism to the country, having left their countries of origin due to religious persecution by European Catholicism. The denominations that formed this first Protestant nucleus in the country are known today as mainline or historical Protestant churches: Baptists, Methodists, Lutherans, Presbyterians, Episcopalians, and the United Church of Christ. ${ }^{404}$ At first, some denominations tried to force their views and beliefs on others, but the idea of separation between church and state was advocated by the nation's founding colonists, including John Clarke, Roger Williams, William Penn, and founding fathers like James Madison, Thomas Jefferson, and Thomas Paine. ${ }^{405}$

The US Constitution adopted in 1798, in its first amendment, prohibited the creation of a religious state, establishing the separation between church and state, and guaranteeing religious

\footnotetext{
${ }^{403}$ Faustino Teixeira and Renata Menezes, eds., Religiões em movimento: O censo de 2010 (Petrópolis, RJ: Editora Vozes, 2013), 25.

${ }^{404}$ Maryanne Kearny Datesman, Joann Crandall, and Edward N. Kearny, American Ways: An Introduction to American Culture (White Plains, NY: Pearson Education, 2014), 54-55.

${ }^{405}$ Thomas Jefferson, “Jefferson`s Letter to the Danbury Baptists," Library of Congress, January 1, 1802, accessed May 18, 2020, https://www.loc.gov/loc/lcib/9806/danpre.html; Library of Congress, "The State Becomes the Church: Jefferson and Madison," June 4, 1998, https://loc.gov/exhibits/religion/rel06-2.html; Locke, Two Treatises; Paine, Age of Reason, 44-49, 138-42.
} 
freedom in the country. The concepts of individual and religious freedom, as well as the diverse ethnic background of the population, have been seen as fundamental factors in the religious pluralism existing in the United States today. The immigration process that brought to the country Africans, Jews, Muslims, Indians, Asians from different countries, people of Hispanic origin, and others, has contributed to establishing a plural religiosity, including the presence of many non-Christian religions. ${ }^{406}$

In this pluralistic scenario, where Christians, including Protestants and Catholics, are declining, non-Christian religions are experiencing some growth, and Nones and nondenominational evangelicals are experiencing significant growth (see Table 4), some contemporary trends in American society should be noted. First, most Americans believe that many paths lead to God and that their religion is not the only valid faith. In other words, the traditional lines of separation between denominations and religions have been weakened. People move between denominations or seek to enjoy religious services without belonging, using the criterion of free choice, regardless of the origin of the religious products. This is the case with the Nones; especially among younger generations, they marry people of other faiths and exploit the religious market, benefiting from a spiritualistic religiosity without links to institutions. ${ }^{407}$

The Nones of both countries see positive and negative aspects of religious pluralism. Among the positive factors are freedom of religious choice, the possibility of believing and benefiting from widely available religious products without belonging, and the eclectic spirit of considering all religious options valid. On the other hand, competition for church members, the

\footnotetext{
${ }^{406}$ Datesman, Crandall, and Kearny, American Ways, 56.

${ }^{407}$ Datesman, Crandall, and Kearny, American Ways, 62.
} 
enrichment of religious leaders, and the political and commercial nature of faith are among the negative aspects of religion in the view of the Nones. ${ }^{408}$

\section{Effects of Religious Pluralism}

There is no unanimity among sociologists of religion regarding the effects of religious pluralism. However, there are three most frequently held positions. First, the "religious economy model" argues that the higher the level of religious pluralism, the greater the religious competition for supporters, and consequently, the higher the level of individual religiosity. For supporters of this model, religious competition contributes to the spiritual growth of people in society, as it allows for more significant interfaith contact. According to them, people individually make their religious choices, and the more choice available, the greater the religious commitment. ${ }^{409}$

Second, the "modernization model," advocated by Peter Berger, argues that as religious pluralism increases due to modernist principles, religion`s "taken-for-grantedness" is lost by a process he calls “cognitive contamination.” In Berger's conception, as individuals come into contact with different religious experiences, they become aware that their particular faith cannot be taken as a guarantee, and consequently, their level of trust in and commitment to a singular faith decreases. That is, the more interaction among religions, the less religious dogmatism at the individual level. However, Berger argues that religious pluralism would produce a religiosity typical of modernism, which he calls inclusive spirituality, guided by particular preference,

\footnotetext{
${ }^{408}$ See Rodrigues, "Religiosos sem igreja”; Pew Research Center, "More See 'Too Much’ Religious Talk"; Pew Research Center, "Little Voter Discomfort."

${ }^{409}$ See Roger Finke and Rodney Stark, The Churching of America 1776-2005: Winners and Losers in Our Religious Economy (New Brunswick, NJ: Rutgers University Press, 2005); Iannaccone, Finke, and Stark, "Deregulating Religion"; Stark and Finke, Acts of Faith.
} 
according to the individual`s need, will, and interest. Therefore, for Berger, pluralism decreases religious, dogmatic, and institutional commitment, and increases individualized spirituality based on personal preferences. ${ }^{410}$

Finally, the "non-effect model" argues that interfaith contact does not interfere with individual religiosity. For this group, modernism reduces the level of existential insecurity, fueling the search for religion. In this case, since religious pluralism is a product of modernity, and since modernity diminishes religious interest, pluralism has no effect on religiosity at the individual level. They argue that religiosity is determined by other factors and relationships, separate from pluralism. ${ }^{411}$

Although the purpose of this study is not to prove which of the theories about the effects of pluralism is the most correct, they will serve as a parameter to verify some of the effects of religious pluralism in Brazilian and American societies, especially for the Nones, or people who declare themselves without religion. In this sense, and due to limitations of space, the analysis will be based on two elements related to religious pluralism in both cultures: the establishment of market religiosity and the growing emphasis on religion`s spiritualization.

\section{Market Religiosity}

Market religiosity is the scenario where churches and cults act as religious companies, offering religious products, intending to meet the preferences of spiritual customers. In turn, people choose the religious products that meet their demands from day to day and explore them without concern for their origin or commitment to a particular church. As Mariz and Machado

\footnotetext{
${ }^{410}$ Berger and Zijderveld, In Praise of Doubt, 30-32, 69, 156; Berger, The Sacred Canopy.

${ }^{411}$ See Norris and Inglehart, Sacred and Secular.
} 
said, the religious market is a trend of modernity, marked by the primacy of the individual and free choice through conscience with the consequent fixation of the principle of identity. ${ }^{412}$ Market religiosity creates a high level of competitiveness between religions in the search for adherents, not only giving religious consumers more opportunity of choice but also basing that choice on the taste of customers, not the biblical-theological content.

In Brazil, the religious market is highly competitive and syncretic, without strict limits of belonging, which has sharply increased the growth of religious forms, raising religious plurality in the country from 66.6 percent in 1991 to 76.2 percent in 2010 , based on the number of religious options. ${ }^{413}$ In this context, Catholics continue to be the majority group but have lost space in absolute and relative terms. Protestants (including mainline Protestants, traditional evangelicals, Pentecostals, Neopentecostals, and unidentified evangelicals) are the fastestgrowing group. Non-Christian denominations have a smaller rate of growth, and the Nones are outstripping them. ${ }^{414}$

The saturation of religious offerings, religious syncretism, and competition for believers among denominations have also been identified as factors that lead Brazilians to abandon their institutional commitment, choosing to practice faith independently of religious affiliation. ${ }^{415} \mathrm{~A}$

\footnotetext{
412 Cecilia Mariz and Maria das Dores Campos Machado, "Mudanças recentes no campo religioso Brasileiro," Antropolítica 5 (1998): 21-39. See also Marcelo C. Neri, ed., A economia das religiões: Mudanças recentes (Rio de Janeiro: FGV/IBRE, CPS, 2007).

413 José Eustáquio Diniz Alves, “A transição religiosa na América Latina e no Brasil,” EcoDebate, May 31, 2017, https://www.ecodebate.com.br/2017/05/31/transicao-religiosa-na-america-latina-e-no-brasil-artigo-de-joseeustaquio-diniz-alves/.

414 See Tables 1 and 2; see also Alves, "A transição religiosa.”

415 Jones Godinho, “A individualização da espiritualidade como fruto da desfiliação religiosa: Os sem religião," accessed November 15, 2018, https://www.academia.edu/28152352/A_individualização_da_espiritualidade_como_fruto_da_desfiliação_religiosa_ os_sem_religião; Novaes, "Os jovens sem religião."
} 
common observation is that these people have gone through different religions but not found satisfaction in them, and thus opted for an autonomous relationship with God. ${ }^{416}$ There is a relationship between the deconversion of Catholics and the conversion of evangelicals, and, at the same time, between the deconversion of Catholics and evangelicals and the growth of those who declare themselves to be Nones in Brazil. ${ }^{417}$

According to the projections of the Pew Research Center, the Nones are the group that will grow the most in proportional terms between 2010 and 2050, not only in Brazil but throughout Latin America and the Caribbean. On the continent, the growth projection for Nones is 44 percent, followed by adherents of folk religions at 43 percent, and Christians (Catholics and Protestants) at 25 percent (see complete data in Table 7). The main reasons the center cites for the projected growth of the Nones are their relatively high average fertility rate of 2.3 percentslightly above Christians, with a fertility rate of 2.2 percent, and Hindus, with 1.6 percent — and the high level of religious switching in the region. Religious pluralism on the continent facilitates religious switching, and the Nones have an advantage in this process, according to the Pew Research Center, because they have the lowest average age among the main religious groups, 26, which makes them more susceptible to sociocultural changes. Also, most of the Nones are men, a desirable feature for the migration of male people from other religions to the group. ${ }^{418}$

\footnotetext{
${ }^{416}$ Luiz, "A religiosidade dos sem religião."

417 Villasenor, "Crise institucional”; Rotterdan, “A religião em xeque.”

${ }^{418}$ Pew Research Center, "The Future of World Religions: Population Growth Projections, 2010-2050: Latin America and the Caribbean," April 2, 2015, https:/www.pewforum.org/2015/04/02/latin-america-and-thecaribbean/; Pew Research Center, "Religion in Latin America: Widespread Change in a Historically Catholic Region,” November 1, 2014, https://www.pewforum.org/2014/11/13/religion-in-latin-america/; Ministério da Saúde, Centro Brasileiro de Análises e Planejamento, "Pesquisa sobre o comportamento sexual da população Brasileira e percepções do HIV/AIDS," March 28, 2006, http://www.aids.gov.br/avalia4/home.htm.
} 
Table 7. Size and Projected Growth of Major Religious Groups in Latin America and the Caribbean, 2010-2050

\begin{tabular}{|c|c|c|c|c|c|c|c|}
\hline & $\begin{array}{l}2010 \text { ESTIMATED } \\
\text { POPULATION }\end{array}$ & \% IN 2010 & $\begin{array}{l}2050 \text { PROJEC TED } \\
\text { POPULATION }\end{array}$ & $\%$ IN 2050 & $\begin{array}{c}\text { POPULATION } \\
\text { GROWTH } \\
2010-2050\end{array}$ & $\begin{array}{c}\% \\
\text { INCREASE } \\
2010-2050\end{array}$ & $\begin{array}{l}\text { COMPOUND } \\
\text { ANNUAL } \\
\text { GROWTH } \\
\text { RATE (\%) }\end{array}$ \\
\hline Christians & $531,280,000$ & $90.0 \%$ & $665,500,000$ & $88.9 \%$ & $134,220,000$ & $25.3 \%$ & $0.6 \%$ \\
\hline Unaffiliated & $45,390,000$ & 7.7 & $65,150,000$ & 8.7 & $19,770,000$ & 43.6 & 0.9 \\
\hline Folk Religions & $10,040,000$ & 1.7 & $14,310,000$ & 1.9 & $4,270,000$ & 42.5 & 0.9 \\
\hline Other Religjons & 990,000 & 0.2 & $1,170,000$ & 0.2 & 180,000 & 18.4 & 0.4 \\
\hline Muslims & 840,000 & 0.1 & 940,000 & 0.1 & 100,000 & 12.5 & 0.3 \\
\hline Hindus & 660,000 & 0.1 & 640,000 & $<0.1$ & $-20,000$ & -3.5 & -0.1 \\
\hline Jews & 470,000 & $<0.1$ & 460,000 & $<0.1$ & $-10,000$ & -3.0 & -0.1 \\
\hline Buddhists & 410,000 & $<0.1$ & 450,000 & $<0.1$ & 40,000 & 8.6 & 0.2 \\
\hline Regional total & $590,080,000$ & 100.0 & $748,620,000$ & 100.0 & $158,540,000$ & 26.9 & 0.6 \\
\hline \multicolumn{8}{|c|}{$\begin{array}{l}\text { Source: The Future of World Religions: Population Growth Projections, } 2010-2050 \text {. Population estimates are rounded to the nearest } \\
10,000 \text {. Percentages are calculated from unrounded numbers. Figures may not add to } 100 \% \text { because of rounding. }\end{array}$} \\
\hline \multicolumn{8}{|c|}{ PEW RESEARCH CENTER } \\
\hline
\end{tabular}

Market religiosity in Brazil is especially intense in the Pentecostal and Neopentecostal milieu. The various denominations have explored media initiatives, social networks, and popular music such as funk, rap, and country to attract members. Competition, previously limited to external groups such as Catholics, Spiritists, and Afro-Brazilians, has started to occur between the Neopentecostal denominations themselves. In 2012, the evangelical market in Brazil moved 12 billion reais using exclusive credit cards and sector fairs with evangelical products and music. ${ }^{419}$ In the pluralistic process of offerings and internal competition, especially in the Neopentecostal milieu, being an evangelical means circulating among activities of various denominations, including temples, marches, shows, religious tourism, healing, and liberation sessions, making the dilution of denominational boundaries a characteristic of contemporary

${ }^{419}$ Camurça, “O futuro das religiões no Brasil,” 78-79. 
religiousness in the country. Facing the loss of members, traditional churches are being driven to the same market dynamics: one example is Catholic Charismatic Renewal. ${ }^{420}$

A characteristic of the Brazilian religious field is the absence of rigid borders between different religious expressions, allowing a kind of religious transit. ${ }^{421}$ Luiz points out that many Brazilians who regularly attend Umbanda terreiros are Catholic, and many who seek spiritual counseling are Catholic or evangelical. ${ }^{422}$ This phenomenon of religious simultaneity was confirmed by a 2000 survey carried out by the Center for Religious Statistics and Social Research (CERIS) in the six largest metropolitan regions of Brazil, which showed that 25 percent of respondents practiced more than one religion at the same time, and 12.5 percent practiced religious simultaneity always and continuously. ${ }^{423}$ Another survey conducted by Datafolha in 2016, with 5,700 people in 236 municipalities, found that 17 percent of respondents attended services outside their religious affiliation. ${ }^{424}$ For Luiz, this religious transit in force in Brazil is a characteristic of contemporaneity, which has allowed individuals to create a new way of being faithful, based on the fusion of various beliefs and religious experiences, mixed and acquired through the various options offered by the country's religious market. ${ }^{425}$

${ }^{420}$ Camurça, "O futuro das religiões no Brasil," 73.

${ }^{421}$ See Ronaldo A. Almeida and Paula Monteiro, “Trânsito religioso no Brasil," Scielo Analytics: São Paulo Perspectiva 15, no. 3 (July/September 2001): 92-101; Ronaldo A. Almeida and R. Barbosa, "Transição religiosa no Brasil," in Trajetórias das desigualdades: Como o Brasil mudou nos últimos cinquenta anos, ed. Martaed Arretche (São Paulo: Editora Unesp, 2015), 335-65.

${ }^{422}$ Luiz, “A religiosidade dos sem religião,” 74, 85.

${ }^{423}$ Luiz, “A religiosidade dos sem religião,” 85. See also Silvia Regina Alves Fernandes, “A (re)construção da indentidade religiosa inclui dupla ou tripla pertença," IHU Online, July 7, 2012, http://www.ihu.unisinos.br/entrevistas; Silvia Regina Alves Fernandes, Novas formas de crer: Católicos, evangélicos e sem religião nas cidades (São Paulo: CERIS-Promocat, 2009).

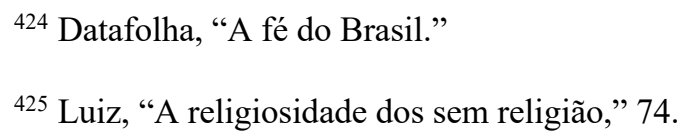


With similar reasoning, Patriota emphasizes that the present Brazilian religious experience is a reflection of modern religiosity, characterized by the individual's autonomous and subjective relationship with the sacred, and by the gradual decline of religious influence on social life. He also points out that the Brazilian religious market features a wide range of faith products, encouraging the country's "religious consumers" to choose like any other type of consumer, based on the criterion of individual preference. ${ }^{426}$

A 2004 CERIS survey of fifty Brazilian municipalities, on religious mobilization in the country, found that 24 percent of the population had changed their religion, and some had migrated from one religion to another up to six times. The survey also found that on average, the Catholic Church lost 1 percent of members in Brazil annually, and of every 100 people who abandoned Catholicism, 58.9 became Pentecostal. Of every 100 who left historical Protestant churches, 50.7 became Pentecostal, and of every 100 who stopped being Nones, 33.2 became Pentecostal. The higher the rates of religious mobilization and pluralism, the higher the growth of Pentecostals and Nones in Brazil, and for the latter, there is a general conception that faith does not require institutions. ${ }^{427}$

The religious switching resulting from freedom of choice and the multiple offers aimed at spiritual consumers mean that few people remain in the same religion as their parents. ${ }^{428}$ Inheritance of religious tradition gives way to a religiosity of a personal nature, in which

${ }^{426}$ Karla Regina Macena Pereira Patriota, "O show da fé: A religião na sociedade do espetáculo: Um estudo sobre a Igreja Internacional da Graça de Deus e o entretenimento religioso Brasileiro na esfera midiática" (doctoral thesis, Universidade Federal de Pernambuco, 2008), 82.

${ }^{427}$ Mobilidade Religiosa no Brasil, “Testemunho: Região episcopal sé.” See also Silvia Regina Alves Fernandes, "Trajetórias religiosas de jovens sem religião-algumas implicações para o debate sobre desinstitucionalização," Interseções 20, no. 2 (2018): 369-87, https://doi.org/10.12957/irei.2018.39029.

${ }^{428}$ Fernandes, "Sem religião," 383. 
individual choice is the primary factor. ${ }^{429}$ For Mariz and Machado, contemporary religiosity in Brazil can be summed up as hyper-individualization of choices, hybridization of beliefs and practices, and religious deinstitutionalization. ${ }^{430}$ In this context, Steil points out that new ways of believing in Brazil bring together, incorporate, and integrate elements from different traditions or sources, leaving the consumer with the task of synthesizing a personalized and eclectic menu of beliefs, with a minimum of institutional mediation. ${ }^{431}$

Pluralism and the transitional process have been considered a lever for the segment of the Nones in Brazil ${ }^{432}$ which may appear as the final stage of the various religious experiences lived by people who decide to break with institutionalized religiosity. ${ }^{433}$ The most traditional religious affiliations are in sharp decline, while the Nones are growing in proportion. Data points to a decline in Catholicism and denominations of historical Protestantism, especially Protestantism of immigration, such as Lutheranism, Presbyterianism, and Methodism. Churches of the Neopentecostal branch, such as the Universal Kingdom of God and the Congregation Christian, both founded in Brazil, are beginning to lose their strength of attraction (see Table 8). The growth of the Nones in the country reflects this process, to the extent that 95.2 percent of Nones do not classify themselves as atheists or agnostics, but exercise spirituality without connection

\footnotetext{
${ }^{429}$ Villasenor, "Crise institucional," 6.

${ }^{430}$ Mariz and Machado, "Mudanças recentes," 21.

${ }^{431}$ Steil, "Pluralismo, modernidade e tradição," 122. See also Datafolha, "Além da sua atual religião, você frequenta cultos ou serviços religiosos de alguma outra — de qual ou quais religiões?," 2017, http://media.folha.uol.com.br/datafolha/2013/05/02/religiao_03052007_1.pdf.

${ }^{432}$ Alves et al., "Distribuição espacial da transição," 218.

${ }^{433}$ See Table 1; see also Oliveira, "A desafeição religiosa de jovens," 4.
} 
with a religious institution. ${ }^{434}$

Table 8. Loss of Members Between 2000 and 2010 in Brazilian Main Churches

\begin{tabular}{|c|c|c|c|}
\hline Church & 2000 & 2010 & Difference \\
\hline Catholic & $125,518.774$ & $123,972.524$ & $-1.23 \%$ \\
\hline Lutheran & $1,062.145$ & 999,498 & $-5.9 \%$ \\
\hline Presbyterian & 981,064 & 921,209 & $-6.1 \%$ \\
\hline Methodist & 340,963 & 340,938 & $-0.01 \%$ \\
\hline God`s Universal Kingdom & $2,101,887$ & $1,873.243$ & $-10.88 \%$ \\
\hline Brazil`s Christian Congregation & $2,489,113$ & $2,289.634$ & $-8.01 \%$ \\
\hline
\end{tabular}

Source: IBGE Demographic Census, 2000 and 2010.

A religious survey conducted by the Vertex Institute in the metropolitan region of Belo Horizonte in 2012 found that comparing childhood religion with current religion, the Nones were the group that grew the most (500 percent). ${ }^{435}$ The research demonstrated not only the existence of accelerated religious transit in Brazil, but also that identifying as "None" is the final stage of religious experience for many, who, after going through various religious institutions, decide to manage their relationship with the supernatural without institutional assistance. ${ }^{436}$

In this context, the growth of "undetermined" or non-institutionalized evangelicals also draws attention. This population increased from 1,627,869 to 9,218,129 in Brazil between 2000 and 2010, rising from 6.21 percent to 21.8 percent of Protestants (see Table 7). In volume, they follow only Catholics, Pentecostal evangelicals, and Nones in the country. Studies show that the

\footnotetext{
${ }^{434}$ Instituto Brasileiro de Geografia e Estatística, Censo demográfico 2010, table 1.4.1.

${ }^{435}$ See Table 3.

${ }^{436}$ Panasiewicz, "Religião e Catolicismo em Belo Horizonte,” 1260, 1267.
} 
growth of this category within the Protestant branch has destabilized the growth of evangelical churches categorized as historical or missionary (Lutherans, Presbyterians, Methodists, Baptists, Congregationalists, and Seventh-day Adventists), as well as Pentecostals and Neopentecostals. The considerable increase in this group implied a decrease in both traditional Protestants and Pentecostals.

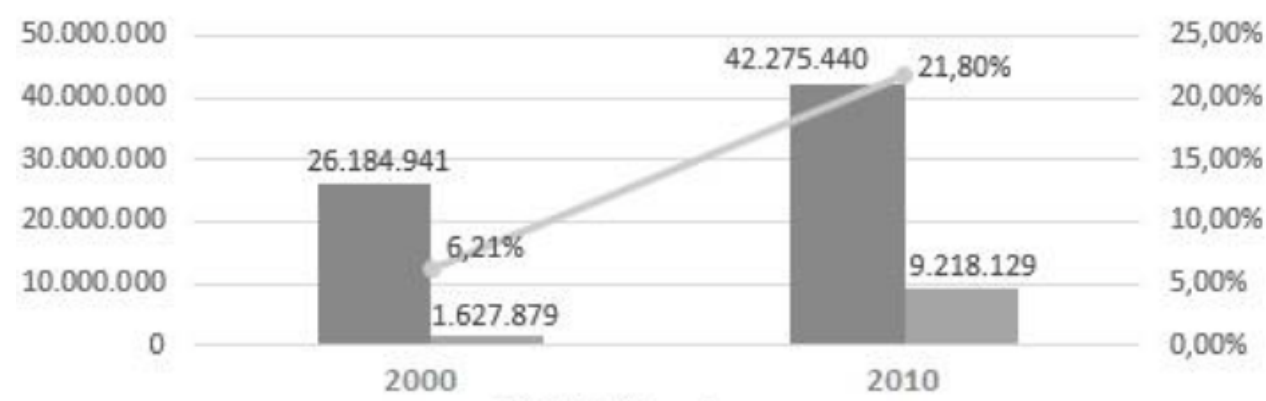

- Total evangelicals

Total undetermined evangelicals

Percentage of undetermined among the total number of evangelicals

Figure 5. Percentage of undetermined among evangelicals in the 2000-2010 census. Source: Douglas Alessandro Souza Santos, "Não-determinados? A pulverização evangélica e o problema metodológico do censo Brasileiro," Diversidade Religiosa 8, no. 1 (2018): 14. Translation by Jolive Chaves.

Santos points out that, although the IBGE census does not determine the precise identity of undetermined evangelicals, the group must include three categories of people, related to the Protestant universe. First, people who have "deviated" from denominations with which they were previously affiliated; second, people nominally linked to the evangelical environment by family tradition; and third, those who move among different denominations in the Protestant and 
evangelical context, but avoid institutional ties. ${ }^{437}$ Very similar to the Nones, they want to exercise an independent spiritual experience, not linked to a religious institution, although they identify with the principles of evangelical Protestantism. For Santos, this group is a reflection of the second modernity, or religious modernity, in which institutional boundaries are erased, giving rise to devotees who are not institutionalized or "disorganized"-who maintain their religious identity and belief, but outside institutions. ${ }^{438}$

On the American side, the religious market seems less pronounced than in Brazil, but religious pluralism is also a present reality, motivating research that points to the effects of religious diversity in the country. Draper, Froese, and Smith did a study on the effects and significance of interfaith contact in the United States, applied especially in a non-Christian context. The authors assessed the influence of interfaith contact on the variables of church attendance and spiritual effort. They wanted to know whether exposure to religious pluralism, especially related to non-Christian religions, influences a person's institutional commitment and spirituality. In general, their predictions point to a reduction in religiosity, leading to crises of faith. At the same time, there is an increase in religious confidence, as personal beliefs are contrasted with religious ideas from different traditions practiced by the person. However, Draper, Froese, and Smith concluded that face-to-face pluralism affects particular religions in the following way: First, religious pluralism increases religiosity or the engagement of the person with some religiosity. However, this is more because of the increased level of competition between organizations than because of individual choices. Thus, they say, organizations try to

${ }^{437}$ Douglas Alessandro Souza Santos, "Não-determinados? A pulverização evangélica e o problema metodológico do censo Brasileiro," Diversidade Religiosa 8, no. 1 (2018): 18.

${ }^{438}$ Santos, "Não-determinados," 18-19. See also Rodrigo Cardoso, "O novo retrato da fé no Brasilpesquisas indicam o aumento da migração religiosa entre os Brasileiros, o surgimento dos evangélicos não praticantes e o crescimento dos adeptos ao islã," ISTOÉ, August 24, 2011. 
prevent people from having contact with other religious experiences, fearing that they will be convinced and change their affiliation. Second, they concluded that exposure to religious diversity could decrease commitment to a particular religion, and at the same time, increase commitment to spirituality at the individual level. ${ }^{439}$

In another study on the effects of religious diversity in America, Merino points out that the majority of Americans believe the United States is a Christian nation and Christianity played a crucial role in the founding of the country. If, on the one hand, this perception is associated with the belief that religious diversity is good for America, on the other hand, those surveyed tended to associate religious diversity only with the Christian universe. Thus, non-Christian religions face resistance when seeking to be included in community religious life. Merino points out that interfaith contact is essential to lessen resistance to cross-cultural religiosity, but at the same time, it can further strengthen theologically exclusive beliefs. ${ }^{440}$

Contemporary religious pluralism in America is broad and involves diverse Christian denominations, non-Christian religions, and a variety of non-institutionalized beliefs and systems such as humanism, agnosticism, atheism, and subjective spirituality. ${ }^{441}$ Given this diversity, studies have shown that contact with different religions and philosophies of life has affected the religious outlook of Americans. First, personal religious beliefs are challenged as the person comes into contact with different ideas and points of view. According to the Pew Research

\footnotetext{
${ }^{439}$ Scott Draper, Buster G. Smith, and Paul Froese, "Religious Pluralism and the Individual: The Effects and Meaning of Inter-Religious Contact," Journal of Social Science Studies 2, no. 1 (December 3, 2014): 244-46.

${ }^{440}$ Stephen M. Merino, "Religious Diversity in a 'Christian Nation': The Effects of Theological Exclusivity and Interreligious Contact on the Acceptance of Religious Diversity," Journal for the Scientific Study of Religion 49, no. 2 (2010): 231-46.

${ }^{441}$ Daniel Cox, "Religious Diversity May Be Making America Less Religious," FiveThirtyEight (blog), August 23, 2016, https://fivethirtyeight.com/features/religious-diversity-may-be-making-america-less-religious/.
} 
Center, 77 percent of Americans are familiar with someone who is not religious, 61 percent with someone Jewish, and 38 percent with a Muslim. ${ }^{442}$ In this perspective, as a person comes to know new forms of religiosity, there is a weakening of personal religious identity, decreasing the conviction and certainty concerning the belief system practiced. When pluralism weakens religiosity, one consequence is an increase in Nones. ${ }^{443}$

Another consequence of Americans' contact with a wide variety of religious beliefs and values has been the weakening of the country`s collective vision of its Christian heritage. According to Cox, this weakening religious consensus results in less social pressure to maintain commitments to religion. ${ }^{444}$ Research by the PRRI Institute shows that new generations of Americans are placing less value on the country's Christian heritage and do not consider Christianity a critical factor for national identity. According to the institute, while 66 percent of people aged 65 and over say that being a Christian is central to American identity, among young adults aged 18 to 29 , the rate is 35 percent. Likewise, while 77 percent of the elderly consider belief in God as critical to American identity, the rate drops to 52 percent among young people. ${ }^{445}$

Analysis of the religious diversity of American states demonstrates how the religious perspective of the population is affected by religious pluralism. States with greater religious

${ }^{442}$ Pew Research Center, "U.S. Public Has Warmest Feeling for Jews, Catholics and Evangelicals," July 16, 2014, https://www.pewforum.org/2014/07/16/how-americans-feel-about-religious-groups/pf_14-0716_interreligiousrelations_totalratings $1 /$.

${ }^{443}$ Cox, "Religious Diversity," 2.

${ }^{444}$ Cox, "Religious Diversity," 2.

${ }^{445}$ Robert P. Jones and Daniel Cox, "Most Americans Believe Protests Make the Country Better; Support Decreases Dramatically among Whites If Protesters Are Identified as Black," PRRI, 2015, http://www.prri.org/research/survey-americans-believe-protests-make-country-better-support-decreasesdramatically-protesters-identified-black/. 
variety tend to show a lower general level of religiosity. Mississippi, known for its Baptist and evangelical majority population and low religious diversity, in 2016 was identified as the most religious state in the country, along with the state of Alabama. This takes into account the percentages of people who claim religion is essential for their lives, attend weekly religious services, practice daily prayer, and declare belief in God. ${ }^{446}$ On the other hand, the state of Oregon, ranked among the five least religious states in the country, ${ }^{447}$ has a high index of religious pluralism. In this state, no religious tradition has a reach higher than 20 percent of the population. ${ }^{448}$ A PRRI study demonstrates that Americans who have greater religious diversity among their close friends and family members show the least regular religious involvement, and are also the least likely to be involved in religious activities. In the study, 63 percent of Americans who claimed to have religious diversity in their social networks rarely or never attended religious services. Among those whose close friends and family members were of the same faith, only 32 percent rarely or never attended religious services. ${ }^{449}$

Finally, exposure to religious diversity in the family environment affects religious identity in American society. Americans who grew up with parents who professed different faiths reported having a lower level of involvement in religious activities in childhood than those who grew up with parents of the same faith: 40 percent of the first group and 58 percent of the

\footnotetext{
${ }^{446}$ Pew Research Center, "How Religious Is Your State," February 29, 2016, https://www.pewresearch.org/fact-tank/2016/02/29/how-religious-is-your-state/?state=alabama.

${ }^{447}$ Gallup, "Mississippi Retains Standing as Most Religious State,” February 8, 2017, https://news.gallup.com/poll/203747/mississippi-retains-standing-religious-state.aspx?version=print.

${ }^{448}$ Cox, "Religious Diversity," 3.

${ }^{449}$ Daniel Cox, Juhem Navarro-Rivera, and Robert P. Jones, "Race, Religion, and Political Affiliation of Americans' Core Social Networks," PRRI, August 3, 2016, https://www.prri.org/research/poll-race-religion-politicsamericans-social-networks/.
} 
second group participated in weekly religious services. Likewise, Americans who grew up in homes with mixed religions were less likely to practice regular prayer and Bible study with their families as adults, which can contribute to weakening people's religious identity and consequently that of the nation (See Figure 6).

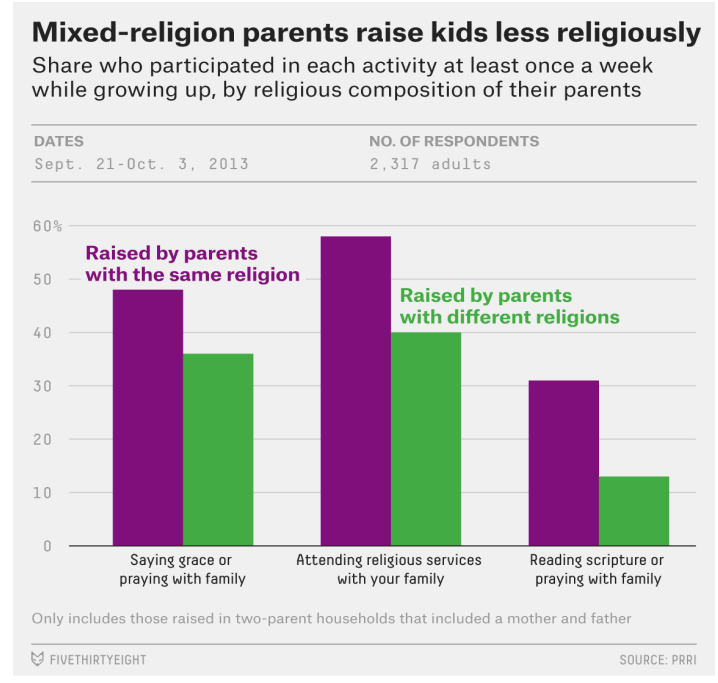

Figure 6. Mixed-religion parents raise kids less religiously.

From this perspective, the data show that, as it weakens received religious traditions and personal religious convictions, the religious pluralism experienced in American society contributes to the abandonment of institutional religiosity and increase in the number of Nones. ${ }^{450}$ As will be seen in the next section, some Nones opt for an eclectic and subjective religiosity, practiced on a personal level, without religious belonging, while others choose a secular life experience.

${ }^{450}$ Dick Houtman and Stef Aupers, "The Spiritual Turn and the Decline of Tradition: The Spread of PostChristian Spirituality in 14 Western Countries, 1981-2000," Journal for the Scientific Study of Religion 46, no. 3 (2007): 305-20. 
Table 9. Nones across Generations

\begin{tabular}{|l|c|c|c|}
\hline \multicolumn{1}{|c|}{ Generation } & 2007 & 2014 & Change \\
\hline Silent Generation (born 1928-1945) & $9 \%$ & $11 \%$ & +2 \\
\hline Baby Boomers (born 1946-1964) & $14 \%$ & $17 \%$ & +3 \\
\hline Generation X (born 1965-1980) & $19 \%$ & $23 \%$ & +4 \\
\hline Older Millennials (born 1981-1989) & $25 \%$ & $34 \%$ & +9 \\
\hline Younger Millennials (born 1990-1996) & $\mathrm{n} / \mathrm{a}$ & $36 \%$ & $\mathrm{n} / \mathrm{a}$ \\
\hline
\end{tabular}

Source: Pew Research Center, "Millennials Increasingly Are Driving Growth of 'Nones."”

As in Brazil, it is evident that religious pluralism in America has its greatest effect on the younger generations, who are the most affected by cultural trends. Therefore, although the Nones are growing in each US generation, they have grown most among younger generations, leading scholars to point out that generational replacement is one of the causes for the growth of the Nones in the country. Whether comparing the same generations in different years or comparing younger generations with older ones, the growth trend of people who declare themselves as Nones is always maintained. The liveliest growth is in the younger millennial generation (36 percent of the representatives of that generation declared themselves Nones in 2014). Other studies point out that younger millennials in the US are far less likely than older Americans to identify with a religious group, and that as time goes on, the already large share of religiously 
unaffiliated millennial adults is increasing significantly. Most millennials who were raised without a religious affiliation are religious Nones in adulthood (67 percent). ${ }^{451}$

The Nones are the fastest-growing group in the United States, compared to traditional religions, while Catholics are the group losing the most members. For every person who becomes a Catholic, 6.5 leave the church in America. On the other hand, the Nones gain 4.2 people for every person that leaves the group. Among Protestant groups, only evangelicals have a small growth rate, on the order of 1.2 converts to 1 leaving. Black Protestants lose 1.6 and mainline Protestants lose 1.7 members for each person who joins the groups (see Figure 7). Further, while they have increased in percentage in America, the Nones have decreased in measures of religiosity over time.

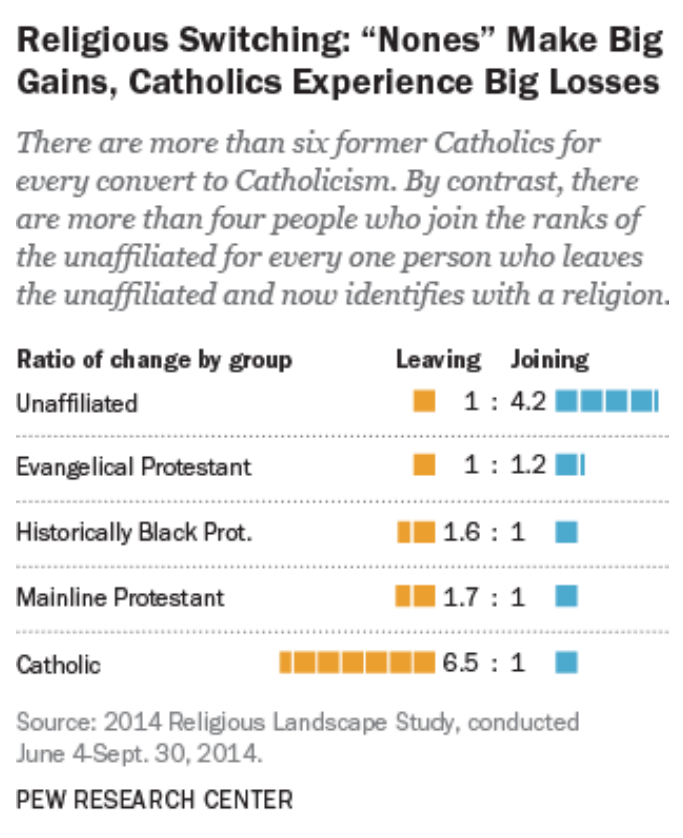

Figure 7. Religious switching: Nones make big gains, Catholics experience big losses.

${ }^{451}$ Pew Research Center, "Millennials Increasingly." 
The switching process, which is very common in the context of religious pluralism, has been favorable to nondenominational Protestants in the United States as well as undetermined evangelicals in Brazil, whose growth has leaped in recent decades. In a Pew Research Center survey in 2014 (see table 10), the nondenominational group benefited the most from religious switching among Protestants. That year, 2 percent of adult Americans identified it as their childhood affiliation, compared to 6.2 percent who said they now belonged to that group. While 1.1 percent of childhood nondenominational Protestants had left the group, 5.3 percent of current members had joined the group from another childhood denomination.

\section{Table 10. Many Protestant Denominational Families Lose More Adherents Than They Gain via Religious Switching}

Percentage of all U.S. adults who were raised in, left, entered and currently identify with each group

\begin{tabular}{lcccc} 
& Childhood religion & Leaving group & Entering group & Current religion \\
Baptist & $\%$ & $\%$ & $\%$ & $\%$ \\
Methodist & 19.2 & -8.4 & +4.5 & $=15.4$ \\
Nondenominational & 6.5 & -3.9 & +2.0 & $=4.6$ \\
Lutheran & 2.0 & -1.1 & +5.3 & $=6.2$ \\
Presbyterian & 4.9 & -2.4 & +1.0 & $=3.5$ \\
Pentecostal & 3.0 & -2.0 & +1.1 & $=2.2$ \\
Anglican/Episcopalian & 4.0 & -2.0 & +2.6 & $=4.6$ \\
Restorationist & 1.8 & -1.1 & +0.6 & $=1.3$ \\
Congregationalist & 1.9 & -1.1 & +1.0 & $=1.9$ \\
Holiness & 0.9 & -0.6 & +0.3 & $=0.6$ \\
Reformed & 1.1 & -0.7 & +0.5 & $=0.8$ \\
Adventist & 0.3 & $-<0.3$ & $+<0.3$ & $=<0.3$ \\
Anabaptist & 0.6 & -0.3 & +0.3 & $=0.6$ \\
Pietist & 0.4 & $-<0.3$ & $+<0.3$ & $=0.3$ \\
Friends/Quakers & $<0.3$ & $-<0.3$ & $+<0.3$ & $=<0.3$ \\
Other evangelical/fundamentalist & $<0.3$ & $-<0.3$ & $+<0.3$ & $=<0.3$ \\
Protestant, non-specific & $<0.3$ & $-<0.3$ & $+<0.3$ & $=0.3$ \\
NET Protestant & $\underline{3.2}$ & -2.3 & +2.9 & $=3.8$ \\
2014 Religjous Landscape Study, conducted June 4 - Sept. 30,2014 . Nested figures may notadd to subtotals indicated due to rounding, The \\
figures for those leavingand entering each Protestant familydo notsum to the total leavingand entering Protestantism as a whole because \\
they include people who move from one family to another within Protestantism. & & \\
PEW ReSEARCH ceNTER & & & & \\
\hline & & & & \\
\hline
\end{tabular}


American Nones have more secular tendencies than those in Brazil. The vast majority are not looking for a church or religious group to join. Excluding atheists and agnostics, only 10 percent of Nones in the country say they are looking for a religion that is right for them, compared to 88 percent who say they are not. ${ }^{452}$ In addition, only 28 percent say they think it is essential to belong to a community of people who share values and beliefs..$^{453}$

Therefore, it can be said that, with young people being the most susceptible to cultural influences, the younger generations in both countries are the most affected by religious pluralism, and for this reason, the Nones achieve more significant growth among this age group. It is also evident that the religious market is stronger in Brazilian society than in American society, but in both, religious pluralism has precipitated the growth of the Nones. Identifying as None can be the final stage of a search process, in which people go through various religious affiliations without having their needs met and then opt for an individual relationship with the transcendent. The Nones' growth may also be associated with modern and postmodern concepts such as the weakening of institutional religion, the privatization of religion, and even the secularization of society.

\section{Emphasis on Spiritualizing Religion}

In both Brazilian and American society, there has been a noticeable movement toward detachment from institutional religiosity in favor of an independent, personal, and subjective religiosity. Among American Nones, 37 percent say they are spiritual but not religious

\footnotetext{
452 Pew Research Center, “U.S. Religious Landscape Survey: Religious Beliefs and Practices,” June 1, 2008, https://www.pewforum.org/2008/06/01/u-s-religious-landscape-survey-religious-beliefs-and-practices/.

453 Pew Research Center, "Nones on the Rise."
} 
(SBNR) ${ }^{454}$ This statement alludes to the fact that they are looking beyond the churches for answers to life's most profound questions. It also shows that they are disillusioned with religious institutions and traditional devotional practices. They want the benefits of believing and loving God without committing to religious organizations. Above all, this attitude is a reflection of the pluralistic influences of contemporary society, with an emphasis on the autonomy of the individual and relativism. ${ }^{45}$

In a survey presented by Wuthnow, when adults between twenty-one and thirty-nine years old were faced with a choice between personal experience and church doctrines, about 70 percent chose personal experience. ${ }^{456}$ Wuthnow also found that young adult Nones who say they are interested in spirituality tend to be closer to their thirties than to their twenties, are more likely married than single, and are more likely to have children. Thus, the author concludes that marriage and parenthood seem to contribute to not only the engagement of young adults with institutional religion, but also the increased search for spirituality among those who consider themselves Nones. ${ }^{457}$

The group that declares themselves SBNR in America has a broad base, including adult Americans of both sexes; white, black, and Hispanic people; and both Democrats and

\footnotetext{
${ }^{454}$ This is Miller's definition of contemporary spirituality and religion: "Spirituality is the 'felt' dime relationship to the divine, while religion is a prepackaged bundle of tools that can help one access and foster that relationship. Religion is understood as essentially institutionalized - a given religion a name, an identifiable group of believers, a physical nexus, and a shared set of beliefs or dogma — while spirituality might occur within or institutional framework." Miller, "Spiritual but Not Religious," 855.

${ }^{455}$ Miller, "Spiritual but Not Religious," 855.

${ }^{456}$ Wuthnow, After the Baby Boomers, 133, 135.

${ }^{457}$ Wuthnow, After the Baby Boomers, 134.
} 
Republicans. Furthermore, SBNRs have grown not only among the Nones but also among Protestants, Catholics, and those who identify with other religions (see Table 11 and Figure 8). 


\section{Table 11. Most of Those Who Say They Are Spiritual but Not Religious Also Identify with a Religious Group}

\begin{tabular}{|c|c|c|c|c|c|}
\hline & $\begin{array}{l}\text { U.S. } \\
\text { adults }\end{array}$ & $\begin{array}{l}\text { Religious } \\
\text { and } \\
\text { spiritual }\end{array}$ & $\begin{array}{c}\text { Religious } \\
\text { but not } \\
\text { spiritual }\end{array}$ & $\begin{array}{l}\text { Spiritual } \\
\text { but not } \\
\text { religious }\end{array}$ & $\begin{array}{c}\text { Neither } \\
\text { religious } \\
\text { nor spiritual }\end{array}$ \\
\hline$\%$ who identifyas ... & $\%$ & $\%$ & $\%$ & $\%$ & $\%$ \\
\hline Protestant & 46 & 63 & 47 & 35 & 18 \\
\hline Catholic & 21 & 24 & 37 & 14 & 19 \\
\hline Unaffiliated & 22 & 4 & 6 & 37 & 54 \\
\hline Other & 8 & 8 & 8 & 11 & 7 \\
\hline \multirow[t]{2}{*}{ Don't know/refused } & $\underline{2}$ & 1 & $\underline{2}$ & $\underline{3}$ & $\underline{3}$ \\
\hline & 100 & 100 & 100 & 100 & 100 \\
\hline \multicolumn{6}{|c|}{$\%$ who say they attend religious services ... } \\
\hline Weekly or more & 35 & 55 & 36 & 17 & 8 \\
\hline Monthly/yearly & 31 & 31 & 40 & 32 & 27 \\
\hline Seldom/never & 33 & 13 & 20 & 49 & 63 \\
\hline \multirow[t]{2}{*}{ Don't know/refused } & $\underline{1}$ & $\underline{1}$ & $\underline{3}$ & $\underline{2}$ & $\underline{2}$ \\
\hline & 100 & 100 & 100 & 100 & 100 \\
\hline \multicolumn{6}{|l|}{$\%$ who say religion is ... } \\
\hline Very important & 50 & 79 & 49 & 27 & 11 \\
\hline Somewhat important & 23 & 18 & 35 & 27 & 26 \\
\hline $\begin{array}{l}\text { Not too/not at all } \\
\text { important }\end{array}$ & 25 & 3 & 14 & 44 & 61 \\
\hline \multirow[t]{2}{*}{ Don't know/refused } & $\underline{1}$ & $\leq 1$ & $\underline{2}$ & $\underline{2}$ & $\underline{3}$ \\
\hline & 100 & 100 & 100 & 100 & 100 \\
\hline \multicolumn{6}{|c|}{$\begin{array}{l}\text { Note: Figures may not add to } 100 \% \text { due to rounding. Results for U.S. adults based on the } \\
\text { random half of respondents who were asked whether theyconsider themselves to be a } \\
\text { religious person and whether theyconsider themselves to be a spiritual person. } \\
\text { Respondents were asked separate questions about whether theyconsider themselves to be } \\
\text { "a religious person" and whether theyconsider themselves to be "a spiritual person." The } \\
\text { "spiritual but not religjous" category includes those who responded affirmatively to the } \\
\text { question about being spiritual person and also responded that they do not consider } \\
\text { themselves to be a religious person. } \\
\text { Source: Survey conducted April } 25 \text {-June 4, } 2017 \text {. }\end{array}$} \\
\hline
\end{tabular}


$\%$ of U.S. adults who identify as spiritual but not religious

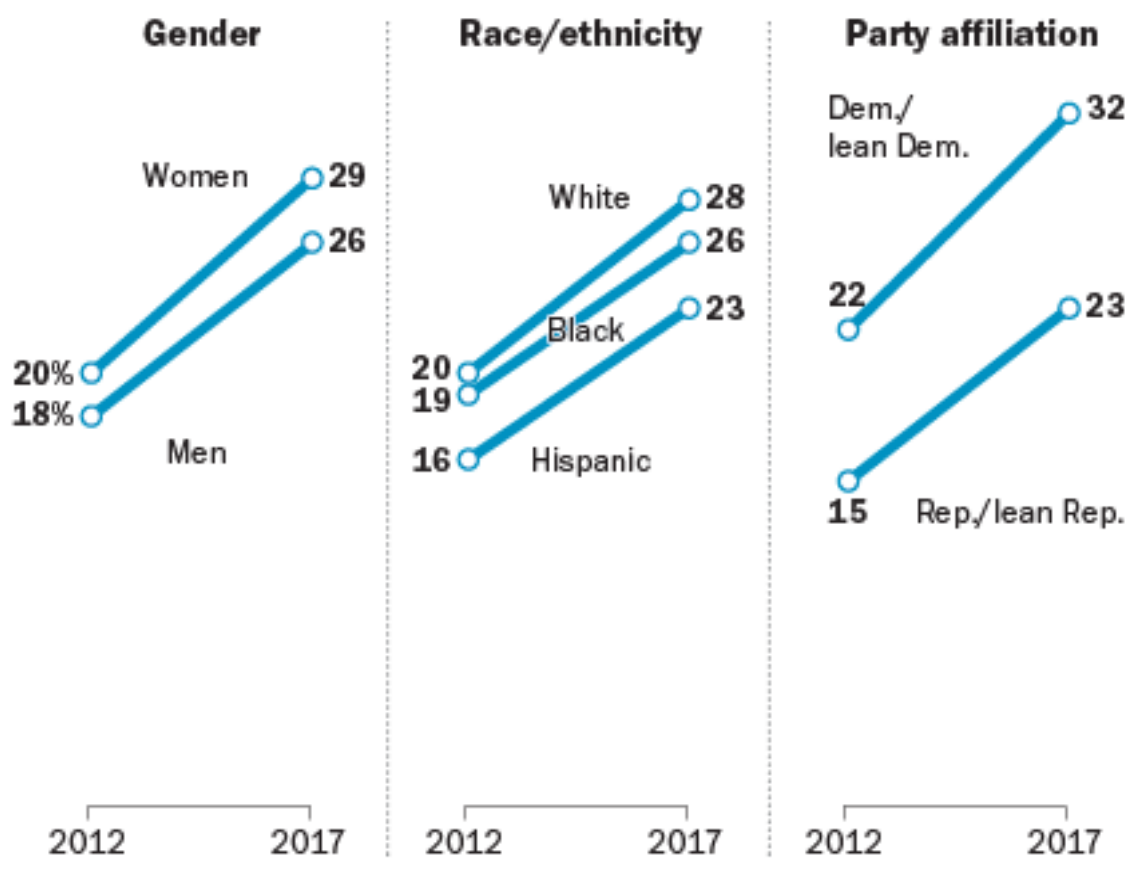

Note: Respondents were asked separate questions about whether they consider themselves to be "a religious person" and whether they consider themselves to be "a spiritual person." The "spiritual but not religious" category includes those who responded affirmatively to the question about being a spiritual person and also responded that they do not consider themselves to be a religious person. Whites and blacks include only those who are not Hispanic. Hispanics can be of any race. Source: Survey conducted April 25-June 4, 2017.

PEW RESEARCH CENTER

Figure 8. Increase of "spiritual but not religious" is broad-based. 
Adding the 48 percent of Americans who in 2017 said they were religious and spiritual to the 6 percent who said they were religious but not spiritual, one gets 54 percent of Americans who classify themselves as religious. In 2012, it was 65 percent - an eleven-point drop in five years. Using the same reasoning -48 percent who declared themselves religious and spiritual plus 27 percent who declared themselves spiritual but not religious -75 percent of Americans in 2017 declared themselves spiritual. ${ }^{458}$ There is a growing trend of opting for spirituality over religion, reflecting the wave of individualized religiosity or spirituality without an institutional basis - eclectic, relativistic, and with diluted theological content — that is present in Berger's description of religious pluralism. ${ }^{459}$

In his book on the unchurched in America, Fuller points out that a characteristic of this group is pluralistic religious practice, most often in a particular setting. He describes, for example, the experience of a teacher of Catholic origin who went to church very rarely, but who, maintaining her spirituality in the private sphere, practiced a combination of traditional and nontraditional elements in an eclectic setting. ${ }^{460}$ This same trend is seen on the Brazilian side. Although Brazil is considered a modern country in its structural sphere, maintaining its constitutive elements on a rational, bureaucratic, and secular basis, ${ }^{461}$ in the daily lives of its inhabitants there has been a massive and growing search for religious practices without

${ }^{458}$ See Table 8; see also Pew Research Center, "More Americans Now Say."

${ }^{459}$ Berger, The Sacred Canopy, 203-4; Berger and Zijderveld, In Praise of Doubt, 147-48. See also Paul Heelas, "The Spiritual Revolution: From Religion to Spirituality," in Religions in the Modern World: Traditions and Transformations, ed. Linda Woodhead et al. (London: Routledge, 2005).

${ }^{460}$ Robert C. Fuller, Spiritual, but Not Religious: Understanding Unchurched America (New York: Oxford University, 2001), 2.

${ }^{461}$ Pierucci and Prandi, A realidade social, 23. 
necessarily maintaining a commitment to institutional belonging. ${ }^{462}$ In this context, Brandão attests that "the image of the sacred today seems more resistant to the crises of postmodernity than the sciences and ideologies. This phenomenon of returning to the sacred, now coated with extraordinary plasticity, with a previously unthinkable power of creation and differentiation, involves the most diverse people, social groups, and cultural communities." ${ }^{\prime 63}$

For Pierucci, Brazil is experiencing what sociologists call the post-traditional period, and which he calls the late-modern period. According to Pierucci, in post-traditional societies, people tend to disengage from the old ties of belonging, triggering a process of disaffiliation in which social, cultural, and religious belonging become optional and inconsistent. ${ }^{464}$

In his book Modernidade líquida (Liquid Modernity), Bauman contrasts the rigidity and stagnation of the pre-modern period with the fluidity of the modern era. For him, as the principles established by modern thinking of freedom, emancipation, competitive open markets, and rapid changes are assimilated, societies become more and more like a fluid, which is always ready to change position and shape according to circumstances. "The extraordinary mobility of fluids is what associates them to the idea of lightness," he says, calling it an "appropriate metaphor" for the changing and renewing nature of contemporaneity that repudiates traditional loyalties and strives for flexibility and individual choices. He also argues that in this context of contemporary fluidity, any dense network of ties, barriers, and borders is seen as an obstacle to

462 Vilhena, "Religião e novos movimentos sociais," 1014.

${ }^{463}$ Carlos Rodrigues Brandão, "Ser Católico: Dimensões Brasileiras - um estudo sobre a atribuição da identidade através da religião," in Brasil e EUA: Religião e identidade nacional, ed. Roberto Damatta and Rubem Cesar Fernandes (Rio de Janeiro: Graal, 1988), 285.

${ }^{464}$ Antônio Flavio Pierucci, "Secularização e declínio do Catolicismo," in Sociologia da religião e mudança social: Católicos, Protestantes e novos movimentos religiosos no Brasil, ed. Beatriz Muniz de Souza and Luiz Mauro Sá Martino (São Paulo: Paulus, 2004), 19, 27. 
be eliminated. In this perspective, Bauman argues that the contemporary social context can be described as second modernity, modernization of modernity, super modernity, postmodernity, liquid modernity, and the era of instantaneity. ${ }^{465}$

Giddens describes the turn of the twentieth century to the twenty-first as a transition "beyond modernity" or into "second modernity," characterized by a reflexivity that generates active processes of self-identity, displacement of social life, the fixity of tradition and institutional beams, a plurality of demands, and a profound speed of change. ${ }^{466}$ Alves uses "liquid or late modernity" to refer to the postmodern characteristics that explain the structural transformations of Brazilian society in the current period, when rigid and static religious traditions and practices are being replaced by a more fluid, instantaneous, and mobile experience. ${ }^{467}$ Renders recognizes that the process of accelerating time applied to what he calls "late modernity" corresponds to contemporary religious experiences with instant characteristics and an emotional and ecstatic nature. ${ }^{468}$

Novaes and Capello did a study in 2001 called "Jovens do Rio," in which they interviewed eight hundred young people between fifteen and twenty-four years old from that Brazilian state. Among the subjects researched was the theme of religion and beliefs. The researchers found that 21.2 percent of these young people declared they had no religion, well $51,132-33$.

${ }^{465}$ Zygmunt Bauman, Modernidade líquida (Rio de Janeiro: Jorge Zahar, 2001), 8-46.

${ }^{466}$ Anthony Giddens, As consequências da modernidade (São Paulo: Editora da Unesp, 1991), 9, 12, 50,

${ }^{467}$ Alves et al., "Distribuição espacial da transição," 236.

${ }^{468}$ H. Renders, "A experiência religiosa pós-moderna e o fenômeno da aceleração em comparação com as temporalidades pré-moderna e moderna," Revista Horizonte 37, no. 13 (2015): 428. 
above the national averages of 7.2 percent (2000) and 8.04 percent (2010). ${ }^{469}$ According to the authors, 15.9 percent of young people surveyed who claimed to have no religion also reported belief in God, Jesus Christ, the Holy Spirit, angels, the Virgin Mary, and/or spirits. The young people interviewed showed a strong disposition to change their religion, and emphasized the value of individual religious choice in addition to a religiosity without institutional ties. ${ }^{470}$

A national survey carried out in 2004 by the Citizenship Institute of the federal government of Brazil, with 3,500 young people between fifteen and twenty-four years old, showed that 10 percent declared themselves "without religion," with 9 percent saying they believed in God but had no religion, and only 1 percent identifying themselves as atheists or agnostics. ${ }^{471}$ For Novaes, these young people without religion but with a belief in God are part of the same Brazilian group that says they are spiritual without religion: that is, adherents of noninstitutional forms of spirituality that are typically classified as esoteric, new age, holistic, or deep ecology. ${ }^{472}$ Novaes points out that this group, nowadays, is being challenged to make choices in the religious field in a plural and competitive context. For her, there is a peculiar environment, or a "period spirit," in which people are encouraged to adhere to a diverse belief system combining Western and Eastern practices, both religious and therapeutic or medicinal. Novaes highlights the growth in Brazil of Buddhism, Judaism, Islam, exoteric religions, and

${ }^{469}$ Instituto Brasileiro de Geografia e Estatística, "Religião: Séries históricas e estatísticas, população por religião; população presente e residente," accessed February 13, 2018, https://seriesestatisticas.ibge.gov.br/series.aspx?vcodigo=POP60.

${ }^{470}$ Regina Novaes and Cecília Mello, “Jovens do Rio: Circuitos, crenças, acessos,” Comunicações do ISER 21 no. 57 (2002): 30-37.

${ }^{471}$ Governo do Brazil: Instituto Cidadania, "Projeto juventude: Documento de conclusão,” 2004, https://registrojuventude.files.wordpress.com/2011/02/dicas-projeto-juventude-final-1.pdf.

${ }^{472}$ Novaes, “Os jovens sem religião,” 323. 
indigenous traditions, in addition to religious practices of African origin, which, together with Catholicism, Protestantism, and Pentecostal and Neopentecostal evangelicalism, form an unprecedented combination. Novaes points out that, in this plural religious world, the number of people and groups whose religious adherence allows provisional arrangements between beliefs and rites without institutional fidelity grows, highlighting individuality and religious syncretism. ${ }^{473}$

In this syncretic perspective, Novaes points out that there is a weakening of ties of religious belonging and the theological content of beliefs. Many of the young people interviewed in her study saw it as natural to be Catholic and at the same time attend spiritual centers of African origin, and even to hold a combination of mediumistic beliefs and practices with others coming from the context of the new era. For Novaes, this weakening of ties and religious syncretism are factors that propitiate the growth of the Nones, as they mean belief without belonging. Religious choices are based on personal taste and without institutional criteria. Novaes points out that young people without religion said they believed in practically all items presented: energy, astrology, orishas, elves, and gnomes, in addition to angels, the Holy Spirit, and others. ${ }^{474}$

Novaes emphasizes that the contemporary generation of young Brazilians has the option of declaring themselves without religion while not giving up faith, through the consumption of religious goods as cultural expression, without institutional mediation or submission to religious authorities. In this context, the Bible is widely accessible to all; its verses are sung in rap lyrics and appear written on billboards and walls, as well as in expressions of art and culture related to

\footnotetext{
${ }^{473}$ Novaes, “Os jovens sem religião,” 325-26.

${ }^{474}$ Novais, “Os jovens sem religião,” 327.
} 
youth. As an example, Novaes points out that the Hutus award, considered the most important hip hop award in Latin America, rewards compositions without religion or institutional viability that speak of Christ and orishas and quote biblical psalms. ${ }^{475}$

Therefore, Brazil's religious profile includes pluralism and religious fragmentation typical of modern dynamics manifested through the multiplication of the religious universe, subjectivity, and the establishment of the individual as a measure and an end. ${ }^{476}$ Although Luiz says that this religious profile is specific to the Brazilian scenario, ${ }^{477}$ studies in several other countries and contexts have shown that believing without belonging, or being spiritual without being religious, is typical in contemporary times. It includes a great number of those who declare themselves to be Nones, regardless of where they are located. ${ }^{478}$

The rising popularity of SBNR in America and Brazil fits what Roof calls "lived religion," emphasizing the experimental quality of spirituality. ${ }^{479}$ Gedicks understands that contemporary spirituality, in essence, is a representation of postmodern belief. ${ }^{480}$ SBNRs are also

${ }^{475}$ Novaes, "Os jovens sem religião," 328.

${ }^{476}$ Steil, "Pluralismo, modernidade e tradição," 106.

${ }^{477}$ Luiz, “A religiosidade dos sem religião," 80.

${ }^{478}$ In general, the phrases "believe without belonging" and "spiritual, but not religious" have the same meaning: to maintain beliefs according to personal and individualized choices, regardless of religious institutions. Grace Davie argues that this is an element of secularization among the Western population. See Davie, Religion in Modern Europe, 69; Davie, Sociology of Religion, 44. See also Pew Research Center, "Nones on the Rise"; Pew Research Center, "When Americans Say."

${ }^{479}$ Wade Clark Roof, A Generation of Seekers (New York: Harper Collins, 1993), 33, 41.

${ }^{480}$ Frederick Mark Gedicks, "Spirituality, Fundamentalism, Liberty: Religion at the End of Modernity," DePaul Law Review 54, no. 1 (2005): 1197-1208. 
called "metaphysical believers," ${ }^{481}$ unchurched people," ${ }^{482}$ "spiritual seekers," 483 or adherents of "New Age spirituality" "484 and "religion á la carte," 485 among others. The most striking feature of this group is belief without belonging. ${ }^{486}$ SBNRs also do not accept purely secular alternatives. For them, a scientific and atheistic worldview is insufficient to give meaning and direction to human life. They advocate a worldview that recognizes existence on both the earthly and cosmic levels. ${ }^{487}$ The group also advocates an eclectic spirituality driven by individual choices, using the free market criterion: beliefs and practices are chosen based on the meaning and benefits they provide for life on a personal level. ${ }^{488}$

Another element present in the SBNR context is tolerance for religious diversity and acceptance of a multiplicity of beliefs. In this perspective, each person freely creates a system of spiritual enrichment, beliefs, and practices, extracted from whatever sources are available in the religious market. ${ }^{489}$ Roof points out that SBNRs focus on inner, subjective, and experiential spirituality. External aspects of religion, such as dogmas, leaders, other people, or even an

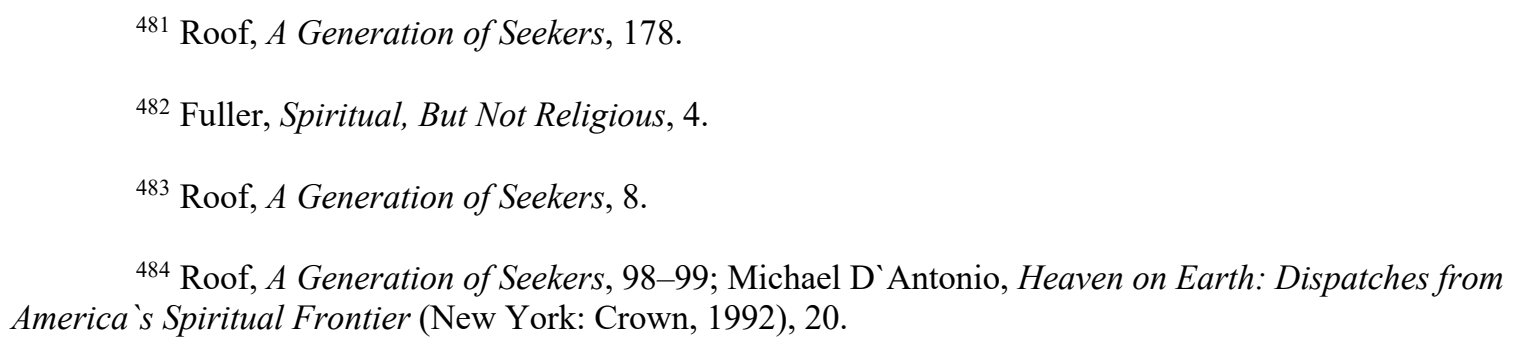
November 3, 2015, https://www.pewforum.org/2015/11/03/u-s-public-becoming-less-religious/.

${ }^{487}$ Fuller, Spiritual, But Not Religious, 19; Roof, A Generation of Seekers, 35.

${ }^{488}$ Roof, A Generation of Seekers, 57; Fuller, Spiritual, But Not Religious, 155; Gedicks, “Spirituality, Fundamentalism, Liberty," 1218.

${ }^{489}$ Miller, “Spiritual but Not Religious,” 860. 
external God, are left in the background or rejected. ${ }^{490}$ Furthermore, the SBNRs' religiosity is metaphysical, which means that their beliefs and practices aim for understanding and connecting with a realm beyond the physical from a postmodern perspective-relativistic, personal, deinstitutionalized, eclectic, pluralistic. ${ }^{491}$ The metaphysical perspective of postmodern religiosity is relativistic and rejects any doctrine that intends to establish a single true description of reality. ${ }^{492}$ However, Gedicks argues that there is a contradiction in postmodern thinking: it condemns Christianity and the Enlightenment for defending true universal metanarratives or narratives, but at the same time creates a universal narrative. For example, postmodernism offers religious pluralism as a universal narrative to replace modernity, in which each religion, from a particular perspective, can understand its beliefs as a metanarrative, applicable to the whole world. ${ }^{493}$

Evidence indicates that the contemporary spirituality present in American and Brazilian society had its foundations laid at the end of the nineteenth century, through the rise of spiritualism. Scholars have especially connected it with the mysterious raids on the Fox family home in New York in 1847, as well as with the mesmerist experiences of Andrew Jackson Davis in 1843 in the New England region. ${ }^{494}$ The sisters Maggie and Kate Fox became national celebrities when, after hearing knocking sounds at their home in Hydesville, NY, they began to

${ }^{490}$ Roof, A Generation of Seekers, 310.

${ }^{491}$ Miller, "Spiritual but Not Religious," 863-64.

492 Gianni Vattimo, After Christianity (New York: Columbia University Press, 2002), 77.

493 Gedicks, "Spirituality, Fundamentalism, Liberty,” 1207.

${ }^{494}$ See Fuller, Spiritual, But Not Religious, 38-44; J. Arthur Hill, Spiritualism, Its History, Phenomena and Doctrine (New York: George H. Doran, 1919), 30-43; Bret Carroll, Spiritualism in Antebellum America (Bloomington, IN: Indiana University Press, 1977), 3, 16-34; Ann Braude, Radical Spirits: Spiritualism and Women's Rights in Nineteenth-Century America (Boston: Beacon Press, 1989), 10-12, 169-72. 
communicate with an invisible spirit, snapping their fingers, clapping their hands, and later through a communication code. According to the Fox sisters, the spirit that made these rapping noises was that of a street vendor who had been murdered in the city and buried in the basement of the new house where they and their family were living. The event gained notoriety and started to be explored as "proof" of life after death and communication with spirits. ${ }^{495}$

Andrews Jackson Davis`s experience provides even more elements to understand the emergence of spiritualism and its reflection in contemporary spirituality. ${ }^{496}$ In his search for a religious identity, Davis first attended the Presbyterian Church, then the Methodist, and was later introduced to Universalism, but did not identify with any of the experiences. ${ }^{497}$ In 1843 , he met a mesmerist, who gave him literature and presented him with demonstrations of animal magnetism. Davis went on to help as a volunteer in the presentations that followed, and soon began to experience profound levels of mesmeric trance. Hypnotized, he was able to read books blindfolded, telepathically receive thoughts from people in the audience, and travel clairvoyantly to distant locations, which earned him a professional career as a mesmerist and medium. At first, he needed a hypnotist, but soon he was able to enter a self-induced trance in which he received messages from spirits that he channeled into words and recorded and transcribed in books. Davis`s psychographic writings became a source of theological principles for spiritualist philosophy, which viewed God as impersonal energy or intelligence and the universe as a set of causal spheres in which energies flowed from the upper to the lower spheres. Furthermore, Davis`s writings spread the idea that each person could become a channel through which

${ }^{495}$ Hill, Spiritualism, Its History, 40-43.

496 See Andrew Jackson Davis, The Magic Staff: An Autobiography of Andrew Jackson Davis (New York: J. S. Brown, 1857).

${ }^{497}$ Andrew Jackson Davis, The Great Harmonia (Boston: Mussey, 1852), 2:26, 27, 31. 
spiritual power flowed from the higher realms to the physical world, through internal connection with the higher spiritual realms. ${ }^{498}$

At some point in his experience, Davis was instructed by Emanuel Swedenborg. ${ }^{499} \mathrm{He}$ absorbed his metaphysical teachings of correspondence and influx based on each person's inner divinity, the essential continuity between the material and the spiritual world, and the belief in spirits inhabiting higher spheres of existence with whom humans could communicate. Thus, through Davis, spiritualism absorbed concepts from mesmerism, complemented by the principles of Swedenborgianism and Transcendentalism. ${ }^{500}$

In his explanation of the influence of nineteenth-century spiritualism on contemporary America, Fuller says that many Protestants were attracted to the possibility of direct communication with celestial beings and greater spiritual comfort, breaking the loneliness of the traditional Protestantism that dominated American religion, with its vision of a transcendent, distant, impersonal God. Davis's ideas about communicating with spirits to receive comfort and direction appealed to a broad spectrum of Americans dissatisfied with the predominant religion of their time. ${ }^{501}$ Furthermore, spiritualism's apparent potential to reconcile religion and science, insofar as it claimed to scientifically prove the existence of life after death by empirical demonstration, was attractive to many people..$^{502}$

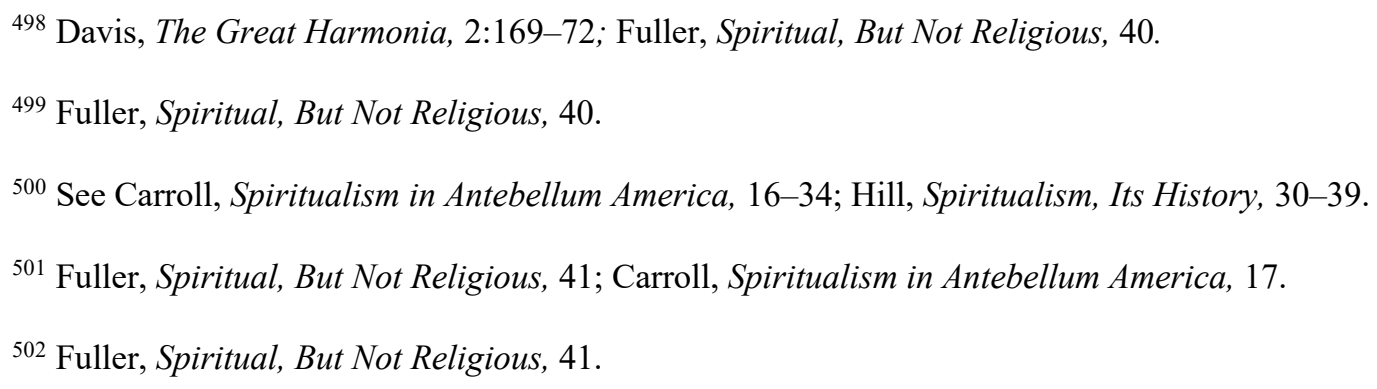


However, perhaps the clearest link between spiritualism and contemporary spirituality is an antagonistic view of churches. Nineteenth-century spiritualists saw churches as emotionally and intellectually stifling. People were encouraged to declare independence from all politics, with an emphasis on republicanism, and from every ecclesiastical institution. ${ }^{503}$ Adherents of spiritualism accused the churches of being rigid, conservative, and superficial and taking away people`s freedom and individuality. For them, genuine spirituality was individualized and necessary for them to recover their potential as bearers of divine inspiration. ${ }^{504}$ Fuller points out that spiritualism, together with Swedenborgianism, Transcendentalism, and mesmerism, ended up creating the first "metaphysical awakening" in American religious life. This metaphysical system particularly appealed to the middle class, as a means of preserving the core values of American culture, freeing them from the rigidity of churches, and simultaneously accommodating their religious values to the principles of modernity. ${ }^{505}$

\section{Summary of Category 3}

Religious pluralism is profoundly rooted in Brazilian and American societies, supported by legislation and by the democratic principles that prevail in both countries, giving ample religious freedom in the conception of a secular state. According to the above studies, some of the main consequences of religious pluralism in Brazilian and American societies are linked to the religious market and the spiritualization of religiosity. The offering of religious products

\footnotetext{
${ }^{503}$ Carroll, Spiritualism in Antebellum America, 39.

${ }^{504}$ Carroll, Spiritualism in Antebellum America, 39.

${ }^{505}$ Fuller, Spiritual, But Not Religious, 52-53.
} 
based on the taste of customers rather than on biblical-theological factors and competition for members has weakened the content of religious faith. In addition, there has been a dilution of institutional boundaries and an increase in syncretic, ecumenical religiosity, guided by personal choices, without institutional influence. Customers create their own spiritual menus, regardless of the origin of the products, on an existential and metaphysical basis of spirituality. This process has been called hyper-individualization, hybridization, and deinstitutionalization, and generates the so-called unchurched, or spiritual but not religious, who represent 37 percent of the American Nones and most of the Brazilian Nones. The wave of contemporary spiritualization has its foundations in the nineteenth century, and is driven by the principles of freedom, individualization, and relativization in force in postmodernity, also called liquid or late modernity.

Religious pluralism stimulates not only competition for members but also religious switching, in such a way that religious tradition starts to give way to religiosity of a personal nature, often culminating in the abandonment of institutional belonging in favor of the Nones. On the Brazilian side, the biggest beneficiaries of this religious switching are Neopentecostal evangelicals and Nones, while on the American side, they are nondenominational evangelicals and Nones. Studies have also shown that religious pluralism decreases institutional and dogmatic religiosity, reducing people's commitment to a particular religion. At the same time, it encourages the search for spirituality, mainly due to the influence of the religious market and interfaith contact. In this sense, religious identity is weakened on a personal, family, denominational, or even national level, when thinking of Brazil as a country of Catholic culture and the United States as a country of Protestant culture. Some evidence also points out that 
religious pluralism affects not only attendance at religious services, but also personal religious activities such as prayer and reading the Bible.

Comparing the data noted above on the effects of religious pluralism in Brazilian and American cultures with the three theories presented at the beginning of this section, there appears to be little evidence to support the non-effect model. This theory says that religious pluralism does not interfere with people's religiosity, but the evidence points in a different direction, confirming that religious pluralism affects people's religiosity. The evidence does confirm the modernization model advocated by Berger, according to which religious pluralism decreases dogmatic and institutional religious commitment through cognitive contamination, and at the same time increases intrinsic spirituality based on personal preferences.

The religious economy model also seems to be supported by the evidence of religious pluralism in both countries, but not in its entirety. According to the theory, religious pluralism increases religious competition for supporters and generates more opportunity for choices, precipitating a more significant religious commitment. There is evidence of increased competition and more religious options, but not increased religious commitment. In this case, pluralism improves religion at the macro or organizational level, but can harm individual commitment to a single faith. The evidence shows an increase in subjective spirituality, but not in institutional religious commitment, or even in Christian practices of Bible reading and prayer.

For this reason, religious pluralism is directly associated with religious disaffiliation, and with the rise of the Nones, in two ways. Firstly, it fosters the growth of Nones who maintain spirituality on a personal level, disconnected from institutional relations. This break with dogmatic religion can be definitive or temporary, since some of the Nones remain seekers, and may at some point identify with a religious institution that fulfills their desires. Second, the 
number of Nones most affected by secularism increases at a slower pace. This group is composed of atheists, agnostics, and the religiously indifferent, who lead their lives in a secular way, without depending on the supernatural. Evidence shows that a highly pluralistic and competitive culture in the religious sphere encourages some to choose a secular perspective on life. Although this is a reality in both cultures, the trend toward secularization seems more significant on the American side than on the Brazilian side. Furthermore, in both countries, younger generations, most susceptible to cultural influences, are the most affected by religious pluralism, and make up the highest proportion of the Nones.

\section{Category 4: The Changing and Permanent Nature of Religion}

\section{Summary of the Topic}

Durkheim and his disciples defended the permanent and changeable nature of religion, theorizing that secularism would increase its expansion into new forms of expression instead of destroying it. For Durkheim, there are three reasons why religion will never disappear. First, it is part of human nature, being a source of life and security for people. Second, it has social value; for him, society is the soul of religion, and at the same time, religion has social causes. Third, science cannot replace religion as a source of life, nor can it deny it, because it is a reality. As for the changing nature of religion, Durkheim argued that under the influence of secularization and scientific advances, religion would take new forms of expression in society, to adapt to new demands and contexts. ${ }^{506}$ Following the Durkheimian concept, Wallis points out that contemporary religion is more rational, individualistic, and centered on the human being and democratic values because it reflects the current social structure and is a source of collective

\footnotetext{
${ }^{506}$ See Durkheim, Elementary Forms, 429, 432.
} 
identity. ${ }^{507}$ In turn, Stark pointed out that the theory of secularism failed to provide for irreversible mystical immunity, the elimination of belief in the supernatural, and attempts to make science the basis of moral judgment. ${ }^{508}$ Together with Bainbridge, Stark associated the process of secularization with the multiplication of sects, cults, and new forms of contemporary religious expression as part of the human search for rewards and compensators, which makes religion something indestructible and at the same time changeable in form. ${ }^{509}$

\section{Relating the Topic to the Nones in Brazil and the United States}

The permanent and changing nature of religion, as described in the secularization theories formulated by Durkheim and some of his disciples, can be seen in the broad religious pluralism present in Brazilian and American societies. The process of social transformation that both countries have undergone and the resulting multifaceted manifestations of religion attest that, for most of the population of both countries, religion is fundamental. At the same time, it changes form, adapting to contextual characteristics. In particular, the ascendancy of spiritual and syncretic forms of religion in both cultures, culminating in the growing percentage of Nones, attests to the changing nature of religion. However, the small growth trend of secularism in American culture, especially among the Nones, is an invitation to reflect on the permanence of religion.

${ }^{507}$ Wallis, Elementary Forms, 57-58.

${ }^{508}$ See Stark, “Secularization, RIP,” 250, 253-54.

${ }^{509}$ Stark and Bainbridge, Theory of Religion, 143-49, 312. 
Many scholars of religion in Brazil point out that religious movement among three main groups - Catholicism, Protestantism, and Nones, which represent about 95 percent of Brazilians - reflects modern and postmodern influences, and there may also be a cause-andeffect relationship between them, meaning that one is a stage before the other. A person may move from Catholic to traditional evangelical, then traditional Pentecostal, Neopentecostal, undetermined evangelical, and finally non-religious. ${ }^{510}$ The decrease in Catholics coincides with the accelerated growth of evangelicals and Nones. Evangelicals grew from 5.2 to 22.2 percent of the population between 1970 and 2010. In the same period, Nones went from 0.8 to 8.04 percent of Brazilians (see Table 1).

Brazil has undergone a series of transformations since the beginning of the twentieth century in a process of industrialization, urbanization, and secularization to meet modern demands, which resulted in profound social and religious changes for its population. There was a migratory explosion to urban centers, especially in the Southeast region, the most industrialized in the country, transforming the periphery of the largest cities into population pockets. With the opening of new agricultural frontiers, there was a significant migration from the South to the Central and North regions of the country. This population mobilization, and other contemporary factors associated with modernity and even postmodernity, are seen as directly associated with the growth of non-religious people, the growth of evangelicals, and the accelerated decrease in Catholicism in the country.

Catholicism maintained an almost exclusive hegemony in Brazil for about five hundred years, and it became the largest Catholic nation in the world, surpassing Italy in the second half

\footnotetext{
${ }^{510}$ Oliveira, "A desafeição religiosa de jovens," 4.
} 
of the twentieth century. ${ }^{511}$ However, in recent years, the Catholic Church has seen an dramatic drop in Brazilian members and has become a universal donor of members to other churches. ${ }^{512}$

The most considerable decrease in Catholicism coincides with growth among evangelicals, especially Pentecostals and, more recently, undetermined evangelicals. It also coincides with the rise of the Nones, who, for the most part, like the undetermined evangelicals, maintain their spirituality without an institutional relationship. The difference is that the former maintain some identity with the evangelical principles, and the latter are disconnected from any religious institution — what Oliveira calls "religious disaffection," or aversion to churches or institutions. ${ }^{513}$ The decrease in Catholics and increase in evangelicals and non-religious people is most evident on the peripheries of metropolitan regions, in large urban centers, and on the occupation fronts in the northern center of Brazil. ${ }^{514}$

In his doctoral qualification research, Nicolini pointed out that the percentage of Nones in Brazil in 2012 was surprising, both in cities that make up metropolitan regions (such as Itanara in Bahia, with 33.33 percent Nones, and Porto Rico in Maranhão, with 31.95 percent) and in small cities in the extremities of the country (like Paranhos in Mato Grosso, with 33.91 percent, and Chuí in the Rio Grande do Sul, with 54.4 percent). ${ }^{515}$ This marked change in religious numbers

\footnotetext{
511 Alves, Barros, and Cavenaghi, “A dinâmica das filiações,” 152.

512 See Tables 1 and 2. See also Almeida and Monteiro, "Trânsito religioso no Brasil," 97.

${ }^{513}$ Oliveira, “A desafeição religiosa de jovens," 4.

514 Camurça, "O futuro das religiões no Brasil," 71.

515 Marcos Henrique de Oliveira Nicolini, “Religião e cidade: A precariedade dos ‘sem religião’ como contestação da exclusão social em São Paulo” (doctoral thesis, Universidade Metodista de São Paulo [UMESP],
} 2012). 
in Brazil has been seen as a change in the cultural paradigm that should have important implications for the coexistence of religions in the country. ${ }^{516}$

Given the growing and relatively new process of religious diversification in Brazil, interreligious dialogue, with an emphasis on flexibility and openness, ${ }^{517}$ has been a contemporary agenda in the country, aiming at "narrowing relations between religions that emerge from more diverse trunks," as opposed to ecumenism, which is restricted to approximation and joint action between different Christian religious manifestations. ${ }^{518}$

In this scenario of religious change, the Nones seem to be the most honest portrait of the changing and permanent nature of religion, reflecting the influences of postmodern forces such as individualism, relativism, and subjectivity. Portela describes Nones as engaged in an inner search and striving to develop self-identity and human potential. ${ }^{519}$ Luiz points out that they hold the spirit and soul of the individual in the gravitational center. ${ }^{520}$ Along with the country`s transformations, the Nones have also changed, not in the sense of abandoning religion, but in their way of exercising it. As part of human life, religiosity was maintained, but it came to be exercised in different forms. As Luiz clearly expressed, the moment one points to a breakdown of religion, it resurfaces in a multiplicity of forms and expressions, maintaining a posture of dialogue as it rearticulates with modernity. For him, public secularization brought a kind of

${ }^{516}$ Camurça, "O futuro das religiões no Brasil," 52-71.

${ }^{517}$ Wagner Lopes Sanchez, “(Des)encontro dos deuses: CNBB e pluralismo religioso no Brasil, um debate a partir dos Encontros Intereclesiais de Base de CEB's (1992-1997)" (doctoral thesis, Pontifícia Universidade Católica de São Paulo, 2001).

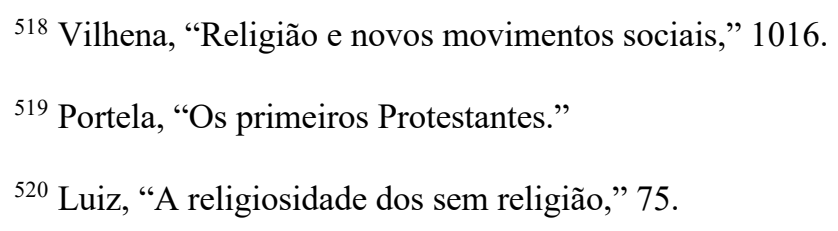


renewal of the sacred in the private sphere, providing a plurality of beliefs and a restructuring of the religious scene..$^{521}$

The scenario and context of Brazil changed, but the need for religion continued in a modernized and postmodernized reality. Strong emphasis on freedom of choice, individualization, democratization, and multiplication of religious offerings led people to break ties with Catholicism. New religious choices were made, with a tendency to weaken the borders of institutional belonging, raising the percentage of Nones in the country. ${ }^{522}$

Likewise, on the American side, the emergence of contemporary spirituality, contrasting with institutional and dogmatized religion, and involving 27 percent of Americans in general and 37 percent of Nones, is an example of a new manifestation of religiosity (see Table 11 and Figure 8). In his research with the baby boomer generation in America in the early 1990s, Roof was the first to describe the phenomenon of spirituality that was embraced by younger generations. Calling this group "a generation of seekers," Roof observed their search for a religiosity marked by free choice, culminating in a "tailor-made meaning system," or a personal spiritual lifestyle without institutional intervention and devoid of belonging. ${ }^{523}$

Giordan points out that the wave of contemporary spiritualization in force not only in American and Brazilian societies, but also beyond the limits of Christianity, is a kind of rediscovery of the body's function in the process of relating to the sacred. For him, the spiritual approach emphasizes the intimate, subjective, and personal aspect of religion, which involves the body, overcoming the dualistic juxtaposition of the soul and body. Besides, the body is seen as

\footnotetext{
${ }^{521}$ Luiz, “A religiosidade dos sem religião," 78.

522 Camurça, "O futuro das religiões no Brasil," 71.

${ }^{523}$ Roof, A Generation of Seekers, 310.
} 
the starting point for accessing the spiritual dimension of existence. In this perspective, contemporary spirituality unites body, soul, feelings, and sensations, including sexual experience, in spiritual terms, pointing to transcendence of the self and union with the energies of the universe. ${ }^{524}$

Wuthnow contrasts contemporary spirituality with traditional and institutionalized forms, using the term "dwelling spirituality" for the latter and "seeking spirituality" for the former. For him, dwelling spirituality is associated with temples, rites, dogmas, clear limits, and the presence of institutional authority. Seeking spirituality, on the other hand, is not associated with physical space, but with the diverse experiences of daily life, implying inclusion, hybridization, and the construction of a spiritual lifestyle based on an autonomous relationship with the sacred. Like Roof, Wuthnow believes that the religious and spiritual dimensions of the transcendent relationship are not mutually exclusive. ${ }^{525}$ However, other scholars maintain that religion and spirituality, as presented in contemporary times, are mutually incompatible, as their assumptions are based on opposite poles: external and internal, institutional and individual, objective and subjective, among others. ${ }^{526}$

Nonetheless, there is a growing trend of secularization among American Nones, which defies predictions of the permanent nature of religion. A comparative study between 2007 and 2014 shows an increase in the proportion of atheists and agnostics among the Nones, from 25 231.

${ }^{524}$ Giuseppe Giordan, “The Body between Religion and Spirituality,” Social Compass 56, no. 2 (2009):

525 See Wuthnow, After the Baby Boomers; Wade Clark Roof, Spiritual Marketplace: Baby Boomers and the Remarking of American Religion (Princeton, NJ: Princeton University Press, 1999).

${ }^{526}$ See Paul Heelas and Linda Woodhead, The Spiritual Revolution: Why Religion Is Giving Way to Spirituality (Oxford: Blackwell, 2007); Houtman and Aupers, "The Spiritual Turn"; Paul Heelas, "The Spiritual Revolution of Northern Europe: Personal Beliefs," Nordic Journal of Religion and Society 20, no. 1 (2007): 1-28. 
percent to 31 percent. Further, in 2007, 69 percent of the Nones said they believed in God or a universal spirit, but that dropped to 61 percent in 2014. Regarding the importance of religion, in 2007, 57.5 percent of Nones said that religion was not crucial for their lives, rising to 64.7 percent in 2014. In absolute numbers, that means a jump from 21 million to 36.1 million people who said they did not see religion as important to them. Likewise, there was a decrease in frequency of prayer: the proportion of Nones who said they never or seldom prayed went from 56 percent in 2007 to 62 percent in $2014 .^{527}$ The generational factor also confirms this trend toward increased secularization among the Nones. In America, Nones are most common in younger generations. For instance, in 2014, only 11 percent of the Silent Generation (born 19281945) declared themselves Nones, compared to 36 percent of younger millennials (born 19901996) (see Table 9), and studies show that younger Americans are less committed to religious beliefs and practices. ${ }^{528}$

\section{Table 12. Rapid Growth in Number of Religious "Nones" Who Say Religion Is Not Important to Them}

\begin{tabular}{|c|c|c|c|}
\hline & 2007 & 2014 & Change \\
\hline Number of adults in U.S. & $227.2 \mathrm{~m}$ & $244.8 \mathrm{~m}$ & $+17.6 \mathrm{~m}$ \\
\hline Share of adults who are religiously unaffiliated & $16.1 \%$ & $22.8 \%$ & +6.7 points \\
\hline NUMBER of religiously unaffiliated adults & $36.6 \mathrm{~m}$ & $55.8 \mathrm{~m}$ & $+19.2 \mathrm{~m}$ \\
\hline $\begin{array}{l}\text { Share of unaffiliated adults saying religion is } \\
\text { "not too/not at all" important in their lives }\end{array}$ & $57.5 \%$ & $64.7 \%$ & +7.2 points \\
\hline $\begin{array}{l}\text { NUMBER of religiously unaffiliated adults } \\
\text { saying religion is not important in their lives }\end{array}$ & 21.0m & $36.1 \mathrm{~m}$ & $+15.1 \mathrm{~m}$ \\
\hline \multicolumn{4}{|c|}{ Source: 2014 Religious Landscape Study, conducted June 4-Sept. 30, 2014.} \\
\hline PEW RESEARCH CENTER & & & \\
\hline
\end{tabular}

527 See Pew Research Center, "U.S. Public Becoming Less Religious”; Pew Research Center, "A Closer Look." See also Table 12.

${ }^{528}$ Pew Research Center, "U.S. Public Becoming Less Religious." 
American Nones are becoming more secular, and therefore the Durkheimian concept of the permanent and changing nature of religion seems to encounter resistance in their behavior. This group may never reach the point of complete secularization, but it is an increasing trend.

On the other hand, the declining value of religion is accompanied by an increasing appreciation of spirituality. In other words, there is a rejection of institutionalized religion, but not religiosity itself. When Nones were asked about deep feelings of spiritual peace and wellbeing, the number who said they regularly experienced them increased from 35 percent to 40 percent between 2007 and 2014. Additionally, 47 percent of Nones in 2014 shared profound feelings of admiration for the universe, compared to 39 percent in $2007 .{ }^{529}$ These studies confirm what other research has already shown about the 37 percent of American Nones who claim to be spiritual but not religious. They are moving away from institutionalized religion to embrace independent, syncretic, metaphysical, and diluted theological content. ${ }^{530}$ In this perspective, Durkheim`s theory about the permanent and changing nature of religion is an experience lived by at least that portion of the American Nones. Religion changes in form, but it remains essential in the construction of the meaning of life.

\section{Summary of Category 4}

The permanent and changing nature of religion theorized by Durkheim and some of his disciples can be confirmed by the experience of the Nones in America and Brazil. On the

${ }^{529}$ Pew Research Center, "U.S. Public Becoming Less Religious.”

${ }^{530}$ See Pew Research Center, "More Americans Now Say"; Williams B. Parsons, ed., Being Spiritual but Not Religious: Past, Present, Future (New York: Routledge, 2018); Miller, "Spiritual but Not Religious," 833-94; Heelas and Woodhead, The Spiritual Revolution; Heehs, Spirituality without God; Fuller, Spiritual, but Not Religious. 
Brazilian side, the religious movement from Catholic to traditional evangelical, Pentecostal, Neopentecostal, undetermined evangelical, and finally None is evidence that the majority of the population maintains religiosity at the center of life, given that less than 5 percent of the Nones are atheists or agnostics. Only the way of expressing it has changed, following the country`s social transformations. The population maintains its belief in the transcendent and practices religiosity without institutional associations and with syncretic, subjective, and particular characteristics.

On the American side, albeit to a lesser extent, religious switching between denominations and the fact that the majority expresses belief in God support the permanent and changing nature of religion. Perhaps the most significant evidence in favor of the theory is the behavior of the 37 percent of American Nones who declare themselves to be "spiritual, but not religious," meaning a break with religious dogma linked to institutions in favor of a metaphysical and particularized religiosity, like that of most Brazilian Nones. However, the small trend of increasing secularism among American Nones is a challenge to the permanent nature of religion advocated by the Durkheimian school. If this behavior has a ceiling, or if it can reach the majority group, only more accurate research and time will show.

\section{Category 5: The Contemporary Secular}

Summary of the Topic

Defending the idea that secularization is not essential to modernity, or that modernity does not require religious emancipation, Asad presents what he calls "the contemporary secular," someone who supports both modern values and principles of faith at the same time. For him, contemporary religion can retain faith and moral principles together with the core values of modernism, such as individual freedom of expression and choice, public support for science, 
respect for differences, and other modern policies related to education, the economy, and life in society. ${ }^{531}$ Davie expresses a similar thought in pointing out that religion will never disappear in favor of a wholly secularized society. For her, some religious beliefs are likely to continue to accompany people's more secular understandings of life. ${ }^{532}$ Luckmann corroborates these views by demonstrating that people are encouraged to exercise autonomy in the contemporary context, building their own identity through free choice as consumers, when dealing with both culture and the sacred cosmos. The product of this exercise of autonomy is the construction of a human being who absorbs religious principles and, at the same time, is aligned with modern society. ${ }^{533}$

\section{Relating the Topic to the Nones in Brazil and the United States}

In contemporary times, the religious panorama of Brazil has been described as a mixture of secularization in the juridical-state sphere, religious freedom in the individual plane, and religious movement in the cultural plane. ${ }^{534}$ Camurça calls this phenomenon postmodern syncretism, in which there is a combination of modern trends, such as the primacy of the individual, free choice, and religious pluralism, with pre-modern trends, such as holism, mysticism, and religiosity. ${ }^{535}$ The result is a framework of modernization, liberalization, and

\footnotetext{
State, Secularism."

${ }^{532}$ Davie, Sociology of Religion, 98, 140.

${ }^{533}$ Luckmann, The Invisible Religion, 97-103.

${ }^{534}$ Antônio Flavio Pierucci, “De olho na modernidade religiosa," Tempo Social 2, no. 20 (2008): 15.

${ }^{535}$ Camurça, "O futuro das religiões no Brasil," 74.
} 
democratization operating in the country, ${ }^{536}$ and a religious expression that denotes a modernization of habits together with a subjective and individualized religiosity. ${ }^{537}$

The Nones in Brazil synthesize this religious expression that unites religiosity with modern principles in daily practice. There has been an increase in marriages without legalization, a decrease in birth rates, and an increase in schooling, prioritizing individual choices, and other modern habits, along with the search for subjective religiosity. ${ }^{538}$ The Brazilian Nones are modern, urban, young, and located in the middle or the rising classes; most of them maintain an intrinsic religiosity separate from institutions. ${ }^{539}$ This is very close to the description of the secular contemporary by Asad and other scholars, as someone who inhabits modernity while maintaining religion on a subjective basis.

The same is true on the American side. In her work on the meaning of "non-religion," especially in the American context, Lee paints a picture very close to the secular contemporary described by Asad. According to Lee, "non-religion" does not necessarily denote an absence of religiosity, but a separation from institutionalized religion. In this case, the term brings together a combination of religious, spiritual, and secular characteristics, denoting someone who incorporates the secular concepts of freedom and individuality without giving up spiritual

\footnotetext{
${ }^{536}$ Camurça, "O futuro das religiões no Brasil,” 75.

537 Antoniazzi, “As religiões no Brasil," 87.

538 Antoniazzi, “As religiões no Brasil," 87.

${ }^{539}$ Marcelo Camurça, “O Brasil religioso que emerge do censo 2010: Consolidações, tendências e perplexidades," in Religiões em movimento: o censo de 2010, ed. Faustino Teixeira and Renata Menezes (Petrópolis: Vozes, 2012); Novaes, “Os jovens sem religião," 321-30.
} 
practices lived in a private context. Lee points out that "anti-clerical protest," "secular humanist," and "spiritual but not religious" are some of the varied forms of contemporary non-religion. ${ }^{540}$ Fuller points out that the contemporary unchurched seek to fulfill the assumptions of American culture related to moral responsibility, which presupposes free will, but without giving up the intervention of supernatural powers. For him, this group is mirrored in the American middle class of the nineteenth century, who, feeling suffocated by the rigidity of the churches, energetically sought ways to accommodate their religious impulses to the values of the modern world. For Fuller, the highly active seekers of that time were the vanguard of what would become the long American tradition of piety without church; those who claim to be spiritual without religion seek to maintain their dependence on the supernatural, without institutional intervention, while preserving contemporary liberal values. ${ }^{541}$

\section{Summary of Category 5}

Asad`s secular contemporary, which can also be seen in Davis and Luckmann`s descriptions, is reflected in the Brazilian and American Nones. They maintain spiritual beliefs, especially on a subjective and intrinsic level, and at the same time, incorporate modern and secular practices, in an exercise of autonomy. The secular contemporary is the figure of a human being aligned with modern habits of freedom, independence, relativism, syncretism, and acceptance of differences, while maintaining a subjective and individualized religiosity. In both cultures, for example, the Nones are the group that most often marry people of other faiths,

\footnotetext{
${ }^{540}$ Lois Lee, "Non-Religion," in The Oxford Handbook: The Study of Religion, ed. Michael Stausberg and Steven Engler (Oxford: Oxford University Press, 2016), 84-86.

${ }^{541}$ Fuller, Spiritual, but Not Religious, 43-44.
} 
maintain consensual marriages without legal ties, and defend a liberal policy that allows abortion and same-sex marriage. ${ }^{542}$

\title{
Category 6: Influence of Technological Advances and Mass Communication
}

\author{
Summary of the Topic
}

Although the researched authors did not delve deeper into the influence of technological advances and mass communication on contemporary religiosity, they provide a glimpse of the importance of this topic. In their studies of recruitment theories, Stark and Bainbridge concluded that networks are the number one effective recruitment tool for cults, sects, and conventional religions, as well as for preventing desertions. They stated that interpersonal ties are far more effective than ideologies themselves in sustaining commitments. They also emphasized that the reward system is fundamental to the recruitment process through networking. People are attracted when their needs are met and their deprivation reduced, whether in the affective, physical, emotional, or spiritual realms. ${ }^{543}$ Stark and Bainbridge concluded that "social networks are direct rewards." 544 On the other hand, Luckmann maintains that the diffusion of urban culture through mass media is one of the factors that generate religious disinterest and secularization. ${ }^{545}$ Bryan Wilson points out that technology has undermined the past near-monopoly of churchowned communication. The church, which once represented a powerful voice in the local community, became just one more voice among many different religious messages and then

\footnotetext{
542 See Pew Research Center, "Religious Landscape Study: Adults Who Believe”; Rodrigues, “Os sem religião"; Vilhena, "Religião e novos movimentos sociais"; Mariano, "Efeitos da secularizaçao do estado."

543 Stark and Bainbridge, "Networks of Faith," 1392-93.

544 Stark and Bainbridge, "Networks of Faith," 1394.

${ }^{545}$ Luckmann, The Invisible Religion, 29-30.
} 
competed with increasingly efficient voices that, through mass communication technologies, began to offer non-religious distractions. ${ }^{546}$ Berger points out that literature and mass communication allow access to people's beliefs and values everywhere, facilitating religious pluralism, creating an enabling environment for people from different backgrounds to live together with a spirit of tolerance. For him, this pluralist tendency strengthened by mass communication is a challenge for institutions with absolute truth claims. ${ }^{547}$

\section{Relating the Topic to the Nones in Brazil and the United States}

Scholars see a direct connection between migratory growth, technological advancement, and the expansion of religious diversity in America. For them, the movement of people from different cultures, together with the globalization of information, provided broad exposure to diverse religions, beliefs, and practices that were absorbed by society. ${ }^{548}$

There is a very close relationship between the origins of radio broadcasting and religion in both the United States and Brazil. On December 24, 1906, Canadian American inventor Reginald A. Fessenden conducted the first experimental AM radio broadcast in Massachusetts, which included reading texts about the birth of Jesus from the Gospel of Luke, along with a violin solo of "O Holy Night," and songs by Handel (Largo). ${ }^{549}$ In Brazil, many consider the

\footnotetext{
546 Wilson, “Aspects of Secularization,” 49.

${ }^{547}$ Berger, Questions of Faith, 14-15. See also Cox, The Secular City, xxxv, xxxvii-xxxix.

548 See Roof, Spiritual Marketplace, 61, 70-73; Rebecca French, "Shopping for Religion: The Change in Everyday Religious Practice and Its Importance to the Law,” Buffalo Law Review 127 (2003): 133-36.
}

${ }^{549}$ Leonildo Silveira Campos, "Evangélicos, Pentecostais e carismáticos na mídia radiofônica e televisiva," Revista USP, no. 61 (March/May 2004): 151; Jeremy Normans, "Reginald Fessenden Conducts the First Audio Radio Broadcast of Entertainment and Music," Historyofinformation.com (blog), accessed April 4, 2020, http://www.historyofinformation.com/detail.php?entryid=1639. 
gaucho priest Roberto Landell de Moura, trained in theology, physics, and chemistry in Rome, to be the father of Brazilian radio. ${ }^{550}$

In the early years, radio content was mainly music and various messages, which changed from 1920 onwards with the appearance of commercial radio stations and space for religious programs. That year, Dr. Frank Conrad started the first commercial radio broadcast in Pittsburgh, with the prefix KDKA. Two months later, the Calvary Episcopal Church started broadcasting its religious activities. A year after that, the Washington National Presbyterian Church founded its station, followed by missionary Aimee McPherson in 1924. In the beginning, churches generally broadcast their worship services over the radio. In 1925, 10 percent of the 600 commercial radio stations operating in the United States were linked to religious movements. ${ }^{551}$

In the 1960s, the concept of "electronic church" emerged. In the American context, this expression applies to the use of mass media, especially television, for the transmission of religious content, almost always in a personalized way and relatively independent of conventional Christian denominations, by so-called "televangelists." 552 Rex Humbard is considered the first television evangelist in the United States; his radio and TV programs began airing in 1949 at the CBS branch in the city of Indianapolis, and spread worldwide. ${ }^{553}$ Billy

${ }^{550}$ Fabio S. Flosi, "Father Landell de Moura-Radio Broadcasting Pioneer," Philatelia Chimica et Physica 34, no. 1 (2012): 18-26; Edward A. Riedinger, "Landell de Moura, Father Roberto 1861-1928 Brazilian Wireless Pioneer," in Encyclopedia of Radio (2003), 1696; Luciano Klockner and Manolo Silveiro Cachafeiro, eds., Por que o Pe. Roberto Landell de Moura foi inovador? Conhecimento, fé e Ciência (Porto Alegre, RS: Edipucrs, 2012); Maurício Tuffani, "O verdadeiro inventor do radio," Unespciência, November 2010, 50, https://www.unesp.br/aci/revista/ed14/ponto-critico.

${ }^{551}$ José Ozean Gomes, “Diversidade religiosa e mídia radiofônica: O uso das rádios comunitárias por instituições evangélicas no Brasil," 2020 Azusa-Revista de Estudos Pentecostais 4, no. 2 (2013): 190; Campos, "Evangélicos, Pentecostais e carismáticos," 151. Vozes, 1986).

${ }^{552}$ Hugo Assman, A igreja eletrônica e seu impacto na América Latina: Convite a um estudo (Petrópolis:

553 The Rex Humbard Foundation, http://www.rexhumbard.org. 
Graham was another pioneering televangelist, having started his activities in 1951 and his international evangelistic crusades in 1954. That same year, Oral Roberts also started to present programs on TV, after using the radio since 1947 as mass communication for his preaching, based on "faith healing." 554 Other prominent North American television evangelists include Robert Schuller, Pat Robertson, Jimmy Swaggart, and James Bakker. The latter two were involved in financial and sexual scandals. ${ }^{555}$ The literature highlights the extreme verbal and visual communication techniques practiced by American televangelists aiming at fundraising. ${ }^{556}$ Mass media transmission of religious content in Brazil dates back to the 1940s. The Seventh-day Adventist Church was a pioneer in this process. The Voice of Prophecy, presented by Pr. Roberto Rabelo, together with music by the quartet the King Heralds, was the first Brazilian radio program with religious content, starting on September 23, 1943, and broadcast by seventeen radio stations in its historical version. ${ }^{57}$ It was a version of the American program led by Pr. HMS Richards, who started broadcasting a series of biblical themes on KNX radio in Los Angeles on October 19, 1929, despite criticism from those who thought that radio was a profane means of preaching. In 1937 the program was renamed The Voice of Prophecy, and broadcast on a network by different radio stations in several American states. ${ }^{558}$ Another prominent religious

\footnotetext{
${ }^{554}$ Campos, "Evangélicos, Pentecostais e carismáticos,” 157.

${ }^{555}$ Campos, "Evangélicos, Pentecostais e carismáticos,” 158.

${ }^{556}$ Assman, A igreja eletrônica, 54; William F. Fore, "The Electronic Church,” Ministry, January 1979, 5;
} Peter G. Horsfield, Religious Television: The American Experience (New York: Longman, 1984); Ben Armstrong, The Electric Church (Nashville, TN: Thomas Nelson, 1979).

${ }^{557}$ Jolivê R. Chaves, "Evangelismo integrado na Divisão Sul Americana da Igreja Adventista do Sétimo Dia: Uma descrição" (doctoral thesis, UNASP, 2014), 173; Nair Prata, Debora Cristina Lopez, and Wanir Campelo, "Panorama do rádio religioso no Brasil," Intercom, accessed April 23, 2010, http://www.intercom.org.br/papers/nacionais/2014/resumos/R9-0548-1.pdf.

${ }^{558}$ Voice of Prophecy, "About the Voice of Prophecy—Equipping the World for Christ to Come," accessed April 23, 2020, https://www.voiceofprophecy.com/about. See also Eldyn Karr, "Voice of Prophecy, Historic Adventist Media Outreach, Relocating to Colorado," Adventist Review, January 7, 2014, 
program on the Brazilian radio scene first aired on November 30, 1953, under the leadership of Presbyterian Pr. José Borges dos Santos Jr. Entitled Morning Meditation, the program was broadcast on Tupi Radio in São Paulo, later going to Bandeirantes Radio. ${ }^{559}$

In the 1950s, the "divine healing" movement already present on North American radio stations arrived in Brazil through the National Evangelization Crusade. Pentecostal crusades were held in canvas tents and used the radio for support and dissemination. In this process, Manoel de Mello founded the church “O Brasil para Cristo," and Davi Martins Miranda founded the church "Deus é Amor," emphasizing divine healing. ${ }^{560}$ From the 1960s on, Catholics, Adventists, and representatives of Pentecostal churches began to share space in radio grants in the national territory. ${ }^{561}$

Adventists were also pioneers on television: in 1962, Pr. Alcides Campolongo started Faith for Today, the first religious program on Brazilian television. ${ }^{562}$ In 1978, the Brazilian media started selling space to televangelists from the United States, especially Rex Humbard, Jimmy Swaggart, and Pat Robertson. The program model developed by Robertson, combining preaching, an emphasis on miracles and wonders, and the pursuit of health and prosperity through faith, would later influence Brazilian media evangelists. ${ }^{563}$

https:/www.adventistreview.org/church-news/voice-of-prophecy,-historic-adventist-media-outreach,-relocating-tocolorado.

${ }^{559}$ Prata, Lopez, and Campelo, "Panorama do rádio religioso no Brasil," 3.

${ }^{560}$ Gomes, “Diversidade religiosa e mídia radiofônica,” 192-93.

${ }^{561}$ Suzy dos Santos and Sérgio Capparelli, “Crescei e multiplicai-vos: A explosão religiosa na televisão Brasileira," Intexto 2, no. 11 (2004): 3.

${ }^{562}$ Chaves, "Evangelismo integrado," 173; Luther King de Andrade Santana, "Religião e mercado: A mídia empresarial-religiosa," REVER, no. 1 (2005): 56-57.

563 Campos, “Evangélicos, Pentecostais e carismáticos,” 159. 
In the 1990s, with the advancement of Neopentecostalism ${ }^{564}$ in Brazil, an accelerated process of competition over television channel concessions and radio stations for religious purposes began, especially among Catholic and Neopentecostal churches, changing the traditional forms of evangelistic transmission in Protestantism and Catholic masses to a format more connected with religious market pluralism. The concept of "electronic church," present in the United States since the 1960s, was transported to Brazilian territory, initiating a symbolic battle for the faithful through the media, making mass communication the primary tool for attracting new members. ${ }^{565}$

The establishment of the electronic church in Brazil accelerated religious pluralism and the assimilation of modern and postmodern characteristics in the country`s religiosity. "Religious marketing" or "marketing of faith" is one of these characteristics: potential members are seen as consumers of religious products that must be won over by marketing strategies. Phrases like "electronic pastors" and "commercial religion," in addition to "faith marketing" and "electronic church," come to designate the new phenomenon of religious communication in the country by radio and television. In this context, the central factor is the use of a more aggressive advertising model to win new followers for congregations. ${ }^{566}$

\footnotetext{
${ }^{564}$ Neopentecostalism was established in Brazil in the 1970s and 1980s. It is considered the Pentecostal "third wave" in the country, and places particular emphasis on spiritual war against the devil, the theology of prosperity, and the liberation of customs. "Classic Pentecostalism," which emphasizes the gift of languages and ascetic withdrawal from the world, is called the "first wave." It was brought to Brazil by American missionaries in 1910 and 1911 with the foundation of the Churches Congregation Christian of Brazil and the Assembly of God, respectively. In the 1950s, "divine healing Pentecostalism," called the "second wave," established itself with the founding of the Foursquare Evangelical Church in 1951 and the Brazil for Christ Church in 1955. See André Ricardo de Souza, Igreja in concert: Padres cantores, mídia e marketing (São Paulo: Annablume: Fapesp, 2005), 16.

${ }^{565}$ Prata, Lopez, and Campelo, "Panorama do rádio religioso no Brasil," 4; Arlindo Pereira Dias, Domingão do Cristão: estratégias de comunicação da Igreja Católica (São Paulo: Salesiana, 2001).

${ }^{566}$ Assman, A igreja eletrônica.
} 
In this process, as Berger says, religion is no longer seen as something to be imposed, but commercialized, and the question of the result becomes essential. The minister's profile changes, he says, taking on a socio-psychological aspect, with an activist and pragmatic orientation, as well as high interpersonal skills. In the same way, religious content becomes "fashion," that is, based on the preferences and feelings of the target audience. Religious products are prepared following consumer pressure, and religion is no longer a reference to the cosmos or history, but to individual existence or psychology, legitimized on an empirical basis and no longer on a cognitive content basis. Then, there is the so-called socio-psychological phenomenon of the demonopolization of faith, in which, instead of discovering religion through a religious institution or biblical research, people resort to subjective conscience to find it. ${ }^{567}$

In Brazil today, radio, TV, and social networks have been the leading platforms for the expansion of Neopentecostal churches. The media highlight figures such as Edir Macedo from the Universal Church of the Kingdom of God, Valdemir Santiago from the World Church of the Power of God, Silas Malafaia from the Assembly of God-Victory in Christ, RR Soares of International Church of the Grace of God, and Estevam Hernandes Filho and his wife Sonia of the Reborn in Christ Church. ${ }^{568}$ Brazilian televangelists have expanded on their North American

\footnotetext{
${ }^{567}$ Berger, The Sacred Canopy, 270-77.
}

${ }^{568}$ Antunes describes the emphasis on "theology of prosperity" as a sturdy base for the preaching of Neopentecostal churches in the country. For him, one of the leading causes for the growth of this evangelical branch in Brazil is the idea that material progress results, in some way, from the favor of God. He points out that traditional Catholic preaching with "a very conservative look to an afterlife instead of earthly riches" has been a significant cause of the unrestrained loss of members to Neopentecostal denominations. Antunes describes these churches as highly profitable businesses in Brazil, bringing their leaders wealth and a life of ostentation. His list of the wealthiest pastors in Brazil includes Edir Macedo from the Universal Church of the Kingdom of God ( $\$ 950$ million), Valdemir Santiago from the World Church of the Power of God (\$220 million), Silas Malafaia from Assembly of God-Victory in Christ (\$150 million), RR Soares of International Church of the Grace of God (\$125 million), and Estevam Hernandes Filho and his wife Sonia of the Reborn in Christ Church ( $\$ 65$ million). See Anderson Antunes, "The Richest Pastors in Brazil,” Forbes.com, January 17, 2013, https://www.forbes.com/sites/andersonantunes/2013/01/17/the-richest-pastors-in-brazil/\#22c335ab5b1e. 
colleagues` methodology established in the salvation-miracles-collection axis. Starting from this platform, they add an emphasis on preaching economic-financial prosperity as a sign of God`s blessing, and associate human problems such as depression, family crises, and drugs with the work of spirits. ${ }^{569}$

Catholic Charismatic Renewal (CCR), founded in the United States in 1967, arrived in Brazil at the end of that decade, and in the 1990s, it was revived to face the church's loss of members, especially the loss to Neopentecostalism. Combining Catholic tradition, charismatic elements, and ideas associated with market religiosity, which is typical of pluralism, the CCR repopularized Catholicism in the country, especially among younger generations. CCR mixes a psychological perspective, in which problems are attributed to personal weaknesses, with a view of demonic action in people's daily activities. Repetitive formulas of prayer, interpreted by scholars as an element of self-help, plus the addition of divine blessing, are used. A strong emphasis is placed on the grace of God, experience with the Holy Spirit, prayer as a fight against demonic actions, and gospel-style music using emotional lyrics, according to the Pentecostal and Neopentecostal standard. Nevertheless, perhaps the most striking element of CCR in Brazil has been its use of the media and religious marketing to expand and retain members. The church uses market themes, a strong media presence, masses in the form of concerts, and singing priests, seen as pop stars and as a product launched in the religious market. ${ }^{570}$

${ }^{569}$ Magali do Nascimento Cunha, “O conceito de religiosidade midiática como atualização do conceito de Igreja Eletrônica em tempos de cultura 'gospel'" (paper presented at the 25th Brazilian Congress of Science of Communication, Salvador, BA, September 4-5, 2002), http://intercom.org.br/papers/nacionais/2002/Congresso2002_Anais/2002_NP1cunha.pdf.

570 See Souza, Igreja in concert, 13-20; Sílvia Regina Alves Fernandes, "Review of Igreja in concert: padres cantores, mídia e marketing by André Ricardo de Souza, Centro de Estatística Religiosa e Investigações Sociais - Brasil," Horizontes Antropológicos 12, no. 25 (January/June 2006): 311-15; Sílvia Regina Alves Fernandes, "Renovação carismática e o demônio: Notas do monitoramento da Revista Jesus Vive e é o Senhor," Mneme-Revista de Humanidades 3, no. 6 (2002): 7-8; Cecília Mariz, "Católicos da libertação, Católicos renovados e Neopentecostais_-estudo de caso no Rio de Janeiro," Cadernos CERIS 1, no. 2 (2001): 17-42. 
Campos synthesizes the pluralistic Brazilian religious reality through the media, associating religion with commerce and describing the worldview as a large shopping center in which temples, markets, religion, and entertainment are merged. The result is the delivery of a broad symbolic menu to religious consumers, who can assemble it to their taste, regardless of tradition..$^{571}$

The National Film Agency (ANCINE) indicates that 21 percent of all television programming broadcast in Brazil in 2015 was religious. ${ }^{572}$ In a more comprehensive view, including radio, broadcast and pay TV, print media, and social networks, a survey by Media Ownership Monitor Brazil points out that of the fifty vehicles with the greatest audience or public influence in Brazil, at least nine are controlled by Christian, Catholic, or evangelical religious leaders. ${ }^{573}$ Along with the use of $\mathrm{TV}$ and radio as a platform for religious marketing, these media and the churches they represent have served as an electoral stage for pastors and other politicians linked to religious groups. ${ }^{574}$ In the United States, there are 2,400 radio stations and one hundred TV stations categorized as Christian, of which 80 percent are considered nonprofit or non-commercial. Non-commercial radio stations that have a religious format account for 42 percent. ${ }^{575}$

\footnotetext{
${ }^{571}$ Campos, "Evangélicos, Pentecostais e carismáticos," 163.

${ }^{572}$ Agência Nacional do Cinema, "ANCINE divulga informe sobre programação na TV aberta do ano de 2015," June 17, 2016, https://www.ancine.gov.br/pt-br/sala-imprensa/noticias/ancine-divulga-informe-sobreprograma-o-da-tv-aberta.

573 "Brazilian Churches as Media Owners," Media Ownership Monitor Brasil, Repórteres sem Fronteiras e Intervozes, accessed April 5, 2020, https://brazil.mom-rsf.org.

${ }^{574}$ Gomes, “Diversidade religiosa e mídia radiofônica," 187-91.

575 “Religious Broadcasting," accessed November 17, 2020, https://transition.fcc.gov/osp/inc-report/INoC11-Religious-Broadcasting.pdf.
} 
In the two countries under study, the business of religious media is the result of an environment of pluralism and a market society where religion has lost its role in defining people`s daily lives. Especially in the Brazilian Neopentecostal context, it has produced a visible accumulation of goods and power by religious leaders. The mass media has become not only the main instrument for membership and denominational expansion, but also a platform for economic and political ascension, with churches' emphasis on the prosperity gospel. ${ }^{576}$ This Brazilian Neopentecostal version of prosperity through faith reflects what Weber defends as the Protestant ethic and the spirit of capitalism, according to which financial prosperity is not only legitimate for Christians but an outward sign of the grace of God. ${ }^{577}$

As for the reach of religious mass media in the United States, according to the Pew Research Center, in 2014, 23 percent of Americans in general, 32 percent of Protestants, 21 percent of Catholics, and 7 percent of Nones reported having watched a religious program on TV the week before. As for radio, 20 percent of Americans in general had listened to a religious program in the previous week, compared to 28 percent of Protestants, 15 percent of Catholics, and 8 percent of Nones. Regarding the use of social media to share faith, 20 percent of Americans in general said they had shared their faith online, while 40 percent said they did it offline, in a real-life situation. Among Protestants, 27 percent said they shared their faith online and 45 percent offline. Among Catholics, 15 percent shared their faith online and 38 percent offline. ${ }^{578}$ This shows that Protestants are the most reached by religious radio and TV in America, while the Nones are the least reached by these means of religious mass communication.

\footnotetext{
576 Santana, "Religião e mercado," 67.

${ }^{577}$ Weber, The Protestant Ethic, 105-12.

${ }^{578}$ Pew Research Center, "Religion in Electronic Media: One-in-Five Americans Share Their Faith Online," November 6, 2014, https://www.pewforum.org/2014/11/06/religion-and-electronic-media/.
} 
In general, all groups shared their faith more effectively in real-life situations than through social media, but the most significant difference was seen among the Nones, who shared almost three times more offline than online.

\section{Summary of Category 6}

The mass media have been effective instruments for religious propagation in both cultures, in a religious marketing process typical of pluralism. Although some of the Nones benefit from religious products widely accessible through the media, another part of the group, in both cultures, perceives churches as using mass communication to compete for members, spread quackery, seek political power, and promote the accumulation of wealth by religious leaders. In this case, mass religious communication has been an incentive for Nones to criticize religious institutions and their leaders and to seek their removal. In America, the Nones are the group that least often uses mass communication to spread their beliefs.

\section{Summary}

According to the studies presented in this chapter, religious disenchantment, as described by Weber and some of his disciples, affects the Nones in both Brazil and the United States more than the general population-whether it is applied to the secularization aspect of legislation or to the aspect of consciousness. However, this conclusion is not absolute, because due to the diversification of the Nones in both cultures, a majority of the group continues to believe in God and practice a personal, subjective, eclectic, and deinstitutionalized spirituality. In general terms, the data show that Brazilian Nones are less affected by disenchantment in the realm of consciousness than American Nones, who have more significant evidence of secularization.

The data also show that the Nones of both cultures defend the privatization of religiosity. For them, the state and religion must be kept separate, with the state responsible for social 
policies through secular legislation, and religion being confined to the private and individual level. Most of the group believes even religious institutions should not be responsible for religion, accusing them of manipulation and political and financial misconduct. In this context, there is a deviation of the center of power from religious institutions to religious subjects, as well as a weakening of the public and institutional influence of religion. However, there is also evidence that the Nones attach a particular social value to religion, and tend to sympathize with religious institutions that promote people`s social well-being.

Democratic ideas and religious freedom in both countries under study have deepened the roots of religious pluralism in both cultures. Religious marketing and religious spiritualization are two essential elements of this pluralism, resulting in the multiplication of religious servicesChristian and non-Christian — as well as religious relativism and the weakening of the content of the faith. There is also a dilution of institutional boundaries and strengthening of a syncretic, ecumenical religiosity guided by personal choices, in which each client creates a spiritual menu according to personal conveniences. In contrast to institutional religion, the wave of contemporary spiritualization, whose foundations were laid by spiritualism in the nineteenth century, is being driven by modernist and postmodernist proposals.

The group that identifies as "spiritual, but not religious" (SBNR), which represents 37 percent of American Nones and the majority of Brazilian Nones, is a product of this movement. It has also been proven that religious pluralism increases religious competition, reduces commitment to a particular and institutional religion, weakens religious identity, and simultaneously increases intrinsic religiosity, or search for spirituality. In this sense, religious pluralism increases religious disaffiliation. It contributes to the growth of the Nones in Brazil and 
the United States, generating a share of secularized Nones — atheists, agnostics, and indifferentand increasing the number of spiritual, but not religious Nones.

The study also proves the permanent and changeable nature of religion, advocated by Durkheim and some of his disciples. The two countries' social transformations and religious pluralism have generated a tremendous movement away from traditional denominations toward evangelical Pentecostal, Neopentecostal, and independent evangelical churches, culminating in the increase of the Nones. Most Nones continue to maintain belief in God or a cosmic entity, but begin to manage their religiosity in an independent way and without institutional associations. The majority of the population, therefore, retain their religiosity, but have changed their way of expressing it. However, there is a small tendency to increased secularization among the American Nones, which challenges the permanent nature of religion proposed by the from Durkheimian school. If this trend is permanent and will reach most people, only time will tell. Perhaps the so-called "secular contemporary" described by Asad, which finds echoes in Davis and Luckmann`s works, is the most appropriate image to describe most of the Nones in Brazilian and American societies today. It is the figure of someone who has assimilated the principles of modern and postmodern society — freedom, individuality, relativism, syncretism, and acceptance of differences, among others - while maintaining spiritual values based on a subjective and metaphysical religiosity.

Finally, the mass media have been useful for the spread of religion in both cultures, especially in the context of current religious marketing. While some Nones benefit from the broad religious products provided by the mass media, others believe religious institutions use the media to compete for members, spread quackery, seek political power, and enrich their leaders. 
The data also show that among American religious groups, the Nones least often use mass communication to spread their beliefs.

The next chapter will present some cultural and missiological implications for work with the Nones, based on the studies and discoveries hitherto undertaken. 


\section{CHAPTER IV}

\section{BIBLICAL FRAMEWORK FOR MISSION AMONG NONES}

\section{Introduction}

The current chapter presents a suggestive biblical framework for mission work among the Nones based on two biblical narratives from the Old Testament (OT) and two from the New Testament (NT). In the absence of a direct biblical text related to the Nones, as they are a phenomenon much later than the biblical period, narratives were chosen whose characters show certain similarities with some representations of the Nones. It is necessary to consider that the Nones are not a uniform group, but composed of different subgroups, as seen in the previous chapters. In this sense, the narrative of Naomi and Ruth (book of Ruth) and the narrative of Naaman's healing and conversion (2 Kgs 5:1-19) were chosen to lay a foundation for the interfaith relationship. Just as Naomi and Ruth's worldviews and the worldviews of Naaman and Elisha were quite distinct from the Jews worldview, given the religious and cultural differences involved, the worldview of the Nones is distinct from that of biblical Christians due to the different perspectives and assumptions that surround them. Thus, Ruth and Naaman's worldview transformation can provide insights for a compelling mission to the Nones.

In the NT, the narrative of the conversion of Cornelius and his relatives and close friends, called by Luke God-fearers or God-worshipers (Acts 10), sheds light on the mission among the large portion of the Nones who are defined as seekers, or spiritual and not religious. These groups are similar in their openness to the spiritual, and need to know the biblical God in his 
uniqueness and as a personal being. The second narrative, involving Paul's speech in Athens to the philosophers (Acts 17), opens up a perspective for the mission among other groups of Nones, especially those who declare themselves to be atheists and agnostics.

In these four narratives, the characters involved are foreigners, whose conversion is the work of God and his human representatives. Narratives of conversion of foreigners can present missiological principles appropriate to work with the Nones today. As Naaman and Ruth's worldview in the OT and the worldview of Cornelius and the Athenian philosophers in the NT was very different from the worldview of the Jews and Christians, likewise today, the Nones' worldview is very different from the worldview of contemporary biblical Christians. This means that Brazilian and American Christians need to think that the Nones in both cultures are like foreigners because their worldview is different. Mission among Nones is thus like a crosscultural endeavor. The cross-cultural mission carried out in each story evokes principles applicable to cross-cultural work with contemporary Nones. Based on the narratives, four missiological biblical principles were chosen:

1. Mission based on relationships or the hesed attitude

2. Mission based on the saving power of God

3. Mission based on biblical instruction

4. Mission based on contextualization

\section{Principle 1: Mission Based on Relationships- An Action of $\boldsymbol{H e s e d}$}

The propensity for relationship has been pointed out as an aspect of God's image in humanity ${ }^{579}$ In other words, created in the image of the God of creation (Elohim), who lives in

${ }^{579}$ As Souza states, "The biblical God in his self-revelation, in the Old Testament, acts and is expressed in a plurality of persons." Elias Brasil de Souza, "Fundamentos bíblicos e teológicos do ministério de pequenos grupos," 
intradivine interaction, humans have in our nature the need to relate. ${ }^{580}$ From a spiritual perspective, the relationship between humans and God was broken with the entrance of sin, but God took the initiative to reconcile by meeting humans (Gen 3:8-10, 15). Missio Dei is not only God reconciling the world to himself through Christ, but also the foundation for the church's mission, which according to Paul, is the ministry of reconciliation (2 Cor 5:19). ${ }^{581}$ From this perspective, John says that he who announces the gospel invites people to an experience of koinonia - communion with God, with Christ, and with those who are part of the body of Christ, his church (1 John 1:3), designating evangelization as an instrument for restoring and deepening relationships in the vertical and horizontal sense. ${ }^{582}$

Tompkins follows this same reasoning when he defends the hesed attitude, as it appears in the narrative of Ruth, as a foundation for mission because it becomes the basis for restoring relationships, especially in the cross-cultural context. In the book of Ruth, the hesed attitude is part of the relationship between Naomi, a believer in Yahweh, the God of Israel, and Ruth, a Moabite whose people worship the idol Chemosh. ${ }^{583}$

in Pequenos grupos, grandes soluções, ed. Milton Torres (Guarulhos, SP: Parma, 2007), 16. Hasel explains that the Hebrew term for God in the creation account (Elohim) is a plural denoting the fullness of persons within the Godhead. Gerard Hasel,"The Meaning of 'Let Us' in Gen. 1:26," Andrews University Seminary Studies 13 (1975): 58-66. "Made in the image of God, in His intradivine interaction (Gen. 1:26; 11:7), human beings have a kind of 'relational DNA' or 'community gene.'” Bill Donahue and Russ Robinson, Edificando uma igreja de pequenos grupos (São Paulo: Editora Vida, 2003), 35.

${ }^{580}$ Souza points out, "It was God's intention that the intradivine communion, enjoyed within the Godhead, was shared by creatures as an important aspect of the image of God." Souza, "Fundamentos bíblicos," 17.

581 See Thomas Kemper, "The Missio Dei in Contemporary Context," International Bulletin of Missionary Research 38, no. 4 (2014): 188-90.

582 See John Calvin’s commentary: “1 John 1,” Bible Hub, https://biblehub.com/commentaries/calvin/1_john/1.htm.

583 Andrew J. Tompkins, “God`s Mission to the 'Nations' and Hindus: Three Old Testament Narrative Models” (master's thesis, Andrews University, 2012), 32. 
Hesed is used 245 times in the Old Testament and is usually connected with the name Yahweh. Only 63 times is the term used in a secular context. ${ }^{584}$ It appears three times in Ruth $(1: 8 ; 2: 20 ; 3: 10)$, translated as "kindness," "favor," "goodness," "faithfulness," or "graciousness." 585 Taken as a weighty biblical word, ${ }^{586}$ hesed does not have a corresponding word in English that conveys its entire meaning, and should be seen as encompassing attributes such as loyalty, generosity, traditional family duties, and openness to foreigners, among others. ${ }^{587}$ The meaning involves and is based on relationships. ${ }^{588}$

For Glueck, the term prescribes responsible, ethical conduct in an environment of a faith community, and specifies assistance as a duty, or obligation, to those in need. ${ }^{589}$ On the other hand, Sakenfeld argues that in the early biblical tradition, hesed was not a legal obligation, but assistance of a distinctly voluntary character, which possibly went beyond what civil and religious laws required. ${ }^{590}$ For Sakenfeld, hesed was practiced in ancient Israel as an ethical norm, in a family environment, or in community relationships, for people unable to help themselves in an emergency context. ${ }^{591}$ LaCocque has a similar position on applying hesed to a context beyond a standard or legally imposed morality. ${ }^{592}$ 186.

${ }^{584}$ Kristin Moen Saxegaard, Character Complexity in the Book of Ruth (Tübingen: Mohr Siebeck, 2010),

585 Saxegaard, Character Complexity, 186.

${ }^{586}$ Nelson Glueck, Khesed in the Bible (Cincinnati, OH: Hebrew Union College Press, 1967).

${ }^{587}$ Glueck, Khesed in the Bible.

${ }^{588}$ Glueck, Khesed in the Bible.

${ }^{589}$ Glueck, Khesed in the Bible, 38.

${ }^{590}$ Katharine Doob Sakenfeld, The Meaning of Hesed in the Hebrew Bible (Missoula, MT: Scholars Press, 1978), 44-45.

${ }^{591}$ Sakenfeld, The Meaning of Hesed, 78-82.

592 André LaCocque, Ruth: A Continental Commentary (Minneapolis, MN: Fortress Press, 2004$), 31$. 
Roop argues that hesed meets the demands of justice and righteousness towards God and the poor and needy. ${ }^{593}$ Besides, hesed can only be practiced among people who share an ethicalbuilt relationship, exemplified in the Bible by relatives (Gen 47:29), husband and wife (Gen 20:3), host and guest (Gen 19:19; Josh 2:12,14), allies and their relatives (1 Sam 20:8, 14, 15), friends (2 Sam 16:17), ruler and subject (2 Sam 3:8; 2 Chron 24:22), and as merited obligations (Judg 1:24; $1 \mathrm{Kgs} 2: 7) .{ }^{594}$ According to the Bible, God himself practices hesed, through acts of divine strength and power to grant help and salvation to human beings. ${ }^{595}$ This active assistance from God, which reaches both individuals and the community, is based on divine freedom and no obligation. Furthermore, God's hesed is based on his promises, as a manifestation of his grace, forgiveness, or response to human repentance..$^{596}$

In summary, hesed refers to actions that preserve and promote life in an emergency. ${ }^{597}$ The term evokes relational responsibility in the pursuit of justice, based on ethical and voluntary conduct, the fruit of love for God and others in need.

\footnotetext{
${ }^{593}$ Eugene F. Roop, Believers Church Bible Commentary: Ruth, Jonah, Esther (Scottdale, PA: Herald Press, 2002), 269.

${ }^{594}$ Glueck, Khesed in the Bible, 37.

595 See Gen 24; 32:10-13; 2 Sam 7; Mic 7:20; Ps 98; 136; Glueck, Khesed in the Bible, 54-55, 68, 102.

596 Sakenfeld, The Meaning of Hesed, 147-50.

${ }^{597}$ Hans-Jurgen Zobel, "Khesed," in Theological Dictionary of the Old Testament, ed. Gerhard Johannes Botterweck and Helmer Ringgren (Grand Rapids, MI: Eerdmans, 1986), 5:51.
} 


\section{Hesed in the Ruth Narrative}

Many scholars understand hesed as a central theme in Ruth, ${ }^{598}$ the text of which is seen as illustrating the term, describing unusual and faithful acts of loyalty and compassion. ${ }^{599}$ Although the term appears only in the three verses already mentioned, hesed is present in the words and works of the four main characters of the narrative: God, Naomi, Ruth, and Boaz. ${ }^{600}$ Explicitly, Naomi applies hesed to God and his daughters-in-law Ruth and Orpah: "May the Lord deal kindly [hesed] with you, as you have dealt with the dead and with me" (Ruth 1:8).

In this case, the narrative in Ruth confirms that hesed is applied in emergencies. As Roop explains, hesed presupposes an emergency situation, which can present itself in the form of danger, distress, or death, demanding an action that promotes life in the emergency. Also, hesed only happens if the available helper chooses to intervene. ${ }^{601}$ In the narrative, Naomi thanks Ruth and Orpah for the hesed action they took in the context of distress and death that she and her family were experiencing, and wishes that the God of Israel treat them both with the same attitude of hesed.

Again at 2:20, Naomi recognizes God's hesed action; in her view, God continues to show kindness to both the living and the dead by sending Ruth to the fields of Boaz, a close relative and one of the rescuers of the family. Furthermore, in the third text, Boaz refers to Ruth as someone who had twice shown an hesed attitude: when going to the field to seek food and in the

\footnotetext{
${ }^{598}$ See Tompkins, "God's Mission to the 'Nations,"” 34; Roop, Ruth, Jonah, Esther, 19; Holly M. Blackwelder Carpenter, "A Comprehensive Narrative Analysis of the Book of Ruth" (master's thesis, Andrews University, 2005), 128; Saxegaard, Character Complexity, 187-90.

${ }^{599}$ Katharine Doob Sakenfeld, Ruth (Louisville: Westminster John Knox Press, 1999), 11-14.

${ }^{600}$ The concept of hesed is present in all four chapters of Ruth: $1: 6,8-10,14,16-17 ; 2: 4,8-9,11-12,14$ $16,19-21 ; 3: 1,10-13,15 ; 4: 1-15$.

${ }^{601}$ Roop, Ruth, Jonah, Esther, 20.
} 
decision to choose him as a rescuer (3:10). Ruth's ḥesed attitude is confirmed in many texts $(1: 10,14,16-18 ; 2: 2-3,10,18 ; 3: 5-15)$. As mentioned, besides God and Ruth, Naomi and Boaz are also seen in the narrative as people who embody an hesed attitude. Blessed with food abundance through Ruth's work, Naomi returns Ruth's hesed in her plan to seek security for her daughter-in-law (3:1). Other episodes of the narrative also demonstrate Naomi’s hesed action $(1: 8,11-13 ; 2: 20,22 ; 3: 1-4,18 ; 4: 16) .{ }^{602}$ The narrative concludes with Boaz defining a legal plan to protect Naomi and Ruth and maintain their faith in God's care. The plan is consummated with his marriage to Ruth, assuming his role as a rescuer.

\section{A Theology of Mission on Hesed Use in Ruth}

Intriguingly, there is no evidence in the narrative of Naomi's intentional action to convert her daughters-in-law to Judaism. As Tompkins notes, it seems evident that there is no such intentional action, as she tries to persuade her daughters-in-law to return not only to Moab but also to the country's gods $(1: 15) .{ }^{603}$ Even so, Ruth not only decides to follow her mother-in-law, but makes an audible commitment to new citizenship and the God of Naomi, refusing to return to her people and their gods (1:17). Ruth`s attitude raises the question of what factors are most effective in motivating people to change their worldview, especially in a cross-cultural context. In other words, what theology can be extracted from Naomi's hesed attitude that relates to the process of cross-cultural mission?

Glueck argues that an effective way to practice hesed and influence people to adopt a favorable attitude toward God is to maintain confidence in God's faithfulness regardless of

\footnotetext{
${ }^{602}$ See a complete list of references to Naomi's ḥesed attitude in Daniel I. Block, Judges, Ruth, New American Bible Commentary (Nashville: Broadman \& Holman, 1999), 613.

603 Tompkins, "God's Mission to the 'Nations,"” 42.
} 
circumstances. For Glueck, biblical teaching testifies that the most crucial thing in life, and even the reason for existing, is the unconditional and covenantal relationship with God, manifested by hesed. This means maintaining confidence that God is in control of life and circumstances and maintaining an attitude of prayer in the certainty of God's hesed action. ${ }^{604}$ For Hubbard, this attitude of unconditional trust is a positive testimony to God's character. For him, the God revealed in Ruth's book is Yahweh, the covenant God of Israel $(1: 8,9,13,20-21 ; 2: 12 ; 3: 10$, 4:11-12). He breaks the grip of hunger and gives bread to Israel (1:6), guarantees oaths (1:17; 3:13), and gives Ruth refuge $(2: 12) .{ }^{605}$ In this sense, human hesed expressed in relationships with others is a positive demonstration of God's character for those who receive the benefits of the hesed action.

Another element pointed out by Hubbard is the vision of God's sovereignty over the events of history. According to him, Ruth's narrative presents God as a cosmic ruler, by whose providence events unfold, but without dispensing with human agents. ${ }^{606}$ Because of the narrative process in which the author sometimes describes God's providence and sometimes omits it, Hals describes Ruth's book as "a story about the hidden God,"607 and Saxegaard speaks of "God's Silence in Ruth. ${ }^{\prime 608}$ The narrative describes the signs of God's hand in events $(2: 19,29 ; 4: 14)$, then does not mention God directing the encounter between Ruth and Boaz (2:3), but later recognizes that God gave David, a descendant of the couple, to Israel (4:17). Therefore, as Saxegaard says, in the narrative, God is silently present, and at the same time, lets the characters

\footnotetext{
${ }^{604}$ Glueck, Khesed in the Bible, 92-93.

${ }^{605}$ Robert L. Hubbard Jr., The Book of Ruth (Grand Rapids, MI: Eerdmans, 1943), 67.

${ }^{606}$ Hubbard, The Book of Ruth, 69.

${ }^{607}$ Ronald M. Hals, The Theology of the Book of Ruth (Philadelphia: Fortress Press, 1969), 16.

${ }^{608}$ Saxegaard, Character Complexity, 193.
} 
act for themselves, as his representatives. ${ }^{609}$ In this context of God's sovereign control, even though Naomi attributes the misfortunes of her life to him $(1: 20,21)$, she remains confident that God is in control of the circumstances and approaching them with an attitude of hesed (1:8-9; 2:20).

Finally, the narrative recognizes that God acts through acts of hesed done by his human agents. That is, divine providence must be seen working in the ordinary lives of the people described in the narrative. ${ }^{610}$ God is sovereign and has supreme control, but also blesses and thrives on human actions, when his agents unite to fulfill his will. As Hubbard says, wherever human agents practice hesed on behalf of fellow humans, God is at work in them and through them. In such conduct, his will is done on earth and in heaven (Matt 6:10). ${ }^{611}$ In that sense, people seek God's blessing and act as his agents (2:12), and God answers human prayers and pours out blessings $(1: 8-9 ; 2: 12,19-20 ; 3: 10 ; 4: 11-12,14)$. Human actions and relationships ultimately point to God, who influences those actions and relationships. ${ }^{612}$ In short, "God is one who cares for people of all nations." 613

Returning to the theme of Ruth's conversion, from the narrative account, she and her mother-in-law lived together for at least ten years before there was a proposal to return to Judah (1:4). As already mentioned, there seems to have been no planned action on the part of Naomi to convert her (1:8), although this does not mean that an intentionally planned mission is wrong. 1992), 112.

${ }^{609}$ Saxegaard, Character Complexity, 194.

${ }^{610}$ Murray D. Gow, The Book of Ruth: Its Structure, Theme and Purpose (Edmonds, WA: Apollos Press,

${ }^{611}$ Hubbard, The Book of Ruth, 72. See also E. F. Campbell Jr., Ruth (Garden City: Doubleday, 1975), 2930.

${ }^{612}$ Tompkins, "God's Mission to the 'Nations," 43.

${ }^{613}$ Hubbard, The Book of Ruth, 67. 
However, scholars have seen from the narrative that Naomi's hesed attitude must have played a key role in Ruth's decision to abandon her people and the gods they worshiped in favor of her mother-in-law and the God of Israel. Naomi is an example of hesed attitude. Tompkins states that Naomi's kindness, loyalty, and extreme caring attitude made a strong impression on Ruth over the years, leading her to choose to abandon her land and culture at the crucial moment. ${ }^{614}$ For him, Naomi's lifestyle, based on hesed actions, cannot be seen as separate from her religious beliefs. However, he points out that this does not mean a planned action aimed at converting daughters-in-law, but fulfilling the Abrahamic promise to bless the nations. ${ }^{615}$

\section{Missiological Implications of Hesed to Nones}

The theology of hesed seems entirely appropriate for the cultural context of those who claim to be Nones. First, hesed points to the relational aspect of humanity. In Ruth's narrative, hesed is the foundation for a relationship between two people with totally different cultural and religious backgrounds. The Nones of Brazil and the United States, with their differences, peculiar to the two cultures, and their specificities arising from the different subgroups that compose them, have a worldview quite different from the worldview of Christians who maintain the Bible as a rule of faith and practice. As shown in Ruth's narrative, hesed theology can be the basis for a profoundly meaningful interfaith relationship. ${ }^{616}$ An attitude of hesed can serve as a bridge of rapprochement with the Nones and create a relationship with them.

Second, a hesed attitude is a testament to genuine faith, which conveys a positive image of God's character. Naomi does not adopt the hesed attitude to convert her daughters-in-law, but

\footnotetext{
${ }^{614}$ Tompkins, "God's Mission to the 'Nations,"” 42.

615 Tompkins, "God's Mission to the 'Nations,"” 42.

616 Tompkins, "God`s Mission to the 'Nations,"” 51.
} 
as a personal experience of faith, representing God himself in his hesed action on behalf of human beings. Likewise, hesed actions expressing disinterested love can represent God`s character to the Nones and be an effective method to attract them to the faith and the biblical God. It is a kind of evangelism of friendship, or a genuine relationship lived in the context of faith, in which trust is earned by the example of life, which can arouse interest in copying the same lifestyle.

\section{Summary of Principle 1}

Mission founded on relationships through hesed actions is based on the assumption that God assumes a hesed attitude toward human beings. Those who live an experience of faith with God know his character and must be God's instruments to transmit the same hesed attitude to their fellow humans, regardless of religion. The aim is to bring people to knowledge of God as the One source of the hesed manifested by the experience of genuine faith. In this sense, deep, disinterested, and intentional relationships, in the context of hesed faith and actions, can be useful in reaching those who identify as Nones.

\section{Principle 2: Mission Based on the Saving Power of God}

Based on the biblical narrative of Naaman's conversion (2 Kgs 5:1-19), this section argues that manifestations of God's saving power can help the Nones identify him as the true God. However, it does not advocate this miracle as an end in itself, or as an isolated act, but as the culmination of a process that marks God's work in people's lives, the manifestation of power being the high point of the process. Before Naaman's story is examined, a historical and critical analysis of the "power encounter" will help differentiate God's saving power in this work from the concept of power encounter that is common in the contemporary missiological environment. 


\section{The Power Encounter}

All religions tell stories of battles between good and evil and power encounters between good gods and demons. In Hinduism, Rama fights against Ravana; in Buddhism, Buddha fights against Mara; in Islam, Allah fights against Shaitan; and in the tribal religions, territorial gods fight among themselves for conquest. ${ }^{617}$ In the context of tribal religions, it is considered that gods, spirits, and ancestors reside in specific places or objects and protect the people who are part of that locality. In this sense, changes in religious loyalty are associated with the "power encounter." When a community is defeated, people interpret this as meaning the winning community`s gods and spirits are stronger and transfer their spiritual loyalty to them. ${ }^{618}$

The term power encounter was coined and introduced in missiological theory by Tippett in the late 1980s, through his social scientific approach to describe people's movement toward Christianity in the South Pacific islands. According to Tippett, after a power encounter, people in the region changed their religion, no longer fearing their ancient gods. ${ }^{619}$ However, the theme of God`s power associated with the church growth process was introduced at Fuller Theological Seminary in 1982 by C. Peter Wagner and Charles Kraft, with the participation of John Wimber as a visiting professor. The MC510 — Signs, Wonders, and Church Growth class lasted until 1985 , ending with a seminar committee vote. ${ }^{620}$ Subsequently, Fuller seminary allowed Wagner (2000): 115.

${ }^{617}$ Paul G. Hiebert, "Spiritual Warfare and Worldview," Direction: A Mennonite Brethren Forum 29, no. 2

${ }^{618}$ Hiebert, "Spiritual Warfare and Worldview," 116.

${ }^{619}$ Alan R. Tippett, Introduction to Missiology (Pasadena, CA: William Carrey Library, 1987), 82-83. See also Alan R. Tippett, Solomon Islands Christianity (London: Lutterworth, 1967); Alan R. Tippett, People Movements in Southern Polynesia: Studies in the Dynamics of Church-Planting and Growth in Tahiti, New Zealand, Tonga, and Samoa (Chicago, IL: Moody Press, 1971).

${ }^{620}$ The study committee that ended the class published a document intended to reduce the tension between those who defended the topic of the class and those who disagreed. See Lewis B. Smedes, ed., Ministry and the Miraculous: A Case Study at Fuller Theological Seminary (Pasadena, CA: Fuller Theological Seminary, 1987). 
and Kraft to incorporate the concepts of power evangelism into their classes, and in 1988 the World Mission school sponsored an academic symposium on the theme, helping to expand power evangelism in the missiological environment. ${ }^{621}$

The power encounter is an episode of confrontation between God's kingdom and the kingdom of Satan, with the expulsion of demons (exorcism) as its most dramatic form, although it may occur in other circumstances, according to its defenders. ${ }^{622}$ This method has been identified as a facilitator of evangelization. For Wimber, when nonbelievers experience or witness a power encounter, they are moved to a deeper level of spiritual awareness and decide for Christ. ${ }^{623}$ In this perspective, Wimber defends what he calls "power evangelism," or evangelism that includes power encounters and the cognitive teaching of the gospel. ${ }^{624}$ For him, while proclamation is the soul of evangelism, demonstrations of power can catalyze the task of evangelization, producing dramatic results. ${ }^{625}$ Barrett and Johnson attest that for many years the only portion of Christianity that has grown faster than the world population and Islam is the portion that practices supernatural signs and wonders. ${ }^{626}$

\footnotetext{
${ }^{621}$ See Charles H. Kraft, Christianity with Power: Your Worldview and Your Experience of the Supernatural (Ann Arbor, MI: Vine Books, 1989), 1-8; C. Peter Wagner, "Missiology and Spiritual Power," in Paradigm Shifts in Christian Witness: Insights from Anthropology, Communication, and Spiritual Power, ed. Charles E. Van Engen, Darrel Whiteman, and J. Dudley Woodberry (Maryknoll, NY: Orbis Books, 2008), 96-97.

${ }^{622}$ See John Wimber, "Power Evangelism: Definitions and Directions," in Wrestling with Dark Angels: Toward a Deeper Understanding of the Supernatural Forces in Spiritual Warfare, ed. C. Peter Wagner and E. F. Douglas Pennoyer (Ventura, CA: Regal Books, 1990), 27-35. See also Tormod Engelsviken, "Spiritual Conflict: A Challenge for the Church in the West with a View to Future," in Paradigm Shifts in Christian Witness: Insights from Anthropology, Communication, and Spiritual Power, ed. Charles E. Van Engen, Darrel Whiteman, and J. Dudley Woodberry (Maryknoll, NY: Orbis Books, 2008), 116-25.

${ }^{623}$ Wimber, "Power Evangelism," 31.

${ }^{624}$ Wimber, "Power Evangelism," 13-27.

${ }^{625}$ Wimber, "Power Evangelism," 27-28.

${ }^{626}$ David B. Barrett and Todd M. Johnson, World Christian Trends AD 30-AD 2200: Interpreting the Annual Christian Megacensus (Pasadena, CA: William Carey Library, 2003), 25.
} 


\section{Territorial Spirits}

The concept of "territorial spirits," borrowed from the tribal worldview and associated with the theme of power encounter, has been questioned in the missiological context. Although territorial spirits is a term coined by Wagner, the first mission scholar to point out this concept was Timothy Warner of the Trinity Evangelical Divinity School. In 1988 he defended the idea that Satan determines a demon or body of demons for each geographical unit of the world, which are among the principalities and powers mentioned by Paul in Eph 6:12. ${ }^{627}$ For Wagner, it is the work of Satan to "veil the Gospel" (2 Cor 4:3), and trying to prevent the gospel from spreading (2 Cor 2:11), but not being omnipresent, he delegates responsibility for this work to devils. ${ }^{628}$ According to Wagner, nations, regions, cities, tribes, neighborhoods, and other significant social networks and groups of people are controlled by demons, high-ranking evil spirits delegated by Satan. ${ }^{629}$ Thus, Satan is seen as having authority over the earth and delegating that authority to his demonic hierarchy, which rules over jurisdictions of various types and sizes. ${ }^{630}$

Wagner argues that the advancement of evangelization and the church's growth in a particular place occurs after the control of spirits is broken through God's power. ${ }^{631}$ In this perspective, the reigning demons are named, their territories are identified, and they are expelled

\footnotetext{
${ }^{627}$ Timothy M. Warner, “The Power Encounter and World Evangelization, Part 4: The Missionary on the Attack" (1988 Church Growth Lectures, audiotaped by Fuller Seminary Media Services, October 27, 1988).

${ }^{628}$ C. Peter Wagner, "Territorial Spirits," in Wrestling with Dark Angels: Toward a Deeper Understanding of the Supernatural Forces in Spiritual Warfare, ed. C. Peter Wagner and E. F. Douglas Pennoyer (Ventura, CA: Regal Books, 1990), 73-76.

${ }^{629}$ Wagner, "Territorial Spirits," 77.

${ }^{630}$ Chuck Lowe, Territorial Spirits and World Evangelisation? (Borough Green, Kent, Great Britain: Mentor/OMF, 2001), 15.

${ }^{631}$ Wagner, "Territorial Spirits," 77.
} 
and cursed through warfare prayer, paving the way for local evangelization. ${ }^{632}$ The warfare prayer used in this territorial occupation process is called "strategic-level spiritual warfare" (SLSW). ${ }^{633}$ SLSW replaces the approach used by traditional evangelism with an innovative approach based on a thorough analysis of the enemy - the demons that govern the territory to be conquered, and the operating methods used. ${ }^{634}$

However, the idea of territorial spirits has little biblical justification. ${ }^{635}$ Lowe notes that city-states, nations, or empires that opposed ancient Israel served as Satan's instruments against God`s people, but the Old Testament does not support the idea that a particular demon dominated each territory. ${ }^{636}$ Likewise, he argues that there is no evidence in the New Testament that every church, religion, or nation is within a specific demon's jurisdiction. Instead, he points out that texts commonly used to defend territorial spirits (Deut 32:8-9; Ps 82:1-2; Isa 24:21-22; Ezek 28:12-19; Dan 10:13, 20; Rev 2:9, 13, 24; 3:9; 17:9, 18) further demonstrate that organizations, governments, and even individuals who oppose God and his work and people are being instigated by Satan, becoming instruments of God's great enemy in an attempt to prevent the spread of the gospel and the salvation of people. ${ }^{637}$ For Lowe, spiritual warfare is real, and the enemy will always oppose God's work, messengers, and message. However, instead of the

\footnotetext{
${ }^{632}$ C. Peter Wagner, Warfare Prayer: How to Seek God's Power and Protection in the Battle to Build His Kingdom (Ventura, CA: Regal, 1992), 143-50.

${ }^{633}$ Wagner proposes that there are three categories of demons: ground-level—spirits that possess people; occult-level — spirits that empower magicians, witches, warlocks, and shamans; and strategic-level — cosmic or territorial spirits, considered by him the most powerful of the three categories. Wagner, Warfare Prayer, 16-19; C. Peter Wagner, Confronting the Powers: How the New Testament Church Experienced the Power of Strategic-Level Warfare (Venture, CA: Regal, 1996), 21-22.

${ }^{634}$ Lowe, Territorial Spirits and World Evangelisation, 11.

${ }^{635}$ Lowe, Territorial Spirits and World Evangelisation, 29-43.

${ }^{636}$ Lowe, Territorial Spirits and World Evangelisation, 37.

${ }^{637}$ Lowe, Territorial Spirits and World Evangelisation, 43.
} 
SLSW of territorial occupation, he proposes learning the local language and culture, persistence in prayer, diligent work, patient resistance, appropriate use of the Scriptures, patient waiting for the deliverance of God, and the use of indigenous leadership as methods for cross-cultural evangelization, especially in the context of warfare. He also points out that God's supernatural actions occur in times and ways that please God, in answer to prayer, manifested in the form of liberation, protection, healing, and transformation of hearts, among others. ${ }^{638}$

Furthermore, the concept of territorial spirits negates the work of Christ on the cross. ${ }^{639}$ Hiebert points out that all Satan's authority was taken from him by Christ's death and resurrection. After Christ's words, "All authority has been given to me in heaven and on earth" (Matt 28:18), Satan no longer has any authority over the earth, only the authority given to him by his demons and human followers. ${ }^{640}$ Anticipating the victory of redemption, Jesus said, "I saw Satan fall like lightning from heaven" (Luke 10:18). Furthermore, describing the consequences for Satan of his death on the cross, he declared, "Now the prince of this world will be driven out" (John 12:31), and "the prince of this world now stands condemned" (John 16:11). The apostle Paul makes it clear that Christ not only provided human redemption and forgiveness, but also delivered us from the dominion of Satan and the empire of darkness (Col 1:13-14). Moreover, he says that by the triumph of the cross, Christ stripped principalities and powers, and publicly exposed them to contempt ( $\mathrm{Col} 2: 15)$.

Therefore, according to biblical teaching, in spiritual warfare, the cross of Christ represents victory (1 Cor 1:18-25). It represents the summit of Christ's victory over Satan on the

\footnotetext{
${ }^{638}$ Lowe, Territorial Spirits and World Evangelisation, 134-41.

${ }^{639}$ Hiebert, "Spiritual Warfare and Worldview," 117.

${ }^{640}$ Hiebert, "Spiritual Warfare and Worldview," 117.
} 
earthly plane. From the birth of Christ until his death, the enemy tried to defeat or destroy him, using rulers, religious leaders, his family, and his disciples, and acting personally in confrontations with the Lord (Matt 2:13-18; 4:1-11; 16:23; 26:36-46, 57-68; Luke 22:3, 48; John 5:18; 7:1-9). In all cases, Christ was the winner. The cross was the last attempt and the culmination of the confrontation. Satan tried to get Jesus to sin, give up his mission, or misuse his divine power. If Jesus yielded at any of these points, the enemy would be victorious, and the plan of salvation would be destroyed ${ }^{641}$ However, Jesus won again, and definitely. The enemy's wickedness was fully revealed, and Christ died innocently and without sin. "In Scripture, the cross is the demonstration of victory through weakness." ${ }^{\circ 42}$ It is "the victory of righteousness over evil, of love over hate, of God's way over Satan's way." ${ }^{643}$ "All heaven triumphed in the Savior's victory. Satan was defeated and knew that his kingdom was lost.”644

\section{Spiritual Warfare}

The enemy was defeated on the cross, but was not destroyed, and Christ's disciples are still engaged in a real and dangerous war to expand the kingdom of God on this earth. Paul points out,

Our struggle is not against flesh and blood, but against the rulers, against the authorities, against the powers of this dark world and against the spiritual forces of evil in the heavenly realms. Therefore, put on the full armor of God, so that when the day of evil comes, you may be able to stand your ground, and after you have done everything, to stand. (Eph 6:12-13)

\footnotetext{
${ }^{641}$ Hiebert, "Spiritual Warfare and Worldview," 122.

${ }^{642}$ Hiebert, "Spiritual Warfare and Worldview," 122.

${ }^{643}$ Hiebert, "Spiritual Warfare and Worldview," 122-23.

${ }^{644}$ Ellen G. White, The Desire of Ages (Silver Spring, MD: Ellen G. White Estate, 2017), 758.
} 
In this spiritual war, Satan and the demons he commands are angry with Jesus` followers (Rev 12:17, 1 Pet 5:8-9), but God does not forsake his children; he guarantees victory through Jesus (1 Cor 15:57), and indicates the armor with which to face the enemy (Eph 6:13-18). In this process, the most efficient demonstrations of God's power are the transformation of lives, firmness in faith, and witnessing to Christ, regardless of the circumstances. ${ }^{645}$

However, if necessary, God can manifest his power in a supernatural action that frees someone from oppression by the enemy, and even shows his providence by directing human lives and preaching the gospel. Hiebert says that in the matter of the manifestation of God's power, the church faces two dangers. On the one hand, it may avoid seeking this manifestation for fear that it will become magical, leading the church toward a condition of impoverishment and lack of vitality. On the other hand, in the zeal to manifest God`s power, there may be a temptation to become attached to sensationalism and self-aggrandizement. ${ }^{646}$ There is also a risk of being deceived by the enemy's counterfeit signs and lying wonders (2 Thess 2:9-10; Rev 13:13-14; 16:13-14). ${ }^{647}$ However, as the gospel message began in apostolic times with a great manifestation of power, it must end with no less manifestation of the power of God (Joel 2:2832; Acts $2: 17,21 ; \operatorname{Rev} 18: 1) .{ }^{648}$

\section{Mission Based on the Saving Power of God}

This study proposes, based on the narrative of Naaman's healing, that manifestations of the power of God can positively influence the Nones to come to the biblical God. Naaman's

\footnotetext{
${ }^{645}$ Hiebert, "Spiritual Warfare and Worldview," 123.

${ }^{646}$ Hiebert, "Spiritual Warfare and Worldview," 123.

${ }^{647}$ See also Ellen G. White, The Great Controversy (Silver Spring, MD: Ellen G. White Estate, 2017), 513,

${ }^{648}$ White, The Great Controversy, 520.
} 520. 
healing is not the only Old Testament narrative in which a foreigner declares faith in the God of the Scriptures after experiencing or learning of the manifestation of saving divine power. In the stories of Rahab's meeting with the spies in Jericho (Josh 2:1-24), and Sarepta's widow with the prophet Elijah (1 Kgs 17:8-24), declarations of faith in God result from knowledge of divine saving power. Rahab declares,

We had heard how the Lord dried up the Red Sea water for you when you came out of Egypt, and what you did to Sihon and Og, the two kings of the Amorites east of the Jordan, whom you destroyed. When we heard of it, our hearts melted in fear and everyone's courage failed because of you, for the Lord your God is God in heaven above and on the earth below. (Josh $2: 10-11)^{649}$

After witnessing the multiplication of oil and flour, as well as the resurrection of her son through the intervention of the prophet Elijah, Sarepta's widow declares, "Now I know that you are a man of God and that the word of the Lord from your mouth is the truth" (1 Kgs 17:24). "After this second miracle of divine intervention, in which the dead son is brought back to life, the widow acknowledges without any doubts that the God of Elijah is a God of truth." $" 650$

\section{Kings 5:1-19}

The pericope reports the healing of Naaman, the commander of the Syrian army. This study will not analyze all the details of the narrative, but only the points that indicate a connection between the manifestation of God's power through the commander's healing and his declaration of faith in the biblical God. The text says that Naaman was a "great man," highly regarded by the nation`s king, and considered a "war hero." Although the account does not mention them, the likely kings of Syria and Israel at the time were Ben-Hadad II (who reigned

\footnotetext{
${ }^{649}$ See Walter C. Kaiser Jr., Mission in the Old Testament: Israel as a Light to the Nations (Grand Rapids, MI: Baker Books, 2000), 41-42.

${ }^{650}$ Tompkins, "God's Mission to the 'Nations,"” 59.
} 
around 870-842 BC) and Jehoram (who reigned around 852-841 BC), respectively. ${ }^{651}$ Despite all the prestige, Naaman was a leper. The Hebrew expression LXX in the word group $\lambda \varepsilon ́ \pi \rho \varsigma_{\varsigma}$ (leprosy, leprosy), a term used for many types of skin disease. ${ }^{652}$

\section{The Manifestation of God in the Experience of Naaman}

The biblical account gives evidence that God was already working in Naaman's life in various ways, seeking to lead Naaman to recognize him as the only true God. The commander`s conversion resulted from God`s work over time: the manifestation of healing power was only the culmination of a process. ${ }^{653}$ In his speech at the Nazareth synagogue, Jesus said that God healed the Syrian commander of leprosy through Elisha because his heart was more open to the God of heaven than even the lepers of Israel (Luke 4:16-28). This shows that God's grace and the manifestation of his power are not distributed according to nationality or any external characteristic, but according to human willingness to accept God's designs. ${ }^{654}$ Naaman was faithful in what he believed and responded positively to the light he received from heaven. ${ }^{655}$

\footnotetext{
${ }^{651}$ Kaiser, Mission in the Old Testament, 42.
}

${ }^{652}$ Several scholars believe that Naaman's disease was less severe than leprosy as it is known today. It is likely to have been psoriasis, a less severe but still disfiguring skin disease. It was compelling to him due to his social status. In the ancient world, the term leprosy covered several skin diseases. Old translations like Vulgate and Peshitta and modern translations use the term elephantiasis to designate true leprosy. Contemporary interpretations prefer to use the expression "skin disease." See Richard D. Patterson and Hermann J. Austel, 1 Kings-2 Kings, The Expositor's Bible Commentary 3 (Grand Rapids, MI: Zondervan, 2009), 832; Kaiser, Mission in the Old Testament, 43; Walter A. Maier III, "The Healing of Naaman in Missiological Perspective," Concordia Theological Quarterly 61 (1997): 178; Graeme A. Auld, I \& II Kings, Daily Study Bible Series (Philadelphia: The Westminster Press, 1986), 167; T. R. Hobbs, 2 Kings, Word Biblical Commentary 13 (Grand Rapids, MI: Zondervan, 1986 ), 63.

${ }^{653}$ Kaiser, Mission in the Old Testament, 45.

${ }^{654}$ Maier, “The Healing of Naaman,” 196.

${ }^{655}$ Ellen G. White, Prophets and Kings (Silver Spring, MD: Ellen G. White Estate, 2017), 197. 
The first evidence of God's work in Naaman's life appears in the first verse of 2 Kings 5, which says that "through him, the Lord had given Aram victory," or to Syria. As embarrassing as the account may seem, the biblical writer claims that YHWH, the sovereign and creative God,

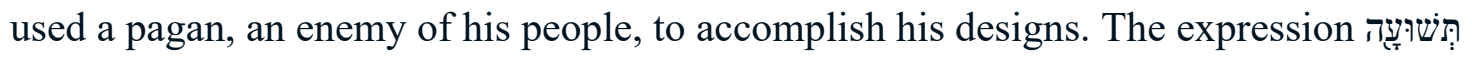
(tə·šū' 'âh), translated as “victory," can also mean "salvation" or "deliverance," demonstrating that God used the commander of the Syrian army as his agent, which involved protection against Assyrian aggression, and also punishment for his people Israel, for their sins. ${ }^{656}$ God allowed Syria's victories over Israel out of love for his people, intending to raise them from their moral weakness. ${ }^{657}$ Divine providence in Naaman's life, granting him military victories, even against the people of Israel, fits in with what scholars call God`s general revelation. General revelation refers to God`s revelation outside of the Scriptures and includes nature, history, and human experience (Rom 1:20; Ps 19:1-4; Acts 7:1-53; Isa 30:21). According to Gulley, general revelation is possible because although the fall defaced the imago Dei (Gen 3:26-27) in human beings, it was not destroyed, and because of the "enmity" (Gen 3:15) given by God to all humans, that is an act of God's grace. ${ }^{658}$ It is an important instrument used by God to reveal himself to humanity because it "displays God's existence, wisdom, power, goodness, and righteousness." ${ }^{659}$ The narrative does not make it clear whether Naaman was aware of God`s providence in his life, but in any case, God found a sensitive heart in him (Luke 4:16-28), and

${ }^{656}$ Maier, "The Healing of Naaman," 178; Auld, I \& II Kings, 167.

${ }^{657}$ White, Prophets and Kings, 198.

${ }^{658}$ Norman R. Gulley, Systematic Theology: Prolegomena (Berrien Springs, MI: Andrews University Press, 2003), 224.

${ }^{659}$ Michael S. Horton, Pilgrim Theology: Core Doctrines for Christian Disciples (Grand Rapids, MI: Zondervan, 2012), 137. 
worked silently in his life, giving him military victories, making general revelation an important divine instrument in the process of his conversion to the true God. ${ }^{660}$

The second piece of evidence of God's work in Naaman's life appears in verses 2 and 3 of the narrative of $2 \mathrm{Kgs} 5$. There was a slave girl in Israel, whose name is unknown, and whom he possibly captured in a victory over Israel and brought to serve his wife. ${ }^{661}$ Despite her condition as a slave, she gave the captain testimony of a resilient faith in the true God and showed confidence that God's power could work for a Gentile pagan. In her practical theology, she demonstrated that God's trust is non-negotiable and does not depend on circumstances. Her unfavorable condition did not impede her faith. She also demonstrated that her lord, however great he was, was not superior to the man of God who was in Israel, and to be healed, he should seek him out. Finally, she showed confidence that God could heal her lord, even though he was an enemy of God's people. ${ }^{662}$ As a witness to the true God, the captive girl fulfilled the purpose the Lord had for Israel, his chosen people. ${ }^{663}$ Naaman took the girl seriously, and impacted by her testimony and speech, decided to go to the prophet, ordered by a letter from Bem-Hadad II to Jehoram, king of Israel (2 Kgs 5:4-5).

The third piece of evidence of God's work in Naaman is found in the commander's coexistence with Israeli culture and religion and his investigation into Israel's religion and God. Although the northern kingdom's religious situation in those days was not favorable, there were always genuine followers of God there. Naaman may have made contact with faithful witnesses

\footnotetext{
${ }^{660}$ Maier, “The Healing of Naaman,” 178.

${ }^{661}$ Patterson and Austel, 1 Kings-2 Kings, 830.

${ }^{662}$ Kaiser, Mission in the Old Testament, 43-44.

${ }^{663}$ White, Prophets and Kings, 190.
} 
of God in Syria through diplomatic business, commercial relations, or war. As Maier says, the Syrian army commander must have wanted to learn about his southern neighbors, who were often his enemies. Perhaps he was interested in learning about some of the miracles that were part of the Israeli tradition or even studied the belief system that dominated his neighbors' culture. ${ }^{64}$ His knowledge about the God of Israel is evident when, even before healing, Naaman refers to him as Elohim, the OT use of the plural noun to refer to the one God of Israel (v. 11). ${ }^{665}$ The fourth piece of evidence of God's work for Naaman came through simple logic used by his servants. Naaman was disgusted that he had not been received with royal honors by Elisha, and by the message that he should go to the Jordan River and wash seven times to be healed and his skin restored. Feeling humiliated by the poor etiquette of demanding that a man of his position go diving in the muddy waters of the Jordan River, Naaman thought that all his effort to travel 120 miles had been in vain, and considering it a joke, decided to return to his country. ${ }^{666}$

Naaman's attitude shows that he was proud, and considered himself superior to Elisha, and also considered his culture, his country, and the Abana and Pharpar rivers of Damascus superior to what he witnessed in Israel (2 Kgs 5:11-12): a kind of obsession with greatness, in Moore's language ${ }^{667}$ For Naaman, since Elisha was inferior to him ethnically and socially_as he thought — his refusal to receive and honor him was a grave fault, an attitude very different

${ }^{664}$ Maier, "The Healing of Naaman," 185.

${ }^{665}$ Maier, “The Healing of Naaman,” 186.

${ }^{666}$ Kaiser, Mission in the Old Testament, 45.

${ }^{667}$ Rick D. Moore, God Saves: Lessons from the Elisha Stories, Journal for the Study of the Old Testament Supplement Series 95 (Sheffield, England: JSOT, 1990), 76. 
from the "prophets" of his land, ${ }^{668}$ resulting in a national insult. ${ }^{669}$ In this perspective, the absolute infinitive אֵֵ2 ('ê·lay), "to myself," appears in verse 11, in the opening of Naaman's speech, to show an emphasis on the certainty that he had to be received with honor by the prophet. The infinitive also emphasizes that Naaman considered it Elisha's duty to meet him because he was "inferior" to the commander. ${ }^{670}$ Disappointed and offended, Naaman decided to abandon the project.

At that moment, the servant officers of the Syrian army who accompanied him used simple God-given logic to persuade Naaman to obey Elisha's command. They said: "My father, if the prophet had told you to do some great thing, would you not have done it? How much more, then, when he tells you, 'Wash and be cleansed!'” (v. 13). After working silently in Naaman's life through the war victories given to Syria and the captive girl's testimony, now God was working through the irrefutable logic of the commander's servants. ${ }^{671}$ In this regard, the servants had more experience than their masters. They were more accustomed to submitting to a senior officer's orders and commands and showing Naaman the benefit promised by obedience. ${ }^{672}$ Faced with this logic, Naaman decided to obey and went to the Jordan River for the washing ritual, exactly as commanded by Elisha.

\footnotetext{
${ }^{668}$ Patterson and Austel, 1 Kings-2 Kings, 191.

669 Auld, I \& II Kings, 168.

${ }^{670}$ See Maier, "The Healing of Naaman," 180; Thomas O. Lambdin, Introduction to Biblical Hebrew (New York: Charles Scribner`s Sons, 1971), 158; Choon L. Seow, A Grammar for Biblical Hebrew (Nashville: Abingdon Press, 1987), 182; Mordechai Cogan and Hayim Tadmor, II Kings, Anchor Bible 11 (New York: Doubleday, 1988), 64; John Gray, I \& II Kings, 2nd ed., The Old Testament Library (Philadelphia: Westminster Press, 1970 ), 506.

${ }^{671}$ Kaiser, Mission in the Old Testament, 45.

${ }^{672}$ Auld, I \& II Kings, 168.
} 
The fifth piece of evidence of God's work for Naaman's conversion was Elisha's attitude. As a spokesman for God and moved by the Holy Spirit's wisdom, the prophet was the divine instrument to help the commander take another step toward conversion to the true God. Thus, he did not receive Naaman personally. First, he wanted to demonstrate that he was not worthy of the honors that Naaman wanted to pay him because God was the one who would give the expected cure. Furthermore, he did not want to show excessive admiration for Naaman and his entourage and gifts, because the commander needed to have his pride broken and humble himself by understanding that all human beings are equal before God. Henry points out that "all of God's commandments test the spirit of men, especially those who guide a sinner to apply for the blessings of salvation." 673 The prophet still wanted to show Naaman that his healing would not come from his own power or any ritual, enchantment, or magic words spoken by him. Furthermore, no heroic or conquering act would give him the cure. He needed to understand that wealth, status, prestige, pomp, royalty, human power, or effort would be neither the source nor the means for healing. ${ }^{674}$

The journey between the prophet's house and the Jordan River served as an instrument of reflection for Naaman, leading to the awareness that if the cure happened it would not be because of the prophet, who stayed away. Nor would it be due to his wealth or merits, which did not influence the prophet at all. Nor could the cure come from the Jordan River's healing properties; otherwise, there would be no lepers in Israel. ${ }^{675}$ It was also an opportunity for Naaman to reflect

\footnotetext{
${ }^{673}$ Matthew Henry, Matthew Henry`s Concise Commentary on the Bible (Grand Rapids, MI: Christian Classics Ethereal Library, 1922), 444.

${ }^{674}$ Maier, “The Healing of Naaman,” 182.

${ }^{675}$ J. Lumby, The Second Book of the Kings, The Cambridge Bible for Schools and Colleges (Cambridge: Cambridge University, 1892), 51.
} 
that Israel had a God and that Elisha was his spokesman. In the case of healing, it would be God's work, his goodness, and his power. ${ }^{676}$

\section{The Manifestation of the Saving Power of God}

Finally, after God's previous work in the life of Naaman - that is, his silent action communicating military victories, the testimony of the captive girl, the coexistence with the religious culture of Israel, the irrefutable logic of the officers' arguments, and Elisha's refusal to receive him — came the most excellent and evident divine action: his healing. Naaman dived into the river seven times and was cured. The transformation involved not only his skin, but also his heart. From then on, the commander showed an internal change that was reflected in his attitude and subsequent words.

Naaman returned to the prophet with a very humble posture, quite different from before, presenting himself four times as a servant of Elisha, and with an attitude of gratitude, offering the prophet the gifts he had brought. Elisha refused to receive the gifts to clarify that he was not like the false prophets who selfishly sought financial gain from their work. Besides, Elisha wanted to reinforce that God and not he had done the miracle, and that God's blessings were the fruit of his grace and could not be purchased (vv. 15-18). ${ }^{677}$

Above all, Naaman gave evidence of converting to the true God through a profound declaration of faith: "Now I know that there is no God in all the world except in Israel" (v. 15). It is true that he still maintained the concept of localized deities, or the idea that each nation had a deity that reigned supreme in that land. In doing so, he limited the scope of God's authority,

\footnotetext{
${ }^{676}$ Maier, "The Healing of Naaman," 182.

${ }^{677}$ Maier, “The Healing of Naaman,” 186.
} 
seeing him as only the God of Israel's territory. Nevertheless, he came to understand that the gods of other nations were false and that only the God of Israel was true. Therefore, the manifestation of God's power was a saving instrument for Naaman, successfully crowning a process of divine intervention in the commander's life. The miracle was the culmination of a process and not just an isolated act.

There is biblical evidence that a divine miracle alone does not guarantee someone's conversion to the true God, but can instead result in more significant hardening and resistance (Matt 12:38-42; John 5:1-18; Acts 16:16-23; 1 Cor 1:18-23). However, when God's power manifests itself as the culmination of a process in which God is already managing to touch a person's life, especially in a polytheistic context, this act can be clarifying and decisive for a conversion to the true God. In Naaman's experience, God's saving power was decisive for his surrender, conversion, and determination to serve only the God of heaven. In this sense, it can be said that God's saving power is an effective missiological instrument when it follows a process in which God, in various ways, is already working in a person's life, and finding a positive response. ${ }^{678}$

\section{The Saving Power of God Applied to Nones}

Just as Naaman's worldview was quite different from the worldview of the Jews of his time, so the worldview of most Nones is quite different from the worldview of Christians who profess to believe in the God of the Bible. The Nones are not a uniform group in their beliefs

\footnotetext{
${ }^{678}$ There is a wide-ranging discussion of Naaman's requests to the prophet Elisha and the prophet's response, "Go in peace" (2 Kgs 5:17-19). Was Naaman asking permission for syncretic religiosity or a mixture of God's pagan worldview with his newfound faith in God? If so, was the prophet approving this worship? This researcher believes not, but due to the limited space, time, and purpose of the research in progress, it is recommended to read the following works to clarify the topic: Andrew Tompkins, "A More Appropriate Mission to Hindus: Another Look at Syncretism in Light of the Naaman Narrative," Journal of Adventist Mission Studies 9, no. 1 (2013): 60-68; Maier, "The Healing of Naaman," 188-96; Kaiser, Mission in the Old Testament, 47-50.
} 
about God. In addition to the 29 percent of American Nones who identify as atheists or agnostics, 68 percent say they believe in God, 53 percent see God as a spiritual energy or force, and only 17 percent believe in the God of the Bible. Also, 18 percent of Nones say they are religious, while 37 percent say they are spiritual but not religious, meaning that they seek a spirituality independent of institutional religiosity. Additionally, 41 percent of them say they pray, while 58 percent never pray. ${ }^{679}$ On the Brazilian side, atheists and agnostics represent only about 5 percent of the Nones, and about 95 percent say they believe in God or a cosmic force. Most of them seek to develop spirituality, but without an institutional link. ${ }^{680}$

Thus, many of the Nones are open to spirituality and seek contact with divine strength. However, God's identity is unclear to most of them, who see him as an energy, a cosmic force, or a spiritual power. Only a minority among the Nones believe in the God of the Bible. Since the majority does not have well-formed ideas about God but believes and is open to spirituality, and since they somehow respond to the work of the Holy Spirit of God, in the light of what they know, manifestations of God's saving power can be a valuable instrument for their conversion. As in Naaman's case, the manifestation of the power of God should not be an isolated act, but the culmination of a process, serving as a watershed, resolving doubts, and providing them with conviction and certainty about the veracity and uniqueness of the biblical God. These circumstances show not only the power of the true God but also his love, providence, and interest in human life (Gen 17:1; Ps 139; 145:9, 17-19; Matt 10:29-30). The manifestation of God's power can take different forms, such as healing, answers to prayer, liberation from the enemy's

\footnotetext{
${ }^{679}$ Pew Research Center, "When Americans Say."

${ }^{680}$ Instituto Brasileiro de Geografia e Estatística, Censo demográfico 2010, table 1.4.1.
} 
power, protection, and freedom from addictions. ${ }^{681}$ However, the church must always maintain the centrality of the gospel and the cross of Christ and never see these miracles as an end in themselves. ${ }^{682}$

\section{Summary of Principle 2}

The mission based on God's saving power is supported by the assumption that God's power can manifest itself in the form, place, and time that he sees fit to help people decide to follow him. In this case, the miracle is not an end in itself or an isolated act, but the culmination of a process characterized by God's action in the person's life with positive responses, within the light received. In this perspective, the manifestation of God's power can be a missiological instrument in work with the Nones, since many are open to spirituality and believe in God or cosmic energy. Contact with God's power, as the culmination of a process, can help them understand the biblical God's uniqueness.

\section{Principle 3: Mission Based on Biblical Instruction}

The biblical narrative of the conversion of Cornelius and his family and close friends, described in Acts 10, demonstrates that biblical instruction is a fundamental part of the Christian mission, especially in a cross-cultural context. The hesed attitude and manifestations of the power of God, described in the previous sections of this chapter, should not be substitutes for biblical instruction, but means by which interested people become qualified to receive biblical teaching. Classified as God-fearing, Cornelius and his family were sympathetic foreigners and

\footnotetext{
${ }^{681}$ Lowe, Territorial Spirits and World Evangelisation, 134-41.

${ }^{682}$ Hiebert, "Spiritual Warfare and Worldview," 116.
} 
semi-adherent to Judaism. This section argues that many Nones, like them, need biblical instruction for a stable conversion to biblical Christianity. Before analyzing the narrative, a brief description of the God-fearers and some evidence that proves this group's existence will be provided to understand the topic under study better.

\section{God-Fearers}

The diaspora of the Jewish people means that Jewish communities have been formed in many parts of the world. In $722 \mathrm{BC}$, the Assyrians conquered the northern kingdom. In $586 \mathrm{BC}$, the Babylonians conquered the kingdom of Judah in the south, and in $70 \mathrm{AD}$, the Romans destroyed Jerusalem. After those moments of defeat, the Jewish people were spread to different countries, and the conquerors occupied their land. ${ }^{683}$ At the time of the Roman Empire, some of the Jewish community's customs and rituals were criticized and ridiculed by their Gentile neighbors, especially circumcision, food laws, and Sabbath observance. ${ }^{684}$ However, many Gentiles admired the Jewish religion because of its antiquity, strict monotheism, ancient wisdom, and code of morality, and the type of community in which its practitioners lived. ${ }^{685}$

From the end of the Second Temple period, many Gentiles became closely related to Jewish communities and their practices, and were identified as proselytes ( $\pi \rho \circ \sigma \eta ́ \lambda v \tau o v)$, Godfearers ( were Gentiles who fully converted to Judaism through circumcision and baptism, God-fearers or

\footnotetext{
${ }^{683}$ See Haim Hillel Ben-Sasson, "Galut,” in Encyclopaedia Judaica, 2nd ed. (New York: Macmillan, 2007), 7:352-63.

${ }^{684}$ See Louis H. Feldman, Jew and Gentile in the Ancient World: Attitudes and Interactions from Alexander to Justinian (Princeton: Princeton University Press, 1993), 123-76.

${ }^{685}$ Feldman, Jew and Gentile, 177-287.

${ }^{686}$ David C. Sim, "Gentiles, God-Fearers and Proselytes," in Attitudes to Gentiles in Ancient Judaism and Early Christianity, ed. David C. Sim and James S. McLaren (New York: Bloomsbury T\&T Clark, 2013), 9, 15.
} 
God-worshippers were Gentile sympathizers who had some measure of commitment to the religion and the local Jewish community. ${ }^{687}$ Although some scholars see the God-fearers as a mere invention of Luke $(10: 2,22,35 ; 13: 16,26,50 ; 16: 14 ; 17: 4,17 ; 18: 7),{ }^{688}$ many others believe that despite the apostle's use of them to defend his theological agenda of evangelization to the Gentiles, there is much evidence to support Acts' testimony about the group. ${ }^{689}$

The primary evidence for the historicity of Acts' account of the God-fearers includes statements by historians Flavius Josephus and Philo, from rabbinic literature, and from Aphrodisias' inscription. Josephus says that many Gentiles joined the Jewish ceremonies in Antioch and, to some extent, were incorporated into the Jewish community. ${ }^{690}$ He mentions many Gentile women attracted to Judaism in Damascus ${ }^{691}$ and others worshiping God in CharaxSpasini, ${ }^{692}$ and mentions Poppaea Sabina, Nero's wife, as a worshiper of God who acted on

${ }^{687}$ Sim, "Gentiles, God-Fearers and Proselytes," 15.

${ }^{688}$ See A. T. Kraabel, "The Disappearance of the God-Fearers," in Diaspora Jews and Judaism: Essays in Honour of, and in Dialogue with, A. Thomas Kraabel, ed. J. Andrew Overman and Robert S. MacLennan (Atlanta, GA: Scholars Press, 1992), 119-30; R. S. MacLennan and A. T. Kraabel, "The God-Fearers-A Literary and Theological Invention," in Diaspora Jews and Judaism: Essays in Honour of, and in Dialogue with, A. Thomas Kraabel, ed. Andrew J. Overman and Robert S. MacLennan (Atlanta, GA: Scholars Press, 1992), 131-43.

${ }^{689}$ See Sim, "Gentiles, God-Fearers and Proselytes," 15; Feldman, Jew and Gentile, 342-82; Irina Levinskaya, The Book of Acts in its First Century Setting: Diaspora Setting (Grand Rapids, MI: Eerdmans, 1996), 5:51-126; Emil Schürer et al., The History of the Jewish People in the Age of Jesus Christ (175 B.C.-A.D. 135) (Edinburgh: T. \& T. Clark, 1973-87), 3:160-69; S. J. D. Cohen, The Beginnings of Jewishness: Boundaries, Varieties, Uncertainties (Berkeley: University of California Press, 1999), 171-74; T. L. Donaldson, Judaism and the Gentiles: Patterns of Universalism (Waco: Baylor University Press, 2008), 469-82; P. Trebilco, Jewish Communities in Asia Minor (Cambridge: Cambridge University Press, 1991), 145-66; J. A. Overman, "The GodFearers: Some Neglected Features," in Diaspora Jews and Judaism: Essays in Honour of, and in Dialogue with, A. Thomas Kraabel, ed. J. Andrew Overman and Robert S. MacLennan (Atlanta, GA: Scholars Press, 1992), 145-52; J. Reynolds and R. Tannenbaum, Jews and Godfearers at Aphrodisias: Greek Inscriptions with Commentary (Cambridge: Cambridge Philological Society, 1987), 48-66.

${ }^{690}$ Flavius Josephus, Bellum Judaicum, ed. E. Cardwell and R. M. Pollard, The Latin Josephus Project, https://sites.google.com/site/latinjosephus/bellum-judaicum/, bk. 7, chap. 45.

${ }^{691}$ Josephus, Bellum Judaicum, bk. 2, chap. 560.

${ }^{692}$ Flavius Josephus, Antiquities, ed. R. M. Pollard, J. Timmermann, J. di Gregorio, M. Laprade, and J.-F. Aubé Pronce, The Latin Josephus Project, https://sites.google.com/site/latinjosephus/antiquities/, bk. 20 , chap. 34. 
behalf of the Jews. ${ }^{693}$ Philo refers to a Gentile named Petronius, who had assimilated some elements of the religion and culture of the Jews, and was also helpful to the Jewish community. ${ }^{694}$ Rabbinic literature emphasizes the difference between Gentiles fully converted to Judaism and those who were sympathizers but did not follow all Mosaic laws. ${ }^{695}$ The inscription of Aphrodisias, dating from the third century $\mathrm{AD}$, in the period of the third Jewish diaspora, mentions on one side a list of members of an institution called "the decany," donating to a Jewish community in Asia Minor. The donor list includes thirteen Jews by birth, three proselytes, and two God-worshipers. On the other side of the inscription is another list of donors, supposedly considered less critical, including fifty-three Jews by birth and twenty-two God-worshipers. ${ }^{696}$ Luke demonstrates that many of the God-fearers of his time attended synagogues; some prayed and gave alms (Acts 13:13-16; 10:2). Philo and Josephus confirm Luke`s account, stating that many of them observed the Sabbath, fasting during the Day of Atonement, and some Jewish dietary regulations. Other God-fearers contributed to the annual temple fee ${ }^{697}$ The literature, in general, confirms that God-fearers were sympathetic to some aspects of Judaism, often becoming members of the Jewish community, but did not completely convert to the Jewish religion. They

${ }^{693}$ Josephus, Antiquities, bk. 20, chap. 195.

${ }^{694}$ Philo, Legatio ad gaium, trans. E. M. Smallwood (Leiden: E. J. Brill, 1961), 245.

${ }^{695}$ See W. G. Braude, Jewish Proselyting in the First Five Centuries of the Common Era: The Age of the Tannaim and Amoraim (Providence: Brown University Press, 1940), 137-38; Feldman, Jew and Gentile, $353-55$.

${ }^{696}$ See Sim, “Gentiles, God-Fearers and Proselytes," 16-17; Margaret H. Williams, "The Jews and Godfearers Inscription from Aphrodisias: A Case of Patriarchal Interference in Early 3rd Century Caria?" Historia: Zeitschrift für alte Geschichte 41, no. 3 (1992): 297-310, http://www.jstor.org/stable/4436248.

${ }^{697}$ See Philo, On Abraham. On Joseph. On Moses, trans. F. H. Colson, Loeb Classical Library 289 (Cambridge, MA: Harvard University Press, 1935), 459-61; Josephus, Antiquities, bk. 214, chap. 110; Josephus, Bellum Judaicum, bk. 2, chap. 463. 
probably continued to worship other gods besides Israel's God and remained outside the covenant community. The Jews expected them to convert, but they were not forced to do so. ${ }^{698}$

Luke points to God's effort to lead the early Christian church to evangelize the Gentiles. Scholars understand that it was part of the apostle's theological agenda to show the transition from evangelizing Jews to the Gentile world and accept the conversion of Gentiles to Christianity without the need to first become full converts to Judaism. ${ }^{699}$ In this sense, he highlights the conversion of the Ethiopian eunuch, an official of Queen Candace, the first Gentile to become a Christian (Acts 8:26-40). He puts even greater emphasis on Cornelius, a Roman centurion who was converted along with his family and close friends (Acts 10:1-48). Through both narratives of the conversion of Gentile God-fearers, and mainly through the apostolic ratification that took place at the Jerusalem Council of Leaders (Acts 15), Luke points out the continuity between the Jewish heritage of the church, started in Jerusalem and described in the Gospels, and the Gentile mission described in Acts. ${ }^{700}$ As Keener says, Luke emphasizes that the Gentile mission is an idea of God. ${ }^{701}$

Both episodes of conversion of God-fearers to Christianity, according to Luke's description, had an essential foundation in biblical instruction. A more detailed analysis will be made of Cornelius's conversion narrative because of the wealth of information contained in the text. Based on this narrative, it is assumed that biblical instruction is foundational for converting

\footnotetext{
${ }^{698}$ See Christopher J. Cornthwaite, "Wayward Jews, God-Fearing Gentiles, or Curious Pagans? Jewish Normativity and the Sambathions," Journal for the Study of Judaism 48 (2017): 285; Williams, "The Jews and Godfearers Inscription," 301; Sim, "Gentiles, God-Fearers and Proselytes," 17.

${ }^{699}$ See Sim, "Gentiles, God-Fearers and Proselytes," 15; Craig S. Keener, Acts: An Exegetical Commentary (Grand Rapids, MI: Baker Academic, 2013), 2:862.

${ }^{700}$ Keener, Acts: An Exegetical Commentary, 2:833-34.

${ }^{701}$ Keener, Acts: An Exegetical Commentary, 2:863.
} 
the Nones, many of whom, like the God-fearers, are open to communication with the transcendent. The narrative analysis will be limited to the aspects relevant to this study and will not cover all the pericope details.

\section{Acts 10:1-48}

The narrative describes the conversion of a God-fearing Roman officer, with his entire household, without first having to be circumcised or become a proselyte. Cornelius was a centurion of the Roman army, serving in Caesarea, in one of the auxiliary cohorts stationed in Judea. ${ }^{702}$ A centurion commanded a group of sixty to one hundred soldiers and also filled an administrative role in a small region. ${ }^{703}$ At that time, Caesarea was dominated by Gentiles ${ }^{704}$ who had the goddess Fortune as their patron deity. ${ }^{705}$ As a God-fearer, Cornelius was pious, gave alms to the people, and regularly prayed to the God of Israel. The account shows that he was remembered and respected for his devotion and charity not only by God, but also by the local Jewish community (vv. 4, 22). However, he lacked knowledge of the essential details surrounding God's redemptive plan, which only biblical instruction could remedy.

\section{The Saving Power of God}

In the narrative, God manifested in different ways to convert Cornelius and carry out his plan for the Gentile mission. An angel appeared to Cornelius in a vision around the ninth hour

\footnotetext{
${ }^{702}$ An auxiliary cohort was a group of 1,000 soldiers. See F. F. Bruce, The Book of the Acts, New International Commentary on the New Testament (Grand Rapids, MI: Eerdmans, 1998), Kindle Location 7805.

${ }^{703}$ Keener, Acts: An Exegetical Commentary, 2:847, 849.

${ }^{704}$ Robert J. Bull, “A Mithraic Medallion from Caesarea,” Israel Exploration Journal 24, no. 3, 4 (1974): 187-90; Gary Lease, "The Caesarea Mithraeum: A Preliminary Announcement," Biblical Archaeologist 38, no. 1 (1975): 2-10.

${ }^{705}$ Keener, Acts: An Exegetical Commentary, 2:839.
} 
(vv. 3, 4) - three in the afternoon. The occurrence of the vision at the ninth hour, one of the hours of prayer in the temple (3:1), and the angel's use of the terms "ascending" and "memorial" (10:4) about Cornelius's prayers and alms allude to the sacrificial Leviticus system and may be evidence that the centurion practiced regular prayer. ${ }^{706}$ In the vision, the angel told Cornelius to send for the apostle Peter, who was in the city of Joppa about thirty miles away, ${ }^{707}$ to be instructed by him (vv. 5, 22, 11:13, 14).

The next day, God manifested himself to Peter in Joppa, at the house of Simon, a tanner, which was a profession with low social status in the Roman world. ${ }^{708}$ Around the noon hour, Peter was in prayer when he received a vision from God, as did Cornelius when the angel visited him (9:30). Although the sixth hour was not a time for public prayer, godly Jews, like Daniel, prayed three times a day and practiced it (Dan 6:10; Ps 55:17). ${ }^{709}$ This prayer outside the regular time practiced by Jews in general also reinforced the apostolic goal of dedication to prayer and the ministry of the Word (Acts 6:4). In the vision, Peter saw a sheet descending from the sky full of clean and unclean animals, and heard God's voice saying to him, "Kill and eat" (v. 13). Peter refused to eat unclean animals, following the guidance of Lev 11, but God told him three times not to consider impure what he had purified (vv. 14-16). Peter found that order of God strange,

${ }^{706}$ The expression "ascended" ( $\left.\dot{\alpha} \varepsilon \dot{\beta} \eta \sigma \alpha v i s\right)$ relates to the smoke of a burnt-offering sacrifice, 'ôlāh of Leviticus, and the expression "memorial" ( $\mu v \eta \mu$ ó $\sigma v v o v)$ relates to the cereal offering that was burnt and presented to God (Lev 2:2). See Bruce, Book of the Acts, Kindle Locations 7484-85, 7837-38.

${ }^{707}$ According to Bock, Joppa was thirty-one miles from Caesarea. See Darrell L. Bock, Acts, Baker Exegetical Commentary on the New Testament (Grand Rapids, MI: Baker Academic, 2007), 1146, iBook.

${ }^{708}$ Keener, Acts: An Exegetical Commentary, 2:865.

${ }^{709}$ Scholars see prayer as a central issue in Luke's books. In this sense, it is not by chance that he associates God's manifestation in the Cornelius conversion narrative with the practice of prayer. See Bruce, Book of the Acts, Kindle Location 7519; Keener, Acts: An Exegetical Commentary, 2:870; William Oscar Emil Oesterley, The Jewish Background of the Christian Liturgy (Oxford: Clarendon, 1925), 125; Joaquim Jeremias, New Testament Theology (New York: Scribner's, 1971), 188. 
and he meditated, trying to understand it. In that instant, God manifested again to tell the apostle that the messengers of the Gentile Cornelius were coming for him, and that he should believe what they say and follow them because they were sent by God (vv. 17-21, 11:12).

Peter concluded that the vision was not about food, but about God's purpose to save the Gentiles. He said, "God has shown me that I should not call any person common or unclean" (v. 28), and, "Truly I understand that God shows no partiality," (v. 34). The apostle clarified that Christ is Lord of all (v. 36). In other words, God has no favorite nation, but accepts anyone from any nation that responds to his call (vv. 34-35). ${ }^{710}$ To further show that salvation is not just a privilege of the Jews and that the church should follow Christ's mandate to reach the whole world with the gospel (Matt 28:18-20), the Holy Spirit was poured out on Cornelius and those with him, even while Peter was still teaching them (vv. 4-48, 11:15-18). The Holy Spirit thus was enabling the group to participate in the same mission for the rest of the world. ${ }^{711}$

Therefore, the manifestation of God's saving power in these parallel visions was crucial both to convince Peter about the Gentile mission and to convert Cornelius with his family and friends. The fact of the double and complementary visions reinforced their validity and added credibility to the Gentile mission, as an antidote to individual subjectivity. ${ }^{712}$ The various elements involved in the visions, such as the angelic presence, God's voice, the manifestation of the Holy Spirit, and the divine direction in every detail of the narrative, filled the hearts of those

\footnotetext{
${ }^{710}$ Keener, Acts: An Exegetical Commentary, 2:904, 908.

${ }^{711}$ Keener, Acts: An Exegetical Commentary, 2:917.

${ }^{712}$ Keener, Acts: An Exegetical Commentary, 2:867.
} 
involved with trust to the point of submitting to God's will. ${ }^{713}$ Reconciliation initially required divine intervention. ${ }^{714}$

\section{The Hesed Action}

There is ample evidence of hesed action in the story of Cornelius, both from God and from the various characters involved. Hesed actions of love, kindness, inclusion, and respect, restore relationships, making them essential in the mission, especially in a cross-cultural context, ${ }^{715}$ and they were fundamental in breaking the barriers between Jews and Gentiles. ${ }^{716}$ Luke clearly shows the hesed actions practiced by Cornelius. He is described as a godly man who helped the poor with alms and had a good reputation with the Jewish nation (vv. 4, 22). Peter also practiced hesed actions when he kindly received and hosted Cornelius's envoys, and then when he stayed for several days at the centurion's house, overcoming prejudice, as part of the mission of evangelizing him, along with his relatives and friends. In verse 33, the note regarding Peter's kindness ( $\kappa \alpha \lambda \tilde{\omega} \varsigma$ - kalōs) in responding to Cornelius' call is an acknowledgment that he had deviated from common Jewish practice (vv. 23, 33, 48). ${ }^{717}$ The pious soldier and the two servants sent by Cornelius to Peter also demonstrated hesed action in describing their lord as an upright, kind, God-fearing man who enjoyed the support and admiration of the Jews who knew him (v. 22). Above all, the narrative is replete with God's hesed actions. He valued the centurion's prayers and alms, which went up to him like incense or

\footnotetext{
713 According to Bock, the narrative clearly reveals divine providence. Everything there is coordinated by God. See Bock, Acts, 1124, 1166, 1169.

${ }^{714}$ Keener, Acts: An Exegetical Commentary, 2:888.

715 See Hubbard, The Book of Ruth, 38; Carpenter, “A Comprehensive Narrative Analysis,” 129.

${ }^{716}$ See Bruce, Book of the Acts, Kindle Locations 7546-48.

${ }^{717}$ Bock, Acts, 1168.
} 
sacrificial smoke. God told Peter three times that he had purified Cornelius, ${ }^{718}$ and encouraged the apostle to trust the centurion's messengers as being sent by himself (vv. 4, 20). Also, Peter claimed that God is impartial and does not discriminate against anyone, but accepts everyone who fears and seeks him (vv. 34-35). The word $\pi \rho 0 \sigma \omega \pi \circ \lambda \eta ́ \pi \tau \eta \varsigma$ (prosōpolēmptēs) expresses that God is impartial, conveying the idea that God "receives faces" or "lifts up the face" in acceptance. ${ }^{719}$ Finally, the Holy Spirit was poured out to the Gentile hearers to show God's approval of their faith (vv. 4, 20, 44).

However, in the narrative, it is clear that hesed actions and the manifestation of the power of God, although essential in converting the group of Gentiles, were not enough. God has provided a means of sending biblical instruction to those concerned so that the conversion process is carried out on solid grounds.

\section{Mission Based on Biblical Instruction}

Luke points out several pieces of information in the narrative that demonstrate the central role of biblical instruction in converting to the Christian faith. Hesed actions and the manifestation of God's power are not substituting for biblical instruction, but means by which the interested person becomes open to listen to the basic instructions for conversion. In that sense, God always uses humans as his agents. The process of discipleship requires the participation of someone who is already a disciple and can testify to the gospel's power through experience. By directing Cornelius to seek the saving message through Peter, rather than communicating it directly or through his angel, God was maintaining the pattern of delivering

\footnotetext{
${ }^{718}$ As in the episode of Saul's conversion, the repetition three times here is for the sake of emphasis. God does not want to leave any doubt about his position regarding the equality of human beings. See Keener, Acts: An Exegetical Commentary, 2:881.

${ }^{719}$ Bock, Acts, 1170.
} 
the biblical message through human agents (Acts 1:8; Matt 24:14; 28:18-20; Mark 16:15-16). ${ }^{720}$ White emphasizes that God chose to use human beings, not angels, as his agents through which the gospel exercises its transforming power in the minds and hearts of seekers. "God does not choose angels who have never fallen, but human beings, men of like passions with those they seek to save."721

The angel clearly instructed Cornelius to send for Peter, giving details of where he was in Joppa, because the apostle's instruction would be vital to him and his household (v. 5). When Cornelius' messengers found the apostle, they claimed that a holy angel had instructed their master to call Peter to his home and to hear his words (v. 22). When Peter arrived at Cornelius' house, Cornelius had gathered his relatives and friends there, in God's presence, ready to hear everything that had been commanded by the Lord (v. 33). Finally, when Peter described Corneliu's conversion in the Jerusalem's council, he said that the angel had said to Centurion to call him because he would say words by which he and his entire household would be saved (11:14). Therefore, it is clear that Peter's instruction was fundamental to the group's decision to follow the Christian faith and their maturation in spiritual experience. For this reason, the listeners requested that Peter remain with them for a few days (v. 48).

Although we do not know how Peter ended his teaching in that first meeting with the interested Gentiles at Cornelius' house, due to the interruption made by the Holy Spirit (v. 44), the topics presented are enlightening. He first rejected idolatry by preventing Cornelius from worshiping him (vv. 25-26). The expression $\pi \rho 0 \sigma \varepsilon \kappa v ́ v \eta \sigma \varepsilon v$ (prosekynēsen) can mean "paying

\footnotetext{
${ }^{720}$ Pankau and Siemon-Netto point out that several reports of direct revelations from God to non-Christians today often include the instruction to seek specific people already mature in the faith to obtain biblical teaching on the Christian faith. See Matthias Pankau and Uwe Siemon-Netto, "The Other Iranian Revolution," Christianity Today, July 2012, 45.

${ }^{721}$ Ellen White, The Acts of the Apostles (Silver Spring, MD: Ellen G. White Estate, 1911), 134.
} 
homage" or "worshiping." Peter understood that Cornelius' act was more than a tribute and showed excessive deference to him, so he did not allow it. ${ }^{722}$ The expression "I am also a man" (v. 26) means that Peter was not a "divine man" in the Greek sense of the term. ${ }^{723}$ As a Godfearer, Cornelius was perhaps not so orthodox on the subject of worship. God-fearers lived in a pagan context, and many of them worshiped other gods along with the God of Israel that they came to admire. ${ }^{724}$ Furthermore, being a centurion, Cornelius may have had to venerate Caesar as a deity, a common practice in the Roman empire. Thus, he may have considered Peter a divine man or an angel, and the apostle needed to correct this error. Peter's instruction became even more significant because they were in the city that bore the emperor's name. ${ }^{725}$

Jesus was the central topic of Peter's speech. Luke says that Peter "opened his mouth" ( $\alpha$ voí $\alpha_{\varsigma}$ - anoixas) (v. 34), a solemn expression with biblical roots (Job 3:1; Matt 5:2; Acts 8:35; 18:14), showing the communication of authoritative content. ${ }^{726}$ The apostle presented his new theological insight that God is no respecter of persons (vv. 34, 35), a typically Christian expression, found only in the NT (Rom 2:11; Eph 6:9; Col 3:25; Jas 2:1; 1 Pet 1:17). ${ }^{727}$ He went

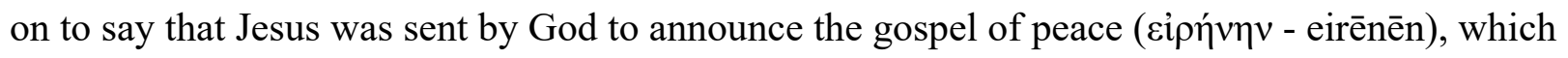
made no distinction between human beings, and that God was Lord of all (v. 36). This concept of peace provided by the gospel not only unites everyone under the lordship of Christ, eliminating

\footnotetext{
722 John B. Polhill, Acts, New American Commentary 26 (Nashville: Broadman Press, 1992), 258.

${ }^{723}$ Bock, Acts, 1163.

${ }^{724}$ See Cornthwaite, "Wayward Jews," 285; Sim, “Gentiles, God-Fearers and Proselytes," 17.

${ }^{725}$ Levinskaya, Book of Acts, 5:121; Keener, Acts: An Exegetical Commentary, 2:890-92.

${ }^{726}$ J. M. Bassler, "Luke and Paul on Impartiality," Biblica 66 (1985): 546-52; Bruce, Book of the Acts,

${ }^{727}$ Bock, Acts, 1170.
} Kindle Location 7673. 
distinctions, but also relates to the OT concept of shalom, meaning well-being, the result of the relationship between the person and God (Ps 29:11; 72:7; 85:8-10; Prov 3:17; Isa 48:18; 54:10; Ezek 34:25-29). ${ }^{728}$ In other words, Peter was saying that it is not possible to assess a person's conversion potential based on their ethnicity. ${ }^{729}$ Barrett points out that Paul developed the same theme by emphasizing that Jews and Gentiles, without distinction, are under the lordship of Christ, being responsible to God for $\sin .{ }^{730}$

In this sequence, Peter presented the divinity as united around the plan of salvation, extended to the whole human race. God, the Father, was the plan's source, took the initiative, and sent Jesus. Jesus was the central point of the plan, as the redeemer of humanity. Furthermore, the Holy Spirit was the transmitter of divine power, anointing Jesus for the saving mission. The Spirit also confirmed the Gentile mission of the gospel by falling upon the assembled group and showing that Jews and Gentiles are equal in Christ (vv. 38, 44). ${ }^{731}$ The act of Gentile mission represents God's action and will in harmonious work. ${ }^{732}$

Peter continued his speech by demonstrating that Jesus was the promised Messiah of Bible prophecy, through whom there was remission of sins and forgiveness under the witness of all prophets - a typical way for Luke to summarize the biblical message. ${ }^{733} \mathrm{He}$ explained that Christ fulfilled his earthly ministry, died, and rose on the third day. Finally, Peter explained that the preaching of the gospel was a mandate of Christ. He also pointed out that Christ exercised a

\footnotetext{
${ }^{728}$ Bock, Acts, 1173.

${ }^{729}$ Keener, Acts: An Exegetical Commentary, 2:897.

${ }^{730}$ C. K. Barrett, Acts 1-14, International Critical Commentary (Edinburgh: T\&T Clark, 1994), 519.

${ }^{731}$ B. R. Gaventa, Acts, Abingdon New Testament Commentaries (Nashville: Abingdon, 2003), 173-74.

${ }^{732}$ Bock, Acts, 1190.

${ }^{733}$ Keener, Acts: An Exegetical Commentary, 2:916.
} 
heavenly ministry as the Savior for those who believed in his name, and as the judge of the living and the dead (vv. 39-43). According to Keener, here Peter was clarifying God's impartiality in judgment between Jews and Gentiles, a topic also addressed by Paul in Rom $2 .{ }^{734}$ The way Peter explained the divinity of Jesus has been seen as intended to correct the typical Gentile usage of the term for exalted lords. ${ }^{735}$

According to Bock, the resurrection explains the position and role that Jesus plays today in heaven. ${ }^{736}$ Stott, on the other hand, points out that without the person of Jesus and his heavenly ministry on our behalf, there is no gospel. ${ }^{737}$ The story of Cornelius demonstrates the insufficiency of the seeking process. There is a difference between being a seeker or interested and entering into an intimate relationship with God. Cornelius' journey was only completed when he received biblical instruction and could solidly and consciously ally with the biblical God. ${ }^{738}$

Witherington notes that Luke was sensitive to Peter's rhetorical use of Scripture in the Gentile context: he used less Scripture than in his Acts 2 and 3 speeches for a Jewish audience. However, the Scriptures remained the source and template of his teaching. ${ }^{739}$ Peter adapted the biblical instruction to his listeners' needs, punctuating the topics that were most relevant to his audience. He also centered his teaching of the Scriptures on the person of Jesus, showing that all

\footnotetext{
${ }^{734}$ Keener, Acts: An Exegetical Commentary, 2:904.

${ }^{735}$ Keener, Acts: An Exegetical Commentary, 2:908.

${ }^{736}$ Bock, Acts, 1192.

${ }^{737}$ John R. W. Stott, The Message of Acts, The Bible Speaks Today (Downers Grove, IL: InterVarsity,

${ }^{738}$ Bock, Acts, 1193.

${ }^{739}$ See Ben Witherington III, The Acts of the Apostles: A Socio-Rhetorical Commentary (Grand Rapids,
} 1990), 190-91. MI: Eerdmans, 1988), 355-56. 
biblical instruction must not only point to Christ, but center on him. Just as there can be no complete conversion without biblical content and parameters, biblical instruction must center on Christ or it will become arid and lifeless. ${ }^{740}$

\section{Missiological Implications of Biblical Instruction to Nones}

Biblical instruction is just as pertinent to the conversion of the Nones as it was to converting God-fearers in Peter's time, at least for those open to the transcendental relationship. As already seen, 37 percent of American Nones and a large proportion of Brazilian Nones claim to be spiritual, but not religious (SBNR) ${ }^{741}$ This group does not accept purely scientific-atheistic alternatives, believing they lack a spiritual basis that gives meaning and direction to human life. ${ }^{742}$ While they defend a worldview that recognizes a cosmic level of existence, this group has a relationship with the transcendent unrelated to religious or dogmatic parameters. They value an experiential spirituality, subjective and focused on the inner self, reflecting what Gedicks calls contemporary spirituality represented by postmodern beliefs such as freedom, individuality, relativism, and pluralism. ${ }^{743}$ For this reason, SBNRs are called "metaphysical believers,"774

\footnotetext{
${ }^{740}$ See A. M. Hodgkin, Christ in All the Scriptures (Westwood, NJ: Barbour, 1989); Bryan Chapell, ChristCentered Preaching: Redeeming the Expository Sermon (Grand Rapids, MI: Baker Academic, 2018), 247-85;

Walter C. Kaiser Jr., The Messiah in the Old Testament (Grand Rapids, MI: Zondervan, 1995), 232-33.

${ }^{741}$ Fuller, Spiritual, But Not Religious, 19.

${ }^{742}$ Fuller, Spiritual, But Not Religious, 19; Roof, A Generation of Seekers, 33, 41.

${ }^{743}$ Gedicks, “Spirituality, Fundamentalism, Liberty,” 1197-1208.

${ }^{744}$ Roof, A Generation of Seekers, 178.
} 
"people without a church,"745 "spiritual seekers,"746 or followers of "New Age spirituality,"747 "liquid spirituality,"748 and "à la carte religion,"749 among others. They choose beliefs and practices based on the meaning and benefits they provide for their personal lives. ${ }^{750}$

As demonstrated by Cornelius' experience, spirituality alone is not sufficient for a complete and accurate conversion to God and biblical Christianity. The seeking process can only be complete when the interested party makes a deep commitment to God while consciously under biblical instruction, as there is no real conversion into the void. ${ }^{751}$ However, Peter's rhetoric in his speech to the God-fearers also teaches us that biblical instruction must be tailored to the needs of those interested. The themes must be relevant to the audience and their context. Furthermore, biblical instruction for the Nones must be centered on Christ as the great physician of the soul, who can meet the human person`s deepest needs. ${ }^{752}$ Biblical beliefs and practices, when scored according to the needs of listeners, and when centered on Christ, will bring meaning and benefits to the lives of the Nones on an individual level.

\footnotetext{
${ }^{745}$ Fuller, Spiritual, But Not Religious, 4.

${ }^{746}$ Roof, A Generation of Seekers, 8.

${ }^{747}$ Roof, A Generation of Seekers, 98-99; D`Antonio, Heaven on Earth, 20.

${ }^{748}$ Bauman, Modernidade líquida, 8-46.

${ }^{749}$ Roof, A Generation of Seekers, 73.

${ }^{750}$ Roof, A Generation of Seekers, 57; Gedicks, “Spirituality, Fundamentalism, Liberty,” 1218.

${ }^{751}$ Bock, Acts, 1193.

${ }^{752}$ Hodgkin, Christ in All the Scriptures, 1989; Chapell, Christ-Centered Preaching, 247-85; Kaiser,
} Messiah in the Old Testament, 232-33. 


\section{Summary of Principle 3}

The narrative of the conversion of Cornelius and his family and friends - the Godfearers - attests to biblical instruction's fundamental role in the conversion process, especially in cross-cultural contexts. Biblical instruction is essential for sound and conscious conversion, as there is no conversion in a void. The hesed attitude and the manifestation of God's saving power are essential, but only as a means by which the interested person becomes open to biblical teachings. God always uses human instruments for this teaching because the testimony of disciples who have already experienced God's saving power is irrefutable and will have a strong influence on listeners.

The narrative also demonstrates that Christ must be the center of biblical teaching, and the themes must be adapted to the context of the listeners and follow their needs. The seeking process is not enough. Cornelius only became a full Christian when, based on the biblical instruction he received, he entered into a personal commitment to the biblical God and salvation through Christ. Just as Peter's instruction was essential to convert the group of God-fearers to the Christian faith, biblical instruction is essential for the conversion of the Nones, especially for those classified as seekers. They are open to spiritual experience, and if biblical beliefs and practices are presented according to their needs, and centered on Christ, they will bring meaning and benefits to them at the individual level. As in the case of the God-fearers, the Nones' spirituality will become complete and established on the concrete basis of biblical instruction. Therefore, the hesed attitude and the manifestation of God's saving power, followed by biblical instruction, are missiological principles highly recommended for evangelization of the Nones. The next section will further clarify the adaptation of biblical instruction to the audience when describing principle 4 of this study: mission grounded in contextualization. 


\section{Principle 4: Mission Based on Contextualization}

As already seen in the previous sections, the hesed attitude, the manifestation of God's saving power, and biblical instruction are three fundamental principles for cross-cultural mission and work among the Nones. Contextualization is the fourth principle in the series. Used complementarily, these principles form a basic set of positive actions that facilitate cross-cultural mission, including among the Nones.

Stan May writes that the great challenge of contextualization is to convey the "neverchanging Word of God in an ever-changing world." ${ }^{753}$ Although the term contextualization was coined in theological circles in the early 1970s to designate a series of theological models attempting to make the gospel relevant to current culture, ${ }^{754}$ NT records point to principles of contextualization used by Jesus, as well as by Paul and other apostles. ${ }^{755}$ Accommodation, inculturation, and indigenization are some terms used as synonyms for contextualization. It means the process of making the gospel culturally relevant. ${ }^{756}$ As Bosch points out, the Christian

\footnotetext{
(2005): 346-52.

${ }^{753}$ See Stan May, "Ugly Americans or Ambassadors of Christ?," Evangelical Missions Quarterly 41, no. 3

${ }^{754}$ David J. Bosch, Transforming Mission: Paradigm Shifts in Theology of Mission (Maryknoll, NY: Orbis Books, 2004), 420-21.
}

${ }^{755}$ Müller points out that the Bible's revelation and inspiration process itself implies some sort of contextualization. That is, God spoke to the human being in a specific time, situation, and culture and communicated his message. For the author, the climax of this process was reached with the incarnation of Christ. The incarnate God (Heb 1:1-2) revealed, or "translated," contextualized certain aspects of divinity in human terms so that humanity could capture essential attributes of the transcendent God's character and personality. However, Müller highlights that the incarnation of Jesus was not a form of uncritical contextualization. Although Jesus adopted a Jewish lifestyle (Matt 17:24-27; Luke 4:15-16), at the same time he rejected certain customs of that culture (John 4:9; Mark 7:1-17) when these conflicted with the belief system and values that he defended as immutable. See Ekkehardt Müller, "Contextualization in the New Testament," in Misión y Contextualizacion: Llevar el Mensaje Bíblico a un Mundo Multicultural, ed. Gerald A. Klingbeil (Libertador Samartín, Entre Rios, Argentina, 2005), 17677. See more about contextualization in Jesus, Paul, and other apostles in Charles H. Kraft, "Culture, Worldview and Contextualization," in Perspectives on the World Christian Movement, ed. Ralph D. Winter and Steven C. Hawthorne (Pasadena, CA: William Carey Library, 2009), 404.

\footnotetext{
${ }^{756}$ Chigemezi-Nnadozie Wogu, "Constructs in Contexts: Models of Contextualizing Adventist Theology," International Bulletin of Mission Research 43, no. 8 (2018): 3, https://doi.org/10.1177\%2F2396939318754759.
} 
faith only exists as "translated" into a culture, ${ }^{757}$ and Kraft recalls that it is God's intention for Christianity to be reincarnated in every language throughout history. ${ }^{758}$

Contextualization aims to make Christianity relevant to solving problems that people face in the context in which they live. As Kraft argues, when adequately contextualized, Christianity becomes truly relevant and genuinely significant. ${ }^{759}$ However, to avoid syncretism, or the mixture of Christian premises with premises culturally incompatible with biblical Christianity, contextualization needs to be biblically appropriate. "Critical Contextualization”-A double exegesis of culture and Scripture has been proposed to minimize the risk of syncretism in the contextualization process. ${ }^{760}$

Although there are different contextualization models, ${ }^{761}$ in general, they can be grouped into two approaches. The first approach understands the Scriptures as a complete revelation of God, whose authority must take precedence over culture. In this sense, revelation is God sharing information about himself, his redemptive plan, and his will. The translation model of contextualization is an example of the first approach. The second approach understands Scripture as culturally conditioned and incomplete. Revelation is seen as a subjective finding or God's action in the world and cultures. Representing this second approach are feminist theology, black

\footnotetext{
${ }^{757}$ Bosch, Transforming Mission, 447.

${ }^{758}$ Kraft, "Culture, Worldview and Contextualization,” 404.

${ }^{759}$ Kraft, "Culture, Worldview and Contextualization," 405.

${ }^{760}$ See Paul G. Hiebert, “Critical Contextualization,” IBMR 11, no. 3 (1987): 10; Gordon R. Doss, “Too Far or Not Far Enough: Reaching out to Muslim People," Ministry, February 2005, 6-7; Wogu, "Constructs in

${ }^{761}$ In his study on models of contextualization, Stephen Bevans propones six models: 1) translation, 2) anthropological, 3) praxis, 4) synthetic, 5) transcendental, and 6) countercultural. Except for the translation model, these models see Scripture as culturally conditioned and incomplete. See Stephen B. Bevans, Models of Contextual Theology (New York: Orbis Books, 2002), 37-126. See more about contextualization models applied to the Adventist perspective in Wogu, "Constructs in Contexts."
} Contexts," 8. 
theology, liberation theology, and other contextual theologies related to postmodernism, pluralism, and relativism. The models of contextualization that use this approach replace the authority of Scripture with the authority of culture. ${ }^{762}$

The current section uses the narrative model centered on the concept of God's salvific purpose for all peoples, or the Missio Dei-also based on the first approach of contextualization exposed above. ${ }^{763}$ To that end, Paul's speech to the Athenian philosophers in the Areopagus will be analyzed. The intention is to detect signs of contextualization in Paul's discourse and verify their suitability for biblical instruction of the Nones.

\section{Acts 17:16-34}

Again, this section does not take a detailed approach to the pericope under study, but is limited to analyzing themes that demonstrate the contextualized focus of Paul's communication with the Athenian philosophers.

\section{To the Unknown God}

Extra-biblical sources confirm Luke's account of an altar dedicated to the "unknown god" in Athens (Acts 17:13), and provide information on how this worship was practiced in the city. The Greek author Laertius, from the third century AD, describes a tradition in his day, according to which Epimenides, a Cretan hero, poet, and prophet, had been called by Nicias to the city of Athens to advise local leaders on stopping a plague. According to the account, Epimenides

\footnotetext{
${ }^{762}$ See Müller, "Contextualization in the New Testament," 174-75. See also Donald A. Carson, The Gagging of God: Christianity Confronts Pluralism (Grand Rapids, MI: Zondervan, 1996), 540.

${ }^{763}$ For more on contextualization narrative models, see Sung Ik Kim, "Proclamation in Cross-Cultural Context: Missiological Implications of the Book of Daniel" (PhD diss., Andrews University, 2005); Tompkins, "God's Mission to the "Nations." For other contextualization models, see Wogu, "Constructs in Contexts," and Bosch, Transforming Mission.
} 
directed them to offer sacrifices to a god different from the multitude of gods that they had already petitioned without success. He advised them to place white and black sheep on the Hill of Mars early in the morning, follow the sheep, and mark where they lay, assuming that when they lay down, it was a sign that they were chosen and accepted by God for sacrifice. The Athenians built nameless altars at the marked locations and offered the sheep that lay down as sacrifices, and the plague ended. According to Laertius, altars with no engraved name could be seen in different parts of the region of Attica, serving as memorials to the end of the plague. ${ }^{764}$

While Laertius mentions altars without names, Pausanias and Philostratus allude to "altars of an unknown god," implying that they bear this inscription, confirming Luke's account. ${ }^{765}$ One of these altars was the focal point of Paul's contextualized message in his speech to the Athenian philosophers.

\section{Idolatry}

When Paul arrived in Athens as part of his second missionary journey, ${ }^{766}$ Luke says, the apostle's spirit revolted against the idolatry in force in the city (v. 16). As Richardson points out, men who reject the biblical God end up discovering, in frustration, that an infinite number of minor deities are needed to fill the space left by the true God. ${ }^{767}$ Paul began teaching in the synagogue for Jews (v. 17), but feared Gentiles, possibly because he saw them as accustomed to

${ }^{764}$ See Diogenes Laertius, Lives of Eminent Philosophers, Volume 1, trans. R. D. Hicks, Loeb Classical Library 184 (Cambridge, MA: Harvard University Press, 1925), 110. See also Aristotle, The Art of Rhetoric, trans. J. H. Freese, Loeb Classical Library 193 (Cambridge, MA: Harvard University Press, 2020), 17.10.

${ }^{765}$ See Pausanias, Description of Greece (New York: G. P. Putnam's Sons, 1918), 1:7; Philostratus, The Life of Apollonius of Tyana: The Epistles of Apollonius and the Treatise of Eusebius (New York: G. P. Putnam's Sons, 1921), 6:13.

${ }^{766}$ Bock, Acts, 1519.

${ }^{767}$ Don Richardson, Eternity in Their Hearts: Startling Evidence of Belief in the One True God in Hundreds of Cultures Throughout the World (Bloomington, MN: Bethany House, 2005), Kindle Locations 192-93. 
the city's idolatry. He also taught in the square every day, addressing Athenians in general. ${ }^{768}$ Luke says that Epicurean and Stoic philosophers contended with Paul in the square as he fought against idolatry and preached about Jesus and the resurrection (v. 18). They brought the apostle to the Areopagus, asking him to clarify his teachings, since the themes were foreign to them, and, as Luke points out, they liked new things (vv. 19-21).

\section{Stoicism and Epicureanism}

The philosophical school of Stoicism was founded by Cypriot Zeno (340-365 BC) and received its name because its members met in the stoa poikilē, or "painted colonnade," the marketplace in Athens where Zeno taught. ${ }^{769}$ The Stoics defended life under nature and placed great emphasis on the primacy of reason and individual human self-sufficiency. They were essentially pantheists, seeing the divine as the world's soul, and they also advocated freedom and equal rights among human beings. At its best, Stoicism advocated great moral seriousness and a high sense of duty. In their independent spirit, the Stoics quoted the proverb "I thank whatever gods may be for my unconquerable soul." 770

The Epicurean school was founded by Epicurus (340-370 BC) and presented pleasure as the primary purpose of life. For them, a tranquil life, free from pain and superstitious fears, including fear of death, was the most worthwhile to be lived. Epicureans did not deny gods'

\footnotetext{
${ }^{768}$ Richardson, Eternity in Their Hearts, Kindle Location 193.

${ }^{769}$ Bruce, Book of the Acts, Kindle Location 11510.

${ }^{770}$ Bruce, Book of the Acts, Kindle Locations 11531-32.
} 
existence, but saw them as having a distant and indifferent perspective on human life. ${ }^{771}$ They might be compared to today's secularist agnostics. ${ }^{772}$

Although the Stoics and Epicureans presented themselves as philosophical rivals, both groups agreed that Paul's message was irrational and a second-class philosophy. Some called Paul "a chatterbox" $" 773$ or an ignoramus who spoke of what he did not know. Others interpreted his mentions of Jesus and the resurrection as the personification of divinized healing and restoration powers. ${ }^{774}$ In short, Paul's audience of philosophers suffered from intellectual arrogance. $^{775}$

\section{Mission Based on Contextualization}

Paul's speech on the Areopagus needed to answer the questions of the philosophers, who accused him of being a preacher of strange gods for having fought idolatry and talked about Jesus and the resurrection in the town square (vv. 18-20). Paul realized that he must adapt his great themes to that environment of cross-cultural communication, making them attractive and understandable to his listeners. Bock points out that it is necessary to appreciate the apostle's ability to contextualize in this sense. ${ }^{776}$ The Areopagus, also called "The Society of the Hill of Mars," was where a group of learned Athenians met to discuss history, philosophy, and religion.

\footnotetext{
${ }^{771}$ Bruce, Book of the Acts, Kindle Locations 11537-43.

${ }^{772}$ Bock, Acts, 1643.

${ }^{773}$ Bock, Acts, 1645.

${ }^{774}$ See Frederic Henry Chase, The Credibility of the Book of the Acts of the Apostles (Eugene, OR: Wipf

${ }^{775}$ Chase, Credibility of the Book, 205-6.

${ }^{776}$ Bock, Acts, 1635.
} and Stock, 2005), 205-6. 
It was the same hill where, six centuries before, Epimenides had solved the plague problem in Athens, establishing the altars to the unknown god in the city. ${ }^{777}$

In this environment, Paul used some principles that facilitated communication. First, the apostle sought out an object familiar to the scholars to introduce an unfamiliar theme. He told them about the altar he had found in the middle of the countless pagan altars, with the inscription "To the unknown god." That example was a wedge, creating an opening to reach the hearts and minds of the listeners with the announcement of the creator God. Bruce points out that when the gospel was preached to a pagan audience, even one made up of educated people like the members of the Areopagus, it usually started with a statement about the living and true God. ${ }^{778}$ Having found a way to arouse his listeners' interest so that they were open to the profound truths that would follow, the apostle then began to introduce the creative God.

Richardson argues that by using an illustration to capture the listeners' attention for the message he would present, Paul was putting into practice what Jesus had promised him at the time of his call on the Damascus road. ${ }^{779}$ Jesus told the apostle that he would be sent to evangelize the Gentiles, "to open their eyes and turn them from darkness to light, and from the power of Satan to God, so that they may receive forgiveness of sins and a place among those who are sanctified by faith in me" (Acts 26:18). Richardson also says that for people to be freed from Satan's power and transported from darkness to light, their eyes must be opened to see the

\footnotetext{
${ }^{777}$ Richardson, Eternity in Their Hearts, Kindle Locations 230-31.

${ }^{778}$ Bruce, Book of the Acts, Kindle Locations 11598-99.

${ }^{779}$ Richardson, Eternity in Their Hearts, Kindle Locations 217.
} 
difference. ${ }^{780}$ The eye-opener Paul used here was the altar dedicated to the unknown god. Opening the eyes is a prerequisite for turning people from darkness to light.

Paul presented his theme in cautious words, once again showing his intention to contextualize his communication. He said, "People of Athens! I see that in every way you are very religious" (v. 22). These were polite words, coming from someone who hated idolatry. However, it was essential to build a bridge and not raise unnecessary barriers. ${ }^{781}$ While he was irritated by idolatry, he also understood that God's path should be paved gracefully. ${ }^{782}$ While the Greeks interpreted "very religious" as expressing pity, the Jews saw it as superstition. ${ }^{783}$ In any case, the expression was positive for the apostle's audience. Paul continued: "For as I walked around and looked carefully at your objects of worship, I even found an altar with this inscription: To an Unknown God" (v. 23). He could have expressed horror at the countless pagan altars, but he preferred to refer to "objects of worship." This avoided unnecessary communication barriers, emphasizing the positive and expressing value instead of defects. ${ }^{784}$ Bruce says that Paul wisely adapted his tone and approach to the listening audience, making the message relevant to them. ${ }^{785}$ For Bock, the tone of the apostle's speech was conciliatory with their culture. ${ }^{786}$ Alternatively, as Witherington says, Paul sought to create a bridge to reach pagan

\footnotetext{
${ }^{780}$ Richardson, Eternity in Their Hearts, Kindle Locations 218.

${ }^{781}$ Richardson, Eternity in Their Hearts, Kindle Locations 236-37.

${ }^{782}$ Bock, Acts, 1635.

${ }^{783}$ Bruce, Book of the Acts, Kindle Locations 11615-16.

${ }^{784}$ See Hubbard, The Book of Ruth, 38.

${ }^{785}$ Bruce, Book of the Acts, Kindle Locations 11603-4.

${ }^{786}$ Bock, Acts, 1637.
} 
culture with the gospel. ${ }^{787}$ White ponders that if Paul had made a direct attack on the gods and the great leaders of the city, he would not only have lost his audience, but risked the death sentence given to Socrates under similar circumstances. ${ }^{788}$

Next, Paul made the statement that, as Richardson states, had waited six centuries to be pronounced: "What therefore you worship as unknown, this I proclaim to you" (v. 23). ${ }^{789}$ Paul was responding to the philosophers who accused him of teaching about a strange god. According to the apostle's reasoning, $\Theta \varepsilon \omega$ (Theō), or the God he proclaimed, was represented on the altars of Epimenides, and therefore was not alien to the Athenians. God had already influenced the city's history, and, therefore, his proclamation in Athens was legitimate.

Then, in his contextualized communication, Paul used the principle of "continuous logic," which consisted of successive statements obeying a logical sequence, without leaving any space to develop his reasoning. This prevented the philosophers from interrupting him.

Richardson points out that the philosophical education rule determined that no space should be left in the logical development of discourse. Any stranger who claimed to have a proposition worthy of attention should follow this logic. ${ }^{790}$

The apostle managed to stand up to the severe scrutiny of the philosophers in most of his speech. After the testimony about Epimenides' altars, he went through the evidence of creation, and from there to the inconsistency of idolatry (vv. 24-29). Paul took the opportunity to bring the listeners' minds even closer by quoting parts of two poems by well-known scholars from his

\footnotetext{
${ }^{787}$ Witherington, Acts of the Apostles, 533-35.

${ }^{788}$ White, The Acts of the Apostles, 238, 243.

${ }^{789}$ Richardson, Eternity in Their Hearts, Kindle Location 239.

${ }^{790}$ Richardson, Eternity in Their Hearts, Kindle Locations 261-62.
} 
audience: “'In him, we live and move and have our being'; as even some of your poets have said, 'For we are indeed his offspring"' (v. 28). To make the speech attractive and understandable to his listeners, Paul alluded to Stoic and Epicurean principles and quoted from Greek poets instead of quoting the Hebrew Scriptures as he did in speeches to his countrymen. It was a strategy to facilitate contact. However, his arguments and even his use of poetic texts were intended to confirm biblical revelation. ${ }^{791}$ Polhill points out that every statement by Paul was rooted in OT thinking. ${ }^{792}$ On Paul's claim that we are a generation of God, Bruce ponders that the apostle was not thinking in a pantheistic sense, as many of his audience believed, but in the biblical sense of seeing the human being as created in God's image. ${ }^{793}$ In this sense, Paul emphasized the human responsibility to honor God as creator. For him, this honor was not rendered if the divine was visualized in the form of an image, exposing the listeners to idolatry's madness (v. 29). ${ }^{794}$

The use of direct quotes from Greek poetry shows that Paul knew the historical background of the altar dedicated to God in Athens under Epimenides' guidance. The first part of Paul's line "For we live in it, we move and exist" quotes Epimenides, and in Titus 1:12-13 Paul quotes the opening part of the same poem. ${ }^{795}$ The other part of Paul's quote, "because we are also a generation," is attributed to Aratus, a poet who wrote about God and the planets. ${ }^{796}$ In addition to quoting the Cretan poet, Paul called him a prophet, using the same term he commonly

\footnotetext{
${ }^{791}$ See Bruce, Book of the Acts, Kindle Locations 11606-7.

792 Polhill, Acts, 373.

${ }^{793}$ Bruce, Book of the Acts, Kindle Locations 11708-9.

${ }^{794}$ Bruce, Book of the Acts, Kindle Locations 11711-12.

${ }^{795}$ See Clement of Alexandria, "The Stromata or Miscellanies: Book 1," Early Christian Writings, http://www.earlychristianwritings.com/text/clement-stromata-book1.html; Encyclopaedia Britannica, s.v. "Epimenides," https://www.britannica.com/biography/Epimenides.

${ }^{796}$ See Aratus, "Phaenomena," Theoi Classical Texts Library, https://www.theoi.com/Text/AratusPhaenomena.html
} 
used for the Old and New Testament prophets. Members of the Areopagus society may have known Epimenides' story through the works of Plato and Aristotle, and must have been amazed that the apostle began his speech from a cross-cultural perspective. ${ }^{797}$

As Richardson observes, at that time, Paul came to a position where he could even identify Athenian idolatry as "ignorance" without losing his audience. ${ }^{798}$ The apostle concluded his logical sequence of reasoning by pointing out that the unique Creator God commanded humanity to repent because one day, everyone would be judged by a man whom he raised from the dead (vv. 30-31). Here, for the first time, there was an interruption in the logic of Paul's speech. He mentioned the resurrection of the man that God designated to judge the world, without first explaining how and why he had to die, and the philosophers reacted immediately. ${ }^{799}$ Luke says that some mocked Paul and others said that they would hear him again on the subject of the resurrection, and the apostle immediately withdrew (vv. 32-33).

Unfortunately, the scholars in Paul's audience were more concerned with his technique of communication than with the search for the truth. Forgetting the content of his speech, they condemned him for his technical failure, preventing him from continuing. However, Luke shows that some of the listeners believed and accepted Paul's instructions, among them a member of the Areopagus named Dionysius and a woman named Damaris. The name Dionysius derives from the Greek god whose theology contained a resurrection concept; perhaps familiarity with this

\footnotetext{
${ }^{797}$ See Richardson, Eternity in Their Hearts, Kindle Location 255.

${ }^{798}$ Richardson, Eternity in Their Hearts, Kindle Location 265-66.

799 The Greeks did not have a uniform position regarding the state of the dead. Positions on this issue fluctuated between belief in the complete extinction of the body and soul, belief in the afterlife in Hades, and belief in limited immortality of the soul instead of eternal immortality. See N. C. Croy, "Hellenistic Philosophies and the Preaching of Resurrection," Novum Testamentum 39 (1997): 21-39; Bock, Acts, 1674.
} 
concept led the scholar to accept Paul's exposition about the dead's resurrection. ${ }^{800}$ The tradition in the second century indicates that Dionysius later became the first bishop of Athens. ${ }^{801}$

Bruce points out that Paul's speech is a summary of how to introduce the gospel to a pagan culture. ${ }^{802}$ With the goal of making them abandon idols for God, the apostle dedicated most of his speech to the right knowledge of God. ${ }^{803}$ In this sense, the essential content of the speech is biblical, but the presentation is Hellenistic. ${ }^{804}$ Bock summarizes Paul's methodology in Athens by pointing out that he was directly engaged in their culture. For him, Paul shared the gospel in a generous but honest spirit of love. He was connected with their society, showing that both message and tone are important when sharing the gospel. ${ }^{805}$ This episode is an example of how to contextualize the methodology according to the needs of the audience while preserving the gospel principles, considering that the essential message of the gospel transcends culture. ${ }^{806}$

\section{Missiological Implications of Theological Contextualization to Nones}

As already described, Paul's primary audience on the Areopagus was the Stoic and Epicurean philosophers. The Stoics were open to spirituality based on a pantheistic view. They

${ }^{800}$ Richardson, Eternity in Their Hearts, Kindle Location 279-80.

${ }^{801}$ See Isho'Dad of Merv, Horae Semiticae no. X: The Commentaries of Isho'Dad of Merv (Cambridge, UK: Cambridge University Press, 1913), 28.

${ }^{802}$ Bruce, Book of the Acts, Kindle Locations 11733-34.

803 M. Dibelius, "Paul on the Areopagus," in Studies in the Acts of the Apostles (New York: Charles Scribner's Sons, 1956), 71.

${ }^{804}$ Bruce, Book of the Acts, Kindle Location 11739.

${ }^{805}$ Bock, Acts, 1680-81.

${ }^{806}$ See Silvano Barbosa Santos, "Revelation and Contextualization: A Seventh-day Adventist Approach," accessed September 2, 2020, https://www.academia.edu/11050512/Revelation_and_Contextualization_A_Seventh_day_Adventist_Approach. 
placed great emphasis on integration with nature, as well as human freedom and self-reliance. On the other hand, the Epicureans were more secularized, and, although they admitted the existence of gods, they saw them as distant and indifferent to humans. For them, pleasure was the center of life.

Many Brazilian and American Nones have some similarities to Paul's listeners. Over half (53 percent) of American Nones claim to believe in spiritual forces, but only 17 percent believe in God as described in the Bible. ${ }^{807}$ That is, this group, for the most part, does not have a clear vision of God as a person, seeing him as energy or an impersonal force. Additionally, 37 percent of American Nones and the majority of Brazilian Nones declare themselves spiritual, but not religious, ${ }^{808}$ meaning that they are open to spirituality and relationship with the transcendent, but in a fluid and existentialist way. ${ }^{809}$ In the language of Suede, they express a holistic, mystical, and metaphysical religiosity. ${ }^{810}$ They find it challenging to accept biblical parameters, and place human freedom and individuality at the center of devotion. ${ }^{811}$ Roof calls them a generation of seekers. ${ }^{812}$ This group of Nones can be compared to the Stoics of Paul's audience, mainly because of their vision of God's impersonality, freedom, individuality, and human centrality.

\footnotetext{
${ }^{807}$ Pew Research Center, "When Americans Say."

${ }^{808}$ See Fuller, Spiritual, but Not Religious, 2; Godinho, “A individualização da espiritualidade”; Novaes,

${ }^{809}$ See Bauman, Modernidade líquida, 8-46.

${ }^{810}$ Camurça, "O futuro das religiões no Brasil," 74.

811 See Miller, “Spiritual but Not Religious," 855.

${ }^{812}$ Roof, A Generation of Seekers, 33, 41.
} “Os jovens sem religião,” 321-30. 
On the other hand, 29 percent of American Nones declare themselves to be atheists or agnostics, while the proportion is about 5 percent in Brazil. ${ }^{813}$ Like the Epicureans, this is a secularized group, framed by a society that functions without dependence on supernatural concepts and moral presuppositions. For them, actions must be based on technical and instrumental assumptions, not on mysticism. ${ }^{814}$ Pierucci points out that the process of disenchantment of laws in democratic societies leads people to an autonomous posture in everyday decisions, excluding religion as a framework that directs their lives. ${ }^{815}$ This smaller portion of the Nones in the two cultures reflects the more rational and secular stance of the Epicureans. Therefore, the principles of contextualized communication Paul used in his speech to the Athenian philosophers could make mission work with the Brazilian and American Nones more effective.

\section{Summary of Principle 4}

In his speech to the Athenian philosophers, the apostle Paul presented the gospel in a cross-cultural context by following principles that facilitate communication. Contextualization of the message aims to preserve the biblical content and make it understandable and relevant to the listeners. The themes must be suitable for the audience and meet their needs. Additionally, familiar examples, a conciliatory tone, a sequentially logical exposition, and quotes from familiar poetic literature were some of the elements Paul used to reach the philosophers. Such elements can facilitate communication with the Nones today.

${ }^{813}$ Pew Research Center, "When Americans Say”; Instituto Brasileiro de Geografia e Estatística, "Características gerais da população, religião."

${ }^{814}$ See Wilson, “Aspects of Secularization,” 266-67.

${ }^{815}$ Pierucci, "Secularização em Max Weber," 43-73. 
It can also be said that, to a greater or lesser degree, the four principles for cross-cultural mission studied in this chapter are all present in Paul's speech to the Athenians. The hesed attitude is noted in the polite way Paul addressed specific topics, using a conciliatory tone. Although implicit, there is also a reference to the manifestation of God's saving power, insofar as the altar to the unknown God memorialized God saving the city from plague. Biblical instruction was central to the apostle's speech: he addressed God's uniqueness, creation, redemption, judgment, the nullity of idolatry, and the resurrection, among other biblical themes relevant in that context. Finally, Paul contextualized his speech to make the content relevant to Athenians, though when he slipped up in the logic of developing his reasoning, he ended up losing the listeners' attention. The four principles for cross-cultural mission presented above are indispensable and complementary, and can contribute to a useful and relevant mission among the Nones.

\section{Summary}

Through the analysis of biblical narratives involving the conversion of foreigners, the current chapter demonstrated four principles that are recommended for cross-cultural mission and applicable to work with the Nones. First, as a representative of God, the missionary must reveal God's character by manifesting a hesed attitude towards others, regardless of their professed religion, and culture. The aim is to get people to know God as the source of hesed manifested by the experience of genuine faith. Like the relationship between Naomi and Ruth, deep, disinterested, and at the same time intentional relationships, in the context of hesed faith and actions, can be useful in reaching those who declare themselves to be Nones.

Second, God's power, manifested in the form, place, and time that he sees fit, can be a decisive factor in converting people to the Christian faith. As seen in Naaman's story, a miracle 
should not be an end in itself, nor an isolated act. Instead, should be the culmination of God's action in the person's life, with positive responses according to the light received. In this sense, the manifestation of God's power, as the culmination of a process, can be an effective instrument for helping the Nones know and position themselves alongside the biblical God.

Third, biblical instruction plays a fundamental role in the conversion process, especially in cross-cultural missions. As seen in the narrative of the conversion of Cornelius, there is no stable and conscious conversion in the void. In this case, hesed action and the manifestation of God's saving power do not eliminate the need for biblical teaching, but make the interested person open to receive it. It is also clear that the seeking process is not enough. Cornelius only became a full Christian when, based on the biblical instruction he received, he entered into a personal commitment to the biblical God and salvation through Christ. God uses human instruments for this purpose because the testimony of disciples who have already experienced God's saving power has a strong influence on listeners. The narrative also demonstrates that Christ must be at the center of biblical instruction, and the themes must be tailored to the listeners' needs. Just as Peter's teaching was essential for converting the God-fearers, biblical instruction is essential for the conversion of the Nones, especially those classified as seekers. They are open to spiritual experience, and if biblical beliefs and practices are presented according to their needs and centered on Christ, they will bring meaning and benefits to these individuals. The spirituality they exercise will become complete and established on a foundation of biblical instruction.

Finally, the exposition of the gospel in a cross-cultural context needs to be contextualized and guided by principles that facilitate communication, like Paul's speech on the Areopagus in Athens. In order to preserve the biblical content and at the same time make the instruction 
understandable and relevant to listeners, Paul chose themes suitable for the audience, familiar examples, a conciliatory tone, a logical continuous exposure of themes, and quotes from poetic literature of their culture. Such elements can make communication with the Nones more significant today. These four principles are indispensable and complementary and can contribute to a compelling cross-cultural mission, constituting a biblical framework for mission to the Nones. 


\section{CHAPTER V}

\section{CULTURAL AND MISSIOLOGICAL IMPLICATIONS}

As seen in previous chapters, the Nones in Brazil and the United States reflect the modern and postmodern influences of contemporary secularism, being a product of the development of human thought. In the pre-modern period of "myth" 816 or "tribe," 817 religion was at the center of people's lives, and supernatural powers were believed to be the source of all knowledge, understanding, and existence. Tradition, authority, and values were rooted in and shaped by religion. During this period, it was believed that the truth could only be found in the priesthood or church. ${ }^{818}$

The Protestant Reformation inaugurated modern Christianity, beginning the "ontological period," 819 also called the "town" period. ${ }^{820}$ In this "thinking society" or "pre-industrial" phase, religion was systematized, organized, and institutionalized, still maintaining itself as a source of control, strength, and human identity. ${ }^{821}$ In this period, the truth was no longer seen as residing in (1963): 13-21.

${ }^{816}$ See Cornelis A. Van Peursen, "Man, and Reality—-the History of Human Thought," Student World no. 1

${ }^{817}$ Cox, The Secular City, 1-12.

${ }^{818}$ Jon Paulien, "The Post-Modern Acts of God," Scribd, November 18, 2004, https://www.scribd.com/document/7240142/The-Post-Modern-Acts-of-God.

${ }^{819}$ Peursen, "Man, and Reality,” 13-21.

${ }^{820}$ Cox, The Secular City, 1-12.

${ }^{821}$ Gottfried Oosterwal, "The Process of Secularization," in Meeting the Secular Mind: Some Adventist Perspectives, ed. Humberto M. R. Rasi and Fritz Guy (Berrien Springs, MI: Andrews University Press, 1985), 5253. 
the priests or at church, but in the Bible. The search for truth became an act of reason and logic through careful study of the Scriptures. The concept of Sola Scriptura, characteristic of the period, established the Bible as the only rule of faith and practice and the ultimate source and safeguard of the truth. ${ }^{822}$

At the end of the eighteenth century, with the arrival of the Enlightenment, a transition began from modern Christianity to modern secularism, which became the Western world's dominant worldview in the first decades of the twentieth century. Conservative Christianity was no longer the dominant force, and faith or belief in the supernatural was no longer a default. In this period, human reason became established as the center of existence; the truth was no longer found in the church or the Bible, but discovered through the Newtonian scientific process of careful observation and experimentation. Science would provide the truth and technology would provide the power to transform the world, giving human beings control over their environment and destiny. ${ }^{823}$ Cox calls this period "Technopolis," 824 while Peursen calls it the "period of the function," taking into account the tendency to classify all things according to their function, including religion. ${ }^{825}$ However, the two world wars, genocides, weapons of mass destruction, terrorism, and other evils enhanced by science and technology brought great disappointment, and humanity began to search for the truth in other directions.

In the second half of the twentieth century, the postmodernist worldview was established: that truth is not found in the church, the Bible, or science, but in relationships and storytelling.

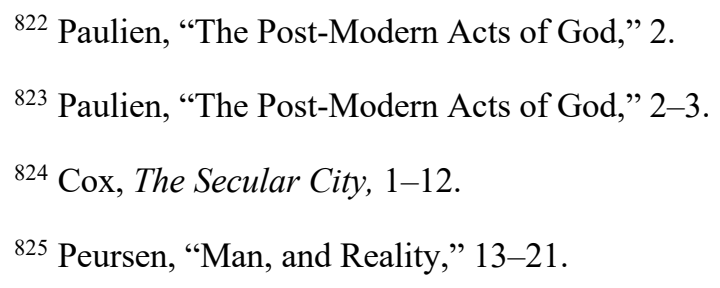


The postmodern trend is to rely on subjective emotions and experiences. The idea of one truth (with a capital T) was eliminated, and the possibility of a variety of truths was considered at the individual level. From this perspective, nobody has a complete understanding of the truth. Each person builds their own truth — the self-evident truth, for the benefit of the community as a whole, because "in the multitude of councils, there is wisdom." ${ }^{826}$ According to Paulien, in most countries in the West, people under thirty-five tend to be postmodern, while people sixty and over tend to be modern, opting for modern Christianity or modern secularism. Those between these two ages tend to be confused. ${ }^{827}$

Contemporary Nones, in their different representations, are a product of this process of change in human thought. The group reflects many characteristics of modern and postmodern secularism, making Christian mission among them challenging. In this chapter, eight topics will be discussed, some of which are considered critical and others as opportunities in the missional relationship with the Nones. The main characteristics of these topics will be summarized based on the discussion in the previous chapters, followed by suggestions of missiological and sociological principles for mission that, if applied, may fill gaps in each area.

\section{The Identity of God}

A majority of Nones profess to believe in God, but only a minority believe in God as described in the Bible. In the US, 53 percent of Nones believe in God as energy or spiritual strength, while only 17 percent believe in God as described in the Bible. ${ }^{828}$

\footnotetext{
${ }^{826}$ Paulien, "The Post-Modern Acts of God," 3.

${ }^{827}$ Paulien, "The Post-Modern Acts of God," 3.

${ }^{828}$ Pew Research Center, "When Americans Say."
} 
As a principle, an approach is proposed that emphasizes the personal, powerful, and loving character of the biblical God, according to the three examples below.

\section{Manifestation of God's Saving Power}

As seen in the story of Naaman described in the previous chapter, the manifestation of God's power, as the culmination of a process in which God is already working in the life of a seeker, with positive responses, can be a definitive step toward deciding for the Creator God. Thus, manifestations of God's saving power are proposed as a positive instrument. Although a divine miracle alone does not guarantee someone's conversion to the true God, as the culmination of a longer process, it can serve as a game-changer, resolve doubts, and provide certainty about the truth and uniqueness of the biblical God. God's power can manifest in different forms, such as healing, answer to prayer, release from the enemy's power, protection, and release from addictions, among others. ${ }^{829}$ However, one must maintain the centrality of the Gospel and the cross of Christ, never seeing the miracle as an end in itself. ${ }^{830}$ As in the cases of Naaman (2 Kgs 5:1-19), the widow of Sarepta (1 Kgs 17:8-24), and Rahab (Josh 2:1-21), experiencing God's saving power can be a decisive factor for the Nones to recognize his personal, loving, and powerful character.

\section{Manifestation of the "Energy of God"}

An approach that explores the NT's focus on the manifestation of God's energy, as described by the apostle Paul, can be effective in presenting the biblical God to the Nones. As already described, most of them see God as energy, and the biblical approach to the topic may be

\footnotetext{
${ }^{829}$ Lowe, Territorial Spirits and World Evangelisation, 134-41.

${ }^{830}$ Hiebert, "Spiritual Warfare and Worldview," 116.
} 
of interest to this group. In his books God's Energy and God Is Indestructible, Schwarz points out that Western translations of the NT do not refer to the energy of God when translating the

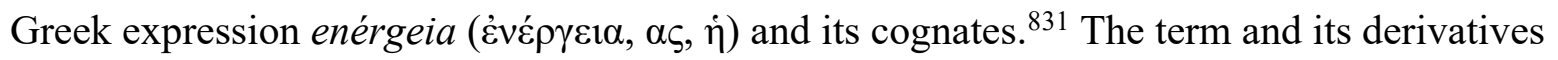
appear thirty-four times in the NT: ten times as a name (either enérgeia or energema), twentyone times as a verb (energeo), and three times as an adjective (energes). ${ }^{832}$ The English versions translate the expressions as "operation," "power," or "working” for the noun; "effectual," "powerful," or "strong" for the adjective; and "work," "perform," or even "do" for the verb. For Schwarz, the different meanings that appear in each text in the English translation obscure the fact that they all come from a homogeneous group of words, with profound theological implications. $^{833}$

The term enérgeia and its derivatives in the NT point to the divine action in executing the plan of salvation, which involves all aspects of Christian life, including personal growth,

${ }^{831}$ Schwarz points out that Western NT versions do not literally translate the term enérgeia and its derivatives, preferring other terms that do not always reach the original meaning of the expressions. He discusses the almost nonexistent use of the term energy until two hundred years ago, the alienation between the Greek East and the Latin West in terms of language, culture, spirituality, and theology, and the desire to avoid association with esoterism. He argues that energy was coined by Aristotle in the fourth century BC, as a technical term, to counter the meaning of dúnamis, which has a double meaning: power and possibility. In this sense, unlike dúnamis, energy does not refer to capacity but refers to the active exercise of capacity, including the results. In other words, energy turns potential into reality and points out the process and the results. Schwarz notes that, unlike Aristotle, who coined the term energy to counter and expand the sense of power, many groups in Western Christianity have chosen the word power to give meaning to the term energy, impoverishing the term's nature. He still says that it took about two hundred years in the NT period for the term enérgeia to become widespread in everyday use, like the expression energy in the Western context today. Much of the original meaning of the expression was preserved, especially by Paul, but the apostle singles out the expression exclusively for supernatural agents: God and Satan, never human beings. That is, God energizes his disciples, and Satan energizes his followers, but theologically speaking, no human being energizes another person. Finally, Schwarz mentions that, because these expressions do not appear in Western biblical versions, the main works of systematic and practical theology also exclude the concept of God's energy from Christian theology. According to him, only the Greek version used in the Greek Evangelical Church faithfully maintained the literal meaning of the terms. See Christian A. Schwarz, God's Energy: Reclaiming a New Testament Reality, Energy Trilogy 1 (Emmelsbüll, Germany: NCD Media, 2020), 29-65, Apple Books.

${ }^{832}$ See Matt 14:2; Mark 4:14; Rom 7:5; 1 Cor 12:6, 10, 11; 16:9; 2 Cor 1:6; 4:12; Gal 2:8; 3:5; 5:6; Eph 1:11, 19, 20; 2:2; 3:7, 20; 4:16; Phil 2:13; 3:21; Col 1:21; 2:12; 2 Thess 2:7, 9, 11; Phlm 1:6; Heb 4:12; Jas 5:16.

${ }^{833}$ Christian A. Schwarz, God Is Indestructible: 12 Responses to the Relevance Crisis of Christianity (Emmelsbüll, Germany: NCD Media, 2020), 941, Apple Books. 
mission, spiritual gifts, prayer, unity in diversity, leadership, church development, suffering, the Scriptures, Satan, predestination, sin, grace, and faith, among others. ${ }^{834}$ Schwarz notes that the suppression of God's energy in translations prevents the reader from perceiving the divine effort to move the reality of time and space to communicate his power to humans in the fulfillment of the plan of salvation. ${ }^{835}$ For him, the theme of God's energy occupies a prominent place in the NT, addressing critical theological issues related to redemption, the fulfillment of the mission, and the practice of the Christian life. Through divine energy, humans participate in the divine nature without becoming part of God's essence. ${ }^{836}$

Schwarz describes several benefits of the paradigm of the energy of God. First, the transcendent God also becomes immanent, making a difference in all spheres of human life, not just in the religious sphere. The presence of God's energy gives human beings an intrinsic motivation for life and especially for the fulfillment of the Christian mission: they become instruments for the fulfillment of God's purposes. In that sense, divine energy is given to be shared with others. Another benefit is synergy or cooperation between God and the human agent. The human will remain, but the divine sanctifies it so that human acts become the simple realization of God's will. Schwarz also points out that the energization provided by divine action results in spiritual maturity, as it does not eliminate adversity, but guarantees a person the supernatural strength to deal with it. ${ }^{837}$

\footnotetext{
${ }^{834}$ Schwarz, God's Energy, 284-85.

${ }^{835}$ Schwarz, God Is Indestructible, 967.

${ }^{836}$ Schwarz, God Is Indestructible, 907.

${ }^{837}$ Schwarz, God Is Indestructible, 1086-1146.
} 
Although the expression "God is energy" does not appear in the Bible, there is much evidence that the creator God is present in his energy, intervening in favor of human salvation. God's energy, described in the NT, points to God himself and is applied to the trinity as a whole. Exceptions appear in 2 Thess 2:9 and Eph 2:2, where the term applies to Satan. ${ }^{838}$ God's energy is not a tool or force that God created to give to human beings, but a way of describing the presence of God and testifying to the person of God. The theme points to the transpersonal dimension of God. He is a person, no less than a person, and at the same time, more than a person. ${ }^{839}$ Schwarz points out that the two extremes are unbiblical views of God: perceiving God as only personal is as incomplete as perceiving him as only impersonal, or only as energy. ${ }^{840}$ Schwarz argues that the biblical view of God's transpersonal dimension can be used as a bridge for dialogue with non-Christian religions regarding spiritual experiences. ${ }^{841}$ Through this dialogue, he writes, they may discover that there is a loving and active God behind the experienced energy, who can be found through prayer. ${ }^{842}$

Following the above reasoning, it can be said that focusing on the energy of God, as presented in the NT, is a way of describing God in a language that makes sense to the Nones. A purely rational and cognitive approach that neglects the category of God's energy may be perceived as cold and distant by this group. ${ }^{843}$ The biblical focus on a personal God who

\footnotetext{
${ }^{838}$ See Gerhard Kittel, ed., Theologisches Wörterbuch zum Neuen Testament (Stuttgart, Germany: W. Kohlhammer, 1935), 2:649.

${ }^{839}$ Schwarz, God's Energy, 301.

${ }^{840}$ Schwarz, God Is Indestructible, 1164-65.

${ }^{841}$ Schwarz, God's Energy, 303.

${ }^{842}$ Schwarz, God Is Indestructible, 1274.

${ }^{843}$ See Schwarz, God's Energy, 30.
} 
becomes known and manifests in his energy will also help clarify God's identity for the Nones. According to the Bible, God is a person and not just an energy or a force. His energy is a manifestation of his person acting for human salvation. ${ }^{844}$ Both dimensions of God, the personal and the transpersonal, are present in the Scriptures, and they harmonize.

\section{Jesus as the Perfect Revelation of God}

One of Jesus' most compelling biblical statements is found in John 10:30, "The Father and I are one." On another occasion, he contested Philip's request to show the Father to him and his fellow disciples, saying, "Whoever sees me sees the Father" (John 14:9). Through these texts, Jesus was not only defending his divine origin, showing that he was the Messiah announced by Bible prophecy, but also claiming to be the perfect revelation of God. As Keener states, the neuter "one" suggests a unity of purpose and not a personal identity. In other words, Jesus did not mean that he was God the Father, but that he came into the world as the divine Messiah to fulfill the saving plan, revealing the character of God the Father and carrying out his will. ${ }^{845}$ Following the same reasoning, Brodie argues that the Jews' attempt to stone Jesus for blasphemy after hearing his declaration of unity with the Father was a sign that they understood Jesus as declaring himself to be divine, or making himself equal to God (vv. 31, 33). ${ }^{846}$ They had previously accused Jesus of blasphemy in a similar context, saying that by declaring himself the Son of God, Jesus was making himself equal with God (5:18).

\footnotetext{
${ }^{844}$ See Schwarz, God`s Energy, 301-3.

${ }^{845}$ Craig S. Keener, The Gospel of John: A Commentary (Grand Rapids, MI: Baker Academic, 2003), $1: 826$.

${ }^{846}$ Thomas L. Brodie, The Gospel According to John: A Literary and Theological Commentary (New York: Oxford University Press, 1993), 377.
} 
The context of Jesus' speeches regarding his unity with the Father shows that his intention was more than presenting himself as the expected Messiah. He also wanted to show that he fulfilled God's mission and purpose by carrying out the plan of salvation. His oneness with his Father was manifested in his divine character, and also in his saving character. In this sense, each word spoken by Christ, each miracle he performed, and even his lifestyle revealed the personal, loving, and powerful character of God in the service of human salvation. ${ }^{847}$

The biblical emphasis on Jesus as God's perfect revelation is made even more evident in Hebrews 1: 3. In the text, the inspired author calls Jesus “The reflection of God's glory." As sinners, human beings cannot see God personally and contemplate His glory, but, veiled in the humanity of Christ, God's glory is revealed to humanity. In other words, the human being can see God's glory and understand His character through Christ. ${ }^{848}$ The author also says that Jesus is "the express image of His person." "Express image" is the translation of the Greek word

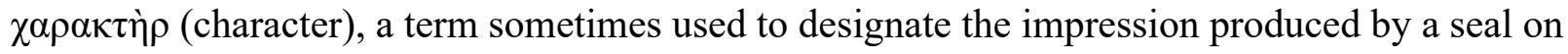
the wax or the representation stamped on a coin. ${ }^{849}$ Therefore, the biblical author is saying that Jesus resembles God perfectly, and if we want to see God, we must see Jesus, for the father is seen in the son. ${ }^{850}$

By sympathizing with the crowds and healing them (Matt 14:14), by evangelizing to the poor, by freeing the captives and the oppressed (Luke 4:18-19), and finally by giving his life to

\footnotetext{
${ }^{847}$ See Herman N. Ridderbos, The Gospel of John: A Theological Commentary (Grand Rapids, MI: Eerdmans, 1997), 371-72.

${ }^{848}$ Seventh-day Adventist College Presidents, Education: Sabbat School Bible Study Guide (Silver Springs, MD: Pacific Press, 2020), 39.

${ }^{849}$ See Seventh-day Adventist College Presidents, Education, 39.

${ }^{850}$ See Seventh-day Adventist College Presidents, Education, 39, 40.
} 
save sinners, Jesus revealed the character of God. Therefore, Jesus' ministry can be a positive instrument to introduce the Nones to the biblical God. The attributes of Jesus-humility, authority, sacrifice in favor of humanity, power, justice — can also help the Nones come to know the personal character of God.

\section{The Bible as the Source of Truth}

Under the influence of postmodernity, the Nones tend to relativize the content of faith, to reject the concept of absolute truth, and to reduce truth to a personal concept. Rejecting overarching stories (metanarratives), they see storytelling at the local level as a source of truth. ${ }^{851}$ Therefore, it is proposed that biblical themes be presented to Nones through the storytelling principle and not as systematic theology. This approach is in line with the way the Bible was written: as a collection of stories. Storytelling can arouse the Nones' interest in the themes presented, and it will also facilitate understanding by following their thought pattern. ${ }^{852}$

It is also proposed that biblical instruction to the Nones follow the principle of adequacy: in other words, it should meet the Nones' needs through pertinent and contextualized themes, as demonstrated by Peter's rhetoric in his speech to the God-fearers (Acts 10). Paulien emphasizes that it is essential to allow listeners to express the needs they feel they have, rather than setting an agenda based on what the speaker thinks they need. Only then is it possible to meet them with the Gospel. ${ }^{853}$

\footnotetext{
${ }^{851}$ See Kleber de Oliveira Gonçalves, "Witnessing to Christ in a Secular, Post-Christian, Postmodern Context," in Revisiting Postmodernism: An Old Debate on a New Era, ed. Bruce L. Bauer and Kleber de Oliveira Gonçalves (Benton Harbor, MI: Patterson, 2012), 135-38.

${ }^{852}$ See Paulien, "The Post-Modern Acts of God," 5.

${ }^{853}$ Paulien, "The Post-Modern Acts of God," 6.
} 
A portion of the Nones consider themselves spiritual seekers who are searching for meaning in life, similar to the God-fearers in the NT. ${ }^{854}$ However, as seen in Cornelius' conversion narrative, this attitude is not enough for a stable conversion. ${ }^{855}$ The Nones have a sense of brokenness, as well as a deep need for inner healing, ${ }^{856}$

It is proposed that the exposition of biblical themes obey the relational-application principle, so that the Nones understand these themes as benefiting them in their individual daily lives. Also, it is proposed that the principle of the centrality of Christ be followed. Christ is the great physician of the soul, capable of meeting human beings' deepest needs ${ }^{857}$ Furthermore, as Stackhouse says, presentation of Christ as the savior of humanity from the yoke of condemnation is attractive to this group, due to their disgust at oppressive leaders. In this case, Christ is seen as the One who liberates and not as one who subdues, making the message positive for the Nones' mindset. ${ }^{858}$

The postmodern ability of the Nones to be inclusive and tolerate opposites resembles Hebrew logic. Unlike Greek logic, which saw the opposite of truth as falsehood, Hebrew logic saw the contrast of ideas not in terms of true and false, but in terms of a tension between two opposite poles, ${ }^{859}$ Thus, it is proposed to use the Hebrew logic of tension between poles in study with the Nones. Themes that exemplify this tension, such as Christ being both 100 percent divine

\footnotetext{
${ }^{854}$ Roof, A Generation of Seekers, 8.

${ }^{855}$ See Bock, Acts, 1193.

${ }^{856}$ See Paulien, “The Post-Modern Acts of God," 4.

${ }^{857}$ See Hodgkin, Christ in All the Scriptures; Chapell, Christ-Centered Preaching, 247-85; Kaiser,

858 John G. Stackhouse Jr., "Postmodern Evangelism: Sharing the Gospel as a Nonviolent Metanarrative," in Revisiting Postmodernism: An Old Debate on a New Era, ed. Bruce Bauer and Kleber de Oliveira Gonçalves (Benton Harbor, MI: Patterson, 2013), 37.

${ }^{859}$ Paulien, "The Post-Modern Acts of God," 5.
} Messiah in the Old Testament, 232-33. 
and 100 percent human, the relationship between faith and works, the present and future aspects of salvation, and the defeat and victory of the cross, among others, can be an attraction for them. ${ }^{860}$

Many of the Nones inhabit the so-called "contemporary secular," defended by Asad, maintaining the modern and postmodern habits of freedom, independence, relativism, syncretism, and inclusivism without giving up subjective spirituality. ${ }^{861}$ They analyze religious themes from a functional point of view and not from a logical-rational point of view, and so these Nones' acceptance or rejection of themes is determined by the benefits received. ${ }^{862}$ Therefore, it is proposed that biblical themes not be presented in metaphysical form, as cognitive facts and mainly rational truths. Instead, themes should be presented according to the functional principle, in such a way that the Nones can see meaning in them. Oosterwal points out that this

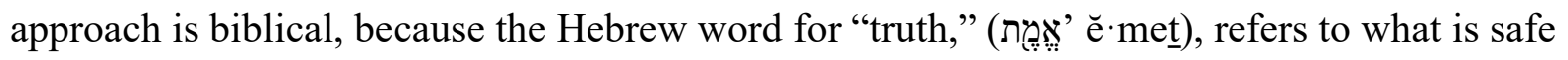
and reliable rather than something rationally elaborated and placed in a system. It is a related process in which the whole participates, instead of just a proposition at the cognitive level. ${ }^{863}$ In this perspective, Rodriguez notes that one of the main characteristics of biblical religion is its impact on every aspect of human life. For him, biblical precepts are a way of life and not merely a way of thinking or a set of concepts and beliefs. ${ }^{864}$ In a study of God, for example, instead of trying to expose the attributes that prove his divinity and show who he is through rational

\footnotetext{
${ }^{860}$ Paulien, "The Post-Modern Acts of God," 5.

${ }^{861}$ Asad, Formations of the Secular, 1, 15.

${ }^{862}$ Patriota, "O show da fé," 82.

${ }^{863}$ Oosterwal, "The Process of Secularization," 51.

864 Ángel Manuel Rodriguez, "Oneness on the Church in Message and Mission: Its Ground," in Message, Mission, and Unity of the Church, ed. Ángel Manuel Rodriguez (Silver Springs, MD: Biblical Research Institute,
} 2013), 252. 
abstraction, it is best to focus on the experience and benefits of the relationship with God-in other words, to make God known by his acts and by his saving power, which can be experienced with great benefits. ${ }^{865}$ The idea is to make the Gospel a life experience so that contemporary Nones can feel and live the benefits of faith. In a study on the Sabbath, rather than cognitively proving that this is the biblical day of worship, the best way to reach these Nones is to show them the benefits of Sabbath-keeping. Pointing to the Sabbath as a blessing planned by God to manage stress, family distance, the rush of contemporary life, and even the need for greater intimacy with Jesus can make it desirable and attractive for this group.

Considering that contemporary Nones reject the fragmentation of knowledge and experience proposed by modernism and divide each aspect of human life into specializations, ${ }^{866}$ the integrative principle is proposed as a primary approach to working with the group. This approach includes a holistic view of life, integrating body, mind, and spirit. Biblical themes that point to a holistic view of life can be attractive to the Nones. In this sense, it is useful to explore the way fundamental themes of the Old Testament such as the Sabbath, Jubilee, Shalom, and Messianic hope are developed in the New Testament, showing God's direction in establishing holism and human needs. Gonçalves also suggests that community members' real presence through an incarnational ministry and relationships that produce trust is an integrational approach par excellence. ${ }^{867}$

Finally, Berger writes that because the Nones are affected by religious pluralism, they have varied experiences concerning faith content. On the one hand, they may reject religious

\footnotetext{
${ }^{865}$ Oosterwal, "The Process of Secularization," 51.

${ }^{866}$ Harry L. Poe, Christian Witness in a Postmodern World (Nashville, TN: Abingdon, 2001), 28.

${ }^{867}$ Gonçalves, "Witnessing to Christ," 133.
} 
dogmatism; on the other, they may experience a great deal of insecurity in the face of a confusing world full of interpretive possibilities. Those with this second perspective may seek support in communities free of cognitive disagreement, offering certainty through sound doctrines and codes of behavior. ${ }^{868}$

Therefore, the biblical content is missional in nature, and if properly used, will reach people, including the Nones, in the context where they live. As N. T. Wright points out, the Bible was not written for the primary purpose of giving people a coherent set of ideas, although it does. Instead, Scripture was produced to support and direct the missional life of the church. Wright observes that the NT text sustained, conducted, and energized the early church while it fulfilled the mission of revealing God's love and power to the world to be saved. ${ }^{869}$

\section{Institutionalized Religion}

The Nones in both Brazil and the United States show an attitude of disgust toward institutionalized religion, ${ }^{870}$ but some of them are open to spirituality on an individual and subjective level, guided by personal choices, without institutional bias. These are the so-called unchurched or "spiritual, but not religious." ${ }^{871}$ It is proposed that the missiological approach to this group follow the "salt model of evangelism" instead of the "fortress model of evangelism," as well as the principle of small relational groups. In the fortress model, people are invited to enter the church to learn about biblical themes and be evangelized. Due to the prejudice of the

${ }^{868}$ Berger and Luckmann, Modernity, Pluralism, 54.

${ }^{869}$ N. T. Wright, "Reading the New Testament Missionally," in Reading the Bible Missionally, ed. Michael W. Goheen (Grand Rapids, MI: Eerdmans, 2016), 176.

${ }^{870}$ Weber, The Protestant Ethic, 105-12; Wilson, Religion in Secular Society, 14; Luckmann, The Invisible Religion, 26-30; Wallis, Elementary Forms, 57-60.

${ }^{871}$ See Taylor, A Secular Age, 512-31, 538; Taylor, Ethics of Authenticity, 25, 26, 36, 39, 46, 50, 65, 74, 82; Taylor, "Características e interfaces." 
Nones, this approach will have little success in attracting them. In the salt model, church members, as disciples, go into the world where people live and, like salt, make the environment better by their presence. It is an incarnational model. Just as salt mixes with food and imparts flavor to it, church members can positively influence their environment at work, at school, and with family members and neighbors. ${ }^{872}$ Further, Schnabel points out that just as salt is an indispensable ingredient for imparting flavor to food, the testimony of Christ's disciples is irreplaceable as a transmitter of meaning to the lives of those around them. He emphasizes that, just as salt exists only for food, disciples do not live for their own benefit, but to bless and save others. ${ }^{873}$ The disciple's life is focused on productive interaction using the hesed action, eliminating barriers, breaking down prejudices, and demonstrating the Gospel through life experience in practice. Despite their suspicion of traditional institutions and the Bible, the Nones are open to personal faith and practice, as well as spiritual discussions with those who know God.

Pondering the impact of personal testimony on the mission, Moltmann points out that the church does not have a mission: the church is its mission for us, Christ's disciples. At the same time, it is the mission that creates the church. ${ }^{874}$ In his book Revolution, Barna describes "revolutionary Christians" who today seek to live a lifestyle similar to that of first-century Christianity, marked by a commitment to the Bible, and manifested by faithfulness, kindness, love, generosity, and simplicity, among other traits. Barna describes this group as interdenominational, formed by pastors, church leaders, and ordinary members, many who are regular

\footnotetext{
${ }^{872}$ See Paulien, "The Post-Modern Acts of God," 6.

${ }^{873}$ Eckhard J. Schnabel, Early Christian Mission: Jesus and the Twelve (Downers Grove, IL: InterVarsity Press, 2004), 314.

${ }^{874}$ Jürgen Moltmann, The Church in the Power of the Spirit (New York: Harper and Row, 1977), 10.
} 
churchgoers and others who attend less often. Their common denominator is commitment to the Bible, faithfulness to God, and service to others. For Barna, this group's way of life is the only viable antidote to contemporary Americans' dysfunctional lifestyle, marked by unsustainable moral standards, dysfunctional relationships, material excesses, abuse of power, and inappropriate use of talents and knowledge ${ }^{875}$ Following the previous reasoning, such revolutionary Christians can be a positive influence on the Nones by expressing the hesed attitude as a lifestyle, following an incarnational approach, and practicing evangelism guided by friendship.

The principle of small relational groups is also proposed as a recommended approach for working with the Nones. As already described in the previous section, this approach can be useful because groups meet in people's homes, instead of in churches, and involve the participation of friends and family, which is also a barrier against prejudice. An environment of prayer and meeting people's needs can help gain the participants' interest and trust. Following this principle, the study topics must follow a relational format, applied to people's practical lives. ${ }^{876}$ In addition, the environment of a small relational group is constructed to make people feel accepted and included. A place of acceptance, where people have the opportunity to open their hearts without being judged, is an attraction for the Nones. As already seen, they are tolerant of differences and inclusive, and as J. E. White explains, mission to the Nones needs to be inclusive and grounded in the culture of acceptance. However, he argues that acceptance does

\footnotetext{
${ }^{875}$ George Barna, Revolution (Wheaton, IL: Tyndale House, 2005), 12.

${ }^{876}$ See Oosterwal, "The Process of Secularization," 60.
} 
not mean affirmation of behaviors, but a welcoming embrace, an expression of love and affection, creating an atmosphere conducive to taking people to the cross. ${ }^{877}$

Finally, the principle of approaching Christian identity is proposed. In her study of how to reach and retain Nones between 18 and 25 years old - the age range that represents the highest percentage of Nones (Figure 2) — Beth Seversen proposes this as a sound principle. ${ }^{878}$ The proposal is coherent, primarily because young adults are still defining their values and choices in the professional, sentimental, and spiritual realms. Their lives are guided by personal choices and no longer by parents' decisions. For this reason, living with a Christian identity, through relationships with people who testify positively to the gospel, can awaken in them the desire to belong to the Christian community. Lindório calls this experience "martyrical church," or evangelism by revealing the character of Christ through life experience. ${ }^{879}$ Another factor relevant to young adult Nones is their proactive characteristic of searching for self-realization. Robert Wuthnow associated this group with the term bricolage. ${ }^{880}$ Based on the studies of French anthropologist Claude Levi Strauss, the term alludes to doing small jobs and activities without the use of professional services: that is, doing the work for oneself, using the tools, materials, and instructions available_ “ "a construction improvised from multiple sources." 881 Young adults tend to build their religiosity from their own experiences and the products

${ }^{877}$ White, Rise of the Nones, 154.

${ }^{878}$ Beth Seversen, Not Done Yet: Reaching and Keeping Unchurched Emerging Adults (Downers Grove, IL: InterVarsity Press, 2020), 22-23.

${ }^{879}$ Ronal Lindório, “A teologia Bíblica da contextualização,” in Contextualização missionária: Desafios, questões e diretrizes, ed. Barbara Helen Burns (São Paulo, SP: Vida Nova), 8.

${ }^{880}$ Wuthnow, After the Baby Boomers, 15.

881 Wuthnow, After the Baby Boomers, 14. 
accessible to them — something like spiritual tinkering, in the language of Seversen. ${ }^{882}$ According to Seversen, it is necessary to allow them to "try on" and "try out" identity by participating and contributing to spaces. This type of participation and contribution leads them to experience the Christian identity before deciding whether it is desirable. ${ }^{883}$ Another concept that helps to understand young adults' need for experimentation is that of the "social moratorium." Coined by the Englishman Karl Mannheim in the late 1950s, it expressed that youth was a particular time to experiment, develop creativity, and define values. ${ }^{884}$ Following this reasoning, the Nones of this age group should have the opportunity to explore and experiment with Christian identity through belonging to communities - prayer programs, small groups, social service groups — which creates a positive opportunity to decide for Christian faith.

Considering the Nones' rejection of religious institutions and their search for an individualized faith, naturally, questions arise about the role of the local church and whether it is necessary in the process of religious formation. From this perspective, Spencer predicted that a day would come when the only worship service would be one in which each person practiced freely within themselves. ${ }^{885}$ In his analysis of the influence of secularization on religious manifestation, Durkheim, in turn, predicted that religion would remain not only through the element of faith, an individual attitude, but also through the element of worship, a more collective perspective. ${ }^{886}$ However, he added that religion would first respond to individual

\footnotetext{
${ }^{882}$ See Seversen, Not Done Yet, 22.

${ }^{883}$ Seversen, Not Done Yet, 23.

${ }^{884}$ Luís Antonio Groppo, "O funcionalismo e a tese da moratória social na análise das rebeldias juvenis," Estudos de Sociologia 14, no. 26 (2009): 41, 46.

${ }^{885}$ Spencer, Principles of Sociology, chap. 16, pt. VI.

${ }^{886}$ Durkheim, Elementary Forms, 429.
} 
aspirations and only secondarily to collective aspirations. Thus, the church would remain, but with less control over adherents, due to relativizing the belief system. ${ }^{887}$

Barna's position on the relevance of the local church in his book Revolution seems dubious. On the one hand, he says that the Christian church has a legacy of more than two thousand years and that there is nothing wrong with being involved with the local church. ${ }^{888} \mathrm{He}$ also says that revolution has nothing to do with eliminating the local congregation. On the other hand, he says that most church members in North America do not lead the lifestyle of a revolutionary Christian, and to achieve it, they may have to stop attending church. ${ }^{889}$ However, the book's more in-depth analysis shows that Barna does not consider the local congregation to be unnecessary or even an impediment to building the type of revolutionary Christians needed to face contemporary society's challenges.

Barna's central emphasis is that being a church member and participating in worship services alone do not make a person a spiritually committed, faithful, and revolutionary Christian. More is needed. Revolutionary Christians are zealous and have an intimate relationship with God, know the Bible deeply, represent the love of Jesus in living with others, and deal with life's decisions and challenges according to God's will. They challenge local churches to target their members' revolutionary experience and challenge each believer with the idea that the Christian call is not to go to church, but to be the church. ${ }^{890}$

\footnotetext{
${ }^{887}$ Durkheim, Elementary Forms, 175.

${ }^{888}$ Barna, Revolution, 35, 36, 38.

${ }^{889}$ Barna, Revolution, 115, 117.

${ }^{890}$ Barna, Revolution, 14, 15, 32-34.
} 
Luckmann argues that private religiosity can be supported by a person, by family, or by friends ${ }^{891}$ However, he recognizes that it is only within the religious community, the "ecclesia," that conversion can be effectively maintained ${ }^{892}$ The remedy for modern pluralism, and for the consequent crisis of meaning, is rescuing the idea of community ${ }^{893}$

Most of the above authors recognize that the local congregation has a primary role in the spiritual formation and maintenance of believers' faith, which is in line with the author of Hebrews' warning to church members that they should not fail to congregate. The inspired author implies that spiritual growth, victory over sin, and faith maintenance are related to individual experience with God and worship in the faith community (Heb 10:19-39). About a third of American Nones also think it is essential to belong to a community of people who share values and beliefs. ${ }^{894}$ As already seen, when working with the Nones, local congregations should prepare members to take a personal approach through the principles of friendship evangelism, the salt model of evangelism, the hesed attitude, and small relational groups, following the experience of Christ himself. However, this approach does not replace the role of the congregation, and in due time, when they overcome their prejudice, the Nones will join the collective worship provided by the church.

\footnotetext{
${ }^{891}$ Luckmann, The Invisible Religion, 106.

${ }^{892}$ Berger and Luckmann, Social Construction of Reality, 177-78.

${ }^{893}$ Luckmann, The Invisible Religion, 106.

${ }^{894}$ See Pew Research Center, "Nones on the Rise."
} 


\section{Need for Relationships and Community}

Many of the Nones, affected by postmodern influence, believe that the truth is not found in the church, in the Bible, or through logical cognition or science, but in relationships. ${ }^{895}$ Furthermore, the Nones tend to place a high value on humility, honesty, and authenticity in personal relationships. ${ }^{896}$ And since the Nones value community life, they value groups highly. ${ }^{897}$ Therefore, the principle of friendship evangelism is proposed for working with the Nones. Oosterwal observes that the evangelism of friendship with church members who use the gifts of the Spirit in everyday situations can be useful with the Nones, as they hold relationships in high regard ${ }^{898}$ Oosterwal writes that God supplies his disciples with gifts and abilities to witness in the places where they live, including their neighborhoods, workplaces, and families, based on friendship and companionship. ${ }^{899}$

The principle of "Otherness," as suggested at the June 2010 Edinburgh world conference, is also proposed, aimed at evangelizing people influenced by postmodernism, ${ }^{900}$ which includes a portion of the Nones. Due to alienation and loneliness arising from modernism, postmodernism emphasizes the importance of relationships and community life. Thus, mission with the Nones

\footnotetext{
895 They say the truth is found in relationships and storytelling. The second aspect will be addressed in a following section. See Paulien, "The Post-Modern Acts of God," 3.

${ }^{896}$ Paulien, "The Post-Modern Acts of God," 4.

${ }^{897}$ Paulien, "The Post-Modern Acts of God," 4-5.

${ }^{898}$ Oosterwal, "The Process of Secularization,” 60.

${ }^{899}$ Oosterwal, "The Process of Secularization," 60.

900 The Edinburgh world conference, held in June 2010, celebrated the centenary of the same meeting held in the city in 1910. On that occasion, representatives of Christianity from the whole world gathered to study and propose ways of testifying for Christianity in the twenty-first century. See more information at http://www.edinburgh2010.org.
} 
can explore the biblical worldview about the other. ${ }^{901}$ As Gonçalves attests, the Bible shows that human beings exist in relationships with God, nature, themselves, and others. In this sense, Gonçalves proposes that biblical themes emphasizing the restoration of our relationships with God and our neighbors can be bridges of access to postmoderns. Jesus' teachings about who is our neighbor, how to relate to enemies, and the church as a community of faith bringing together people from all cultures and races are some indicated topics related to this issue. ${ }^{902}$

In the context of evangelism through friendship and witnessing based on relationships, training for church members is essential. The emphasis on the need for training laypeople for the ministry points to the "seminar model," instead of the mobilization "volunteer model." The volunteer model argues that people will know which ministry they should enlist in intuitively or through the Holy Spirit, and do so voluntarily without church leaders' intervention. The seminar model points out that many people need more or better self-perception before they are ready to commit to a ministry. Training following this model, with self-assessment tools, can help people improve their self-perception, discover their spiritual gifts, and become consciously committed to the ministry. ${ }^{903}$ Cincala points out that the church needs to show a genuine interest in saving lost people, something that matters to God, and effort must be devoted to helping members become disciples of Christ, actively involved in ministry and mission. ${ }^{904}$

\footnotetext{
901 Edinburgh 2010 Mission Conference, “Theme Three: Mission and Postmodernities," in Edinburgh 2010 II - Witnessing to Christ Today, http://www.edinburgh2010.org/en/study-themes/main-study-themes/mission-andpostmodernitiesccc9.pdf.

902 See Gonçalves, "Witnessing to Christ," 127-30, 132-33.

903 See George G. Hunter II, Church for the Unchurched (Nashville, TN: Abingdon Press, 1996), 127.

${ }^{904}$ Petr Cincala, "Towards Healing the Wounds of Czech Churching: A Sociological Approach with Implications for the S.D.A. Church" (unpublished article, Seventh-day Adventist Theological Seminary, Andrews University, 1999), 47, 49.
} 
Christ's example of recruiting and training the twelve apostles and seventy disciples through prayer and theoretical and practical teaching (Luke 6:12;9:1-6;10:1-20) demonstrates that a balanced seminar model, far from obscuring the intuitive action of the Holy Spirit, complements the work of the divine agent who calls and empowers members to the ministry. In his book The Master Plan of Evangelism, Coleman describes the model Jesus used to recruit and prepare his disciples as made up of eight steps: selection, association, consecration, imputation, demonstration, delegation, supervision, and reproduction. For Coleman, following Christ's example, the priority for church leaders should be training people to reach others with the Gospel. He suggests starting with a few, living with them, forming an action group, and letting them express the things they are learning. In addition, they should be supervised while practicing their ministry, to help them carry their burdens and face problems arising from their ministerial action, as well as supporting them in their personal spiritual experience. ${ }^{905}$

The hesed attitude is also proposed as a principle of mission among the Nones. In practice, the hesed attitude promotes trustworthy relationships, assuming that God manifests an hesed attitude toward human beings, and his representatives must do the same. From this perspective, missionaries must live an experience of faith with God and know his character in order to become instruments of God and reveal his character to the Nones through the same hesed attitude. The aim is to bring people to knowledge of God as the source of hesed, manifested through his representatives. Deep, respectful, disinterested, and intentional relationships are part of hesed action with the Nones. ${ }^{906}$ Canale defines this process as "Being-inmission," through which the Christ of Scripture is elevated before people through the disciples' Books.

${ }^{905}$ Robert E. Coleman, The Master Plan of Evangelism (Grand Rapids, MI: Baker, 1993), 28-145, Apple

${ }^{906}$ See Tompkins, “God`s Mission to the 'Nations,"” 51. 
experience of life. For him, missionaries share the experience of "Being-in-hope," revealing the biblical principles that attest to God's character by living with those around them. ${ }^{907}$

Finally, it is proposed that work with the Nones involve the communal principle (koinonia), following the NT pattern. It is good to remember that the Nones value practical benefits more than the Christian message's cognitive logic. Furthermore, this follows the example of Christ, who did not write a book but dedicated himself to forming a community, ${ }^{908}$ and Christianity itself, which, far from being merely an intellectual and internal faith, is an experience lived in community. ${ }^{909}$ In this sense, the formation of small family groups emphasizing mutual support and relational study of the Bible can be an attraction for the Nones. ${ }^{910}$

\section{The Social Role of Religion}

The Nones tend to recognize religion's social role and sympathize with religious institutions that play an important social role. And, reflecting the postmodern trend of intense interest in "purpose-driven life," they want their lives to have a sense of mission and purpose. ${ }^{911}$ Therefore, it is recommended that mission to them be based on the principle of solidarity action. Most religiously unaffiliated Americans think that churches and other religious institutions benefit society by strengthening community ties and helping the poor. ${ }^{912}$ Oosterwal emphasizes

\footnotetext{
${ }^{907}$ Fernando Canale, "The Message and the Mission of the Remnant: A Methodological Approach," in Message, Mission, and Unity of the Church, ed. Ángel Manuel Rodriguez (Silver Springs, MD: Biblical Research Institute, 2013), 286.

${ }^{908}$ Lesslie Newbigin, The Gospel in a Pluralist Society (Grand Rapids, MI: Eerdmans, 1989), 227.

${ }^{909}$ Philip Yancey, Church: Why Bother? My Personal Pilgrimage (Grand Rapids, MI: Zondervan, 1998).

${ }^{910}$ See Paulien, "The Post-Modern Acts of God," 5.

${ }^{911}$ See Paulien, "The Post-Modern Acts of God," 4.

912 Pew Research Center, "Nones on the Rise."
} 
the value of "caring churches," showing that, far from mitigating only the community's physical needs, this type of church takes a holistic view of human needs. For him, the primary needs of secular people that the church must meet include companionship, community, meaning in life, certainty and security, values, personal dignity, healthy life, social justice, acceptance, and freedom. ${ }^{913}$

Furthermore, J. E. White says that the Nones sympathize with actions that benefit society and the rights of minorities and tend to get involved in projects of this nature, even if promoted by religious institutions. He observes that they are willing to get involved in "a cause" that gives them a sense of purpose in life and has a worthwhile social impact. ${ }^{914}$ White points out that the evangelistic methodology for reaching the secularized mind has in the last decades followed the following pattern: 915

- 1950s-1980s - Unchurched - Christ - Community - Cause

- 1990s-2000s - Unchurched - Community - Christ - Cause

- 2010s- Nones - Cause - Community - Christ

The social aspect of the Gospel follows the very example of Christ. He defended ministry to the needy as the symbol of faith that saves on judgment day (Matt 25:31-41). Furthermore, above all, he won people's trust by getting involved with them and meeting their needs. ${ }^{916}$ Social ministry among the Nones can be a useful missiological principle, as it will capture their trust

${ }^{913}$ Oosterwal, "The Process of Secularization," 59.

${ }^{914}$ White, Rise of the Nones, 99-109.

${ }^{915}$ White, Rise of the Nones, 101.

${ }^{916}$ See Ellen G. White, The Ministry of Health and Healing (Silver Spring, MD: Ellen G. White Estate, 2017), 92. 
and involvement, opening the opportunity for a practical approach for the formation of a relational community and biblical instruction.

The incarnational principle is also proposed as a way of approaching the Nones. The church's real presence in the community, through its members, in an attitude of service, fulfilling what the missiologists call incarnational ministry, arouses the sympathy of the Nones and creates a bridge of rapprochement. The church's attitude in becoming part of the community and communicating the Gospel in a language that the Nones understand earns their trust and respect. First, because it highlights the social role of religion, something attractive to them; second, because the Nones are attracted by example much more than by theoretical teaching, and they admire selflessness and the testimony of practical life experience. The Christian faith is confirmed when it is observed in selfless service. Finally, the Nones are attracted to an incarnational ministry because they seek to feel useful and necessary by contributing to a humanitarian cause and achieving a sense of purpose in life. ${ }^{917}$

\section{Cross-Cultural Barriers}

Working with the Nones is a cross-cultural mission, due to the difference between the group's worldview and the biblical-Christian worldview. Thus, it is proposed that the mission effort with this group obey the principle of contextualization. Defending the fact that the entire biblical text, including OT and NT, is missional in nature- - both in God's purpose and in the multiple contexts where it was formed - Christopher Wright points out that contextualization is already an intrinsic quality of the biblical text, not something added to give the real text meaning.

\footnotetext{
917 See Gonçalves, "Witnessing to Christ,” 133-34.
} 
In other words, contextualization is a missional project based on Scripture itself and has been part of the mission of the people of God throughout their existence. ${ }^{918}$

As seen in Paul's speech at the Areopagus in Athens, the exposure of the Gospel in a cross-cultural context needs to be linked to principles that facilitate communication. The aim is to preserve the biblical content while making it attractive and understandable to listeners. In this sense, the themes must be adapted to the needs of the audience.

In the Nones' case, essential principles of contextualized communication include using illustrations familiar to them, narrative exposition in which the themes appear throughout stories instead of being presented systematically and cognitively, a conciliatory tone, and the presentation of themes as a relationship and as functional realities. J. E. White points out that the visual environment, language, and music are also critical elements in contextualizing the Gospel for the Nones. ${ }^{919}$ It was effective for Paul's audience, and contextualization of communication is especially appropriate for the Nones in the US and Brazil most affected by the disenchantment predicted in Weber's theory of secularization, especially those who declare themselves to be atheists or agnostics. As White recalls, it is necessary to adapt the evangelistic work to the condition of the audience..$^{920}$

\section{Cultural and Religious Plurality}

Most Nones in the cultures under study confirm Durkheim's theory of the permanent and at the same time changing nature of religion - they maintain religious belief but are constantly

\footnotetext{
${ }^{918}$ Christopher J. H. Wright, "Reading the Old Testament Missionally," in Reading the Bible Missionally, ed. Michael W. Goheen (Grand Rapids, MI: Eerdmans, 2016), 109-10.

${ }^{919}$ White, Rise of the Nones, 155-56.

${ }^{920}$ Ellen G. White, Evangelism (Silver Spring, MD: Ellen G. White Estate, 2014), 57.
} 
searching for new forms of spiritual experiences. ${ }^{921}$ Considering this and the pluralism of the Brazilian and American societies in which the Nones live, it is proposed to use the principle of diversity of approaches in order to reach the various distinct groups that make up the Nones and address their search for a diversified religious experience. The cultural and religious diversity and pluralism of the Nones require that mission to them also be multidimensional and pluriform. ${ }^{922}$

Wuthnow, a researcher at Princeton University, points out, for example, the deficiency of American society in meeting the needs of young adults between the ages of twenty and thirty in the country. He notes that while children, teenagers, and young people up to college have a network of support institutions involving daycare centers, elementary and high schools, colleges, universities, the army, and churches, after they finish college, young adults face an institutional support gap. According to Wuthnow, decisions such as how to raise children, where to live, and how to manage one's career are being made based on improvisation, with high levels of debt, divorce, child abuse, and individualism among people in this age group. ${ }^{923}$ Wuthnow argues that congregations can be a valuable support for young adults if they use an appropriate approach. This group is characterized by looking at life practically and not accepting just one way of doing things. They improvise, use ideas and skills to innovate, and make contact with whoever can give them information they need. For them, problems are not solved using pre-defined solutions. ${ }^{924}$

\footnotetext{
${ }^{921}$ Durkheim, Elementary Forms, 429, 432.

922 Oosterwal, "The Process of Secularization," 59.

${ }^{923}$ Wuthnow, After the Baby Boomers, 12, 13, 17.

${ }^{924}$ Wuthnow, After the Baby Boomers, 13.
} 
Bringing in the spiritual aspect, Wuthnow says that young adults take a "tinkering" approach, meaning that they create their religious life from the skills, ideas, and resources previously available to them. They have a perspective that involves practical religiosity without standardized and institutionalized formulas. He writes that young adults' spirituality can be classified as "bricolage," which implies the union of apparently inconsistent and disparate components, forming a diverse mosaic according to the individual's taste. It is a relativistic approach in which each individual is a tinkerer, claiming their truth in salvation, morality, and civility. Wuthnow also describes them as "spiritual seekers," or people looking for answers in a context of uncertainty. Thus, religious institutions' challenge is to understand young adults in practical terms, based on the changing social factors involving this group, such as marriage, child-rearing, professional career management, and style of spiritual practice. ${ }^{925}$ As noted in the previous chapters, most Nones are young, ${ }^{926}$ and Wuthnow's research points to the need for a series of approaches that meet the group's demands based on these social factors.

In general, among the diverse approaches identified as significant for working with the Nones are the education of children, social causes, communities, healthy lifestyle, an integrational approach, small relational groups, support groups, lay ministries or social network evangelism, contextualized language and music, professional career management, and practical spirituality. ${ }^{927}$

\footnotetext{
${ }^{925}$ Wuthnow, After the Baby Boomers, 13-15. the Nones.

${ }^{926}$ See Pew Research Center, “A Closer Look”; Pew Research Center, "Nones on the Rise”; White, Rise of

${ }^{927}$ See White, Rise of the Nones, 155-56; Hunter, Church for the Unchurched, 32, 103, 157; Wuthnow, After the Baby Boomers, 13-15.
} 


\section{Mass Communication/Technology ${ }^{928}$}

The Nones in both cultures take a critical view of religious mass communication. On the one hand, they believe churches use it to compete for members, spread quackery, seek political power, and accumulate wealth for religious leaders. On the other hand, many of them benefit from religious products widely accessible through the media. ${ }^{929}$ Therefore, the principle of judicious use of mass media is proposed. This means not using media for political-electoral purposes and other activities that involve personal gain for religious leaders. An additional proposed principle is balanced use of media for commercial matters, such as the sale of products or fundraising campaigns. According to Pew Research Center, the concept of separation between church and state leads the Nones to repudiate religious involvement in political parties or roles they consider to be legitimate for the state. ${ }^{930}$ In Brazil, most young people oppose the idea of a

\footnotetext{
928 This dissertation analyzed the Nones' perspective on religious dissemination through the mass media, mainly TV, radio, and the internet. The researcher noted a lack of work involving social media's impact on the Nones in Brazil and the United States. The absence of research relating these two vectors-Nones and social media - is a significant gap, considering that the most representative age group of the Nones is the one that consumes the most social media-young adults. At the other extreme, the smallest age representation of Nones occurs among people aged 65 and over, who have the lowest social media consumption. A Pew Research Center survey found that 50 percent of Americans aged 18 to 29 got news online, versus 27 percent on TV, 14 percent on radio, and 5 percent through print news. On the other hand, among Americans aged 65 and over, only 20 percent got news online, compared to 85 percent on TV, 24 percent on radio, and 48 percent through print. Some of the central values espoused by the Nones - relationships and humanitarian/social causes - are among the main reasons people use social media. According to the New York Times Consumer Insight Group, 84 percent of people share information on social media to support causes or issues of great value to them, and 78 percent to nurture relationships. The impact of social media on vital aspects of society such as politics, business, culture, education, professional careers, and innovation seems to indicate that the Nones in Brazilian and American cultures suffer some impact from this emerging phenomenon. See Pew Research Center, "The Modern News Consumer: News Attitudes and Practices in the Digital Era," July 7, 2016, https://www.journalism.org/2016/07/07/the-modern-news-consumer/; Text ex Machina, "New York Times Study: The Psychology of Sharing: Why Do People Share Online?," July 18, 2011, http://text-ex-machina.co.uk/blog/new-york-times-study.html; Simplilearn, "Understanding the Impacts of Social Media: Pros and Cons," September 22, 2020, https://www.simplilearn.com/real-impact-social-media-article.

${ }^{929}$ See Santana, "Religião e mercado," 67; Weber, The Protestant Ethic, 105-12. Discomfort."

${ }^{930}$ Pew Research Center, “Why America’s 'Nones’ Left Religion”; Pew Research Center, “Little Voter
} 
religious leader running for political office, as well as politicians making speeches in religious spaces. ${ }^{931}$

A third proposed principle is adequacy in the use of mass media to discuss biblical themes. This means addressing topics directly appealing to the Nones, as already seen in a previous section of this chapter. White stresses that the means of mass communication must be seen as an opportunity and must be used to carry the Gospel with a broad reach, since biblical instruction, in this context, will produce roots and precious spiritual fruits. ${ }^{932}$ The Nones value freedom of choice, eclectic spirit, and access to the mass media's religious products. ${ }^{933}$

Considering that the Nones are also sympathetic to initiatives by religious entities that promote social well-being and care for the environment, ${ }^{934}$ it is proposed that the mass media be used by religious institutions to promote and discuss humanitarian causes, social justice, physical-emotional well-being, service to others, family care, and environmental causes. ${ }^{935}$

\section{Summary}

The cultural and missional implications discussed here for working with the Nones in Brazil and America reflect the information in previous chapters. The study proposed eight areas considered sensitive for the missional relationship with the nones in both cultures. Some of these can be considered critical, and others as an opportunity for mission. The areas are the identity of

\footnotetext{
931 Fundação Perseu Abramo, “Percepções e valores políticos nas periferias de São Paulo,” Pesquisas de percepção social e opinião pública, April 5, 2017, accessed February 10, 2020, https://fpabramo.org.br/publicacoes/publicacao/percepcoes-e-valores-politicos-nas periferias-de-sao-paulo/.

${ }^{932}$ White, Prophets and Kings, 47.

933 Pew Research Center, “More See 'Too Much’ Religious Talk.”

934 Pew Research Center, "Nones on the Rise."

935 See Rodrigues, "Religiosos sem igreja," 51; White, Rise of the Nones, 143-48.
} 
God, the Bible as the source of truth, institutional religion, relationships and community, the social role of religion, cross-cultural barriers, cultural and religious pluralism, and mass communication.

The characteristics of Nones related to each area were presented, and then, missiological and sociological principles were suggested to fill the gaps in the respective areas, forming a bridge of contact with the Nones. Table 13 lists the corresponding areas and principles. 
Table 13. Sensitive Areas and Principles

\begin{tabular}{|c|c|}
\hline Sensitive Areas for the Nones & Suggested Principles \\
\hline 1. God's identity & $\begin{array}{l}\text { An approach that emphasizes God's personal, } \\
\text { loving, and powerful character } \\
\text { - The manifestation of God's saving power } \\
\text { - The expression of God's energy } \\
\text { - Jesus as the perfect revelation of God }\end{array}$ \\
\hline 2. The Bible as the source of truth & 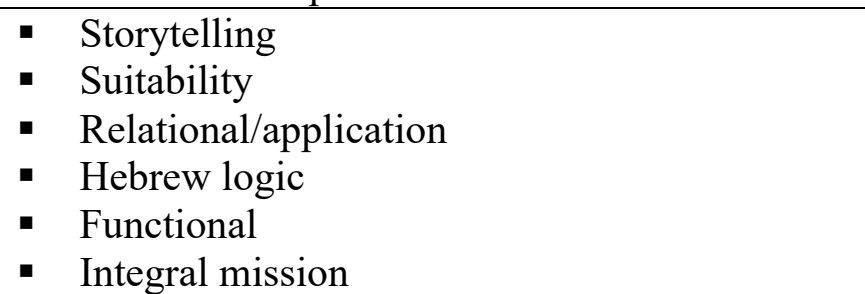 \\
\hline 3. Institutional religion & $\begin{array}{l}\text { - Salt model of evangelism } \\
\text { - } \\
\text { - Apprall relational groups } \\
\text {. }\end{array}$ \\
\hline 4. Relationship and community & $\begin{array}{ll}\text { - } & \text { Friendship evangelism } \\
\text { - } & \text { hesed } \text { attitude } \\
\text { - } & \text { Communal (koinonia) } \\
\end{array}$ \\
\hline 5. Social role of religion & $\begin{array}{ll}\text { - } & \text { Solidarity action } \\
\text { Incarnational ministry }\end{array}$ \\
\hline 6. Cross-cultural barriers & - Contextualization \\
\hline 7. Cultural/religious pluralism & - Diversity of approaches \\
\hline 8. Mass communication/technology & $\begin{array}{ll} & \text { Judicious/non-political use } \\
\text { - } & \text { Balance in commercial matters } \\
\text { - } & \text { Humanitarian and socio-environmental causes } \\
\end{array}$ \\
\hline
\end{tabular}




\section{CHAPTER VI}

\section{SUMMARY, CONCLUSION, AND RECOMMENDATIONS}

\section{Summary}

This dissertation aimed to study the Nones in Brazil and the United States in the light of secularization theories, from the perspective of the sociology of religion, providing a conceptual basis that would offer insights and missiological principles for working with the Nones. In the first chapter, a brief research background was provided, the problem and purpose were established, and the methodology and conceptual framework were explained. The research's main terms were defined the first time they appeared in the text, making an exclusive section for this purpose unnecessary.

The second chapter explored twelve characteristics of secularization as theorized by the parents of the sociology of religion, Max Weber and Emile Durkheim, and seven of their followers, as well as three independent scholars from the same branch of sociology: Peter Berger, Charles Taylor, and Talal Asad. It was clear that these elements, evoked based on the Enlightenment's assumptions of the modern period, achieved their most significant consolidation with postmodernism, weakening some aspects of religion and strengthening others.

The third chapter provided an analysis of the Nones in the two cultures under study, in light of the elements of secularization discussed in the previous chapter, classified into six categories. These elements are reflected in the experience of the different groups that make up 
the Nones, leading to the conclusion that the Nones are a product of the modern and postmodern influences of contemporary secularization.

The fourth chapter explored a biblical framework for mission work with the Nones based on two OT and two NT narratives. These narratives demonstrate evidence of Missio Dei in favor of foreigners, allowing the extraction of missiological principles that shed light on the crosscultural mission among the different groups of contemporary Nones in Brazilian and American societies.

Based on the study in the previous chapters, the fifth chapter identified and analyzed some of the most critical implications for mission among the Nones of the cultures under study. The survey proposed eight sensitive areas, some critical and others presenting opportunities to work with the group. The characteristics of each area were considered, and then missiological and sociological principles were suggested to fill the gaps in that area and carry out the mission with the Nones.

\section{Conclusion}

The secularization process in contemporary societies has been both latent and deliberate. The latent aspect can be observed as the various subsystems of society, such as the economy, education, and medicine, become more specialized and professional, gradually decreasing the influence of religion. Simultaneously, in the modern era, deliberate policies have been created to reduce the influence of religion in specific areas such as government and education. However, predictions about the disappearance of religion have not been fulfilled, and no entirely secular society has been found. Not only has religion persisted, but in many cases, it has grown and taken on a leading role in contemporary societies, masked by dynamic globalization. 
Analysis of secularization theories, based on the Enlightenment assumptions of modernism and enhanced by the assumptions of postmodernism, allows us to conclude that the Nones are a product of the modern and postmodern influences of contemporary secularization. In this sense, it can be said that the main causes for the phenomenon of the Nones are associated with the development of human thought from the Enlightenment movement to the present day. Among the main legacies of modern enlightenment reflected today in the Nones is the principle of separation between church and state and the autonomy of the individual, described by Taylor as "ethics of authenticity," according to which all human beings are ontologically autonomous. Therefore, each person must realize humanity in a specific and personal way. ${ }^{936}$

Among the main causes of the Nones' phenomenon associated with postmodernism are relativism and the functional aspect of religion — the religious menu is built individually, following the criterion of personal taste and functionality. ${ }^{937}$ Other causal influences for the Nones' phenomenon are the emphasis on direct communication with the transcendent, without institutional mediation, and metaphysical, subjective, and existentialist religiosity—without a dogmatic parameter, brought to the fore by modern spiritualism originated in the late 19th century. ${ }^{938}$ Finally, scientific and technological advancement is also a causal factor for the phenomenon of the Nones, insofar as it promotes secularism, reflected especially in the Nones classified as atheists and agnostics, and also for facilitating pluralism, weakening institutional

\footnotetext{
936 Taylor, The Ethics of Authenticity, 50.

937 Erickson, Truth or Consequences, 111-82.

${ }^{938}$ See Fuller, Spiritual, But Not Religious, 38-44; Hill, Spiritualism, Its History, 30-43; Carroll, Spiritualism in Antebellum America 3, 16-34; Braude, Radical Spirits: Spiritualism 10-12, 169-72.
} 
boundaries, and promoting religious switching, culminating in the Nones, as the last step in the process.

As youth are the most susceptible to social change, the Nones are most substantially represented among young people in the two societies studied. Despite being the group in Brazil and the United States most affected by religious disenchantment, as predicted by Weber and his disciples through the secularization aspect of legislation or conscience, most Nones continue to believe in God and practice some personal and subjective spirituality.

It is also concluded that the SBNRs are the most accessible group of Nones because, despite their aversion to institutional religion, they are open to spiritual discussion and seek a spiritual experience that satisfies them, like the God-fearers in the NT. Their tendency toward subjective and fluid spirituality and their rejection of dogmatic religion are rooted in modern spiritualism that emerged in the late nineteenth century.

It is concluded that, although Brazilian Nones are generally less secularized than American Nones, several characteristics unite them in both cultures: they defend separation between church and state and the privatization of religion, value the social role of religion and religious pluralism, reject institutional religion, and relativize the content of faith.

As attested by Berger, religious pluralism generates an increase in religious disaffiliation and contributes to the growth of the Nones, especially those who declare themselves to be atheists, agnostics, indifferent, and SBNRs. Likewise, the permanent and changing nature of religion, perceived by Durkheim, has contributed to the increasing number of Nones in both cultures. Social transformations and pluralism have generated a religious movement toward the Nones. In America, the movement tends to go from traditional Christianity—Catholicism, mainline Protestantism, historical black Protestant churches - to evangelical Protestantism, and 
from there to the Nones. In Brazil, people tend to move from traditional denominations, to Pentecostalism, to Neopentecostalism, then to independent evangelical churches, and, finally, to the Nones. In other words, in both countries, most of the population has retained religiosity, but has changed their way of expressing it.

The "contemporary secular" described by Asad, which echoes Davis and Luckmann's writings, is possibly the most appropriate image to describe the majority of the Nones in the two cultures under study. This figure assimilates modern and postmodern society's principlesfreedom, individuality, relativism, syncretism, and acceptance of differences, among otherswhile maintaining spiritual values on a subjective basis.

It is concluded that the study of biblical narratives that attest to Missio Dei among foreigners, in both the OT and NT, can contribute principles and insights for cross-cultural mission among contemporary Nones. The narratives of the conversion of Naaman and Ruth, the conversion of Cornelius and his family and friends, and Paul's speech at the Areopagus in Athens provided the following principles for cross-cultural mission: mission based on the manifestation of God's saving power, mission based on the principle of hesed action, mission based on biblical instruction, and mission based on contextualization.

Although the Nones reject religious institutions as mediators of their relationship with the transcendent, it is concluded, based on this study, that the local congregation still plays an important role in the spiritual development of members and the formation of communities. In addition, the congregation plays a significant role in the development and discipleship of church members to fulfill the Christian mission. However, the Nones must be reached through a personal approach, incorporating friendship evangelism, the salt model of evangelism, the hesed 
attitude, and small relational groups. At the right time, the Nones will overcome their prejudice against institutions and eventually join the church's collective worship.

Finally, it is concluded that there are at least eight areas considered sensitive in the missional relationship with the Nones in both cultures under study. Some of these areas are critical or difficult to relate to from a missional perspective. The first area is the identity of God. Most of the Nones reject religion, but not God. However, few of these believe in the God described by the Bible; most see God as a force or energy. Mission work based on God's saving power, the NT's focus on God's energy, and the study of the person of Christ as the perfect revelation of God may help this group of Nones have a real encounter with God.

The second critical area in the relationship with the Nones is the Bible as the source of truth. Affected by postmodern influence, the Nones relativize faith's content, reducing truth to the individual level. Storytelling, adequacy, relational/application study, Hebrew logic, functional focus, and integral mission are the principles suggested for bringing these Nones closer to the biblical text.

The third critical area is institutional religion. The Nones reject religious institutions, seeing them as a symbol of oppression and power. Thus, the salt model of evangelism and relational small groups are suggested as ways to reach them, rather than congregationally based approaches. The fourth critical area is cross-cultural barriers, arising from the difference between the Nones' worldview and the biblical worldview. The principle of contextualization, suggested in this research, can help overcome these barriers.

Three areas present opportunities in the missional relationship with the Nones, or cases where the Gospel can offer what they crave. The first of these is cultural/religious pluralism. The Nones appreciate access to religious products, syncretism, and the freedom provided by 
pluralism, although they criticize the competition for members and the commercial nature of the faith encouraged by the same pluralism. Diversity of approaches is a suggested principle to deal with the Nones in a pluralistic society. This includes multisensory worship experiences so that the Nones are exposed to Jesus and God's saving power.

The second area of opportunity is relationship and community. As seen, Nones value relationships and community experience. This research suggests friendship evangelism, otherness, hesed attitude, and koinonia (community) as practical principles for the missional relationship with the Nones in this area. The goal is to develop communities in which they feel accepted before they make a cognitive decision.

The third area of opportunity is the social role of religion. The Nones welcome institutions that provide social services for the benefit of needy people and the environment. The principles of solidarity action and incarnational ministry can demonstrate the social role of religion and show the Christian community's authenticity to the Nones.

Finally, the area of mass communication/technology represents both a critical relationship and an opportunity with the Nones. They appreciate religious products that are accessible through the media, but they are critical of churches using the media to seek membership, exert political influence, and obtain financial benefit. Therefore, some recommended principles for mass communication in the missional relationship with the Nones are judicious/non-political use of media, balance in matters of a commercial nature, ensuring content is relevant to the interest of the listener, and raising awareness of humanitarian and socio-environmental causes.

The missiological insights and principles for approaching the Nones in each of the areas discussed above are based on study of this group in Brazil and the United States. The conceptual 
basis for this study was constructed in the light of secularization theories and the biblical framework presented (see Table 14 below). Application of these insights will facilitate getting closer to people who identify as Nones. This study also points out the responsibility and privilege that Christ's disciples experience, seeing the cultural wave of contemporary change as one of the most significant opportunities to reach the Nones for Christ. 
Table 14. Theoretical Conceptual Diagram

\begin{tabular}{|c|c|}
\hline $\begin{array}{l}\text { Twelve Selected Elements that Characterize the Theories of } \\
\text { Secularization Summarized in Six Categories } \\
\text { (Chapters II and III) }\end{array}$ & $\begin{array}{l}\text { Four Biblical Principles for } \\
\text { Missio Dei among Foreigners } \\
\text { (Chapter IV) }\end{array}$ \\
\hline $\begin{array}{l}\text { 1. Religious disenchantment } \\
\text { 2. Weakening of the public influence of religion and, as a } \\
\text { consequence, the transference of religion from the public sphere } \\
\text { to the private sphere, and a negative attitude toward religious } \\
\text { institutions } \\
\text { 3. Religious pluralism in a market environment and the } \\
\text { multiplication of religious groups, relativism of the content of } \\
\text { faith, religious syncretism, and an attitude of believing without } \\
\text { belonging } \\
\text { 4. The changing and permanent nature of religion } \\
\text { 5. The contemporary secular that upholds both modern and } \\
\text { postmodern values and principles of faith } \\
\text { 6. The influence of technological advances and mass } \\
\text { communication }\end{array}$ & $\begin{array}{l}\text { 1. Mission based on } \\
\text { relationships or the hesed } \\
\text { attitude (Naomi and Ruth } \\
\text { - book of Ruth) } \\
\text { 2. Mission based on the } \\
\text { saving power of God } \\
\text { (Naaman - } 2 \text { Kgs } 5: 1-19 \text { ) } \\
\text { 3. Mission based on biblical } \\
\text { instruction (Cornelius - } \\
\text { Acts 10) } \\
\text { 4ission based on } \\
\text { contextualization (Paul's } \\
\text { speech in Athens - Acts } \\
\text { 17) }\end{array}$ \\
\hline
\end{tabular}

\section{Conceptual Bases}

\begin{tabular}{|c|c|}
\hline $\begin{array}{l}\text { Sensitive Areas for the Nones } \\
\text { (Chapter V) }\end{array}$ & $\begin{array}{l}\text { Suggested Principles for Mission among Nones } \\
\text { (Chapter V) }\end{array}$ \\
\hline 1. God's identity & $\begin{array}{l}\text { - An approach that emphasizes God's personal, loving, } \\
\text { and powerful character } \\
\text { - The manifestation of God's saving power } \\
\text { - The expression of God's energy } \\
\text { - Jesus as the perfect revelation of God }\end{array}$ \\
\hline 2. The Bible as the source of truth & $\begin{array}{ll}\text { - } & \text { Storytelling } \\
\text { - } & \text { Suitability } \\
\text { - } & \text { Helational/application } \\
\text { - } & \text { Functional } \\
& \text { Integral mission } \\
\end{array}$ \\
\hline 3. Institutional religion & $\begin{array}{ll}\text { - } & \text { Salt model of evangelism } \\
\text { - } & \text { Small relational groups } \\
\text { Approaching Christian identity }\end{array}$ \\
\hline 4. Relationship and community & $\begin{array}{ll}- & \text { Friendship evangelism } \\
\text { - } & \text { Otherness } \\
\text { - } & \text { Communal } \text { attitude } \\
\end{array}$ \\
\hline 5. Social role of religion & $\begin{array}{ll}\text { - } & \text { Solidarity action } \\
\text { - } & \text { Incarnational ministry } \\
\end{array}$ \\
\hline 6. $\quad$ Cross-cultural barriers & - Contextualization \\
\hline 7. Cultural/religious pluralism & - $\quad$ Diversity of approaches \\
\hline 8. Mass communication/technology & 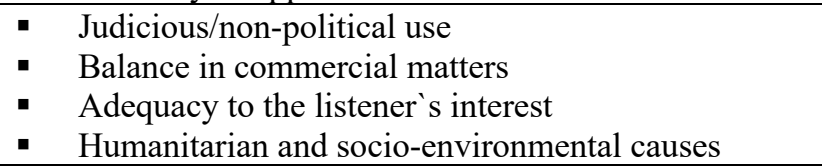 \\
\hline
\end{tabular}




\section{Recommendations}

This dissertation investigated the Nones in the light of secularization theories from the field of sociology of religion. However, the study of the church's mission for this specific group is far from complete. This research has revealed several areas of concern that need to be addressed. Further investigation and evaluation of the practical applications of the suggested principles are recommended. In addition, studies and investigations of the Nones in specific contexts within Brazilian and American cultures are recommended to better understand and address specific cultural characteristics. Field research with Christians who previously identified as Nones may also provide useful information and principles for mission work with current Nones.

Given the absence of research regarding the impact of social media on the Nones, further research on this subject is strongly recommended. As seen in the previous chapter, there is evidence pointing to some affinity between these topics. The biggest consumers of social media, young adults, are also the most representative group of the Nones. In addition, Nones and consumers of social media share an interest in relationships and causes of social and humanitarian value.

An intentional and planned action by the church is recommended to promote the mission among Nones. Such a project may involve theological education, mission agencies, and training in practical approaches, among other elements. The growth in the number of Nones in recent decades requires a proportionate effort on the part of the church to reach them for Christ. 


\section{BIBLIOGRAPHY}

Agência Nacional do Cinema. "ANCINE divulga informe sobre programação na TV aberta do ano de 2015." June 17, 2016. https://www.ancine.gov.br/pt-br/salaimprensa/noticias/ancine-divulga-informe-sobre-programa-o-da-tv-aberta.

Almeida, Ronaldo A., and Paula Monteiro. “Trânsito religioso no Brasil.” Scielo Analytics, São Paulo Perspectiva 15, no. 3 (2001): 92-101. http://www.scielo.br/scielo.php?script=sci_arttext\&pid=S0102-88392001000300012.

Almeida, Ronaldo A., and R. Barbosa. "Transição religiosa no Brasil." In Trajetórias das desigualdades: Como o Brasil mudou nos últimos cinquenta anos, edited by Marta Arretche, 335-65. São Paulo: Editora Unesp, 2015.

Alves, José Eustáquio Diniz. “A transição religiosa na América Latina e no Brasil.” EcoDebate. May 31, 2017. https://www.ecodebate.com.br/2017/05/31/transicao-religiosa-na-americalatina-e-no-brasil-artigo-de-jose-eustaquio-diniz-alves/.

. "Transição religiosa-Católicos abaixo de 50\% até 2022 e abaixo do percentual de evangélicos até 2032.” EcoDebate. December 5, 2018.

https://www.ecodebate.com.br/2018/12/05/transicao-religiosa-catolicos-abaixo-de-50ate-2022-e-abaixo-do-percentual-de-evangelicos-ate-2032-artigo-de-jose-eustaquio-dinizalves/.

. “Uma projeção linear da transição religiosa no Brasil: 1991-2040.” EcoDebate. January 11, 2017. https://www.ecodebate.com.br/2017/01/11/uma-projecao-linear-da-transicaoreligiosa-no-brasil-1991-2040-artigo-de-jose-eustaquio-diniz-alves/.

Alves, José Eustáquio Diniz, and Maria Salet F. Novellino. "A dinâmica das filiações religiosas no Rio de Janeiro (1991-2000): Um recorte por educação, cor, geração e gênero.” In $A$ ence aos 50 anos, um olhar sobre o Rio de Janeiro, edited by N. Patarra et al. Vol. 1, 275-308. Rio de Janeiro: ENCE/IBGE, 2006.

Alves, José Eustáquio Diniz, Luiz Felipe Walter Barros, and Suzana Cavenaghi. “A dinâmica das filiações religiosas no Brasil entre 2000 e 2010: diversificação e processo de mudança de hegemonia." REVER 12, no. 2 (July/December 2012): 145-74.

Alves, José Eustáquio Diniz, Suzana Marta Cavenaghi, Luiz Felipe Walter Barros, and Angelita A. de Carvalho. "Distribuição espacial da transição religiosa no Brasil." Tempo Social 29, no. 2 (August 2017): 215-42.

Amado, Jorge. Jubiabá. 40th ed. Rio de Janeiro: Record, 1981.

Antoniazzi, Alberto. “As religiões no Brasil segundo o censo de 2000.” REVER 2 (2003): 75-80. 
Antunes, Anderson. "The Richest Pastors in Brazil.” Forbes.com. January 17, 2013. https://www.forbes.com/sites/andersonantunes/2013/01/17/the-richest-pastors-inbrazil/\#22c335ab5b1e.

Aratus. "Phaenomena." Theoi Classical Texts Library. https://www.theoi.com/Text/AratusPhaenomena.html.

Aristotle. The Art of Rhetoric. Translated by J. H. Freese. Loeb Classical Library 193. Cambridge, MA: Harvard University Press, 2020.

Armstrong, Ben. The Electric Church. Nashville, TN: Thomas Nelson, 1979.

Asad, Talal. Formations of the Secular: Christianity, Islam, Modernity. Stanford, CA: Stanford University Press, 2003.

—. "Religion, Nation-State, Secularism." In Nation and Religion: Perspectives on Europe and Asia, edited by Peter van der Veer and Hartmut Lehmann. Princeton, NJ: Princeton University Press, 1999.

_. "Responses." In Powers of Secular Modern: Talal Asad and His Interlocutors, edited by David Scott and Charles Hirschkind. Stanford, CA: Stanford University Press, 2006.

- "Secularism, Hegemony, and Fullness." The Immanent Frame: Secularism, Religion, and the Public Sphere (blog), November 17, 2007, http://blogs.ssrc.org/tif/2007/11/17/secularism-hegemony-and-fullness/.

Assman, Hugo. A igreja eletrônica e seu impacto na América Latina: convite a um estudo. Petrópolis: Vozes, 1986.

Auld, A. Graeme. I \& II Kings. Daily Study Bible Series. Philadelphia: Westminster Press, 1986.

Azzi, Corry, and Ronald G. Ehrenberg. "Household Allocation of Time and Church Attendance." Journal of Political Economy 83, no. 1 (1975): 27-56.

Baker, Joseph O., and Buster G. Smith. American Secular: Cultural Contours of Nonreligious Belief Systems. New York: New York University Press, 2015.

Barna, George. Revolution. Wheaton, IL: Tyndale House, 2005.

Barrett, C. K. Acts 1-14. International Critical Commentary. Edinburgh: T\&T Clark, 1994.

Barrett, David B., and Todd M. Johnson. World Christian Trends AD 30-AD 2200: Interpreting the Annual Christian Megacensus. Pasadena, CA: William Carey Library, 2003.

Bartz, Alessandro. "Trânsito religioso no Brasil: Mudanças e tendências contemporâneas." Congresso Internacional da Faculdades Est 1 (2012): 258-73. http://anais.est.edu.br/index.php/congresso/article/view/27.

Bassler, J. M. "Luke and Paul on Impartiality.” Biblica 66 (1985): 546-52. 
Bauman, Zygmunt. Modernidade líquida. Rio de Janeiro: Jorge Zahar, 2001.

Baylor University. "Wave III of the Baylor Religion Survey Examines How Religion Affects Individuals ' Outlook and Well-Being in Tumultuous Times." September 20, 2011. https://www.baylor.edu/mediacommunications/news.php?action=story\&story=100503.

Berger, Peter L. “A Bleak Outlook Is Seen for Religion.” New York Times, April 25, 1968.

__ "Epistemological Modesty: An Interview with Peter Berger." Christian Century 114 (1997): 972-78.

- The Many Altars of Modernity: Toward a Paradigm for Religion in a Pluralist Age. Boston, MA: Walter de Gruyter, 2014.

- Questions of Faith: A Skeptical Affirmation of Christianity. Malden, MA: Blackwell, 2004.

- The Sacred Canopy: Elements of a Sociological Theory of Religion. Garden City, NY: Anchor/Doubleday, 1966.

—. Una gloria remota. Avere fede nell' epoca del pluralismo. Bologna: Il Mulino, 1994.

Berger, Peter L., and Anton C. Zijderveld. In Praise of Doubt: How to Have Convictions Without Becoming a Fanatic. New York: Harper Collins, 2009.

Berger, Peter L., and Thomas Luckmann. Modernity, Pluralism and the Crisis of Meaning: The Orientation of Modern Man. Gütersloh: Bertelsmann Foundation, 1995.

- The Social Construction of Reality: A Treatise in the Sociology of Knowledge. London: Penguin Books, 1966.

Bevans, Stephen B. Models of Contextual Theology. New York: Orbis Books, 2002.

Block, Daniel I. Judges, Ruth. New American Bible Commentary. Nashville: Broadman \& Holman, 1999.

Bock, Darrell L. Acts. Baker Exegetical Commentary on the New Testament. Grand Rapids, MI: Baker Academic, 2007. iBooks.

Blomberg, Craig. Matthew. New American Commentary 22. Nashville: Broadman \& Holman Publishers, 1992.

Bonhoeffer, Dietrich. Prisoner for God: Letters and Papers from Prison. New York: Macmillan, 1953.

Boris, Fausto. História do Brasil. São Paulo: Edusp, 1995.

Bosch, David J. Transforming Mission: Paradigm Shifts in Theology of Mission. Maryknoll, NY: Orbis Books, 2004. 
Brandão, Carlos Rodrigues. "Ser Católico: Dimensões Brasileiras-um estudo sobre a atribuição da identidade através da religião." In Brasil e EUA: religião e identidade nacional, edited by Roberto Damatta and Rubem Cesar Fernandes, 27-58. Rio de Janeiro: Graal, 1988.

Braude, Ann. Radical Spirits: Spiritualism and Women's Rights in Nineteenth-Century America. Boston: Beacon Press, 1989.

Braude, W. G. Jewish Proselyting in the First Five Centuries of the Common Era: The Age of the Tannaim and Amoraim. Providence: Brown University Press, 1940.

"Brazilian Churches as Media Owners." Media Ownership Monitor Brasil, Repórteres sem Fronteiras e Intervozes. Accessed April 5, 2020. https://brazil.mom-rsf.org.

Brodie, Thomas L. The Gospel According to John: A Literary and Theological Commentary. New York: Oxford University Press, 1993.

Bruce, F. F. The Book of the Acts. New International Commentary on the New Testament. Grand Rapids, MI: Eerdmans, 1998.

Bull, Robert J. “A Mithraic Medallion from Caesarea.” Israel Exploration Journal 24, no. 3, 4 (1974): 187-90.

Calvin, John. “1 John 1.” Bible Hub. https://biblehub.com/commentaries/calvin/1_john/1.htm.

Camargos, Malco, ed. Transcrição da gravação dos grupos dos sem religião. Belo Horizonte: Vertex Pesquisa, 2012.

Campbell, E. F. Jr. Ruth. Garden City: Doubleday, 1975.

Campos, Leonildo Silveira. "Evangélicos, Pentecostais e carismáticos na mídia radiofônica e televisiva." Revista USP, no. 61 (March/May 2004): 146-63.

Camurça, Marcelo. "O Brasil religioso que emerge do censo 2010: Consolidações, tendências e perplexidades.” In Religiões em movimento: O censo de 2010, edited by Faustino Teixeira and Renata Menezes, 63-87. Petrópolis: Vozes, 2012.

—. "O futuro das religiões no Brasil: O enfoque das ciências da religião." In Anais do IV Congresso da ANPTECRE: Associação Nacional de Pós-graduação e Pesquisa em Teologia e Ciências da Religião, edited by Gilbraz Aragão and Newton Cabral, 71-80. São Paulo: ANPTECRE, 2013.

Canale, Fernando. "The Message and the Mission of the Remnant: A Methodological Approach.” In Message, Mission, and Unity of the Church, edited by Ángel Manuel Rodriguez, 261-86. Silver Springs, MD: Biblical Research Institute, 2013.

Cardoso, Rodrigo. "O novo retrato da fé no Brasil—pesquisas indicam o aumento da migração religiosa entre os brasileiros, o surgimento dos evangélicos não praticantes e o crescimento dos adeptos ao Islã." ISTOÉ, August 24, 2011. 
Carpenter, Holly M. Blackwelder. "A Comprehensive Narrative Analysis of the Book of Ruth." Master's thesis, Andrews University, 2005.

Carroll, Bret. Spiritualism in Antebellum America. Bloomington, IN: Indiana University Press, 1977.

Carson, Donald A. The Gagging of God: Christianity Confronts Pluralism. Grand Rapids, MI: Zondervan, 1996.

Carvalho, Leonardo D. “Jorge Amado e o candomblé em jubiiabá: O sincretismo como estratégia para a manutenção da religiosidade Afro-Brasileira na Bahia (1930-1935).” CPGL II Colóquio da Pós-graduação em Letras. Accessed March 17, 2018. http://www.assis.unesp.br/Home/PosGraduacao/Letras/ColoquioLetras/leonardodallacqu a.pdf.

Chapell, Bryan. Christ-Centered Preaching: Redeeming the Expository Sermon. Grand Rapids, MI: Baker Academic, 2018.

Chase, Frederic Henry. The Credibility of the Book of the Acts of the Apostles. Eugene, OR: Wipf and Stock, 2005.

Chaves, Jolivê R. "Evangelismo integrado na divisão Sul Americana da igreja Adventista do Sétimo Dia: Uma descrição.” Doctoral thesis, UNASP, 2014.

Cincala, Petr. "Towards Healing the Wounds of Czech Churching: A Sociological Approach with Implications for the S.D.A. Church.” Unpublished article, Seventh-day Adventist Theological Seminary, Andrews University, 1999.

Clement of Alexandria. "The Stromata, or Miscellanies: Book 1.” Early Christian Writings. http://www.earlychristianwritings.com/text/clement-stromata-book1.html.

Cogan, Mordechai, and Hayim Tadmor. II Kings. Anchor Bible 11. New York: Doubleday, 1988.

Cohen, S. J. D. The Beginnings of Jewishness: Boundaries, Varieties, Uncertainties. Berkeley: University of California Press, 1999.

Coleman, Robert E. The Master Plan of Evangelism. Grand Rapids, MI: Baker, 1993. Apple Books.

Comte, Augusto. Discurso preliminar sobre o Espirito Positivo. São Paulo, SP: Ridendo Castigate Mores, 2002.

"Constitution of the Empire of Brazil." Accessed June 18, 2020. https://en.wikisource.org/wiki/Constitution_of_the_Empire_of_Brazil.

Corbi, Marià. Hacia una espiritualidad laica, sin creencias, sin religions, sin dioses. Barcelona: Editora Herder, 2007. 
Cornthwaite, Christopher J. "Wayward Jews, God-Fearing Gentiles, or Curious Pagans? Jewish Normativity and the Sambathions." Journal for the Study of Judaism 48 (2017): 277-97.

Corrigan, John, and Winthrop S. Hudson. Religion in America. 9th ed. New York: Routledge, 2018.

Corwin, Gary. "Revising Assumption About Resistant." In Reaching the Resistant: Barriers and Bridges for Mission, edited by Dudley Woodberry, 11-21. Pasadena, CA: William Carey Library, 1998.

Cox, Daniel. "Religious Diversity May Be Making America Less Religious." FiveThirtyEight (blog), August 23, 2016. https://fivethirtyeight.com/features/religious-diversity-may-bemaking-america-less-religious/.

Cox, Daniel, E. J. Dionne Jr., Juhem Navarro-Rivera, Robert P. Jones, and William A. Galston. “2012 Pre-Election American Values Survey.” PRRI. October 22, 2012. https:/www.prri.org/research/american-values-survey-2012/.

Cox, Daniel, Juhem Navarro-Rivera, and Robert P. Jones. "Race, Religion, and Political Affiliation of Americans' Core Social Networks.” PRRI. August 3, 2016. https://www.prri.org/research/poll-race-religion-politics-americans-social-networks/.

Cox, Harvey. The Secular City: Secularization and Urbanization in Theological Perspective. Princeton and Oxford: Princeton University Press, 2013.

Cox, Harvey, and Daisaku Ikeda. The Persistence of Religion: Comparative Perspectives on Modern Spirituality. London - New York: I. B. Taurus, 2009.

Crenshaw, James L. Story and Faith: A Guide to the Old Testament. New York: Macmillan, 1986.

Croy, N. C. "Hellenistic Philosophies and the Preaching of Resurrection." Novum Testamentum 39 (1997): 21-39.

Cunha, Magali do Nascimento. "O conceito de religiosidade midiática como atualização do conceito de igreja eletrônica em tempos de cultura 'gospel."' Paper presented at the 25th Brazilian Congress of Science of Communication, Salvador, BA, September 4-5, 2002. http://intercom.org.br/papers/nacionais/2002/Congresso2002_Anais/2002_NP1cunha.pdf.

Cunha, Olívia Maria Gomes da. 'Fazendo a 'coisa certa:' Reggae, rastas e Pentecostais em Salvador.” 1991. Accessed March 17, 2018. http://www.anpocs.org.br/portal/publicacoes/rbcs_00_23/rbcs23_09.htm.

D’Antonio, Michael. Heaven on Earth: Dispatches from America`s Spiritual Frontier. New York: Crown, 1992.

Darwin, Charles. The Origin of Species: By Means of Natural Selection. New York: Cambridge University Press, 2009. 
Datafolha. "A fé do Brasil." 2016. Quoted in Diego Toledo, “Ateus 'saem do armário' religioso e reclamam de difícil aceitação no Brasil," January 21, 2017, https://noticias.uol.com.br/cotidiano/ultimas-noticias/2017/01/21/ateus-saem-do-armarioreligioso-e-reclamam-de-dificil-aceitacao-no-brasil.htm.

__ "Além da sua atual religião, você frequenta cultos ou serviços religiosos de alguma outra - de qual ou quais religiões?" 2017. http://media.folha.uol.com.br/datafolha/2013/05/02/religiao_03052007_1.pdf.

__. "Perfil e opinião dos evangélicos no Brasil.” December 7-8, 2016. http://www.pesquisas.org.br/wpcontent/uploads/2017/08/perfil_e_opiniao_dos_evangelicos_no_brasil.pdf.

Datesman, Maryanne Kearny, Joann Crandall, and Edward N. Kearny. American Ways: An Introduction to American Culture. White Plains, NY: Pearson Education, 2014.

Davie, Grace. "Believing without Belonging: Is This the Future of Religion in Britain?" Social Compass 37, no. 4 (1990): 455-69.

—. "Patterns of Religion in Western Europe: An Exceptional Case." In The Blackwell Companion to Sociology of Religion, edited by R. K. Fenn. Oxford: Blackwell, 2001.

—. "The Persistence of Institutional Religion in Modern Europe." In Peter Berger and the Study of Religion, edited by L. Woodhead. London: Routledge, 2001.

—. Religion in Britain Since 1945. Cambridge: Blackwell, 1994.

—. Religion in Modern Europe: A Memory Mutates. New York: Oxford University Press, 2000.

—. The Sociology of Religion. Los Angeles: SAGE, 2007.

Davis, Andrew Jackson. The Great Harmonia. Vol. 2. Boston: Mussey, 1852.

—. The Magic Staff: An Autobiography of Andrew Jackson Davis. New York: J. S. Brown, 1857.

Deccol, René. "Imigração internacional e mudança religiosa no Brasil.” USSP. 2001. http://www.abep.nepo.unicamp.br/iussp2001/cd/GT_Migr_Deccol_Text.pdf.

Dias, Arlindo Pereira. Domingão do Cristão: Estratégias de comunicação da Igreja Católica. São Paulo: Salesiana, 2001.

Dibelius, M. "Paul on the Areopagus." In Studies in the Acts of the Apostles. New York: Charles Scribner's Sons, 1956.

Dobbelaere, Karel. Secularization: An Analysis at Three Levels. New York: P.I.E.-Peter Lang, 2002. 
Donahue, Bill, and Russ Robinson. Edificando uma igreja de pequenos grupos. São Paulo: Editora Vida, 2003.

Donaldson, T. L. Judaism and the Gentiles: Patterns of Universalism. Waco: Baylor University Press, 2008.

Doss, Gordon R. Introduction to Adventist Mission. Silver Springs, MD: Institute of World Mission, General Conference of the Seventh-day Adventist Church, 2018.

_. "Too Far or Not Far Enough: Reaching out to Muslim People." Ministry, February 2005, 6-7.

Draper, Scott, Buster G. Smith, and Paul Froese. "Religious Pluralism and the Individual: The Effects and Meaning of Inter-Religious Contact." Journal of Social Science Studies 2, no. 1 (December 3, 2014): 234-49.

Durkheim, Emile. The Division of Labor in Society. New York: The Free Press, 1984.

—. The Elementary Forms of the Religious Life. New York: The Free Press, 1912.

_. Professional Ethics and Civic Morals. London: Routledge, 1992.

- The Rules of Sociological Method. New York: The Free Press, 1982.

—. Suicide: A Study in Sociology. New York: The Free Press, 1951.

Edinburgh 2010 Mission Conference. "Theme Three: Mission and Postmodernities.” In Edinburgh 2010 II - Witnessing to Christ Today.

http://www.edinburgh2010.org/en/study-themes/main-study-themes/mission-andpostmodernitiesccc9.pdf.

Ehrenberg, Ronald G. "Household Allocation of Time and Religiosity: Replication and Extension." Journal of Political Economy 85, no. 2 (1977): 415-23.

Elliston, Edgar J. Introduction to Missiological Research Design. Pasadena, CA: William Carey Library, 2011.

Engelsviken, Tormod. "Spiritual Conflict: A Challenge for the Church in the West with a View to Future." In Paradigm Shifts in Christian Witness: Insights from Anthropology, Communication, and Spiritual Power, edited by Charles E. Van Engen, Darrel Whiteman, and J. Dudley Woodberry, 116-25. Maryknoll, NY: Orbis Books, 2008.

Engen, Charles V. "Reflecting Theologically About Resistant." In Reaching the Resistant: Barriers and Bridges for Mission, edited by Dudley Woodberry, 22-78. Pasadena, CA: William Carey Library, 1998.

Erickson, Millard J. Truth or Consequences: The Promise and Perils of Postmodernism. Downers Grove, IL: Intervarsity Press, 2001. 
Feldman, Louis H. Jew and Gentile in the Ancient World: Attitudes and Interactions from Alexander to Justinian. Princeton: Princeton University Press, 1993.

Fernandes, Silvia Regina Alves. "A (re)construção da indentidade religiosa inclui dupla ou tripla pertença.” IHU Online. July 7, 2012. http://www.ihu.unisinos.br/entrevistas.

- Novas formas de crer: Católicos, evangélicos e sem religião nas cidades. São Paulo: CERIS-Promocat, 2009.

—. "Renovação carismática e o demônio: Notas do monitoramento da Revista Jesus Vive e é o Senhor.” Mneme-Revista de Humanidades 3, no. 6 (November 2002): 1-16.

. "Review of Igreja in concert: padres cantores, mídia e marketing, by André Ricardo de Souza. Centro de Estatística Religiosa e Investigações Sociais - Brasil.” Horizontes Antropológicos 12, no. 25 (January/June 2006): 311-15.

—_. "Sem religião: A identidade pela falta?” In Mudança de religião no Brasil desenvolvendo sentidos e motivações, edited by Silvia Regina Alves Fernandes, 107-18. São Paulo: Palavra e Prece, 2006.

— . "Trajetórias religiosas de jovens sem religião - algumas implicações para o debate sobre desinstitucionalização.” Interseções 20, no. 2 (2018): 369-87. https://doi.org/10.12957/irei.2018.39029.

Finke, Roger, and Rodney Stark. The Churching of America 1776-2005: Winners and Losers in Our Religious Economy. New Brunswick, NJ: Rutgers University Press, 2005.

Flosi, Fabio S. "'Father Landell de Moura-Radio Broadcasting Pioneer." Philatelia Chimica et Physica 34, no. 1 (2012): 18-26.

Fore, William F. “The Electronic Church.” Ministry, January 1979, 4-7.

Fox, Judith. "Secularization." In Routledge Companion to the Study of Religion, edited by John R. Hinnells, 306-22. New York: Routledge, 2010.

France, R. T. The Gospel of Matthew. The New International Commentary on the New Testament. Grand Rapids, MI: Eerdmans, 2007.

French, Rebecca. "Shopping for Religion: The Change in Everyday Religious Practice and Its Importance to the Law." Buffalo Law Review 127 (2003): 133-36.

Freud, Sigmund. The Future of an Illusion. New York: W. W. Norton, 1961.

. Moses and Monotheism. Great Britain: The Hogarth Press and The Institute of PsychoAnalysis, 1939.

. O Futuro de Uma Ilusão. Porto Alegre, RS: L\&PM Editores, 2010. 
Frigerio, Alejandro. "O paradigma da escolha racional: Mercado regulado e pluralismo religioso." Tempo Social 20, no. 2 (November 2008): 17-39.

Fritzsche, Peter, ed. Nietzsche and the Death of God. Long Grove, IL: Waveland Press, 2007.

Fuller, Robert C. Spiritual, But Not Religious: Understanding Unchurched America. New York: Oxford University Press, 2001.

Fundação Perseu Abramo. "Percepções e valores políticos nas periferias de São Paulo." Pesquisas de percepção social e opinião pública. April 5, 2017. Accessed February 10, 2020. https://fpabramo.org.br/publicacoes/publicacao/percepcoes-e-valores-politicos-nas periferias-de-sao-paulo/

Gallup. "Mississippi Retains Standing as Most Religious State.” February 8, 2017. https://news.gallup.com/poll/203747/mississippi-retains-standing-religiousstate.aspx? version=print.

—. "Religion." 2019. https://news.gallup.com/poll/1690/religion.aspx?version=print.

Gaventa, B. R. Acts. Abingdon New Testament Commentaries. Nashville: Abingdon, 2003.

Gedicks, Frederick Mark. "Spirituality, Fundamentalism, Liberty: Religion at the End of Modernity." DePaul Law Review 54, no. 1 (2005): 1197-1208.

General Conference of Seventh-day Adventists, Office of Archives and Statistics. Annual Statistical Reports. Silver Spring, MD: General Conference of Seventh-day Adventists, 2017.

Giddens, Anthony. As consequências da modernidade. São Paulo: Editora da Unesp, 1991.

Giordan, Giuseppe. "The Body between Religion and Spirituality.” Social Compass 56, no. 2 (2009): 226-36.

Glueck, Nelson. Khesed in the Bible. Cincinnati, OH: Hebrew Union College Press, 1967.

Godinho, Jones. “A individualização da espiritualidade como fruto da desfiliação religiosa: Os sem religião." Accessed November 15, 2018.

https://www.academia.edu/28152352/A_individualização_da_espiritualidade_como_frut o_da_desfiliação_religiosa_os_sem_religião.

Gomes, José Ozean. "Diversidade religiosa e mídia radiofônica: O uso das rádios comunitárias por instituições evangélicas no Brasil," 2020 Azusa-Revista de Estudos Pentecostais 4, no. 2 (2013): 187-91.

Gomes, Pedro Gilberto. "Processos midiáticos e construção de novas religiosidades: Dimensões históricas." Cadernos IHU 2, no. 8 (2004): 1-26. 
Gonçalves, Kleber de Oliveira. "A Critique of the Urban Mission of the Church in the Light of an Emerging Postmodern Condition.” PhD diss., Andrews University, 2005.

. "Witnessing to Christ in a Secular, Post-Christian, Postmodern Context." In Revisiting Postmodernism: An Old Debate on a New Era, edited by Bruce L. Bauer and Kleber de Oliveira Gonçalves, 119-41. Benton Harbor, MI: Patterson, 2012.

Governo do Brazil: Instituto Cidadania. "Projeto juventude: Documento de conclusão.” 2004. https://registrojuventude.files.wordpress.com/2011/02/dicas-projeto-juventude-final1.pdf.

Gow, Murray D. The Book of Ruth: Its Structure, Theme and Purpose. Edmonds, WA: Apollos Press, 1992.

Gray, John. I \& II Kings. 2nd ed. The Old Testament Library. Philadelphia: Westminster Press, 1970.

Groppo, Luís Antonio. "O funcionalismo e a tese da moratória social na análise das rebeldias juvenis." Estudos de Sociologia 14, no. 26 (2009): 37-50.

Grudem, Wayne. Teologia sistematica atual e exaustiva. Sao Paulo: Vida Nova, 2009.

Gulley, Norman R. Systematic Theology: Prolegomena. Berrien Springs, MI: Andrews University Press, 2003.

Hagner, Donald A. Matthew 14-28. Word Bible Commentary 33B. Dallas: Word, 1998.

Haim Hillel Ben-Sasson. "Galut.” In Encyclopaedia Judaica, 2nd ed., vol. 7. New York: Macmillan, 2007.

Hals, Ronald M. The Theology of the Book of Ruth. Philadelphia: Fortress Press, 1969.

Hasel, Gerard. "The Meaning of 'Let Us' in Gen. 1:26." Andrews University Seminary Studies 13 (1975): 58-66.

Heehs, Peter. Spirituality without God: A Global History of Thought and Practice. New York: Bloomsbury Academic, 2019.

Heelas, Paul. "The Spiritual Revolution: From Religion to Spirituality.” In Religions in the Modern World: Traditions and Transformations, edited by Linda Woodhead, Paul Fletcher, Hiroko Kawanami, and David Smith, 412-36. London: Routledge, 2005.

_ . "The Spiritual Revolution of Northern Europe: Personal Beliefs." Nordic Journal of Religion and Society 20, no. 1 (2007): 1-28.

Heelas, Paul, and Linda Woodhead. The Spiritual Revolution: Why Religion Is Giving Way to Spirituality. Oxford: Blackwell, 2007.

Hegel, G. W. F. The Philosophy of History. Buffalo, NY: Prometheus Books, 1991. 
Henry, Matthew. Matthew Henry's Concise Commentary on the Bible. Grand Rapids, MI: Christian Classics Ethereal Library, 1922.

Hiebert, Paul. Anthropological Insights for Missionaries. Grand Rapids, MI: Baker Academic, 1985.

—.Anthropological Reflexions on Missiological Issues. Grand Rapids, MI: Baker Books, 1994.

—. "Critical Contextualization." IBMR 11, no. 3 (1987): 10.

- The Gospel in Human Contexts: Anthropological Explorations for Contemporary Missions. Grand Rapids, MI: Baker Academic, 2009.

_. "Spiritual Warfare and Worldview." Direction: A Mennonite Brethren Forum 29, no. 2 (2000): 114-24.

- Transforming Worldview: An Anthropological Understanding of How People Change. Grand Rapids, MI: Baker Academic, 2008.

Hill, J. Arthur. Spiritualism, Its History, Phenomena and Doctrine. New York: George H. Doran, 1919.

Hirschle, Jochen. “'Secularization of Consciousness' or Alternative Opportunities? The Impact of Economic Growth on Religious Belief and Practice in 13 European Countries." Journal for the Scientific Study of Religion 52, no. 2 (2013): 410-24.

Hobbs, T. R. 2 Kings. Word Biblical Commentary 13. Grand Rapids, MI: Zondervan, 1986.

Hodgkin, A. M. Christ in All the Scriptures. Westwood, NJ: Barbour, 1989.

Horsfield, Peter G. Religious Television: The American Experience. New York: Longman, 1984.

Horton, Michael S. Pilgrim Theology: Core Doctrines for Christian Disciples. Grand Rapids, MI: Zondervan, 2012.

Hout, Michael, and Claude S. Fischer. "Explaining Why More Americans Have No Religious Preference: Political Backlash and Generational Succession, 1987-2012." Sociological Science 1 (2014): 423-47. https://www.sociologicalscience.com/download/volume\%201/october/SocSci_v1_423to4 47.pdf.

—. "Why More Americans Have No Religious Preference: Politics and Generations." American Sociological Review 67 (2002): 165-90.

Houtman, Dick, and Stef Aupers. "The Spiritual Turn and the Decline of Tradition: The Spread of Post-Christian Spirituality in 14 Western Countries, 1981-2000." Journal for the Scientific Study of Religion 46, no. 3 (2007): 305-20. 
Hubbard, Robert L. Jr. The Book of Ruth. Grand Rapids, MI: Eerdmans, 1943.

Hunter, George G. II. Church for the Unchurched. Nashville, TN: Abingdon Press, 1996.

Iannaccone, Laurence R. "The Consequences of Religious Market Structure: Adam Smith and the Economics of Religion." Sage Journals: Rationality and Society 3, no. 2 (April, 1991): 156-77.

_. "Deregulating Religion: The Economics of Church and State." Economic Inquiry 35 (April 1997): 350-64.

—. "Introduction to the Economics of Religion." Journal of Economic Literature 36 (September 1998): 1465-96.

—. "Religious Markets and the Economics of Religion." Social Compass 39, no. 1 (March 1992): 123-31.

Iannaccone, Laurence R., Roger Finke, and Rodney Stark. "Deregulating Religion: The Economics of Church and State.” Economic Inquiry 35 (April 1997): 351-52.

Instituto Brasileiro de Geografia e Estatística. "Características gerais da população, religião.” In Censos demográficos 1940-2010. Rio de Janeiro: IBGE.

- Censo demográfico 2010: Características gerais da população, religião e pessoas com deficiência. Rio de Janeiro: IBGE, 2012.

https://biblioteca.ibge.gov.br/visualizacao/periodicos/94/cd_2010_religiao_deficiencia.pd f

—. "População residente, por situação do domicilio e sexo, segundo a religião—Brasil, Tabela 1.1.2." Censo 2000. Accessed February 5, 2018.

— . "Religião: Distribuição relativa da população residente, por religião declarada." Brasil 1950/2000. Grafico 5.

——. "Religião: Séries históricas e estatísticas, população por religião; população presente e residente." Accessed February 13, 2018.

https://seriesestatisticas.ibge.gov.br/series.aspx?vcodigo=POP60.

Isaía, Artur Cesar. “A hierarquia Católica Brasileira e o passado Português.” In Portugal-Brasil no século XX: Sociedade, cultura e ideologia, edited by Christiane Marques Szesz et al., 233-53. Bauru: Edusc, 2003.

Isho `Dad of Merv. Horae Semiticae no. X: The Commentaries of Isho'Dad of Merv. Cambridge, UK: Cambridge University Press, 1913.

Jacob, Cesar Romero, Dora Rodrigues Hees, Philippe Waniez, and Violette Brustlein. Atlas da filiação religiosa e indicadores sociais no Brasil. Rio de Janeiro, RJ: Editora PUC-Rio, 2003. 
Jefferson, Thomas. "Jefferson`s Letter to the Danbury Baptists." Library of Congress. January 1, 1802. Accessed May 18, 2020. https://www.loc.gov/loc/lcib/9806/danpre.html.

Jenkins, Richard. "Disenchantment, Enchantment and Re-Enchantment: Max Weber at the Millennium.” Max Weber Studies 1, no. 1 (2000): 11-32. http://www.jstor.org/stable/24579711.

Jeremias, Joaquim. New Testament Theology. New York: Scribner`s, 1971.

Jones, Gwilym H. First and Second Kings. New Century Bible Commentary. Grand Rapids, MI: Eerdmans, 1984.

Jones, Robert P., and Daniel Cox. "Most Americans Believe Protests Make the Country Better; Support Decreases Dramatically among Whites if Protesters Are Identified as Black." PRRI. 2015. http://www.prri.org/research/survey-americans-believe-protests-makecountry-better-support-decreases-dramatically-protesters-identified-black/.

Josephus, Flavius. Antiquities. Edited by R. M. Pollard, J. Timmermann, J. di Gregorio, M. Laprade, and J.-F. Aubé-Pronce. The Latin Josephus Project. https://sites.google.com/site/latinjosephus/antiquities/.

—. Bellum Judaicum. Edited by E. Cardwell and R. M. Pollard. The Latin Josephus Project. https://sites.google.com/site/latinjosephus/bellum-judaicum.

Junior, James Muniz Marinho, and Maria Suely Cruz de Almeida. "O reconhecimento e dissolução de união estável no Brasil e o meio processual cabível nas hipóteses de companheiros com ou sem filho menor de idade.” Âmbito Jurídico. October 3, 2019. https://ambitojuridico.com.br/cadernos/direito-civil/o-reconhecimento-e-dissolucao-deuniao-estavel-no-brasil-e-o-meio-processual-cabivel-nas-hipoteses-de-companheiroscom-ou-sem-filho-menor-de-idade/.

Kaiser, Walter C. Jr. The Messiah in the Old Testament. Grand Rapids, MI: Zondervan, 1995.

—. Mission in the Old Testament: Israel as a Light to the Nations. Grand Rapids, MI: Baker Books, 2000.

_- "Salvation in the Old Testament: With Special Emphasis on the Object and Content of Personal Belief." Jian Dao: A Journal of Bible and Theology 2 (1994): 1-18.

—. Toward Rediscovering the Old Testament. Grand Rapids, MI: Zondervan, 1987.

Kant, Immanuel. Religion within the Bounds of Bare Reason. Indianapolis, IN: Hackett, 2009.

Karr, Eldyn. "Voice of Prophecy, Historic Adventist Media Outreach, Relocating to Colorado." Adventist Review. January 7, 2014. https://www.adventistreview.org/church-news/voiceof-prophecy,-historic-adventist-media-outreach,-relocating-to-colorado. 
Keener, Craig S. Acts: An Exegetical Commentary. Vol. 2. Grand Rapids, MI: Baker Academic, 2013.

- The Gospel of John: A Commentary. Vol. 1. Grand Rapids, MI: Baker Academic, 2003.

Kemper, Thomas. "The Missio Dei in Contemporary Context." International Bulletin of Missionary Research 38, no. 4 (2014): 188-90.

Kim, Sung Ik. "Proclamation in Cross-Cultural Context: Missiological Implications of the Book of Daniel." PhD diss., Andrews University, 2005.

Kittel, Gerhard, ed. Theologisches Wörterbuch zum Neuen Testament. Vol. 2. Stuttgart, Germany: W. Kohlhammer, 1935.

Klockner, Luciano, and Manolo Silveiro Cachafeiro, eds. Por que o Pe. Roberto Landell de Moura foi inovador? Conhecimento, fé e ciência. Porto Alegre, RS: Edipucrs, 2012.

Kovalik, Adam. "Efeito civil do casamento religioso no Brasil ontem e hoje." Âmbito Jurídico. May 31, 2007. https://ambitojuridico.com.br/edicoes/revista-41/efeito-civil-docasamento-religioso-no-brasil-ontem-e-hoje/.

Kraabel, A. T. "The Disappearance of the God-Fearers." In Diaspora Jews and Judaism: Essays in Honour of, and in Dialogue with, A. Thomas Kraabel, edited by J. Andrew Overman and Robert S. MacLennan, 119-30. Atlanta, GA: Scholars Press, 1992.

Kraft, Charles H. Christianity in Culture: A Study in Dynamic Biblical Theologizing in CrossCultural Perspective. Maryknoll, NY: Orbis, 1979.

- Christianity with Power: Your Worldview and Your Experience of the Supernatural. Ann Arbor, MI: Vine Books, 1989.

— . "Culture, Worldview and Contextualization." In Perspectives on the World Christian Movement, edited by Ralph D. Winter and Steven C. Hawthorne, 400-406. Pasadena, CA: William Carey Library, 2009.

Kuhn, Wagner. "Understanding Religious Syncretism in Brazil: Cases in Dual Allegiance with Implications for Adventist Mission." Revista Hermeneutica 7, no. 1 (2007): 19-37. http://www.seeradventista.com.br/ojs/index.php/hermeneutica/article/view/205/198.

LaCocque, André. Ruth: A Continental Commentary. Minneapolis, MN: Fortress Press, 2004.

Laertius, Diogenes. Lives of Eminent Philosophers, Volume 1. Translated by R. D. Hicks. Loeb Classical Library 184. Cambridge, MA: Harvard University Press, 1925.

Lambdin, Thomas O. Introduction to Biblical Hebrew. New York: Charles Scribner`s Sons, 1971. 
Le Beau, Bryan F. A History of Religion in America: From the End of the Civil War to the Twenty-First Century. New York: Routledge, 2018.

Lease, Gary. "The Caesarea Mithraeum: A Preliminary Announcement." Biblical Archaeologist 38, no. 1 (1975): 2-10.

Lee, Lois. "Non-Religion.” In The Oxford Handbook: The Study of Religion, edited by Michael Stausberg and Steven Engler, 84-94. Oxford: Oxford University Press, 2016.

Levinskaya, Irina. The Book of Acts in its First Century Setting: Diaspora Setting. Vol. 5. Grand Rapids, MI: Eerdmans, 1996.

Library of Congress. "The State Becomes the Church: Jefferson and Madison." June 4, 1998. https://loc.gov/exhibits/religion/rel06-2.html.

Lindório, Ronaldo. “A teologia bíblica da contextualização.” In Contextualização missionária: Desafios, questões e diretrizes, edited by Barbara Helen Burns, 6-36. São Paulo, SP: Vida Nova.

Locke, John. Two Treatises of Government and A Letter Concerning Toleration. New Haven, CT: Yale University Press, 2003.

Lowe, Chuck. Territorial Spirits and World Evangelisation? Borough Green, Kent, Great Britain: Mentor/OMF, 1998.

Luckmann, Thomas. Das Problem der Religion in der modernen Gesellschaft: Institution, Person und Weltanschauung. Freiburg: Rombach, 1963.

- The Invisible Religion: The Problem of Religion in Modern Society. New York: Macmillan, 1967.

Luiz, Ronaldo R. “A religiosidade dos sem religião.” Ciências Sociais e Religião 15, no. 19 (July/December 2013): 73-88. http://www.seer.ufrgs.br/CienciasSociaiseReligiao/article/view/44576.

Lumby, J. The Second Book of the Kings. Cambridge Bible for Schools and Colleges. Cambridge: Cambridge University, 1892.

MacLennan, R. S., and A. T. Kraabel. "The God-Fearers-A Literary and Theological Invention." In Diaspora Jews and Judaism: Essays in Honour of, and in Dialogue with, A. Thomas Kraabel, edited by J. Andrew Overman and Robert S. MacLennan, 131-43. Atlanta, GA: Scholars Press, 1992.

Maier, Walter A. III. "The Healing of Naaman in Missiological Perspective." Concordia Theological Quarterly 61 (1997): 177-96.

Mariano, Ricardo. "Efeitos da secularizaçao do estado, do pluralismo e do estado religioso sobre as igrejas Pentecostais." Civitas—Revista de Ciencias Sociais 3, no. 1 (2003): 112-25. 
https://www.researchgate.net/publication/228657209_Efeitos_da_secularizac_ao_do_Est ado_do_pluralismo_e_do_mercado_religioso_sobre_as_igrejas_pentecostais.

Mariz, Cecília. "Católicos da libertação, Católicos renovados e Neopentecostais - estudo de caso no Rio de Janeiro." Cadernos CERIS 1, no. 2 (2001): 17-42.

Mariz, Cecilia, and Maria das Dores Campos Machado. "Mudanças recentes no campo religioso Brasileiro." Antropolítica 5 (1998): 21-39.

Martelli, Stefano. A religião na sociedade pós-moderna. São Paulo: Paulinas, 1995.

Martin, David. A General Theory of Secularization. New York: Harper \& Row, 1979.

Marx, Karl. Capital: A Critique of Political Economy. Das Kapital 1. London: Penguin, 2004. . "Contribution to the Critique of Hegel's Philosophy of Law: Introduction." In Karl Marx, Frederick Engels: Collected Works. Vol. 3, 175-87. New York: International Publishers, 1843-4/1975.

Marx, Karl, and Frederick Engels. Manifesto of the Communist Party. Peking: Foreign Languages Press, 1970.

May, Stan. "Ugly Americans or Ambassadors of Christ?" Evangelical Missions Quarterly 41, no. 3 (2005): 346-52.

Merino, Stephen M. "Religious Diversity in a 'Christian Nation': The Effects of Theological Exclusivity and Interreligious Contact on the Acceptance of Religious Diversity." Journal for the Scientific Study of Religion 49, no. 2 (2010): 231-46.

Miller, Courtney. "Spiritual but Not Religious: Rethinking the Legal Definition of Religion." Virginia Law Review 102, no. 3 (2016): 833-94. http://www.jstor.org/stable/43923324.

Ministério da Saúde, Centro Brasileiro de Análises e Planejamento. "Pesquisa sobre o comportamento sexual da população Brasileira e percepções do HIV/AIDS, tabela 5." March 28, 2006. http://www.aids.gov.br/avalia4/home.htm.

Mobilidade Religiosa no Brasil. “Testemunho: Região episcopal sé.” February 4, 2006. http://www.regiaose.org.br/testem/06_fev_04.pdf.

Moltmann, Jürgen. The Church in the Power of the Spirit. New York: Harper and Row, 1977.

Moore, Rick D. God Saves: Lessons from the Elisha Stories. Journal for the Study of the Old Testament Supplement Series 95. Sheffield, England: JSOT, 1990.

Moreau, A. Scott. Contextualization in World Mission: Mapping and Assessing Evangelical Models. Grand Rapids, MI: Kregel, 2012. 
Moskala, Jiri. “A missão e a obra de Deus entre os gentios no Antigo Testamento." In Teologia e Metodologia da Missão, edited by Elias Brasil de Souza, 31-58. Cachoeira, BA: CePLiB (Seminário Adventista Latino-Americano de Teologia), 2011.

Müller, Ekkehardt. "Contextualization in the New Testament.” In Misión y Contextualizacion: Llevar el Mensaje Bíblico a un Mundo Multicultural, edited by Gerald A. Klingbeil, 17388. Libertador Samartín, Entre Rios, Argentina, 2005.

Neri, Marcelo C., ed. A economia das religiões: mudanças recentes. Rio de Janeiro: FGV/IBRE, CPS, 2007.

Neuman, Shoshana. "Religious Observance within the Human Capital Framework: Theory and Application.” Applied Economics 18, no. 11 (1986): 1193-1202.

Newbigin, Lesslie. The Gospel in a Pluralist Society. Grand Rapids, MI: Eerdmans, 1989.

Nicolini, Marcos Henrique de Oliveira. "Religião e cidade: A precariedade dos 'sem religião' como contestação da exclusão social em São Paulo.” Doctoral thesis, Universidade Metodista de São Paulo (UMESP), 2012.

Nietzsche, Friedrich. Beyond Good and Evil. New York: Vintage Books, 1966.

Normans, Jeremy. "Reginald Fessenden Conducts the First Audio Radio Broadcast of Entertainment and Music." Historyofinformation.com (blog). Accessed April 4, 2020. http://www.historyofinformation.com/detail.php?entryid=1639.

Norris, Pippa, and Inglehart, Ronald. Sacred and Secular: Religion and Politics Worldwide. New York: Cambridge University Press, 2011.

Novaes, Regina. “Os jovens sem religião: Ventos secularizastes, espirito de época e novos sincretismos. Notas preliminares." Scielo Analytics—Estudos Avançados 18, no. 52 (2004): 321-30. http://www.scielo.br/pdf/ea/v18n52/a20v1852.pdf.

Novaes, Regina, and Cecília Mello. "Jovens do Rio: Circuitos, crenças, acessos." Comunicações do ISER 21, no. 57 (2002): 30-37.

Oesterley, William Oscar Emil. The Jewish Background of the Christian Liturgy. Oxford: Clarendon, 1925.

Oliveira, Pedro Ribeiro. “A desafeição religiosa de jovens e adolescentes. Entrevista especial com Pedro Ribeiro de Oliveira.” Instituto Humanitas Unisinos. July 5, 2012. http://www.ihu.unisinos.br/entrevistas/511180-desafeicao-religiosa-esse-conceito-seriacentral-para-entendermos-os-sem-religiao-entrevista-especial-com-pedro-ribeiro-deoliveira.

Oosterwal, Gottfried. "The Process of Secularization." In Meeting the Secular Mind: Some Adventist Perspectives, edited by Humberto M. R. Rasi and Fritz Guy, 43-62. Berrien Springs, MI: Andrews University Press, 1985. 
Overman, J. A. "The God-Fearers: Some Neglected Features." In Diaspora Jews and Judaism: Essays in Honour of, and in Dialogue with, A. Thomas Kraabel, edited by J. Andrew Overman and Robert S. MacLennan, 145-52. Atlanta, GA: Scholars Press, 1992.

Paine, Thomas. Age of Reason. Grand Rapids, MI: Michigan Legal, 2014.

Panasiewicz, Roberlei. "Religião e Catolicismo em Belo Horizonte: Dados de pesquisa e leitura teológico-pastoral." Horizonte 10, no. 28 (2012): 1255-79.

Panasiewicz, Roberlei, Cláudio de Oliveira Ribeiro, and Gilbraz de Souza Aragão. "Espiritualidades contemporâneas, pluralidade religiosa e diálogo." In Anais do IV Congresso da ANPTECRE (Associação Nacional de Pós-graduação e Pesquisa em Teologia e Ciências da Religião), edited by Gilbraz Aragão and Newton Cabral, 987-88. São Paulo: ANPTECRE, 2013.

Pankau, Matthias, and Uwe Siemon-Netto. "The Other Iranian Revolution.” Christianity Today, July $2012,44-47$.

Parsons, Williams B., ed. Being Spiritual but Not Religious: Past, Present, Future. New York: Routledge, 2018.

Patriota, Karla Regina Macena Pereira. "O show da fé: a religião na sociedade do espetáculo: Um estudo sobre a Igreja Internacional da Graça de Deus e o entretenimento religioso brasileiro na esfera midiática.” Doctoral thesis, Universidade Federal de Pernambuco, 2008.

Patterson, Richard D., and Hermann J. Austel. 1 Kings-2 Kings. The Expositor`s Bible Commentary 3. Grand Rapids, MI: Zondervan, 2009.

Paulien, Jon. "The Post-Modern Acts of God." Scribd. November 18, 2004. https://www.scribd.com/document/7240142/The-Post-Modern-Acts-of-God.

Pausanias. Description of Greece. New York: G. P. Putnam's Sons, 1918.

Peursen, Cornelis A. Van. "Man, and Reality—the History of Human Thought." Student World no. 1 (1963): 13-21.

Pew Research Center. "5 Key Findings About Religiosity in the U.S.-And How It's Changing." November 3, 2015. https://www.pewresearch.org/fact-tank/2015/11/03/5-key-findingsabout-religiosity-in-the-u-s-and-how-its-changing/.

“About the Pew Internet \& American Life Project.” June 27, 2007. https://www.pewresearch.org/internet/2007/06/27/about-the-pew-internet-american-lifeproject/.

- "Brazil’s Changing Religious Landscape.” July 18, 2013.

https://www.pewforum.org/2013/07/18/brazils-changing-religious-landscape. 
. "Christians Remain World`s Largest Religious Group, but They Are Declining in Europe.” April 5, 2017. https://www.pewresearch.org/fact-tank/2017/04/05/christiansremain-worlds-largest-religious-group-but-they-are-declining-in-europe/

. "The Civic and Community Engagement of Religiously Active Americans." December 23, 2011. https://www.pewresearch.org/internet/2011/12/23/the-civic-and-communityengagement-of-religiously-active-americans/.

. “A Closer Look at America’s Rapidly Growing Religious Nones.” May 13, 2015. https://www.pewresearch.org/fact-tank/2015/05/13/a-closer-look-at-americas-rapidlygrowing-religious-nones/.

. "The Future of World Religions: Population Growth Projections, 2010-2050." April 2, 2015. https:/Www.pewforum.org/2015/04/02/religious-projections-2010-2050/.

. “The Global Religious Landscape.” Last modified December 18, 2012. Accessed February 28, 2018. http://www.pewforum.org/global-religious-landscape.aspx.

. "How Religious Is Your State.” February 29, 2016. https://www.pewresearch.org/facttank/2016/02/29/how-religious-is-your-state/?state=alabama.

- "In U.S., Decline of Christianity Continues at Rapid Pace: An Update on America's Changing Religious Landscape.” October 17, 2019. https://www.pewforum.org/2019/10/17/in-u-s-decline-of-christianity-continues-at-rapidpace/.

. "Interfaith Marriage Is Common in U.S., Particularly Among the Recently Wed." June 2, 2015. https://www.pewresearch.org/fact-tank/2015/06/02/interfaith-marriage/.

- “Little Voter Discomfort with Romney’s Mormon Religion.” July 26, 2012. https://www.pewforum.org/2012/07/26/2012-romney-mormonism-obamas-religion/

. "Millennials Increasingly Are Driving Growth of 'Nones." May 12, 2015. http://www.pewresearch.org/fact-tank/2015/05/12/millennials-increasingly-are-drivinggrowth-of-nones/.

. "The Modern News Consumer: News Attitudes and Practices in the Digital Era." July 7 , 2016. https://www.journalism.org/2016/07/07/the-modern-news-consumer/.

. "More Americans Now Say They're Spiritual but Not Religious." September 6, 2017. https://www.pewresearch.org/fact-tank/2017/09/06/more-americans-now-say-theyrespiritual-but-not-religious/.

. "More See ‘Too Much’ Religious Talk by Politicians.” March 23, 2012. https://www.pewforum.org/2012/03/21/more-see-too-much-religious-talk-by-politicians/.

. "Nones on the Rise." October 9, 2012. http://www.pewforum.org/2012/10/09/nones-onthe-rise/. 
_ "Q\&A: Why Millennials are Less Religious than Older Americans." January 8, 2016. http://www.pewresearch.org/fact-tank/2016/01/08/qa-why-millennials-are-less-religiousthan-older-americans/.

. "Religion Among the Millennials: Introduction and Overview." February 17, 2010. https://www.pewforum.org/2010/02/17/religion-among-the-millennials/.

_. "Religion in Electronic Media: One-in-Five Americans Share Their Faith Online." November 6, 2014. https://www.pewforum.org/2014/11/06/religion-and-electronicmedia/.

- "Religion in Latin America." November 13, 2014.

http://www.pewforum.org/2014/11/13/religion-in-latin-america/.

- "Religion in Latin America: Widespread Change in a Historically Catholic Region." November 1, 2014. https://www.pewforum.org/2014/11/13/religion-in-latin-america/.

—. "Religious Landscape Study: Adults Who Believe in God with Absolute Certainty Who Are Unaffiliated (Religious Nones)." Accessed March 30, 2020. https://www.pewforum.org/religious-landscape-study/religious-tradition/unaffiliatedreligious-nones/belief-in-god/believe-in-god-absolutely-certain/.

_. "Religious Landscape Study: Frequency of Prayer." Accessed May 11, 2020. https://www.pewforum.org/religious-landscape-study/frequency-of-prayer/.

. "Religious Landscape Study: Marital Status.” Accessed March 26, 2020. https://www.pewforum.org/religious-landscape-study/marital-status/.

. "Religious Nones Are Not Only Growing, They're Becoming More Secular." November 11, 2015. http://www.pewresearch.org/fact-tank/2015/11/11/religious-nones-are-notonly-growing-theyre-becoming-more-secular/.

- "Religiously Unaffiliated." December 18, 2012.

http://www.pewforum.org/2012/12/18/global-religious-landscape-unaffiliated/.

. "U.S. Public Becoming Less Religious." November 3, 2015.

https://www.pewforum.org/2015/11/03/u-s-public-becoming-less-religious/.

- "U.S. Public Has Warmest Feeling for Jews, Catholics and Evangelicals." July 16, 2014. https://www.pewforum.org/2014/07/16/how-americans-feel-about-religiousgroups/pf_14-07-16_interreligiousrelations_totalratings 1/.

“U.S. Religious Landscape Survey: Religious Beliefs and Practices," June 1, 2008. https://www.pewforum.org/2008/06/01/u-s-religious-landscape-survey-religious-beliefsand-practices/. 
- "Unaffiliated Population by Region, 2010 and 2050.” April 2, 2015. http://www.pewforum.org/2015/04/02/religiously-unaffiliated/pf_15-0402 projectionstables $82 \mathrm{~b} /$.

. "Values and American Exceptionalism." October 4, 2007.

https://www.pewresearch.org/global/2007/10/04/chapter-4-values-and-americanexceptionalism/.

. "When Americans Say They Believe in God, What Do They Mean?" April 25, 2018. http://www.pewforum.org/2018/04/25/when-americans-say-they-believe-in-god-what-dothey-mean/.

_ . "Why America's 'Nones' Don`t Identify with a Religion.” August 8, 2018. https://www.pewresearch.org/fact-tank/2018/08/08/why-americas-nones-dont-identifywith-a-religion/.

. "Why America's 'Nones’ Left Religion Behind.” October 24, 2016.

http://www.pewresearch.org/fact-tank/2016/08/24/why-americas-nones-left-religionbehind/.

. "With High Levels of Prayer, U.S. Is an Outlier Among Wealthy Nations." May 1, 2019. https://www.pewresearch.org/fact-tank/2019/05/01/with-high-levels-of-prayer-u-sis-an-outlier-among-wealthy-nations/.

. "World Publics Welcome Global Trade—But Not Immigration." October 4, 2007. https://www.pewresearch.org/global/2007/10/04/world-publics-welcome-global-tradebut-not-immigration/.

Philo. Legatio ad gaium. Translated by E. M. Smallwood. Leiden: E.J. Brill, 1961.

Philo. On Abraham. On Joseph. On Moses. Translated by F. H. Colson. Loeb Classical Library 289. Cambridge, MA: Harvard University Press, 1935.

Philostratus. The Life of Apollonius of Tyana: The Epistles of Apollonius and the Treatise of Eusebius. New York: G. P. Putnam`s Sons, 1921.

Pierucci, Antônio Flavio. "De olho na modernidade religiosa.” Tempo Social 2, no. 20 (2008): 916.

—_. "Secularização e declínio do Catolicismo." In Sociologia da religião e mudança social: Católicos, Protestantes e novos movimentos religiosos no Brasil, edited by Beatriz Muniz de Souza and Luiz Mauro Sá Martino. São Paulo: Paulus, 2004.

—_ "Secularização em Max Weber: da contemporânea serventia de voltarmos a acessar aquele velho sentido." Revista Brasileira de Ciências Sociais 13, no. 37 (1998): 43-73.

Pierucci, Antônio Flávio, and Reginaldo Prandi. A realidade social das religiões no Brasil. São Paulo: Editora Hucitec, 1996. 
Pocock, Michael. "Raising Questions About the Resistant." In Reaching the Resistant: Barriers and Bridges for Mission, edited by Dudley Woodberry, 3-10. Pasadena, CA: William Carey Library, 1998.

Poe, Harry L. Christian Witness in a Postmodern World. Nashville, TN: Abingdon, 2001.

Polhill, John B. Acts. New American Commentary 26. Nashville: Broadman, 1992.

Portela, Antônio Narcélio Machado. "Os primeiros Protestantes no Brasil colonial: Séculos XVI a XVII.” Monografias Brasil Escola: Historia. 2018. Accessed March 17, 2018. https://monografias.brasilescola.uol.com.br/historia/os-primeiros-protestantes-no-brasilcolonial-seculos-xvi-xvii.htm.

Powlison, David. Power Encounters: Reclaiming Spiritual Warfare. Grand Rapids, MI: Baker Books, 1995.

Prandi, R. “Converter indivíduos, mudar culturas.” Tempo Social 2, no. 20 (2008): 155-72.

Prata, Nair, Debora Cristina Lopez, and Wanir Campelo. "Panorama do rádio religioso no Brasil.” Intercom. Accessed April 23, 2010. http://www.intercom.org.br/papers/nacionais/2014/resumos/R9-0548-1.pdf.

Prates, Marco. “As capitais mais [e menos] evangélicas do Brasil.” Exame. September 13, 2016. https://exame.abril.com.br/brasil/as-capitais-mais-e-menos-evangelicas-do-brasil/.

Putnam, Robert D. Bowling Alone: The Collapse and Revival of American Community. New York: Simon \& Schuster, 2000.

Putnam, Robert D., and David E. Campbell. American Grace: How Religion Divides and Unites Us. New York: Simon \& Schuster, 2010.

Raines, John, ed. Marx on Religion. Philadelphia: Temple University Press, 2002.

“Religious Broadcasting.” Accessed November 17, 2020. https://transition.fcc.gov/osp/increport/INoC-11-Religious-Broadcasting.pdf.

Renders, H. "A experiência religiosa pós-moderna e o fenômeno da aceleração em comparação com as temporalidades pré-moderna e moderna." Revista Horizonte 37, no. 13 (2015): $428-45$.

Rex Humbard Foundation. http://www.rexhumbard.org.

Reynolds, J., and R. Tannenbaum. Jews and Godfearers at Aphrodisias: Greek Inscriptions with Commentary. Cambridge: Cambridge Philological Society, 1987.

Ribeiro, Flávio Augusto Senra. “Os sem religião por eles mesmos.” In A religião entre o espetáculo e a intimidade: VII Congresso Internacional em Ciências da Religião, edited 
by Alberto da Silva Moreira, Carolina Teles Lemos, Eduardo Gusmão de Quadros, and Rosângela da Silva Gomes, 51-58. Goiânia, GO: PUC Goiás, 2014.

Richardson, Don. Eternity in Their Hearts: Startling Evidence of Belief in the One True God in Hundreds of Cultures Throughout the World. Bloomington, MN: Bethany House, 2005. Kindle.

Ridderbos, Herman N. The Gospel of John: A Theological Commentary. Grand Rapids, MI: Eerdmans, 1997.

Riedinger, Edward A. "Landell de Moura, Father Roberto 1861-1928 Brazilian Wireless Pioneer.” In Encyclopedia of Radio. 3 vols. (2003).

Riesebrodt, Martin, and Mary Ellen Konieczny. "Sociology of Religion." In The Routledge Companion to the Study of Religion, edited by John Hinnels. New York: Routledge, 2010.

Rodrigues, Denise S. "Os sem religião e a crise do pertencimento institucional no Brasil: o caso Fluminense.” Doctoral thesis, Universidade Federal do Rio de Janeiro, 2009.

—_. "Religiosos sem igreja: Um mergulho na categoria censitária dos sem religião." REVER (December 2007): 31-56. http://www.pucsp.br/rever/rv4_2007/t_rodrigues.pdf.

Rodriguez, Ángel Manuel. “Oneness on the Church in Message and Mission: Its Ground.” In Message, Mission, and Unity of the Church, edited by Ángel Manuel Rodriguez, 243-59. Silver Springs, MD: Biblical Research Institute, 2013.

Roof, Wade Clark, ed. Contemporary American Religion. New York: Macmillan Reference USA, 2000.

—. A Generation of Seekers. New York: Harper Collins, 1993.

- Spiritual Marketplace: Baby Boomers and the Remaking of American Religion. Princeton, NJ: Princeton University Press, 1999.

Roop, Eugene F. Believers Church Bible Commentary: Ruth, Jonah, Esther. Scottdale, PA: Herald Press, 2002.

Rotterdan, Sandson. “A religião em xeque: Os sem religião no Brasil.” Revista Senso. September 7, 2017. https://revistasenso.com.br/2017/09/07/religiao-em-xeque-os-sem-religiao-nobrasil/.

Röwer, Basílio. Páginas de história Franciscana no Brasil. Petrópolis RJ: Editora Vozes, 1941.

Russo-Netzer, Pninit, and Ofra Mayseless. "Spiritual Identity outside Institutional Religion: A Phenomenological Exploration.” Identity 14, no. 1 (2014): 19-42. https://doi.org/10.1080/15283488.2013.858224. 
Sakenfeld, Katharine Doob. Faithfulness in Action: Loyalty in Biblical Perspective. Philadelphia: Fortress, 1985.

—. The Meaning of Hesed in the Hebrew Bible. Missoula, MT: Scholars Press, 1978.

_. Ruth. Louisville: Westminster John Knox Press, 1999.

Salvador Destination. "Origens da cultura popular e religiosidade em Salvador: Terra da magia e das folhas sagradas, abençoada por todos os santos." 2018.

https://salvadordestination.com/pagina/20/Origens-da-cultura-popular-e-da-religiosidadeem-Salvador.

Sampson, Philip, Vinay Samuel, and Chris Sugden. "Introduction.” In Faith and Modernity, edited by Philip Sampson, Vinay Samuel, and Chris Sugden. Oxford: Regnum, 1994.

Sanchez, Wagner Lopes. “(Des)encontro dos deuses: CNBB e pluralismo religioso no Brasil. Um debate a partir dos Encontros Intereclesiais de Base de CEB's (1992-1997)." Doctoral thesis, Pontifícia Universidade Católica de São Paulo, 2001.

Santana, Luther King de Andrade. "Religião e mercado: A mídia empresarial-religiosa." REVER, no. 1 (2005): 54-67.

Santos, Douglas Alessandro Souza. "Não-determinados? A pulverização evangélica e o problema metodológico do censo Brasileiro." Diversidade Religiosa 8, no. 1 (2018): 323.

Santos, Elói Correa. "Diversidade religiosa Brasileira e as quatro matrizes." ASSINTEC: Associação Inter-Religiosa de Educação, no. 38 (2016): 2-5.

Santos, Silvano Barbosa. "Revelation and Contextualization: A Seventh-day Adventist Approach.” Accessed September 2, 2020. https://www.academia.edu/11050512/Revelation_and_Contextualization_A_Seventh_day _Adventist_Approach.

Santos, Suzy dos, and Sérgio Capparelli. "Crescei e multiplicai-vos: a explosão religiosa na televisão brasileira." Intexto 2, no. 11 (2004): 1-24.

Saxegaard, Kristin Moen. Character Complexity in the Book of Ruth. Tübingen: Mohr Siebeck, 2010.

Schnabel, Eckhard J. Early Christian Mission: Jesus and the Twelve. Downers Grove, IL: InterVarsity Press, 2004.

Schürer, Emil, et al. The History of the Jewish People in the Age of Jesus Christ (175 B.C.-A.D. 135). Vol. 3. Edinburgh: T. \& T. Clark, 1973-87.

Schwarz, Christian A. God Is Indestructible: 12 Responses to the Relevance Crisis of Christianity. Emmelsbüll, Germany: NCD Media, 2020. Apple Books. 
_. God's Energy: Reclaiming a New Testament Reality. The Energy Trilogy 1. Emmelsbüll, Germany: NCD Media, 2020. Apple Books.

Seow, Choon L. A Grammar for Biblical Hebrew. Nashville: Abingdon Press, 1987.

Seventh-day Adventist College Presidents. Education: Sabbat School Bible Study Guide. Silver Springs, MD: Pacific Press, 2020.

Seversen, Beth. Not Done Yet: Reaching and Keeping Unchurched Emerging Adults. Downers Grove, IL: InterVarsity Press, 2020.

Sim, David C. "Gentiles, God-Fearers and Proselytes." In Attitudes to Gentiles in Ancient Judaism and Early Christianity, edited by David C. Sim and James S. McLaren, 9-42. New York: Bloomsbury T\&T Clark, 2013.

Simplilearn. "Understanding the Impacts of Social Media: Pros and Cons." September 22, 2020. https://www.simplilearn.com/real-impact-social-media-article.

Smedes, Lewis B., ed. Ministry and the Miraculous: A Case Study at Fuller Theological Seminary. Pasadena, CA: Fuller Theological Seminary, 1987.

Smith, Adam. An Inquiry into the Nature and Causes of the Wealth of Nations. New York: Modern Library, 1965.

Smith, Tom W., Michael Davern, Jeremy Freese, and Stephen Morgan. General Social Surveys, 1972-2018. Chicago: NORC, 2018. http://www.gssdataexplorer.norc.org.

Solsona, Gonçal Mayos. "El problema sujeto-objeto en Descartes, prisma de la modernidad." Pensamiento: Revista de investigación e información filosófica 49, no. 193/195 (JulySeptember 1993): 371-90. https://philpapers.org/rec/SOLEPS.

Southey, Robert. The Life of Wesley: And the Rise and Progress of Methodism. Vols. 1-2. New York: J. Seymour Print, 1820.

Souza, André Ricardo de. Igreja in concert: Padres cantores, mídia e marketing. São Paulo: Annablume e Fabesp, 2005.

Souza, Elias Brasil de. "Fundamentos bíblicos e teológicos do ministério de pequenos grupos." In Pequenos grupos, grandes soluções, edited by Milton Torres, 15-27. Guarulhos, SP: Parma, 2007.

Spencer, Herbert. The Principles of Sociology. New York: D. Appleton, 1886.

—. The Study of Sociology. London: Henry S, King, 1873.

—. A Theory of Religion. New York: Peter Lang, 1987.

Spies, F. W. “A abertura de um novo campo.” Revista Mensal 6, no. 2 (1911): 2-3. http://acervo.revistaadventista.com.br/capas.cpb. 
Stackhouse, John G. Jr. "Postmodern Evangelism: Sharing the Gospel as a Nonviolent Metanarrative." In Revisiting Postmodernism: An Old Debate on a New Era, edited by Bruce Bauer and Kleber Gonçalves, 31-41. Benton Harbor, MI: Patterson, 2013.

Stark, Rodney. “Must All Religions be Supernatural?” In The Social Impact of New Religious Movements, edited by Bryan Wilson. New York: Rose of Sharon Press, 1981.

—. "Secularization, RIP.” Sociology of Religion 60, no. 3 (1999): 249-73. https://academic.oup.com/socrel/article/60/3/249/1658084.

Stark, Rodney, and Laurence R. Iannaccone. "Supply-Side Reinterpretation of the 'Secularization' of Europe." Journal for the Scientific Study of Religion 33, no. 3 (1994): 230-52.

Stark, Rodney, and Roger Finke. Acts of Faith: Explaining the Human Side of Religion. Berkeley, CA: University of California Press, 2000.

Stark, Rodney, and William Sims Bainbridge. The Future of Religion. Los Angeles, CA: University of California Press, 1985.

—. "Networks of Faith: Interpersonal Bonds and Recruitment to Cults and Sects." American Journal of Sociology 85, no. 6 (May 1980): 1376-95. https://www.jstor.org/stable/2778383.

. "Of Churches, Sects, and Cults: Preliminary Concepts for a Theory of Religious Movements." Journal for the Scientific Study of Religion 18, no. 2 (June 1979): 117-31. https://www.jstor.org/stable/1385935.

—. A Theory of Religion. New York: Peter Lang, 1987.

Steil, Carlos Alberto. "Pluralismo, modernidade e tradição: Transformações do campo religioso." Ciências Sociais e Religião 3, no. 3 (2001): 115-29.

Stott, John R. W. The Message of Acts. The Bible Speaks Today. Downers Grove, IL: InterVarsity, 1990.

Strong, James. Strong `s Hebrew Dictionary. Albany, OR: Ages Software, 1999.

Sullivan, Dennis H. "Simultaneous Determination of Church Contributions and Church Attendance." Economic Inquiry 23, no. 2 (1985): 309-20.

Taylor, Charles. “Características e interfaces da secularização nos dias de hoje.” Instituto Humanistas Unisinos. May 2, 2013. http://www.ihu.unisinos.br/171-noticias2013/519716-charles-taylor-caracteristicas-e-interfaces-da-secularizacao-nos-dias-dehoje-.

—. The Ethics of Authenticity. Cambridge, MA: Harvard University Press, 2003. 
—. A Secular Age. Cambridge, MA: Belknap Press, 2007.

Teixeira, Faustino, and Renata Menezes, eds. Religiões em movimento: O censo de 2010. Petrópolis, RJ: Editora Vozes, 2013.

Text ex Machina. "New York Times Study: The Psychology of Sharing: Why Do People Share Online?" July 18, 2011. http://text-ex-machina.co.uk/blog/new-york-times-study.html.

Thomson-DeVeaux, Amelia. “Why Do Some Atheists Go to Church?” PRRI. December 9, 2011. https://www.prri.org/spotlight/why-do-some-atheists-go-to-church/.

Tippett, Alan R. Introduction to Missiology. Pasadena, CA: William Carrey Library, 1987.

_. People Movements in Southern Polynesia: Studies in the Dynamics of Church-Planting and Growth in Tahiti, New Zealand, Tonga, and Samoa. Chicago, IL: Moody Press, 1971.

—. Solomon Islands Christianity. London: Lutterworth, 1967.

Tompkins, Andrew J. "God's Mission to the 'Nations' and Hindus: Three Old Testament Narrative Models." Master's thesis, Andrews University, 2012.

_ . "A More Appropriate Mission to Hindus: Another Look at Syncretism in Light of the Naaman Narrative." Journal of Adventist Mission Studies 9, no. 1 (2013): 57-68.

Trebilco, P. Jewish Communities in Asia Minor. Cambridge: Cambridge University Press, 1991.

Tuffani, Maurício. “O verdadeiro inventor do radio.” Unespciência, November 2010, 50. https://www.unesp.br/aci/revista/ed14/ponto-critico.

Ulbrich, Holley, and Myles Wallace. "Church Attendance, Age, and Belief in the Afterlife: Some Additional Evidence." Atlantic Economic Journal 11, no. 2 (1983): 44-51.

Vattimo, Gianni. After Christianity. New York: Columbia University Press, 2002.

Vaus, David A. "Workforce Participation and Sex Differences in Church Attendance." Review of Religious Research 25, no. 3 (1984): 247-56.

Vieira, Jose Alves. "Os sem religião: Dados para estimular a reflexão sobre o fenômeno." Horizonte 13, no. 37 (January/March 2015): 605-12. http://dx.doi.org/10.5752/P.2175$5841.2015 \mathrm{v} 13 \mathrm{n} 37 \mathrm{p} 605$.

Vilhena, Tony Welliton da Silva. "Religião e novos movimentos sociais: A experiência organizativa do comitê inter-religioso do Pará." In Anais do IV Congresso da ANPTECRE (Associação Nacional de Pós-graduação e Pesquisa em Teologia e Ciências da Religião), edited by Gilbraz Aragão and Newton Cabral, 1009-29. São Paulo: ANPTECRE, 2013. 
Villasenor, Rafael Lopez. "Crise institucional: Os sem religião de religiosidade própria.” Revista Nures no. 17 (2011). https://revistas.pucsp.br/index.php/nures/article/view/5517.

Voice of Prophecy. "About the Voice of Prophecy-Equipping the World for Christ to Come." Accessed April 23, 2020. https://www.voiceofprophecy.com/about.

Voltaire. Treatise on Toleration. London: Penguin, 2016.

Wagner, C. Peter. Confronting the Powers: How the New Testament Church Experienced the Power of Strategic-Level Warfare. Venture, CA: Regal, 1996.

_. "Missiology and Spiritual Power." In Paradigm Shifts in Christian Witness: Insights from Anthropology, Communication, and Spiritual Power, edited by Charles E. Van Engen, Darrel Whiteman, and J. Dudley Woodberry, 91-97. Maryknoll, NY: Orbis Books, 2008.

—. "Territorial Spirits." In Wrestling with Dark Angels: Toward a Deeper Understanding of the Supernatural Forces in Spiritual Warfare, edited by C. Peter Wagner and E. F. Douglas Pennoyer. Ventura, CA: Regal Books, 1990.

- Warfare Prayer: How to Seek God's Power and Protection in the Battle to Build His Kingdom. Ventura, CA: Regal, 1992.

Wallace, Robert M. "Progress, Secularization and Modernity: The Löwith-Blumenberg Debate." New German Critique 22 (1981): 63-79.

Wallis, Roy. The Elementary Forms of the New Religious Life. London: Routledge \& Kegan Paul, 1984.

Wallis, Roy, and Steve Bruce. "Secularization: The Orthodox Model." In Religion and Modernization, edited by Steve Bruce. Oxford: Clarence Press, 1992.

Warner, Timothy M. "The Power Encounter and World Evangelization, Part 4: The Missionary on the Attack." 1988 Church Growth Lectures audiotaped by Fuller Seminary Media Services, October 27, 1988.

Weber, Max. El político y el Científico. Madri: Alianza, 2000.

—. Essays in Sociology. New York: Oxford University Press, 1958.

—. The Protestant Ethic and the Spirit of Capitalism. New York: Routledge, 2001.

- The Religion of China: Confucianism and Taoism. Glencoe, IL: The Free Press, 1951.

- The Religion of India: The Sociology of Hinduism and Buddhism. Glencoe, IL: The Free Press, 1958.

White, Ellen G. The Acts of the Apostles. Silver Spring, MD: Ellen G. White Estate, 2017. 
—. The Desire of Ages. Silver Spring, MD: Ellen G. White Estate, 2017.

—.Evangelism. Silver Spring, MD: Ellen G. White Estate, 2014.

—. The Great Controversy. Silver Spring, MD: Ellen G. White Estate, 2017.

—. The Ministry of Health and Healing. Silver Spring, MD: Ellen G. White Estate, 2017.

—. Prophets and Kings. Silver Spring, MD: Ellen G. White Estate, 2017.

White, James Emery. The Rise of the Nones: Understanding and Reaching the Religiously Unaffiliated. Grand Rapids, MI: Baker Books, 2014.

Williams, Margaret H. "The Jews and Godfearers Inscription from Aphrodisias: A Case of Patriarchal Interference in Early 3rd Century Caria?" Historia: Zeitschrift für alte Geschichte 41, no. 3 (1992): 297-310. http://www.jstor.org/stable/4436248.

Wilson, Bryan. “An Analysis of Sect Development." American Sociological Review 24, no. 1 (February 1959): 3-15.

_. "Aspects of Secularization in the West.” Japanese Journal of Religious Studies 3, no. 4 (December 1976): 259-76.

_. Contemporary Transformation of Religion. Oxford: Oxford University Press, 1976.

- "The Persistence of Sects." Diskus 2 (1993): 1-12.

. Religion in Secular Society. Oxford: Oxford University Press, 2016.

—. Religion in Sociological Perspective. Oxford: Oxford University Press, 1984.

_ . "Secularization: The Inherited Model." In The Sacred in a Secular Age: Toward Revision in the Scientific Study of Religion, edited by Phillip E. Hammond. Los Angeles: University of California Press, 1985.

—.The Social Dimensions of Sectarianism. Oxford: Oxford University Press, 1990.

Wimber, John. "Power Evangelism: Definitions and Directions." In Wrestling with Dark Angels: Toward a Deeper Understanding of the Supernatural Forces in Spiritual Warfare, edited by C. Peter Wagner and E. F. Douglas Pennoyer. Ventura, CA: Regal Books, 1990.

Witherington, Ben III. The Acts of the Apostles: A Socio-Rhetorical Commentary. Grand Rapids, MI: Eerdmans, 1988.

Wogu, Chigemezi-Nnadozie. "Constructs in Contexts: Models of Contextualizing Adventist Theology." International Bulletin of Mission Research 43, no. 8 (2018): 1-13. https://doi.org/10.1177\%2F2396939318754759. 
Wright, Christopher J. H. "Reading the Old Testament Missionally." In Reading the Bible Missionally, edited by Michael W. Goheen, 107-23. Grand Rapids, MI: Eerdmans, 2016.

Wright, N. T. "Reading the New Testament Missionally." In Reading the Bible Missionally, edited by Michael W. Goheen, 175-93. Grand Rapids, MI: Eerdmans, 2016.

Wuthnow, Robert. After the Baby Boomers: How Twenty-and Thirty-Somethings Are Shaping the Future of American Religion. Princeton, NJ: Princeton University Press, 2007.

Yancey, Philip. Church: Why Bother? My Personal Pilgrimage. Grand Rapids, MI: Zondervan, 1998.

Zepeda, José de Jesús Legorreta. "Secularização ou ressacralização? O debate sociológico contemporâneo sobre a teoria da secularização." Revista Brasileira de Ciências Sociais 25, no. 73 (June 2010): 129-41.

Zobel, Hans-Jurgen. "Khesed." In Theological Dictionary of the Old Testament, edited by Gerhard Johannes Botterweck and Helmer Ringgren. Vol. 5. Grand Rapids, MI:

Eerdmans, 1986. 